Tatiana de Oliveira Stoco

\title{
A PERSONALIDADE DO AGENTE NA FIXAÇÃO DA PENA
}

Dissertação de Mestrado

Orientador: Excelentíssimo Senhor Professor Titular Miguel Reale Júnior

Faculdade de Direito da Universidade de São Paulo

São Paulo

2013 
Para meus pais, com gratidão eterna por terem me dado tudo o que puderam e nada menos.

Para Danilo Growald, meu precioso presente, com todo meu amor e toda minha admiração. 


\section{AGRADECIMENTOS}

A entrega deste trabalho significa para mim a realização de um grande sonho que se iniciou ainda no ano de 2007, quando as primeiras ideias a respeito do tema me vieram à cabeça. Durante este processo de maturação de ideias e desenvolvimento do projeto e pesquisa, muitas pessoas estiveram presentes em meu caminho, cada uma colaborando, à sua maneira, para o que hoje apresento com orgulho e muita satisfação à Faculdade de Direito da Universidade de São Paulo.

Em primeiro lugar, agradeço a Mauro Moura Mohan por estar presente e atuante, sempre com muito carinho e dedicação, em boa parte de minha trajetória de vida. A ele devo a coragem de persistir na busca e realização do meu desejo.

A Renato Lúcio de Toledo Lima, amigo e irmão de alma, que me acompanhou por anos, incentivando meu trabalho e encorajando-me a sempre seguir meus sonhos.

Às amigas Helena Regina Lobo da Costa e Janaína Conceição Paschoal que participaram diretamente do meu ingresso à pós-graduação desta Faculdade. Por seu suporte, carinho e sempre muito valiosas dicas, serei eternamente grata.

Ao querido orientador Professor Miguel Reale Júnior, inspiração para todos que com ele convivem. Em primeiro lugar, agradeço pela amizade sincera, pelos debates engrandecedores, por ter sempre estado disponível para me atender durante a elaboração da minha pesquisa e por tantas vezes ter apaziguado as aflições que surgiram durante este percurso. Agradeço também pelos anos que trabalhamos juntos e pela valiosa convivência diária. Obrigada, Professor, pela oportunidade de tê-lo como amigo, colega de profissão e orientador.

Agradeço ao querido Alberto Zacharias Toron pelo incentivo e compreensão durante boa parte da elaboração desta dissertação e aos meus colegas do escritório Toron, Torihara e Szafir que igualmente torceram pelo meu sucesso nesta empreitada.

Ao meu pai, Rui Stoco, eterna inspiração e modelo de dedicação, trabalho e perseverança. À minha mãe querida, Maria de Lourdes de Oliveira Stoco, por sempre ter me incentivado a escrever e pelo carinho incondicional: agradeço e dedico este trabalho a vocês.

Por fim, agradeço ao meu querido Danilo de Paula Growald, por torcer tanto por mim e por colaborar com sua paciência, amor e incentivo para que eu pudesse alcançar meus objetivos.

A todos vocês, muito obrigada. 


\section{SUMÁRIO}

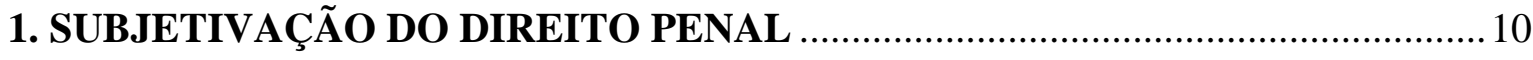

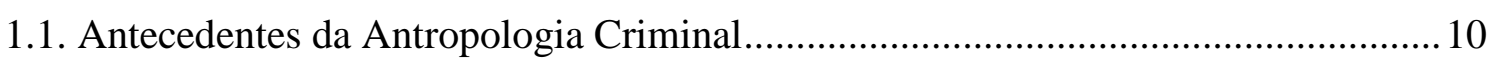

1.2. Criminologia Positivista, Antropologia Criminal e suas influências no Direito Penal 16

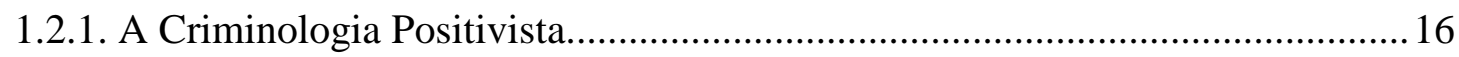

1.2.1.1. A Escola Criminológica Positivista italiana .............................................. 16

1.2.1.2. A Criminologia Positivista na França ......................................................220

1.2.1.3. A Criminologia Positivista na Espanha ...................................................22

1.2.2. O conceito de periculosidade e as medidas de segurança...................................25

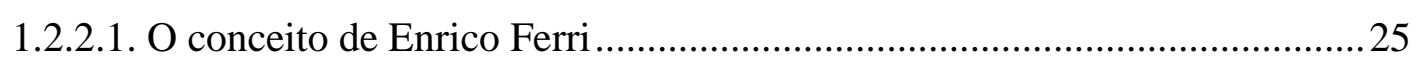

1.2.2.2. O conceito de Jiménez de Asúa .............................................................29

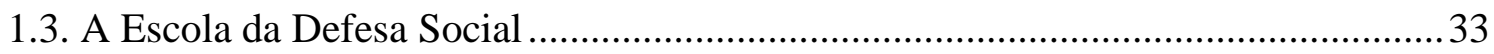

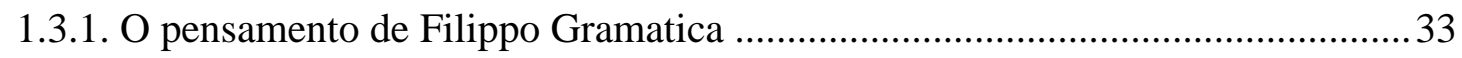

1.3.2. A Nova Defesa Social e o pensamento de Marc Ancel .....................................4 44

1.4. A influência do positivismo criminológico e da defesa social nas legislações e no

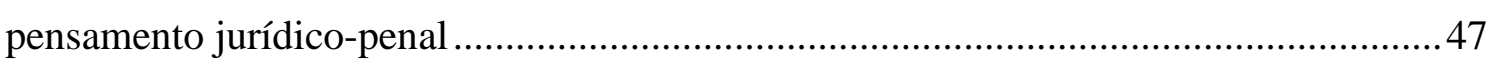

2. SUBJETIVAÇÃO DA LEGISLAÇÃO PENAL BRASILEIRA ..............................54

2.1. A influência do positivismo criminológico e das ideias de defesa social na legislação e no pensamento jurídico-penal brasileiros ...................................................54

2.2. Legislação penal brasileira. Escorço histórico ........................................................57

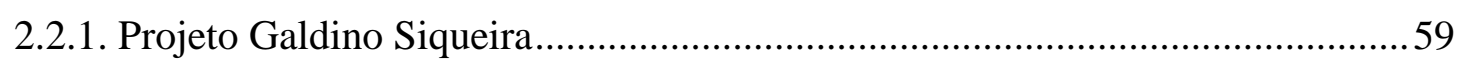

2.2.2. Projeto Virgílio de Sá Pereira ...........................................................................64

2.2.3. Projeto Alcântara Machado ..............................................................................6

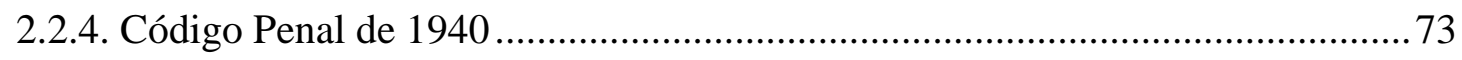

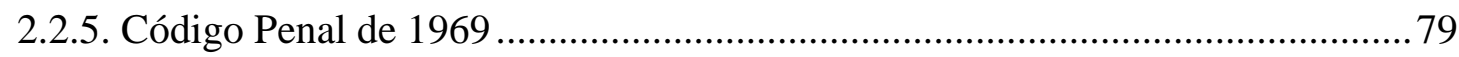

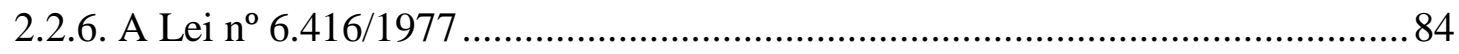

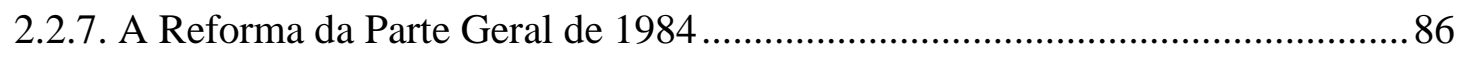

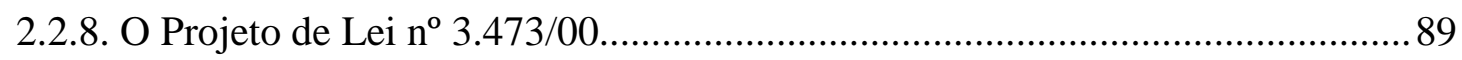

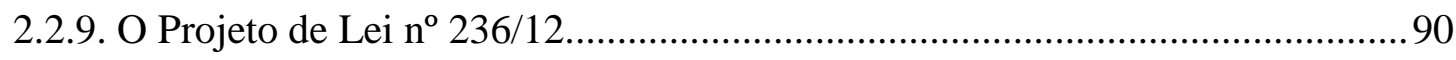




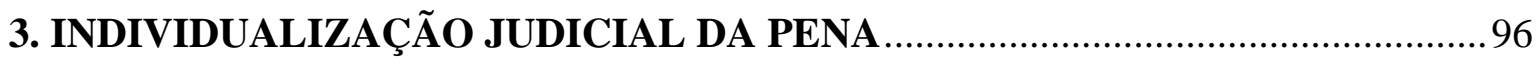

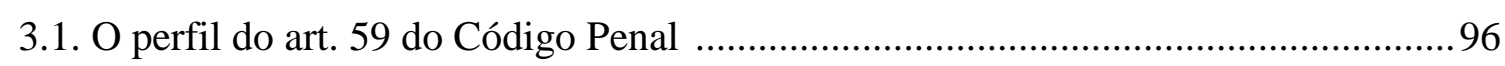

3.1.1. A subjetividade como característica marcante do modelo brasileiro ...............100

3.1.2. A individualização da pena no modelo brasileiro............................................ 104

3.2. Teorias sobre a individualização judicial da pena ................................................ 106

3.2.1 A necessidade de racionalização do processo de determinação judicial da pena 106

3.2.2. Alguns modelos teóricos do debate europeu .................................................109

3.2.2.1. Teoria da proporcionalidade pelo fato ou da pena proporcional ao fato ...109

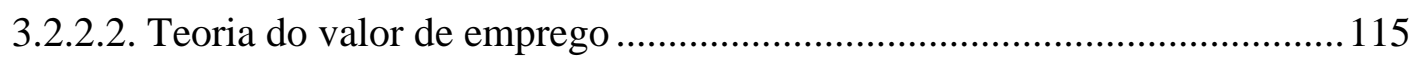

3.2.2.3. Teoria do espaço de jogo ou da margem de liberdade..............................119

3.2.2.4. Teoria da pena exata ou pontual .............................................................. 124

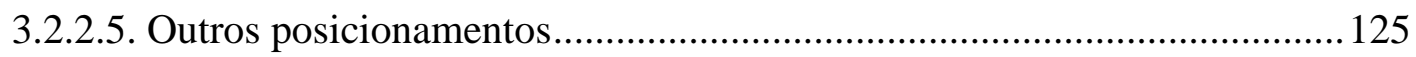

3.2.2.5.1. O sistema dogmático de determinação da pena de Silva Sánchez..... 125

3.2.2.5.2. O sistema normativo de determinação da pena de Patricia Ziffer .....127

3.2.2.5.3. A prevalência das finalidades de prevenção geral positiva ou a teoria da moldura de prevenção de Anabela Miranda Rodrigues ................................130

3.3. Critérios e princípios na graduação da pena .......................................................... 133

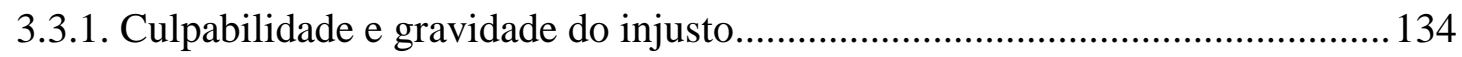

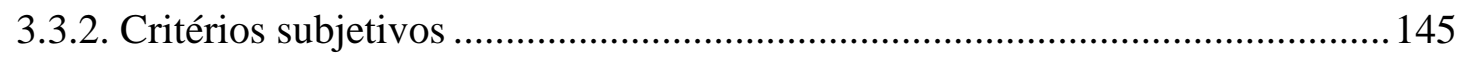

3.3.2.1. O papel dos critérios subjetivos na determinação da pena e sua ligação com

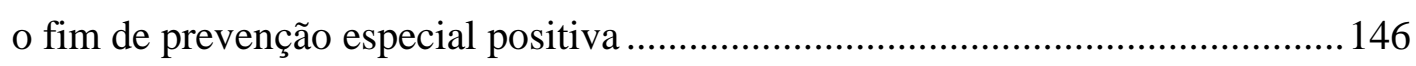

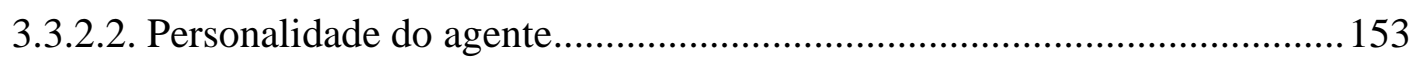

4. PERSONALIDADE DO AGENTE E FIXAÇÃO DA PENA .................................155

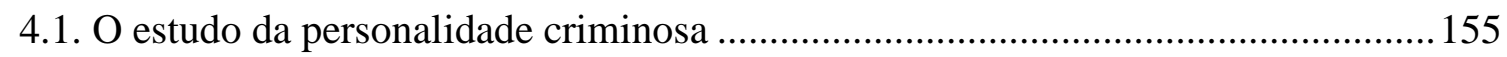

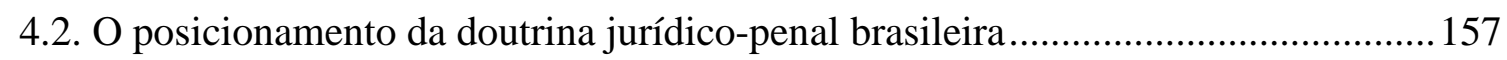

4.3. Acepções do termo e critérios de aferição segundo a jurisprudência brasileira ......168

4.3.1. Personalidade como sentimentos e valores morais negativos .........................169

4.3.2. Personalidade como expressão do modo de ser, do comportamento pessoal e da

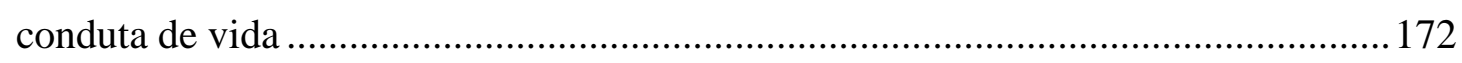

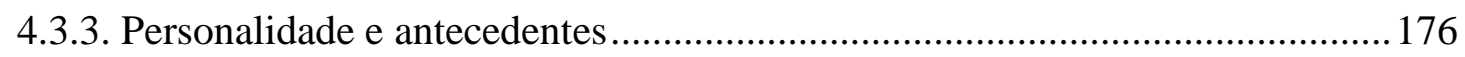


4.3.4. Outros critérios

4.4. Legitimidade da consideração da personalidade como critério judicial de individualização da pena...

4.5. “Condições pessoais do réu”: uma significação restritiva possível 188

4.5.1. O modelo espanhol 188

5. CONCLUSÕES 192

BIBLIOGRAFIA 194

RESUMO 203

ABSTRACT 205 


\section{INTRODUÇÃO}

A grande reviravolta no centro da Ciência Penal que se deu, sobretudo, em razão da influência da Criminologia positivista sobre o pensamento jurídico-penal e a produção legislativa de fins do século XIX em diante foi a subjetivação ${ }^{1}$ de seu objeto de estudo e foco de incidência da lei penal.

As ideias e conceitos que surgem com a Escola Positivista italiana, especialmente com a Antropologia Criminal e as medidas legislativas que resultaram do movimento denominado Defesa Social trouxeram, de forma irreversível, para dentro do pensamento jurídico-penal e das legislações penais um corte subjetivista que tem como foco principal não mais o crime, mas o criminoso. Essa é a mais significativa distinção que se vê desde a derrocada da Escola Clássica e o advento da Escola Positivista italiana com sua expansiva influência sobre as legislações penais dos países europeus e da América Latina.

As consequências desse giro em torno do centro da lei penal ainda são sentidas tanto no pensamento jurídico-penal, como nas legislações penais, e dentre elas estão os anteprojetos e os Códigos Penais brasileiros, incluindo-se o atualmente em vigor. São frutos dessa mudança de enfoque o surgimento da personalidade do agente como circunstância a ser sopesada na aplicação da pena e o conceito de periculosidade, adotado como critério de aplicação das medidas de segurança. Ambos os conceitos estão ainda presentes na nossa legislação penal atual, guardando quase a mesma acepção com que foram concebidos quando foram adotados pela nossa legislação.

\footnotetext{
${ }^{1}$ Neste trabalho, adotou-se como acepção para o termo "subjetivação" uma ênfase aos aspectos referidos à intimidade, ao psiquismo e à subjetividade do autor do delito. Nesse sentido, aqui, ele não se referirá às formas da conduta criminosa (dolo ou culpa). A opção por essa expressão, em detrimento do termo "Direito Penal de Autor", justifica-se, sobretudo, porque esse, usualmente, é aplicado para designar a teoria dos tipos de autor ou classificação de tipos de autor. A respeito dessa distinção, importa anotar a advertência de Víctor Gómez Martín: as vertentes das correntes sintomatológicas do delito estiveram apoiadas sobre uma base naturalista, fundamentadas em estudos empíricos do delinquente e orientadas no sentido da luta contra o delito a partir de resultados da estatística, da Psicologia e da Sociologia criminais como ciências empíricas pertencentes à Criminologia. Já o Direito Penal de autor em sentido estrito, especialmente desenvolvido na Alemanha nacional-socialista, não se trata de uma teoria criminológica, mas, sim, normativa e de natureza deontológica. (GOMEZ MARTíN, Victor. El derecho penal del autor del autor desde la visión criminológica tradicional hasta las actuales propuestas de Derecho penal de varias velocidades. Valencia: Tirant to Blanch, 2007, p. 115-116)
} 
É de imprescindível importância a análise da evolução e desenvolvimento desses conceitos para entender como o corte subjetivista ganhou corpo e influenciou os critérios de aplicação da pena. E é da análise da evolução do pensamento criminológico e das ideias que ele infiltrou na lei e no pensamento jurídico-penal que se irão extrair as mais fundamentais respostas para as questões que se pretendem ver solucionadas nesta investigação.

Mais importante do que atingir a precisa definição de personalidade para o Direito Penal, importará, neste trabalho, entender como e por que essa circunstância judicial foi eleita pela legislação penal brasileira como principal elemento a ser avaliado no momento da aplicação da pena. E, nesse sentido, é fundamental entender como se deu esse processo de subjetivação ao longo do tempo.

Assim, no primeiro capítulo, procurar-se-á demonstrar como o processo de subjetivação da lei e da doutrina penal surgiu no contexto da Ciência Positivista, induzido pela introdução de conceitos próprios das Ciências Médicas na Ciência Penal.

No segundo Capítulo, serão analisados os projetos e códigos penais brasileiros que contemplaram a personalidade do agente como critério de fixação da pena, analisando a ideologia própria da época, que serviu como plano de fundo para o desenvolvimento de um viés subjetivista de nossa Ciência jurídico-penal.

No terceiro capítulo, analisar-se-á a posição da personalidade do agente como critério de fixação da pena na atual legislação penal brasileira, seu perfil e principais características e deficiências. Também serão analisadas, ainda com menor profundidade, algumas das diversas teorias da determinação da pena que vêm sendo discutidas no cenário penal europeu, com o objetivo específico de oferecer aos critérios subjetivos um papel limitador do poder estatal, segundo um modelo de fixação da pena racional e que forneça critérios seguros para determinação da sanção.

No quarto capítulo, será analisado o conceito de personalidade para a doutrina e jurisprudência brasileiras, bem como seus critérios de aferição segundo as hipóteses concretas colhidas da jurisprudência nacional. Em seguida, serão levantadas as principais 
críticas ao critério da personalidade e será analisada a legitimidade de tal critério como circunstância judicial de determinação da pena. O capítulo se encerrará com uma proposta de aproximação da legislação brasileira em matéria de fixação da pena ao modelo adotado pelo Código Penal espanhol.

O último capítulo trará as principais conclusões do trabalho. 


\section{SUBJETIVAÇÃO DO DIREITO PENAL}

\subsection{Antecedentes da Antropologia Criminal}

O surgimento do pensamento criminológico inaugurado pela Escola Positivista italiana, atribuído pela maioria dos autores a Cesare Lombroso com a publicação de "L’Uomo delinquente”, contou com uma atmosfera social e científica propícia ao seu desenvolvimento.

A ingerência da ciência médico-psiquiátrica no controle social e no discurso punitivo, aliada ao método experimental das ciências naturais, forneceu a fórmula definitiva para o surgimento da Criminologia como ciência natural e experimentalista, que viria influenciar a Ciência Penal de forma decisiva.

Zafaroni afirma que, ao contrário do que sustentam os teóricos da Criminologia etiológica, a Criminologia não nasceu com os autores do final do século XIX. A Criminologia, com outro nome, mas como conhecimento acerca do mal criminalizado e criminalizável teria nascido com o próprio poder punitivo, com os demonólogos, denominados por ele como os primeiros criminólogos ${ }^{2}$.

Desde a Idade Clássica, as casas de internação para loucos foram transformando-se em espécies de prisões e o conhecimento médico-psiquiátrico passou a impor-se sobre o discurso jurídico, consagrando-se, ao longo do tempo, como discurso auxiliar da Ciência Penal $^{3}$.

\footnotetext{
${ }^{2}$ ZAFFARONI, Eugenio Raul. Criminología y Psiquiatria: el trauma del primer encuentro, p.70. Na mesma perspectiva, anotação de Marcos Cesar Alvarez: "Alguns autores, como Laurent Mucchielli, consideram que a história da Criminologia não se inicia no fim do século XIX com Lombroso, mas deita raízes mais profundas na história das Ciências Médicas na Europa desde o final do século XVIII. Assim, Lombroso seria mais propriamente um herdeiro, já que seu livro L'uomo delinquente condensaria os ensinamentos da Frenologia, da Antropologia, da Medicina Legal e do Alienismo dos dois primeiros terços do século XIX”. ALVAREZ, Marcos Cesar. Apontamentos para uma História da Criminologia no Brasil, p.132.

${ }^{3}$ Michael Foucault descreve como o internamento, em suas formas primitivas, funcionou como mecanismo social de eliminação espontânea dos "associais". Ele ressalta o papel de correição do internamento, na Idade Clássica, com o que "não é de surpreender que as casas de internamento tenham o aspecto de prisões, que as duas instituições sejam mesmo confundidas a ponto de dividir os loucos indistintamente entre umas $e$ outras”. FOUCAULT, Michael. A História da loucura na Idade Clássica, p. 116.
} 
Num relato detalhado e preciso sobre o tema, Gabriel Ignacio Anitua aponta para o fato de que a Medicina foi utilizada, no século XIX, como ferramenta para o funcionamento efetivo da sociedade e controle do comportamento humano. Ela justificava a diferença de tratamento dado pelo Estado para uns e outros indivíduos, especialmente a medicina alienista, unida à medicina social ou higienismo, que se dedicaria aos sujeitos portadores de anomalias ou imperfeições:

\begin{abstract}
“Asimismo, y de manera directamente relacionada con la modificación del individuo, también el carácter y el medio social podían ser cambiados. Y es sobre estos dos objetivos que actuaría la política guiada por criterios médicos y con la principal instituición de encierro del momento: el manicomio o asilo” ${ }^{4}$.
\end{abstract}

Enquanto a polícia servia como meio de prevenção, dentro do objetivo de profilaxia social, o manicômio ou asilo serviram como meio de prevenção destinado, em geral, aos sujeitos definidos como perigosos. Para ambos, o discurso médico servia de paradigma:

\footnotetext{
“No sería de extrañar que las nuevas medidas de represión, sin que exista un delito comprobado, fueran practicadas en hospitales y llevadas adelante con el ideal médico. Éstos, los médicos, podrían decir lo que es ‘peligroso’ para la sociedad" 5 .
}

Assinala o autor que o higienismo não contribuiu apenas à reorganização do espaço social das cidades e ao controle social, mas esteve sempre impregnado de uma pretensão moralizadora, inclusive no que respeita às ideias sobre a pena e a delinquência. No que diz respeito à Criminologia, essa prática levaria a teoria da pena a inclinar-se para o defensismo social utilitarista, que considera que quem delinque é uma célula enferma dentro do organismo social e, portanto, deve ser tratada e curada.

A importância desse fenômeno para o desenvolvimento do pensamento criminológico deu-se, principalmente, por meio da figura do "louco” ou "alienado"

\footnotetext{
${ }^{4}$ ANITUA, Gabriel Ignacio. Historia de los Pensamientos Criminologicos, p. 142.

${ }^{5}$ Idem, ibidem, p. 142.
} 
“Ésa sería la nueva denominación genérica del 'otro', hecha desde la ciencia modelo de la medicina que así aparecía actuando sobre el cuerpo individual, a la vez que sobre el cuerpo social. En el siglo XIX la forma de dirigir al Estado y a la sociedad se haría cada vez más médica, y la medicina seria cada vez más una forma de gobernar” 6 .

O ramo da Medicina que tomará com maior preocupação essa expressão será a Psiquiatria. O tratamento de loucos e delinquentes seria uma questão social. Nesse século, surgiria o termo "Psiquiatria” para tratar o que seria uma enfermidade da mente e tais estudos estariam diretamente relacionados com a Frenologia.

O triunfo dos médicos sobre a ciência jurídica, assinalado por Foucault ${ }^{7}$, deu-se com a imposição da lei francesa de 1838, que ampliava o campo médico dentro do jurídico ao regular a situação jurídica dos enfermos mentais ${ }^{8}$.

Anitua cita, dentre todos os médicos psiquiatras que se ocuparam do delito como enfermidade mental, o nome de Benoit Augustin Morel, que situava a delinquência junto à loucura e à enfermidade mental, dando origem à chamada "Psicopatologia Criminal”. Suas conclusões voltavam-se à convicção de que todo delito seria um fenómeno patológico causado pela interação de fatores biológicos e de fatores hereditários e sociológicoambientais ${ }^{9}$.

Seu “Tratado sobre a degeneração” teve significativa influência sobre as futuras ideias da Antropologia Criminal, sobretudo sobre a classificação de delinquentes de

\footnotetext{
${ }^{6}$ Idem, ibidem, p. 147.

${ }^{7}$ Na França, a questão da loucura na prática penal foi abordada no Código Penal de 1810 (art. 64) da seguinte forma: "não há crime nem delito, se o infrator estava em estado de demência no instante do ato". A possibilidade de invocar a loucura excluía, pois, a qualificação de um ato como crime. No entanto, conforme descreve Foucault, um fato curioso e decisivo deu outro destino à loucura: o Supremo Tribunal de Justiça, diante da imperiosidade de se decretar a improcedência judicial de um ato criminoso cometido em estado de loucura, passou a admitir a possibilidade da responsabilização do autor, ainda que em estado de demência. Como ressalta Foucault, "estava aí o ponto de partida de uma evolução que a jurisprudência e a própria legislação iam desencadear durante os 150 anos seguintes (...) a sentença que condena ou absolve implica uma apreciação de normalidade e uma prescrição técnica para uma normalização possível". FOUCAULT, Michael. Vigiar e Punir: nascimento da prisão. Petrópolis: Vozes, 2009, p. 24.

${ }^{8}$ Anitua destaca a influência de Jean Etienne Esquirol para a obtenção do indulto de Pierre Riviere, condenado por múltiplo parricídio, episódio que foi determinante para que os médicos editores da revista "Annales de Hygiène Publique et de Mèdicine Légale" lograssem a aprovação da lei de 1838. Historia de los Pensamientos Criminologicos, p, 148.

${ }^{9}$ Idem, ibidem, p. 149.
} 
Lombroso, que viria aparecer apenas na quarta edição de seu tratado sobre "O homem delinquente”. Ainda segundo o levantamento de Anitua,

\begin{abstract}
"Morel colocaba a la delincuencia junto a la locura y la enfermedad mental, y así daría origen a una 'psicopatología criminal' en la que ya estaban presentes conceptos como 'locura moral' o 'epilepsia'. Todo delito sería en definitiva un fenómeno patológico causado por la interacción de factores biológicos hereditarios y sociológicos ambientales. Esto evidentemente se relaciona con el positivismo criminológico, más aún en un libro suyo posterior, Sobre la formación de tipos, de 1864. Aquí se clasifican las distintas patologías en una 'antropología mórbida' que incluye en los criminólogos positivistas franceses el término mismo de 'degeneración', que explicaba para ellos la razón de la inferioridad del hombre delincuente" 10
\end{abstract}

O trabalho de Morel sobre as degenerescências da espécie humana consubstanciou a racionalidade dominante por mais de meio século no domínio do saber biológico, da Medicina mental e da própria Criminologia. Foi em torno do eixo degenerescência $\mathrm{x}$ perigosidade que se desenvolveram as diferentes teorias biológicas, psicológicas, sociológicas e antropológicas sobre o crime ${ }^{11}$.

Uma das primeiras aproximações claras da ciência médica com o campo criminológico, segundo o autor, seria a obra do americano Isaac Ray, de 1838, A jurisprudência médica da loucura. Para esse autor, o Direito sempre estaria atrás da Medicina, que estava dotada de um método indubitavelmente científico e, portanto, respeitável para o pensamento da época. Ela é que deveria determinar o critério de reprovabilidade e a imputabilidade em cada caso particular. Segundo a profunda crítica desse autor aos critérios jurídicos ou morais para determinar a capacidade de distinguir o bem do mal, a biologia se apresentava como o campo do qual surgiria a nova ciência criminológica.

Também o racismo do século XIX foi um importante antecedente da Criminologia como ciência. As preocupações com a salubridade, a sexualidade e, de forma geral, com o

\footnotetext{
${ }^{10}$ Idem, ibidem, loc. cit..

${ }^{11}$ Cf. MANITA, Celita. Personalidade criminal e perigosidade: da "perigosidade” do sujeito criminoso ao (s) perigos(s) de se tornar objeto duma “personalidade criminal”. in Revista do Ministério Público, p. 59.
} 
controle do ser humano que se produziria no século XIX deram sustentação à afirmação de uma inferioridade natural dos homens que não compartilhavam as características morais, religiosas e estéticas da burguesia.

Nesse processo de transformação e evolução da visão psiquiátrica, também foram importantes os trabalhos de Philipe Pinel, responsável por libertar das prisões e do convívio com os delinquentes aqueles que considerava enfermos mentais ${ }^{12}$. Essa mudança de orientação é fundamental para o advento de uma visão que passará a explicar a loucura fundamentada na suspeita de alienação do louco a respeito de si mesmo. Uma forma de determinismo ausente nos indivíduos normais, capazes de autodomínio e de autodisciplina $^{13}$.

Jorge de Figueiredo Dias reconhece que o surgimento da Criminologia Positivista italiana contou, à época, com esse conjunto de teorias precursoras que tentavam encontrar as causas do crime nos estigmas individuais do delinquente ${ }^{14}$, de onde se constata a estreita ligação entre os estudos médico-psiquiátricos e o tratamento da loucura com os trabalhos posteriores desenvolvidos por Lombroso:

“Aqui cabem logo as teorias dos fisionomistas, as quais pretenderam diferenciar
o criminoso a partir de traços específicos do rosto. Seguiu-se a escola
frenológica, que procurou os sinais identificadores do delinquente na
configuração exterior do crânio (...). Pertence ainda ao número das correntes
precursoras mais influentes aquela que se liga ao desenvolvimento científico da
psiquiatria. A partir do século XIX, começou, na verdade, a superar-se o quadro
tradicional das representações mitológicas, religiosas e supersticiosas sobre a
loucura. Esta passou a ser vista como uma doença mental, deixando de se
atribuir a intervenções demoníacas ou das bruxas, ou mesmo à influência dos
astros (concretamente da lua, como pretendia Paracelso). Em consequência, fez-
se sentir um forte movimento destinado a eliminar os tratamentos desumanos e

${ }^{12}$ Idem, ibidem, p. 148.

${ }^{13}$ Idem, ibidem, loc. cit..

${ }^{14}$ Nesse sentido também a anotação de Alfonso Serrano Maíllo: "Aparecem esforços dignos de menção, entre os quais devem se destacar o de Cubí i Soler. Esse autor cultivou a chamada Frenologia, que estudaria as manifestações da alma através do cérebro, mais concretamente, a alma humana tem algumas faculdades que são inatas, as quais se manifestam através de seu órgão, que é o cérebro, Este se encontra dividido em partes que correspondem a diversas funções. O importante deste ponto de vista positivo é que essas funções podem ser estudadas cientificamente atendendo ao tamanho e a forma do cérebro, que se reflete externamente no tamanho e forma do crânio". Introdução à Criminologia, p. 68-69. 
cruéis e a submeter os loucos a tratamento hospitalar. Paralelamente, procurou-se também explicar o crime a partir da ideia de doença mental, merecendo referência, neste contexto, os nomes de Ph. Pinel e J. Esquirol (Des maladis mentales, 1839), que atribuíam o crime a uma 'monomania', bem como o de Ferrarese com sua investigação de antropologia psiquiátrica (1843)”15.

O determinismo morfológico presente no pensamento desses médicos sentaria as bases da futura Antropologia Criminal. Nesse campo, na França, em 1827, foram publicadas as primeiras estatísticas modernas sobre a delinquência, atraindo a atenção de investigadores que se utilizavam dos métodos das ciências naturais, como Quetelet e Guerry, na França e de Mayhew, na Inglaterra ${ }^{16}$.

Os estudos médicos, frenológicos e psiquiátricos tiveram seu ponto de encontro com a Antropologia Criminal no estudo biopsicológico das causas e explicações biológicas da delinquência, ambas baseando-se em análises estatísticas e no método experimentalista das ciências naturais.

A Criminologia Positivista, inaugurada pela obra de Lombroso, surge, assim, imbuída num contexto em que a Frenologia e a ciência médica da época já alinhavavam ideias a respeito das explicações causais da delinquência. Aliadas a esse fator, as chamadas ciências naturais encontravam-se em franco desenvolvimento, fundadas no método empírico característico do final do século $\mathrm{XIX}^{17}$.

\footnotetext{
“Com o lastro anteriormente descrito, pode-se considerar a que a Criminologia positivista já havia nascido na Europa em meados do século XIX ou pouco antes. Contudo, sua consolidação somente tem lugar no final do mesmo século, em 1872, com a obra de Lombroso e, em menor medida, com a de Ferri e Garofalo, o que se conhece como a escola positivista ou italiana”, ${ }^{\text {. }}$
}

\footnotetext{
${ }^{15}$ DIAS, Jorge de Figueiredo. Criminologia. O homem delinquente e a sociedade criminógena, p.13-14.

${ }^{16}$ MAÍILO, Alfonso Serrano. Op. cit., p. 69-70.

${ }^{17}$ Figueiredo Dias anota "Fazia-se sentir no domínio das ciências do Homem a atração da filosofia, da lógica e da metodologia próprias do positivismo, cujo êxito no domínio das ciências empíricas não parecia conhecer limites. Para tal, muito contribuíram as obras de Darwin (The Origen os Species, 1859, e Descent of Man, 1871) ao estabelecerem as relações de continuidade entre o plano da natureza e o do homem”. Op. cit., p. 11.

${ }^{18}$ MAÍlLO, Alfonso Serrano. Op. cit., p. 71.
} 
De outro lado, a Psiquiatria passou a exercer um papel de higienização social, que se consagrou, na maior parte dos países que foram mais diretamente influenciados pela Criminologia Positivista, pela adoção das medidas de segurança, baseadas no juízo de periculosidade $^{19}$.

Daí porque afirma Zaffaroni que "a Psiquiatria se converteu no discurso dominante na questão criminal, neutralizando todos os limites assinalados pelo direito penal iluminista e da modernidade” ${ }^{20}$.

\subsection{Criminologia Positivista, Antropologia Criminal e suas influências no Direito Penal}

\subsubsection{A Criminologia Positivista}

\subsubsection{A Escola Criminológica Positivista italiana}

Antes de fornecer um breve resumo sobre os principais postulados do positivismo criminológico, convém ressaltar que os maiores expoentes dessa Escola criminológica, na Itália, guardavam, entre si, diferenças substanciais ${ }^{21}$.

Figueiredo Dias ressalva que as divergências que muitas vezes geraram controvérsia entre eles próprios decorreram da diferença de caminhos percorridos pelo médico Cesare Lombroso e os homens públicos que foram Enrico Ferri e Rafael Garofalo.

Daí, segundo o professor português, “que ao primado atribuído por Lombroso ao fator antropológico, Ferri tenha contraposto o peso das condicionantes sociológicas, enquanto Garofalo pôs em relevo o elemento psicológico” 22.

\footnotetext{
${ }^{19}$ Ainda segundo Zaffaroni, "Uma ideia produto deste primeiro encontro entre a criminologia e a psiquiatria permanece ainda viva e com vigência nas leis, na jurisprudência e no periodismo: a perigosidade. É o recurso ideológico mais arbitrário com que carrega o direito penal ainda em nossos dias, como triste recordação do primeiro encontro”. Criminología y Psiquiatria: el trauma del primer encuentro, p.70.

${ }^{20}$ Idem, ibidem, p. 81.

${ }^{21}$ A respeito da Escola Positivista italiana, limitaremos nosso trabalho à análise das ideias difundidas pelos seus mais expoentes representantes: Cesare Lombroso, Enrico Ferri e Rafaele Garofalo. Para um estudo aprofundado sobre os trabalhos de outros criminólogos positivistas, ver a já mencionada obra de Gabriel Anitua, Historia de los pensamentos criminológicos.
} 
Entre todos eles, contudo, persistiu o núcleo fundamental do positivismo: o postulado determinista e a rejeição do livre arbítrio e dos seus pressupostos metafísicos ${ }^{23}$. Seu ponto de partida é uma contundente reação contra a Escola Clássica, sobretudo contra sua metodologia lógico-indutiva, contra o qual se opôs o recurso decidido pela aplicação do método científico ao estudo do delito e do delinquente ${ }^{24}$.

Além disso, pôs-se em relevo respostas a respeito das causas do crime e a importância da análise da personalidade do delinquente para esse fim $^{25}$. Assim, pode-se afirmar que, com o advento da denominada Escola Positivista italiana, a tônica muda do estudo do sistema legal para o estudo da pessoa do delinquente.

Lombroso foi responsável pela elaboração da teoria radical do delinquente nato, cuja tese central é a do atavismo: o criminoso atávico, exteriormente reconhecível, corresponderia a um homem menos civilizado que os seus contemporâneos. A obra “L’Uomo delinquente”, republicada e revista muitas vezes pelo autor, é considerada o marco do nascimento da Criminologia contemporânea.

Mas a visão etiológica de Lombroso a respeito das causas da criminalidade não se limitava ao fator hereditário. Afirmava que a criminalidade tem caráter marcadamente plurifatorial. As causas socioambientais do delito já vinham sendo afirmadas antes mesmo da publicação da obra de Lombroso que, no entanto, privilegiou o fator biológico até a terceira edição de “L'uomo delinquente” ${ }^{26}$.

A quarta edição da obra de Lombroso, inspirada em trabalhos de Frenologia precursores, apresentava uma tipologia de delinquentes, para os quais corresponderia um conjunto de causas específicas. Os tipos básicos de delinquentes, segundo a classificação

\footnotetext{
${ }^{22}$ Op. cit., p.15.

${ }^{23}$ Idem, ibidem, loc. cit..

${ }^{24}$ MAÍLLO, Alfonso Serrano. Op. cit., p.72.

${ }^{25}$ Teodolindo Castiglione ressaltava: "A Criminologia encontra-se com o homem para estudar, em todos os aspectos, sua personalidade. Ninguém ignora o grande relevo que, em Criminologia, é colocado o estudo da personalidade, e todos sabem qual o papel que, neste particular, desempenhou Lombroso, como reconheceu até o insuspeito padre Gemelli”. Lombroso perante a Criminologia contemporânea, p.195.

${ }^{26}$ MAÍlLO, Afonso. Op. cit., p. 72.
} 
de Lombroso, seriam: nato, louco, moral, epilético, de ímpeto ou paixão e delinquente ocasional $^{27}$.

Sua classificação tipológica da delinquência serviria de modelo para muitos outros autores que, posteriormente, viriam esboçar suas próprias classificações de tipos de criminosos.

Desses autores, Enrico Ferri, positivista italiano contemporâneo de Lombroso, foi quem conseguiu desenvolver ainda mais essa categorização. Segundo Gabriel Anitua, Ferri foi o divulgador da versão mais conhecida e elaborada do positivismo criminológico. Ele influenciou de forma decisiva a classificação de delinquentes que tornou famosa a Escola Positivista italiana: os delinquentes nato, louco, habitual, ocasional e passional.

Para Ferri, o delinquente é sempre um anormal. Por condições congênitas ou adquiridas, permanentes ou transitórias, por anormalidade morfológica ou biopsíquica ou por enfermidade, mas anormal sempre ${ }^{28}$. O delito, para ele, é um sintoma, um fato que revela a personalidade perigosa do indivíduo e a pena é uma repressão necessária para defender o organismo social contra o estado perigoso de alguns indivíduos.

Ferri trouxe para o estudo do crime os aspectos sociológicos, além dos dados empíricos da Biologia. Ademais, advertiu que o processo penal e todo o sistema penal deveriam atuar para conseguir, de forma objetiva, a defesa social contra aquele que está determinado a delinquir. Propôs substituir a clássica categoria da responsabilidade criminal pela responsabilidade social, uma vez que o delito não poderia ser imputado a um ato de livre vontade, mas a um comportamento individual concreto.

A reação lógica da sociedade, portanto, seria a de impedir que o ato viesse a ocorrer no futuro. Tal argumento serviria para justificar medidas de defesa social antes mesmo do comportamento delitivo e serviria de substrato teórico para os substitutivos penais (medidas de segurança) e medidas pré-delituais ${ }^{29}$. As medidas também tinham como

\footnotetext{
${ }^{27}$ Idem, ibidem, loc. cit..

${ }^{28}$ FERRI, Enrico. Principios de Derecho Criminal, p. 193.

${ }^{29}$ Cf. ANITUA, Gabriel Ignacio. Historias de los pensamientos criminológicos, p. 189.
} 
função incluir - e não apenas excluir - por meio do tratamento curativo ou reeducador, o que dependeria do tipo de autor e do tratamento considerado mais idôneo.

Rafaele Garofalo voltou-se à elaboração do conceito de um “delito natural”, em sua obra A Criminologia, de 1885. Para ele, o que justificava a defesa social era a luta contra seus “inimigos naturais".

O conceito do que denominava “delito natural” não se baseava num critério descritivo preciso. Os valores da sociedade europeia seriam o paradigma do comportamento humano. Todo comportamento que violasse os sentimentos de piedade e probidade seria considerado delito. Assim, os delinquentes seriam os inimigos naturais, aqueles que carecem desses sentimentos. E, contra eles, não haveria medida ressocializadora possível, razão pela qual se defendia a pena de morte aos incorrigíveis ${ }^{30}$.

\footnotetext{
“Al unir criterios de los psiquiatras e médicos del siglo XIX con los que eran propios de la ciencia jurídica logro aumentar el cariz represivo de unos y otros. Criticaba por tanto lo que llamaba benevolencia - o mala actuación médica y judicial - para reprimir y separar a los peligrosos de la gente proba y piedosa. Fue, así, el sostenedor de las más terribles ideas de inocuización como solución frente a tales enemigos peligrosos” ${ }^{31}$.
}

Garofalo foi responsável pela introdução, no campo criminológico, do conceito de “temibilidade”, ainda em 1878. Esse conceito foi posteriormente desenvolvido por Enrico Ferri, sob a denominação de "perigosidade”, critério que assumiu importantíssima função jurídica no século XX.

Sua obra alcançou êxito singular nas Américas, mas suas ideias, assim como as ideias mais originais de Ferri e Lombroso foram matizadas por vertentes ecléticas, mais moderadas, como a que se desenvolveu na França com os trabalhos da União Internacional de Direito Penal, sobretudo por Von Liszt.

\footnotetext{
${ }^{30}$ Idem, ibidem, p. 189-190.

${ }^{31}$ Idem, ibidem, p. 190.
} 
No entanto, os mais importantes pressupostos teóricos da Escola Positivista italiana fundamentaram políticas criminais durante todo o século XX.

Outros positivistas foram além da matéria estritamente penal para ingressar no ramo do que denominavam "estado perigoso". Esse estado, a maioria das vezes, se expressava por um modo de condução de vida (mendicância, prostituição, prática de jogos de azar, religiões não oficiais, toxicomania, etc.) ou por qualquer comportamento que não se adequasse ao então vigente modo de vida burguês ${ }^{32}$.

A ideia de uma "classe perigosa” de indivíduos e suas práticas voltadas à “má-vida" difundiu-se por inúmeros países e na obra de diversos autores como uma realidade de marginalização social. Sobre o estudo desse fenômeno, ocuparam-se, especialmente, os representantes do positivismo criminológico na França.

\subsubsection{A Criminologia Positivista na França}

Na França do final do século XIX, a Criminologia Positivista dedicou-se com maior ênfase ao aspecto social da delinquência. Essa tendência já se verificava nas reflexões médico-psiquiátricas e antropológicas do século anterior, que se manteriam, dali em diante, entre os médicos franceses. Assim, a principal diferença entre a Criminologia positivista francesa e a italiana residia no fato de o meio social, e não a herança genética, ser a verdadeira causa do homem delinquente, razão pela qual se denominou "Mesologia Criminal”, em vez de “Antropologia Criminal”, essa nova disciplina ${ }^{33}$.

Alexandre Lacassagne é apontado como fundador dessa Escola, com a publicação de $O$ homem criminal comparado ao homem primitivo, de 1882. O homem criminal de Lacassagne não o era por atavismo, mas por degeneração nos sentidos psiquiátrico e sociológico $^{34}$.

\footnotetext{
${ }^{32}$ Idem, ibidem, loc. cit.

${ }^{33}$ Idem, ibidem, p. 191

${ }^{34}$ Idem, ibidem, p. 192.
} 
A despeito das diferenças que os criminólogos franceses mantinham com relação aos italianos, em última instância, todos eles defendiam a defesa da sociedade contra os incorrigíveis.

A maioria desses criminólogos eram médicos. Ainda segundo o relato de Anitua, isso se deve à profunda influência deixada ao longo do século XIX pelas nascentes disciplinas que, dentro daquele ramo do saber, exerciam certa capacidade sobre as questões humanas: a Antropologia e a Psicopatologia:

“(...) en la psicopatología estaría uno de los polares de la resistencia del positivismo criminológico tras el traspié sufrido en los años siguientes a la Primera Guerra Mundial. Por otro lado, el término ‘degeneración’ será usado en abundancia por otros criminólogos positivistas. Incluso de forma mucho más peligrosa que los médicos citados, que se dedicarían más a la clasificación y a la estadística que a las proposiciones políticas o filosóficas” ${ }^{35}$.

A ideia da pena aplicada sobre a psicologia do indivíduo ou, mais especificamente, sobre sua personalidade, surge neste contexto. Raymond Saleilles (1855-1912), em sua obra $A$ individualização da pena, expôs o que seria o modelo de punição do século XX: para ele, a pena devia estar baseada na ideia de liberdade e responsabilidade, princípio da Escola Clássica, mas aplicada, sobretudo, tendo em conta a psicologia do indivíduo princípio da Escola Positivista. Essa era a união de ideias clássicas e positivistas denominada "neoclassicismo", e Saleilles foi um dos primeiros de inúmeros autores que reconheceria a insuficiência do Direito quando atua como ciência isolada da realidade ${ }^{36}$.

A União Internacional de Direito Penal, fundada em 1889, na França, por Franz Von Liszt ${ }^{37}$, Van Hamel e Adolphe Prins teve importante papel no debate e na profusão das principais teses da Criminologia Positivista, como se verá mais adiante.

${ }^{35}$ Idem, ibidem, p. 194-195.

${ }^{36}$ Idem, ibidem, p. 196.

${ }^{37}$ Franz Von Liszt influenciou profundamente o pensamento jurídico-penal alemão com seu "Programa de Marburgo”, na Universidade de Marburgo (1882), inaugurando a chamada Escola Moderna de Direito Penal. Ele classificou os delinquentes segundo seu grau de perigosidade (ocasionais, habituais corrigíveis e habituais incorrigíveis), contribuindo para a formulação de uma das mais importantes concepções sobre os fins da pena: a preventivo-especial. Também para Von Liszt, a pena deveria atuar sobre as distintas classes de delinquentes, de formas distintas: a intimidação para os criminosos ocasionais; a correção para os habituais corrigíveis e a inocuização aos habituais incorrigíveis. Sobre a classificação tripartida (ou teoria dos 


\subsubsection{A Criminologia Positivista na Espanha}

Na Espanha, o positivismo penal e criminológico teve uma curiosa e original expressão no chamado Correcionalismo, cujas raízes remontam ainda ao século XIX e cujo pensamento assentava-se na ideia de tratamento e melhoramento moral dos membros da sociedade e dos presos. Karl Roeder teria inaugurado a teoria do melhoramento ou do correcionalismo, disseminando suas ideias no último terço do século XIX.

Dentre os nomes mais expoentes da Escola Positivista espanhola, destaca-se Pedro Dorado Montero, catedrático da Universidade de Salamanca, cuja ideologia foi herdada do pensamento de Karl Krause.

Dorado Montero, a exemplo do pensamento dos demais representantes da Criminologia Positivista, parte do naturalismo científico para propor um moderno sistema de Direito Penal que, segundo afirma, já vinha ganhando corpo. Sua tese volta-se à eliminação da punição de delinquentes e ao emprego exclusivo de medidas de proteção ${ }^{38}$.

A exemplo do que — segundo afirma - já se vinha aplicando aos mendigos, débeis, loucos, enfermos e necessitados de toda classe, também aos delinquentes se deveria aplicar o tratamento tutelar. Aplicar-lhes a pena-castigo seria, a seu ver, "afligir o afligido”, “amontoar injustiça sobre injustiça”39.

O fundamento da tutela de tratamento de Dorado Montero possui um forte apelo humanista e de defesa das classes sociais menos favorecidas. Não apenas por um sentimento de solidariedade ou compaixão, mas também por um senso de fraternidade social, todos os homens deveriam tratar-se como membros de uma grande família. E, assim

tipos de autor) de Von Lizt e, ainda, sobre a evolução do chamado Direito Penal de autor na Alemanha, vide MARTÍN, Víctor Gómez. El derecho penal del autor desde la visión criminológica tradicional hasta las actuales propuestas de Derecho penal de varias velocidades. Valencia: Tirant to Blanch, 2007.

${ }^{38}$ Para Dorado Montero a sanção punitiva seria uma exigência do idealismo abstrato, que ele rechaçava, propondo medidas de tratamento terapêutico e profilático, propostas que estariam, por sua vez, diretamente ligadas ao que denomina "realismo filosófico", ou seja, à submissão dos fenômenos humanos e sociais à lei geral da causalidade natural. MONTERO, Dorado. Bases para un nuevo Derecho Penal, p. 8.

${ }^{39}$ Idem, ibidem, p. 9. 
como se procede no seio familiar, dos delinquentes se deveria cuidar amorosa e solicitamente, a fim de melhorá-los e convertê-los em elementos úteis à sociedade ${ }^{40}$.

Segundo sua concepção, todo delinquente é um indivíduo débil por ser estimado como perigoso para a vida social, de acordo com os valores de determinado círculo social. Assim, com respaldo em Lombroso e Ferri, defende o esforço para que se convertam aqueles delinquentes em “forças utilizáveis”, cooperadoras do bem estar social, por meio de aplicação de penas usuais com fins de intimidação, de coação psíquica, de prevenção especial, ou de correção, até o uso de procedimentos higiênicos, fisiológicos, ginásticos, dietéticos, pedagógicos, etc. ${ }^{41}$

Pugna por uma administração da justiça penal com função de saneamento social, higienização e profilaxia social. Os funcionários equivalentes aos magistrados criminais se assemelharão - segundo seu pretendido novo sistema penal - aos médicos higienistas. Essa medicina social dependerá, segundo ele, do exercício acertado da Medicina individual, do diagnóstico, prognóstico e tratamento. Para tudo isso, impõe-se que o "médico penal" adquira todo e qualquer conhecimento natural ${ }^{42}$ a respeito do estado do sujeito e das causas produtoras de tal estado ${ }^{43}$.

O tratamento penal, também no pensamento de Dorado Montero, encontrará na individualização da pena sua maior expressão. A determinação da pena somente pode ser realizada mediante um exame consciente do estado particular do "paciente" e do conjunto das condições de que ele mesmo é um resultado ${ }^{44}$.

Os antecedentes do réu servirão, nesse processo de determinação da pena, para inferir o menor ou maior temor de que adiante continuará com a mesma conduta, serão a expressão do seu estado particular ${ }^{45}$.

\footnotetext{
${ }^{40}$ Idem, ibidem, p. 9.

${ }^{41}$ Idem, ibidem, p. 64.

42 Servirão a este fim, segundo o autor, sobretudo, a Antropologia Criminal, a Psicologia Criminal e a Sociologia Criminal.

${ }^{43}$ Idem, ibidem, passim.

${ }^{44}$ Idem, ibidem, p. 77.

45 A exemplo dos partidários da teoria da perigosidade, que será tratada no item 1.2.2., Dorado Montero igualmente dispensa a prática do delito para a adoção de medidas "profiláticas e terapêuticas” contra o delinquente que demonstre ser perigoso em razão de seus antecedentes e de sua conduta anterior: "El médico
} 
A grande ênfase à subjetividade no pensamento do autor espanhol encontra-se na avaliação da intenção do agente. Adotando um posicionamento do delito como expressão do sintoma da personalidade do delinquente, Dorado Montero afirma que a intenção deixa de ser critério de punibilidade para constituir-se em sintoma de perigo ou delinquência provável futura. Os juízes penais, com seus estudos de psicologia geral e conhecimentos de psicologia criminal determinarão a disposição com que o delinquente tenha agido e, em vista de sua boa ou má intenção, farão seu prognóstico e determinarão o correspondente tratamento $^{46}$.

O positivismo criminológico expandiu-se largamente pela América Latina, sobretudo na Argentina, Colômbia, Cuba e, conforme se verá mais adiante, no Brasil, países onde se verificou uma influência direta do Positivismo criminológico sobre as legislações penais e penitenciárias, e não apenas na produção doutrinária

Na Argentina, Norberto Piñero destacou-se no ensino do positivismo criminológico na Universidade de Buenos Aires, logrando, com seu programa penal positivista alcançar hegemonia sobre a elite cultural de Buenos Aires. No mesmo ano em que publicou sua obra Problemas de la criminalidad, em 1888, foi criada a Sociedad de Antropología Jurídica, dentro da qual se destacou Luis Maria Drago. Sua conferência resultou na publicação Los hombres de presa, também de 1888, obra que o fez famoso inclusive na Itália. Drago compartilhava das ideias dos dois positivistas italianos a respeito do tratamento corretivo para os criminosos de ocasião, da eliminação parcial dos delinquentes profissionais e da eliminação absoluta ou perpétua dos incorrigíveis ${ }^{47}$.

Cuba, Peru e México também tiveram larga produção doutrinária e legislativa sob a influência do positivismo criminológico.

social no necessita, pues, esperar a que el delito se haya efectuado; bastarále con la amenaza de su probable comisión próxima y en este caso hará lo mismo que hace el médico individual: proceder como higienista, que es decir, como médico previsor”. Ibidem, p. 80.

${ }^{46}$ Idem, ibidem, loc. cit.

${ }^{47}$ Cf. ANITUA, Gabriel Ignacio. Op. cit., p. 201-202. 
Nos Estados Unidos, o positivismo criminológico já havia se instalado antes mesmo da publicação da obra de Lombroso naquele país, sobretudo na área dos estudos psiquiátricos e penitenciários. Richard Fouis Dugale, estudioso francês, desenvolveu sua investigação sobre hereditariedade entre delinquentes, ainda em 1877, nos Estados Unidos $^{48}$. O país também contava com administradores de instituições de formação positivista. A tradução das obras de Lombroso, Garofalo e Ferri e seu particular êxito na Inglaterra de fins do século XIX foram os principais fatores a impulsionar a disseminação do positivismo criminológico também nos EUA ${ }^{49}$.

\subsubsection{O conceito de periculosidade e as medidas de segurança}

\subsubsection{O conceito de Enrico Ferri}

Um dos principais conceitos que surgiu da produção ideológica do positivismo criminológico e exerceu importante influência na produção legislativa dos países que adotaram essa nova ideologia, em termos de Política Criminal, foi o conceito de periculosidade.

O conceito de temibilidade, inicialmente elaborado por Garofalo, foi criticado como falho e insuficiente por expressar uma mera impressão subjetiva, vindo a ser, posteriormente, substituído pelo critério da perigosidade de Ferri ${ }^{50}$. Para ele, a intuição empírica da capacidade para delinquir se constitui num critério teorético e num guia prático, tanto na avaliação de indícios, como na medida da pena.

Refere-se ao momento que precede, assim como o que se segue à consumação do delito, motivo pelo qual constitui um critério tanto de defesa preventiva, como de defesa

\footnotetext{
${ }^{48}$ Seu trabalho resultou na publicação Os Jukes: um estudo sobre delito, miséria, enfermidade e herança, que procurava demonstrar que, entre 1874 e 1875, muitos dos detidos na prisão de Nova York pertenciam a uma mesma família, comprovando sua tese de que a criminalidade constituía-se em herança genética, além de fruto da influência de maus hábitos e costumes.

${ }^{49}$ Idem, ibidem, passim.

${ }^{50}$ FERRI, Enrico. Principios de Derecho Criminal, p.267.
} 
repressiva. Essa intuição assumiu valor científico e função jurídica no ordenamento da justiça penal ${ }^{51}$.

Para a Escola Positivista, a perigosidade do delinquente é independente do perigo objetivo, que é inerente ao fato criminoso. Pode subsistir, inclusive, quando falte perigosidade ao próprio fato, como, no exemplo de Ferri, no caso da tentativa impossível em razão dos meios adotados. Disso resultaria a necessidade indubitável de uma sanção repressiva contra o sujeito ${ }^{52}$.

A perigosidade do delinquente constitui, portanto, o critério (subjetivo) fundamental que vai substituindo o critério clássico (objetivo) da entidade do delito ${ }^{53}$.

Ferri destaca que a perigosidade criminal, como critério com função jurídica, aplica-se apenas após o delito. Ou seja, a função jurídica da perigosidade não consiste em dar o fundamento da imputabilidade e responsabilidade penais, tampouco constitui a base da anormalidade fisiopsíquica do sujeito. Essa é um dos elementos de avaliação da perigosidade que, por sua vez, constitui o critério básico para a adaptação legal, judicial e executiva da sanção penal à pessoa do delinquente.

Mas a imputabilidade ou responsabilidade depende só do fato de que o homem vive em sociedade e, portanto, deve ser responsável pelas infrações da lei penal cometidas, já que a lei penal possui um império absoluto sobre todos, normais e anormais, mais ou menos perigosos. É o que ele denomina de responsabilidade legal ${ }^{54}$.

Ferri parte da ideia de que todos os delinquentes são perigosos

\footnotetext{
"Lo que sucede es que esta peligrosidad, que siempre existe, puede ser diversa: desde un máximum que exige la sanción eliminadora del consorcio civil, a un mínimum que puede hacer posible la condena condicional e incluso el perdón” ${ }^{\text {„5 }}$.
}

\footnotetext{
${ }^{51}$ Idem, ibidem, p.266.

${ }^{52}$ Idem, ibidem, p. 269.

${ }^{53}$ Idem, ibidem, p. 270.

${ }^{54}$ Idem, ibidem, p. 272.

${ }^{55}$ Idem, ibidem, p. 274.
} 
Ele critica a confusão que se via, em matéria de perigosidade, na interpretação de alguns criminalistas da época, fato que teria levado a União Internacional de Direito Penal e outros ecléticos a considerar o delito como fundamento da pena e a perigosidade como fundamento das medidas de segurança. Seu posicionamento, ao contrário, parte do fundamento de que todos os delinquentes são perigosos e, portanto, o problema criminal resume-se em avaliar o grau de perigo de cada delinquente somente pelo fato de haver cometido uma ação delitiva a que deve responder.

E, nesse sentido, preocupa-se em esclarecer a distinção entre perigosidade social (policia de segurança) e perigosidade criminal (justiça penal). A perigosidade social corresponde à polícia de segurança e independe que o sujeito tenha cometido ou não um delito. Do ponto de vista criminal, em contrário, a perigosidade criminal não aparece senão depois que o delito se tenha verificado ${ }^{56}$.

\footnotetext{
"Para la justicia penal la peligrosidad criminal consiste en haber cometido o intentado cometer un delito (...) solo esta posee una función jurídica en la justicia penal, pudiendo definirse con Grispini como ‘un estado' de antijuridicidad del sujeto que produce la consecuencia jurídica de que se aplique una sanción criminal" 57
}

$\mathrm{Na}$ ordem da defesa social preventiva, pode-se determinar o conceito de perigosidade por meio do "perigo de delito", e nela sim se distinguem os indivíduos perigosos e não perigosos:

"En orden a la defensa preventiva se distinguen los ciudadanos en peligrosos y
no peligrosos; en cambio, para la defensa represiva todos los delincuentes son
peligrosos, si bien en grado diverso. Respecto a la defensa preventiva existe una
peligrosidad social genérica; para la defensa represiva una peligrosidad criminal
específica. La peligrosidad social lleva consigo el peligro de delito: la
peligrosidad criminal, el peligro de reincidencia. Se dan, por tanto, una valuación
preventiva y otra represiva de la peligrosidad. En la policía de seguridad las
medidas de defensa preventiva son 'medidas de policía', no debiendo

${ }^{56}$ Idem, ibidem, p. 247.

${ }^{57}$ Idem, ibidem, p. 275. 
confundirse con las 'medidas de seguridad' post delictum de la defensa represiva” ${ }^{58}$.

Para a avaliação do grau de perigosidade, Ferri aponta a importância da classificação de delinquentes, uma vez que o grau ou intensidade da perigosidade varia em ordem decrescente na classificação, desde o máximo, na categoria dos delinquentes natos, ao mínimo, na classe dos delinquentes passionais, segundo a tendência ao delito e sua execução sejam o efeito, em primeiro termo, de fatores individuais, endógenos (condições físico-psíquicas) ou de fatores ambientais exógenos.

Ferri indica para a avaliação do grau, duração provável e tendência da perigosidade três critérios mensuradores de caráter geral: a gravidade do delito, os motivos determinantes e a personalidade do agente ${ }^{59}$. A respeito desse último critério, o autor italiano afirma que, nas leis em vigor, o que mais interessa à justiça penal é a personalidade do delinquente:

\footnotetext{
"Por esto es por lo que en la reforma de la ley punitiva debe dicha personalidad del sujeto ser colocada en primer plano, con un sistema de normas que den realidad al principio de la Escuela Positivista, a saber: adaptar la sanción del delito a la peligrosidad del delincuente" ${ }^{60}$.
}

Para tanto, reclamava que deveriam ser reguladas pela lei processual de modo sistemático e concreto a investigação e coleta processual de dados físico psíquicos, familiares e sociais, pelos quais se pudesse individualizar a perigosidade do processado.

\footnotetext{
${ }^{58}$ Idem, ibidem, p. 276. Em resumo, acerca da função jurídica da perigosidade, segundo a doutrina ferriana: 1- não serve para justificar a responsabilidade do delinquente, já que esta tem o próprio fundamento de fato e de direito só na ideia de que o homem, vivendo em sociedade, deve respeitar o mínimo de disciplina social assinalado pelas leis penais; 2- é função diversa segundo se trate de perigosidade social (e então, na polícia de segurança, justifica as medidas de caráter preventivo que se hão de adotar contra os sujeitos temíveis por sua conduta perigosa em si ou por outras razões) ou de perigosidade criminal (na justiça penal), em cujo caso sua única função jurídica consiste em conseguir a adaptação (na lei, na sentença e na execução) da sanção repressiva à personalidade do delinquente, em razão do delito cometido e em vista de sua readaptação à vida livre. Idem, ibidem, p. 284-285.

${ }^{59}$ Idem, ibidem, p. 286.

${ }^{60}$ Idem, ibidem, p. 304.
} 
Além disso, entendia que os métodos da Antropologia Criminal deveriam ser utilizados e sistematizados no ordenamento jurídico da defesa social (preventiva e repressiva) contra a delinquência:

\footnotetext{
"Por tanto, es en la personalidad del delincuente como individualidad biopsiquica y como ser que vive en sociedad, donde sistemáticamente se caracterizan los elementos analíticos de graduación de su peligrosidad, ofrecidos por la gravedad del delito y por los motivos determinantes. De donde resulta que las afirmaciones hasta ahora presentadas sobre la peligrosidad criminal hallarán su continuación y término en la solución del problema último, a saber: adaptación de la sanción represiva a la personalidad del delincuente por razón del delito cometido" ${ }^{61}$.
}

O conceito de periculosidade (ou “perigosidade”, segundo Ferri), cuja aferição depende da análise da personalidade do agente, a partir do advento da Escola Positiva italiana foi alçado a critério fundamental para aplicação e execução da lei penal, passando a servir de elemento justificador de medidas administrativas defensivas do Estado contra aqueles que apresentem determinado grau, real ou presumido, de perigosidade.

\subsubsection{O conceito de Jiménez de Asúa}

Na Espanha, Jiménez de Asúa foi grande defensor da teoria da perigosidade. Elaborou a sua teoria do estado perigoso que influenciou diretamente a doutrina e a legislação argentinas, além de penalistas brasileiros como Aníbal Bruno.

Impulsionando a ideia restrita de temibilidade do delinquente de Garofalo, Jiménez de Asúa deu amplitude ao conceito. Defendeu a aplicação das medidas de segurança em todos os casos de perigosidade pré-delitual, e das penas, quando o perigo se revele na

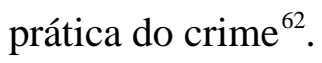

${ }^{61}$ Idem, ibidem, p. 308-309.

${ }^{62}$ Anote-se, contudo, que Jiménez de Asúa mudou seu posicionamento ao longo dos anos para reduzir a aplicabilidade das medidas de segurança para as hipóteses pós-delito. A respeito do tema, ver TOZZINI, Carlos A. Luis Jiménes de Asúa: un hombre sus circunstancias y su trascendencia - a propósito del estado peligroso. Revista de la Facultad de Derecho Universidad Complutense: estudios de derecho penal en homenaje al profesor Luis Jimenez de Asúa. Madrid, 1986. 
O chamado estado perigoso, na visão de Asúa, atendendo ao critério defensista, deve substituir o velho sistema punitivo clássico da responsabilidade e intencionalidade. O sistema por ele adotado se abstém de distinguir o problema filosófico da vontade livre e, sem negá-la nem afirmá-la, fixa-se unicamente no perigo que o delinquente supõe: seu estado perigoso ${ }^{63}$.

A consequência dessa concepção é separar a responsabilidade subjetiva, da qual afirma nada se poder saber, da responsabilidade objetiva e "tomar unicamente em conta o perigo que pode ameaçar a sociedade do exemplo e maneira de viver do delinquente ${ }^{\$ 4}$. Comprovado este estado perigoso, surge a necessidade de defender a comunidade social, seja o ato livre ou determinado, seja o delinquente um responsável ou um incapaz ${ }^{65}$.

Reconhecendo a dificuldade de se estabelecer um conceito único e preciso a respeito do estado perigoso - dificuldade que revela, apresentando as mais diversas conceituações entre os doutrinadores da época - Asúa apoia-se no conceito de pericolositá criminale, de Grispini:

\footnotetext{
"Do ponto de vista psíquico, portanto, a perigosidade criminal é um modo de ser de um sujeito, um atributo, uma qualidade de uma pessoa, e mais precisamente, é 'la condizione psichica di una persona in quanto probabile causa di reato'. Do ponto de vista jurídico, a perigosidade criminal é 'uno stato di antigiuridicitá di un soggeto, che há per conseguenza giuridica l'applicazione al medesino di una sanzione criminale ${ }^{\text {} 66}$.
}

Também para Asúa esse perigo é sempre subjetivo — estado perigoso do delinquente - e não um perigo objetivo, que emana de certos atos puníveis (tentativa, instigação, crimes de perigo comum).

Ressalta que o estado perigoso pode ser declarado antes do cometimento de algum delito e, por essa razão, têm lugar próprio as medidas de ordem preventiva e asseguradora. Seu posicionamento frente ao tema é extremista e avesso a posições mediadoras:

\footnotetext{
63 ASÚA, Jiménez. O Estado Perigoso, p. 37.

${ }^{64}$ Idem, ibidem, p. 42-43.

${ }^{65}$ Idem, ibidem, p. 45.

${ }^{66}$ Idem, ibidem, p. 61.
} 


\begin{abstract}
"Deve-se submeter a tratamento penal, assegurativo e tutelar, não porque o homem que cometeu uma transgressão seja livre no agir, não porque seja idêntico a si mesmo e semelhante aos demais, não porque seja normal, nem intimidável - como querem os que falam de imputabilidade dentro da doutrina determinista - senão porque constitui um perigo social, porque com seus actos revela sua temibilità ou estado perigoso" ${ }^{67}$.
\end{abstract}

Ampliando-se, assim, o conceito, ficaria resolvido o problema da imputabilidade diminuída dos enfermos mentais, posto que a intervenção penal estaria justificada apenas pela necessidade de defesa contra um ser perigoso, imputável ou não:

\footnotetext{
"A fórmula do estado perigoso resolve plenamente o problema da punibilidade dos delitos culposos. Com este conceito realista da temibilidade, se torna inútil entrar em polêmica estéril da causalidade eficiente. O estado perigoso pode dar fundamento sugestivo, seguro e eficaz à legítima defesa, ao estado de necessidade e a outras muitas causas que se se consideram como justificantes e impunes é por não ser temível o agente" ${ }^{\text {}}$.
}

Aceita a fórmula do estado perigoso, a pena, se não acabaria por desaparecer, seria, segundo ele, substituída pelas sanções de segurança. Sua natureza não será nem de expiação, nem de medida correcional, mas será um meio que participe do triplo aspecto intimidante, corretivo e inoculador, segundo os casos: uma pena adaptada ao caráter e à natureza do agente ${ }^{69}$.

O sujeito deverá estar submetido às medidas de segurança até quando dure seu estado perigoso. A sentença definida deveria ser substituída pela sentença indeterminada ${ }^{70}$. Além disso, a noção de estado perigoso não deveria restringir-se aos que tenham violado a lei. O perigo se manifesta, de fato, no crime, mas, segundo Asúa, não se deve esperar tanto para reconhecê-lo:

\footnotetext{
${ }^{67}$ Idem, ibidem, p. 116.

${ }^{68}$ Idem, ibidem, p. 117.

${ }^{69}$ Idem, ibidem, p. 119.

${ }^{70}$ Idem, ibidem, p. 120.
} 
"Às vezes o estado perigoso manifesta-se antes do crime, e então a sociedade deve defender-se. (...) Precisa-se de um passo a mais; quando se trate de indivíduos inclinados ao delito, quando, pela sua má conduta, seus antecedentes, etc, se possa inferir que vão violar a lei e perturbar a paz social, é necessário que o Estado atue com medidas preventivas e assecuratórias, ainda que se trate de homens normais" ${ }^{71}$.

Sobre as objeções que se apontavam contra a violação às garantias individuais diante de tal sistema, Asúa limitava-se a afirmar que qualquer receio à liberdade individual era desmedido, uma vez que a teoria da perigosidade tratava-se de uma defesa social “consciente de seu fim”. Preocupava-se mais com a necessidade de preparo e educação dos magistrados, para a declaração judicial do estado perigoso, do que com qualquer outra objeção de natureza garantista.

A ideia de periculosidade social inseriu-se no Código Rocco (1927, Itália) e inspirou diversas legislações penais de outros países. No Código Penal Italiano de 1930, as medidas de segurança surgem como medidas que se distinguem das penas "pelo seu pressuposto diverso que não é tanto, ou apenas não é sempre, o cometimento de um crime, mas sim a qualificação da pessoa como 'socialmente perigosa' pela probabilidade que cometa qualquer delito futuro (arts. 202-203)" 72 .

As medidas de segurança previstas no art. 205, do Código Penal Italiano de 1930 são, em substância, medidas de defesa social similares às medidas de prevenção distintas da pena e que pertencem "ao amplo e vasto espectro das medidas administrativas de polícia” "73, de caráter flagrantemente administrativo. Além de estarem previstas sob o título "Das medidas administrativas de segurança", têm como características principais a arbitrariedade e sua sucessiva revogabilidade.

Nos países socialistas, a periculosidade passou a ser a nota indicativa da necessidade da repressão penal. O Código Penal Russo de 1958 adotou a periculosidade como critério de tipicidade penal (art. $7^{\circ}$ ). No Projeto de Código Penal para Cuba, o art. 17

\footnotetext{
${ }^{71}$ Idem, ibidem, p. 121.

${ }^{72}$ FERRAJOLI, Luigi. Direito e Razão. Teoria do garantismo penal, p. 718.

${ }^{73}$ Idem, ibidem, p. 719.
} 
prescrevia: "são pessoas perigosas para os efeitos da lei penal aqueles que, sem cometer crimes (...) mostram uma extraordinária inaptidão moral, mental ou legal, que as torna propensas a delinquir ou socialmente temíveis”.

Com o respaldo do conceito de periculosidade social, o Direito Penal passou a tutelar as práticas que pudessem sugerir uma ideia de anormalidade ou de um perigo à ordem social - muito a exemplo do higienismo francês do século XIX —, sob a justificativa legitimadora da necessidade de defesa social. Isso abriu caminho não apenas para um autoritarismo sem precedentes e para o exercício de um poder de polícia que ultrapassa os limites da legalidade em matéria penal, mas também para um profundo subjetivismo que vai lhes servir de suporte ${ }^{74}$.

\subsection{A Escola da Defesa Social}

\subsubsection{O pensamento de Filippo Gramatica}

Ao longo do século XX, o termo “defesa social” admitiu diversas interpretações entre os mais diversos autores e entre os próprios adeptos do movimento da chamada Defesa Social.

Entre todas as acepções do termo, estava a ideia de que o conceito de defesa social conduz a um "humanismo judiciário" que tende a transformar a administração da justiça penal. Assim, seria possível conceber defesa social menos como uma doutrina objetiva e mais como um engajamento, a aceitação deliberada de certa orientação a ser impressa à reação anticriminal e à justiça penal, dentro do respeito à dignidade humana e com a

\footnotetext{
74 “É certo que a maior contribuição à introdução das medidas de segurança em nosso ordenamento, ou quanto menos a sua legitimação ideológica foi um legado da 'Escola Positiva', ou antropológica do direito penal que, como se viu, substituiu a categoria responsabilidade por aquela da periculosidade, e concebeu o crime como 'um sintoma' de patologia psicossomática, devendo enquanto tal ser tratado e prevenido mais do que reprimido, com medidas pedagógicas e terapêuticas destinadas a neutralizar as causas exógenas. Esta ambígua doutrina substancial, alimentada do progresso humanitário, foi recebida pelo legislador fascista, que a introduziu em um sistema penal duplamente vexatório, desamparado do princípio de estrita legalidade penal, e dos corolários conexos garantistas próprios do regime de penas, fundado decisivamente na personalidade do sujeito e na valoração da sua 'periculosidade social' constituindo, assim, um modelo do 'tipo normativo de autor'”, FERRAJOLI, Luigi. Op. cit., p. 718.
} 
preocupação de reconduzir ao convívio social aqueles a quem essa reação social atinja. Essa é a definição que lhe deu um de seus maiores representantes, Marc Ancel ${ }^{75}$.

Trata-se de um movimento marcado por um forte apelo humanista — ainda que tal afirmação possa soar absolutamente contraditória se se analisar as consequências que a adoção das medidas de segurança acarretaram para países que as incorporaram na legislação de governos totalitários, nas primeiras décadas do século XX.

De qualquer modo, os fundamentos teóricos da Defesa Social estavam na necessidade de se harmonizar a realidade natural egoísta do homem com sua necessidade essencial de viver em sociedade. Era preciso encontrar na sociedade e na lei a atuação das exigências naturais dos homens que a compõem, e não um contraste com sua aspiração natural e humana de liberdade e bem-estar.

A organização do Estado deveria responder às exigências naturais do indivíduo. Assim, o Estado não podia limitar a liberdade do indivíduo com a única finalidade de lograr objetivos estranhos às finalidades naturais do ser. O Estado deveria colocar-se a serviço dos homens.

Assim, o Estado adquire deveres, antes que direitos, frente aos seus componentes. De outro lado, o Estado há de ter uma esfera de poder: o de vencer os egoísmos individuais, para o bem dos demais indivíduos que hão de viver em sociedade. O poder do Estado, contudo, deve atuar em benefício de cada um.

Em razão da submissão do Estado aos limites que os direitos fundamentais do homem impõem, a atividade legislativa deve ser concebida não como expressão de luta entre o Estado e o indivíduo, mas como atividade dirigida ao seu bem-estar, inclusive no momento em que impõe sobre o indivíduo proibições ${ }^{76}$.

A função preventiva especial da pena, expressa na ideologia de tratamento e recuperação do delinquente, tão presente na ideologia da Defesa Social, reflete esse caráter

\footnotetext{
${ }^{75}$ ANCEL, Marc. A nova Defesa Social, p. 16.

${ }^{76}$ GRAMATICA, Filippo. Principios de Defensa Social, p. 51.
} 
humanista. Ao contrário de reagir ao crime causando sofrimento, desonra e sacrificando a personalidade do indivíduo, proclama-se o dever do Estado de ajudar seus súditos, de socializar e recuperar o indivíduo.

O movimento de Defesa Social, se não constitui um claro desdobramento do Positivismo Criminológico italiano, encontra nele suas ideias fundamentais e verdadeiras raízes. É a partir da revolta positivista, e unicamente em favor da corrente de pensamento criada por ela, que as noções de defesa social puderam aparecer, pela primeira vez, em sua verdadeira forma.

O movimento das ideias do final do século XIX reagiu contra o Direito Penal então construído como uma técnica jurídica na qual o raciocínio abstrato se mantinha em primeiro plano e segundo a qual o delito permanecia, antes de tudo, uma entidade jurídica.

Seus questionamentos se voltavam contra a noção da responsabilidade moral e as teorias tradicionais sobre a legitimidade e as funções da pena. O movimento pretendia substituir a lógica jurídica pura pelo método experimentalista das ciências naturais. Colocava-se em primeiro plano não mais o fato punível, mas o delinquente considerado em sua personalidade individual, em sua identidade biológica e, em realidade, como profundamente dependente do meio social em que vive ${ }^{77}$.

Algumas posições chaves do positivismo criminológico, segundo Marc Ancel, tornaram viável a elaboração das primeiras teorias de Defesa Social. Em primeiro lugar, está a rejeição do livre-arbítrio, embora não constitua a essência do movimento, da mesma forma que o determinismo biológico ou social de Lombroso e de Ferri.

O autor assevera a maneira como os positivistas consideram o problema da delinquência supõe que o novo Direito Penal, em oposição ao Direito Penal tradicional, não seria mais estabelecido em função do homem delinquente clássico. Como consequência direta, o próprio delito seria considerado não mais como uma abstração ou como uma entidade jurídica, mas como um fato natural e social, como ato humano que se

${ }^{77}$ ANCEL, Marc. Op. cit, p. 60. 
deve examinar não somente de forma objetiva, mas em sua realidade subjetiva e em relação à personalidade concreta do seu autor e essa personalidade do autor deve ser em si mesma cientificamente examinada ${ }^{78}$.

A justiça penal não teria mais como missão punir a culpa, mas sim a proteção da sociedade contra o crime, e é nessa direção que os positivistas falariam por primeiro em defesa social: a função punitiva torna-se uma pura e simples função de defesa social.

Essas novas legislação e justiça penais só poderiam desempenhar suas tarefas de proteção social se orientadas segundo os ensinamentos bem assimilados da Antropologia e da Sociologia criminal. Essa reforma do Direito Penal apoiava-se, portanto, desde o início, na Criminologia ${ }^{79}$.

Todas essas premissas constituíram a célula mater que permitiu o surgimento das primeiras teorias da Defesa Social. Nas palavras de Marc Ancel:

\footnotetext{
"Esse surgimento, nós o repetimos, é posterior à própria formulação da doutrina positivista, pois se o Positivismo contém em germe essa primeira teoria da defesa social, ele não a formula como tal. A defesa social não é uma doutrina do Positivismo, mas uma consequência indireta, e de certa forma em segundo grau, da doutrina positivista” ${ }^{80}$.
}

De fato, a utilização do termo “defesa social”, pelos positivistas, não lhe atribuía o caráter de uma teoria autônoma, mas significava a proteção do corpo social. A primeira teoria da Defesa Social, segundo aquele autor, surgiria com a União Internacional de Direito Penal, vertente positivista criminológica de caráter eclético e moderado, fundada por Von Liszt, Van Hamel e Adolphe Prins ${ }^{81}$.

\footnotetext{
${ }^{78}$ Idem, ibidem, p. 85.

${ }^{79}$ Idem, ibidem, p. 86-87.

${ }^{80}$ Idem, ibidem, p. 87.

81 Importa notar que, a despeito da preocupação do fundador da chamada Nova Defesa Social com a independência das ideias do movimento de defesa social elaborado no século XX, em pouco elas diferiam das principais premissas preconizadas pelos positivistas italianos. Com singelas diferenças, especialmente ligadas a posicionamentos doutrinários a respeito das finalidades da pena e o fundamento do direito de punir, o sistema que buscavam implementar as legislações penais na época, e que, efetivamente, acabou por invadilas, era praticamente o mesmo, conforme se verá mais adiante.
} 
Liszt foi quem primeiro colocou em primeiro plano as exigências e a própria noção de uma Política Criminal cientificamente orientada e que teria por objeto essencial adaptar a pena ou a sanção à personalidade do delinquente ${ }^{82}$. Mas coube a Adolphe Prins a formulação da primeira teoria da Defesa Social, registrada na obra La Défense Sociale et les transformations du droit penal, de $1910^{83}$

\footnotetext{
“O que, para Adolphe Prins, torna essa teoria necessária é a insuficiência da teoria clássica da responsabilidade moral. Doutrinariamente, a teoria da responsabilidade moral conduz a uma alternativa impossível entre o determinismo e o livre-arbítrio. Na prática, ela conduz a multiplicar as penas restritivas de liberdade de pequena duração e a dar lugar cada vez mais à noção de responsabilidade atenuada, o que deixa a Sociedade indefesa em relação aos criminosos mais perigosos. Assim, a lei e a justiça penais baseadas na responsabilidade moral não propiciam uma proteção eficaz da comunidade social” ${ }^{84}$.
}

Para Prinz, o objetivo de garantir, da melhor maneira possível, a proteção da vida, do patrimônio e da honra dos cidadãos não será verdadeiramente atingido senão através da substituição da noção de responsabilidade moral pelo critério da periculosidade do delinquente. Considerando a periculosidade como um estado permanente do indivíduo, a ação do Estado poderia significar um prolongamento da restrição da liberdade, desde que ela se mostrasse indispensável à segurança social. Para tanto, deveriam ser consideradas as duas categorias essenciais de indivíduos perigosos: os anormais ou débeis e os reincidentes ou criminosos habituais, o que iria requerer a criação de novos estabelecimentos, em particular para os anormais ${ }^{85}$.

Para Prinz, as medidas de segurança e as penas indeterminadas constituíram as formas de garantia da liberdade individual e da proteção bem refletida da sociedade, pois essa proteção, para ser eficaz, deve ser mantida tanto tempo quanto a própria

\footnotetext{
${ }^{82}$ ANCEL, Marc. A Nova Defesa Social, p. 91.

${ }^{83}$ Idem, ibidem, loc. cit..

${ }^{84}$ Idem, ibidem, p. 92.

${ }^{85}$ Idem, ibidem, p. 93-94.
} 
periculosidade, inclusive por meio de medidas preventivas de caráter administrativo, com o fim de impedir que essa periculosidade se manifeste ${ }^{86}$.

É clara, como se percebe, a semelhança entre as teses positivistas e a teoria da Defesa Social inaugurada por esse autor.

Coincidindo, ainda, com as ideias de Garofalo, os partidários dessa primeira teoria de Prinz também reivindicavam uma classificação de delinquentes, sem, contudo, tomar posições dogmáticas com respeito à etiologia do crime. Além disso, a nominação das medidas de segurança não estava claramente definida na sua obra, limitando-se a reclamar medidas diferentes das penas tradicionais e um pouco à maneira da preventive detention inglesa $^{87}$.

O período do Direito Penal autoritário marcou um recuo das ideias da Defesa Social, mas essa oposição, afirma Marc Ancel, acabou por ser proveitosa ao desígnio dessas ideias, já que a revolta da consciência humana, que se seguiu ao término da última guerra, inspirava-se, antes de tudo, numa reação contra esse desprezo pela dignidade humana, característica do totalitarismo. Assim, no período pós-guerra, o movimento da Defesa Social procurou superar os excessos desumanos que desonraram o século, esmerando-se para reencontrar uma tradição humanista e a repensar o problema criminal como problema social ${ }^{88}$.

A fase moderna da defesa social surge em 1945 e manifesta-se com destaque no plano internacional (do que é exemplo a constituição, em 1948, de uma Secção de Defesa

\footnotetext{
${ }^{86}$ Idem, ibidem, p. 95.

${ }^{87}$ Idem, ibidem, p. 97.

${ }^{88}$ Interessante notar, no trabalho de Marc Ancel, a recusa em admitir que a ideologia da Defesa Social serviu de instrumento ao autoritarismo de governos totalitários, como se assistiu com o nacional-socialismo, na Alemanha, e o governo fascista italiano: "Poder-se-ia crer, à primeira vista, que o movimento de defesa social se veria, senão reforçado, pelo menos facilitado pelo advento do direito penal autoritário. O Código Penal italiano de 1930, à época proclamado abertamente como código penal fascista e cujo autor se comprazia em afirmar que se tratava de um código político, introduziria e sistematizaria na Itália as medidas de segurança. O mesmo ocorreu com o regime nazista que, por uma lei de 1933, instaura na Alemanha um sistema de medidas de segurança, enquanto que outra, de 14 de julho do mesmo ano, instituía a esterilização, imposta a certos indivíduos, por razões eugênicas (....) Em todos esses casos, uma revolução oposta ao liberalismo antigo parecia, em extirpando as controvérsias doutrinárias, impor o recurso às medidas de segurança. No entanto, tudo não passa de uma mera aparência, pois os regimes autoritários enfatizaram sobretudo a pena retributiva e intimidante”. Op. cit., p. 109.
} 
Social junto ao secretariado geral das Nações Unidas que viria a absorver, em 1950, a Comissão Internacional Penal e Penitenciária). Tratava-se de uma política criminal de prevenção do crime e tratamento de delinquentes ${ }^{89}$.

A última fase, segundo a cronologia de Marc Ancel, caracterizou-se pela formação de duas grandes correntes divergentes do movimento. Entre o segundo e o terceiro Congresso Internacional de Defesa Social, realizado em 1954, em Anvers, foram realizadas duas sessões preparatórias nas quais Filippo Gramatica, então presidente da nova Sociedade Internacional de Defesa Social, e seus discípulos desenvolveram teorias ditas audaciosas que suscitaram reservas acentuadas entre numerosos participantes, como também entre alguns dirigentes da Sociedade Internacional de Defesa Social.

O resultado foi a elaboração do chamado programa mínimo ${ }^{90}$ da Sociedade Internacional de Defesa Social que, quando apresentado ao Congresso de Anvers, assumiu duas tendências: uma moderada e outra extremista. A primeira tornar-se-ia a posição adotada no próximo colóquio de Belaggio, realizado em 1963, e constituiria o elemento dominante da 5 a etapa do desenvolvimento da defesa social.

A segunda foi responsável pela inauguração de uma posição extremada liderada por Filippo Gramatica que, desde 1945 e já em outras obras, propunha o seu sistema de Direito Penal Subjetivo, ou Sistema de Defesa Social, cujo objetivo era substituir o Direito Penal em vigor $^{91}$.

${ }^{89}$ Idem, ibidem, p. 114-116.

90 O programa mínimo de Defesa Social tinha como primeiro objetivo assegurar o respeito aos valores humanos. Também o Direito Penal deveria assegurar tais direitos, acatando todas as prescrições de uma legalidade restrita. Os princípios de liberdade e legalidade, como resultado do desenvolvimento histórico da sociedade moderna deveriam ser considerados como invioláveis. Ele concluía, como anúncio de um sistema de direito, as seguintes diretrizes: “(...)- convém buscar e coordenar as diversas medidas tomadas pelo Direito Penal para chegar, o antes possível, a um sistema único de reação social contra o fato criminal; importa que este sistema esteja o suficientemente diferenciado para permitir ao tribunal o poder de eleger, em cada caso particular, a medida apropriada à situação daquele que seja objeto do ajuizamento; - o procedimento judicial e o tratamento penitenciário com respeito ao delinquente objeto dos mesmos deverão ser considerados como fases sucessivas inspiradas nas normas e no espírito da defesa social". GRAMATICA, Filippo. Princípios de Defensa Social, p. 35.

${ }^{91}$ Gramatica, antes da publicação do seu Princípios de Defesa Social, havia elaborado uma teoria de Direito Penal Subjetivo, cuja principal característica era a punibilidade vinculada à intencionalidade do sujeito do crime. A proposta era a subjetivação de todo o sistema penal. O fim específico da pena era atuar sobre a personalidade psíquica do sujeito e, apenas em segundo plano, promover a tutela de bens jurídicos. A culpabilidade consistia na consciência versante no ilícito jurídico. Onde não existisse tal intenção delitiva ou consciência antijurídica, não poderia haver delito, nem teria razão de ser a pena. Tanto maior era a pena 
Em Princípios de Defesa Social, Gramatica retoma as bases do seu Princípios do Direito Penal Subjetivo, reelaborando-as em muitos pontos, dando corpo, ao final, a um novo sistema, com a pretensão de substituir o então vigente Direito Penal.

Já sob a base teórica do movimento da Defesa Social, Gramatica propõe a extinção do conceito de delito, de pena e de responsabilidade, e a criação do critério de antissociabilidade do sujeito como fundamento da punibilidade. Daquelas premissas anteriores ao Princípios de Direito Penal Subjetivo, subsistiu a ideia central da valoração da personalidade do sujeito como critério para a responsabilização criminal.

Nesse ponto - e porque agora se mostrava mais condizente com os fundamentos do movimento da Defesa Social — o autor retoma a já conhecida luta contra a posição clássica a respeito da responsabilidade criminal pelo fato e a aplicação da pena na proporção do dano causado. A pena não poderia mais responder ao critério e à função do sistema clássico, qual seja, da proporcionalidade entre a pena e o dano. A individualização da pena pela valoração da personalidade do sujeito, segundo ele, era uma nova e generalizada aspiração da doutrina penal

\begin{abstract}
"Trasladado el centro de gravedad y el consiguiente criterio de valoración a la relación entre el medio de defensa social y el valor socio-bio-psicológico del autor, antisociabilidad, surge en el campo de la legislación una nueva aspiración humanística, una exigencia profunda de lógicas transformaciones prácticas. La defensa de la sociedad referida al individuo, como ser humano y social, no puede limitarse a ser un fin en sí misma, como lo es hoy la pena; ha de tender, mejor y más racionalmente, a la defensa de la sociedad; pero, además, a la mejora y a la recuperación del sujeto y, sobre todo, a la desaparición de las causas que han
\end{abstract}

quanto maior a intenção antijurídica demonstrada pelo autor. De outro lado, um fato objetivamente considerado como delito perderia seu caráter de antijurídico quando o agente, ainda havendo consumado os atos necessários para integrá-lo, tenha obrado, por exemplo, de boa-fé. Isso significa que a intenção, sob o aspecto de consciência e vontade do evento, ainda que concorrendo à construção técnica do ilícito, não o completa nem o caracteriza e, portanto, não gera responsabilidade criminal. O juiz, para declarar responsável o réu, segundo o sistema preconizado pelo autor, deveria averiguar e valorar a verdadeira intencionalidade ilícita, precisamente aquele acúmulo de circunstâncias que a indagação processual pode proporcionar. Ademais, a capacidade do juiz deveria referir-se não só à acumulação e avaliação das provas contra o sujeito do delito, senão estender-se a cognições próprias de Psicologia, para assegurar-se da real intenção antijurídica do réu. Sobre o sistema de Direito Penal Subjetivo, ver GRAMATICA, Filippo. Princípios de Derecho Penal Subjetivo. Madrid: Instituto Editorial Reus, 1941. 
convertido en antisocial al sujeto. La pena, en su concepción tradicional, no responde, desde luego, a esta función”,

Para Gramatica, com a abolição da responsabilidade moral e sua substituição pelo critério da antissociabilidade subjetiva, surge a necessidade da substituição da pena, como simples meio de atemorização e castigo, por novas medidas de defesa social preventivas, curativas e educativas. A Defesa Social, afirma o autor, encontrou sua mais característica lição na abolição da pena: "Não mais uma pena para cada delito, senão uma medida adequada para cada pessoa" ${ }^{93}$.

Apesar das semelhanças com o positivismo criminológico, Gramatica coloca sua tese em posição crítica com relação às ideias positivistas. Afirma que, ainda que instaurando uma nova nomenclatura dos substitutos penais, eles reencarnaram neles os velhos sistemas de reclusão. Além disso, ao lado do delinquente, afirmou-se a noção de delito ou contravenção, agravando, inclusive, a noção de responsabilidade penal com a ideia da responsabilidade penal ou legal eminentemente objetiva.

Também o conceito de delinquente, para Gramatica, difere do conceito concebido pelos positivistas. Para ele, se delinquente é o autor do delito (que não é outra coisa que a violação da norma penal), então é a norma penal que cria o delinquente, o que faz cair por terra a teoria do delinquente natural de Garofalo ou a ideia de Ferri de que todo autor de um crime é um delinquente. O sujeito de direito, afirma, é somente o homem, e não uma categoria particular denominada delinquente ou criminoso ${ }^{94}$.

Outra gritante diferença que guarda com relação aos preceitos positivistas é a ideia de que a ciência que estuda o autor do crime não deve vincular-se a uma categoria, senão deve olhar o estudo do sujeito em sua integralidade e unicidade. A Antropologia deveria ser tomada em sentido amplo, com seus aspectos biológicos, sociológicos e sociais. O seu conceito de "antissociabilidade” não é nada mais que uma mera definição, e não uma condição psíquica ou biológica.

\footnotetext{
92 GRAMATICA, Filippo. Principios de Defensa Social, p. 28-29.

93 Trad. livre. Idem, ibidem, p. 29.

${ }^{94}$ Idem, ibidem, p. 86.
} 
Além disso, ao Direito de Defesa Social somente interessam os homens sãos, conscientes. À Medicina, interessam os homens enfermos ou inconscientes. Assim, quando a violação da lei seja resultado de alterações patológicas da personalidade, o violador será incluído na categoria dos enfermos, e as normas a ele aplicáveis serão as da Medicina:

\footnotetext{
"No existen, por lo tanto, dos categorías o tipos de hombres: delincuentes e no delincuentes, sino el hombre que, algunas veces, al encontrarse frente a la prohibición de una determinada ley la viola, asumiendo, entonces, legalmente, la característica de antisocial” ${ }^{95}$.
}

Sua premissa tem relação direta com os fundamentos teóricos de Gramatica de que o homem é essencialmente egoísta e rebelde, potencialmente delinquente ou antissocial. A sociedade o corrige e socializa e, portanto, atua em seu favor, ao tempo que promove a defesa de todo o corpo social.

A posição inovadora de Gramatica coloca sua tese em confronto com as ideias positivistas, apelando a um subjetivismo ínsito no conceito de antissociabilidade ${ }^{96}$ regido por princípios estritamente jurídicos, em função da melhora do sujeito, recomendada às oportunas medidas de defesa social.

O sistema que propõe é um substituto do Direito Penal, onde estão ausentes a pena e o direito de punir do Estado.

Tal sistema, cujo objetivo não é mais a tutela de bens, mas o tratamento do indivíduo, mostra-se incompatível com o sistema punitivo. A valorização do sujeito leva a considerar, a sua vez, a personalidade em seus elementos subjetivos como condição para

${ }^{95}$ Idem, ibidem, p. 91.

${ }^{96}$ A antissociabilidade que Gramatica descreve seria uma representação unitária do elemento subjetivo, já que substitui a instituição da responsabilidade e absorve toda a carga subjetiva que lhe pode oferecer a perigosidade. Ela, segundo os positivistas, seria o cálculo naturalista de probabilidade - a despeito das tentativas de alguns autores de subjetivizar a periculosidade. O sistema de Gramatica não é nem materialista (perigosidade) nem abstratamente moral (culpabilidade), mas sim psicológico, voltado a compreender ambas as hipóteses ou categorias em um sistema unitário. A ideia, no entanto, não fica totalmente clara, sobretudo quando o autor afirma que a antissociabilidade deve ser entendida como categoria jurídica, mera definição abstrata. 
que a pena possa ser aplicada individualmente àquele que infringe o preceito da lei. E, por tal razão, propõe a substituição do antigo, para criação de um novo sistema jurídico-penal.

"Así como la sanción, que representa la medida de defensa social, tiene una función racionalmente 'subjetiva', el sistema de defensa social, tomado en conjunto, viene a encontrar en la finalidad de la mejora del individuo su verdadera razón de ser y la característica diferenciadora respecto de otras ramas del Derecho" ${ }^{97}$.

Em termos práticos, o sistema de Gramatica pugnava pela substituição da noção de responsabilidade penal em proporção ao dano causado, pela instauração da antissociabilidade como critério de valoração subjetiva e psicológica do autor da ação contrária à lei ${ }^{98}$. Isso levaria, por conseguinte, à abolição do delito e da responsabilidade penal e à criação do índice de antissociabilidade, que deveria ser valorada sempre subjetivamente ${ }^{99}$ :

\footnotetext{
"Subjetivar quiere decir, ante todo, relacionar el criterio de valoración jurídica con la personalidad del sujeto juzgable, con sus valores, con la conciencia con la cual el autor ha ejecutado la acción, y nunca, si no es como un elemento más para la valoración del sujeto, con las consecuencias del hecho; es decir, con el contenido objetivo del delito" ${ }^{100}$.
}

O fato delitivo é mero sintoma da antissociabilidade do autor. Portanto, não existe responsabilidade no sujeito pelo fato realizado. "Só existe uma psicologia individual antissocial que deve ser corrigida em atenção à necessária participação do indivíduo na vida social $^{101}$.

\footnotetext{
${ }^{97}$ Idem, ibidem, p. 65.

98 Para Gramatica, o caminho mais racional para a valoração do aspecto ético da conduta delitiva é a valoração da personalidade do autor. A análise da personalidade de quem não possui o sentido moral e ético dos próprios atos em relação com a sociedade, para ele, será qualificada de antissocial; um estado subjetivo do individuo contrário ao querido pela lei. A valoração da antissociabilidade em tais termos, segundo seu entendimento, teria um resultado certamente mais exato do ponto de vista natural do que através do conceito jurídico de responsabilidade pelo fato. Op. cit., p. 79.

${ }^{99}$ Idem, ibidem, p. 67.

${ }^{100}$ Idem, ibidem, p. 69.

${ }^{101}$ Idem, ibidem, p. 74.
} 
Por essas razões, um sistema de normas que rege essa peculiar esfera do Direito não poderá denominar-se Direito Penal, senão Direito de Defesa Social contra a antissociabilidade.

\subsubsection{A Nova Defesa Social e o pensamento de Marc Ancel}

Rompendo com a posição radical de Gramatica, Marc Ancel propôs a formulação de uma doutrina nova, mais moderada. Com o termo Nova Defesa Social, o autor pretende denominar

\footnotetext{
“Um sistema que, sobretudo, à luz dos ensinamentos da ciência moderna e da evolução da legislação penal positiva, busque se inserir no direito penal existente com o objetivo de transformá-lo, sem de forma alguma rejeitá-lo, e mesmo conservando seu valor essencial de expressão do Estado de direito” ${ }^{102}$.
}

As posições fundamentais da nova doutrina da Defesa Social consistem, em primeiro lugar, numa reação contra os excessos do "juridicismo”, o que reflete a importância e influência das ciências humanas no estudo do fenômeno criminal.

Os princípios do Direito Criminal, suas noções de base e teorias não se justificam senão na medida em que concorrem para essa finalidade social a que se propõe a Política Criminal. A Defesa Social busca ultrapassar a fórmula abstrata e apreender a realidade social, único fator que deve servir de base à nova política criminal.

Em muitos pontos as modernas teorias da defesa social se opunham às teorias do positivismo. De qualquer forma, independentemente de suas distintas premissas básicas, ambas culminavam em idênticos propósitos, cuja principal característica era a análise da personalidade do agente na individualização da pena voltadas para o tratamento e a recuperação do delinquente.

102 ANCEL, Marc. A Nova Defesa Social, p. 125. 
A Nova Defesa Social rejeita de forma resoluta o determinismo positivista. Coloca em primeiro plano a classificação dos delinquentes, mas não confia nas divisões tradicionais que tendem a classificar os autores dos atos criminais em distintas categorias. Para a Nova Defesa Social, o ato criminal é, antes de tudo, a expressão da personalidade individual, daí a preocupação em pesquisar ou explicar por que esse homem em particular praticou determinada ação.

Reexaminando a noção de responsabilidade do ponto de vista do homem em si, naturalmente se deve buscar nesse indivíduo o sentimento de obrigação moral. Assim, segundo Marc Ancel, é reintroduzida no Direito Penal a noção de culpa, embora afastada tanto do sentido de responsabilidade legal dos positivistas como da responsabilidade moral abstrata dos representantes do neoclassicismo tradicional ${ }^{103}$.

A Nova Defesa Social busca estabelecer um equilíbrio entre o indivíduo e a sociedade, graças a uma política criminal baseada na ideia de que a própria sociedade tem deveres para com o cidadão. Por essa razão, as medidas de segurança devem ser submetidas a um regime de estrita legalidade, por meio de intervenção judiciária ${ }^{104}$.

O movimento, em teoria, possui um caráter especificamente não repressivo. A atitude que pretende adotar em relação ao delinquente exige, em primeiro lugar, que se leve em consideração a sua própria personalidade, por meio de estudo sistemático levado a efeito segundo métodos e perspectivas científicos:

\footnotetext{
“A consideração da personalidade do delinquente constitui o primeiro traço dessa nova atitude que se lhe dispensa - uma característica da defesa social moderna. Neste ponto, sem dúvida, a doutrina se aproxima do Positivismo; mas ao mesmo tempo, ela se inter-relaciona com esse movimento mais amplo que consistiu na
}

\footnotetext{
${ }^{103}$ Idem, ibidem, p. 241-242.

${ }^{104}$ Marc Ancel via como superado o modelo de acúmulo de pena e medida de segurança. Defendia que o juiz deveria optar entre a pena ou a medida de segurança (sistema alternativo). Para ele, "a condição primordial para um desenvolvimento harmonioso das sanções penais, dentro do espírito e perspectiva dessa nova política criminal e graças ao desprezo da qualificação das 'penas' ou 'medidas', consiste em sua utilização livre, socialmente orientada e cientificamente individualizada (...) é nesse sentido que na nova doutrina da defesa social existe não unificação, mas integração da pena e medida de segurança. Isto, num sistema unitário de sanções penais baseado em critérios a um tempo físicos, sociais e morais, e ordenado por uma política criminal em que o direito penal desempenha tão-somente seu papel normal, mas essencial, de técnica destinada a servir de garantia necessária à liberdade individual” Op. cit., p.303-304.
} 
'irrupção da personalidade do criminoso no campo do direito penal', como bem lembrou Paul Cornil na abertura do Ciclo de estudos das Nações Unidas de dezembro de 1951, consagrado, precisamente, ao estudo científico do delinquente. Na consideração dessa personalidade, pouco a pouco livrou-se do biologismo lombrosiano e do fatalismo sociológico de Ferri não somente porque se objetiva doravante compreender o homem como membro da Sociedade e em seu próprio meio, com todas as influências e todas as deformações de que é objeto, mas porque, indo além do ser biopsíquico e mesmo do ser social, a nova doutrina pretende reencontrar o ser humano, considerado não como objeto de estudo científico, mas como sujeito de direito” ${ }^{\text {105. }}$.

De fato, a noção de personalidade do delinquente tende, então, a ser a principal dentre as preocupações dos criminalistas modernos e a ênfase dada a essa personalidade produz, segundo Marc Ancel, um resultado totalmente diverso do que lhe atribuíam os Positivistas. A consideração da personalidade do delinquente, no plano da sua nova política criminal, se traduz pela adoção das seguintes posições:

\footnotetext{
"O delinquente deve ser integrado ao processo penal, que até agora era unicamente o julgamento de um ato (...) o juiz continua a julgar o ato qualificado de infração não somente segundo o critério objetivo da lei, mas também em função dos elementos subjetivos da personalidade de seu autor” ${ }^{106}$.
}

O conhecimento dessa personalidade exige, portanto, que o juiz conheça técnica e profundamente o delinquente:

\footnotetext{
"Mas esse conhecimento difere claramente da apreciação judiciária a que tendia no século passado o primeiro movimento da individualização da pena (...) Tratase de sua constituição biológica, de suas reações psicológicas, de sua história pessoal e de sua situação social, e é assim que surge no processo penal moderno a necessidade do exame científico do delinquente" ${ }^{307}$.
}

\footnotetext{
${ }^{105}$ Idem, ibidem, p.280-282.

${ }^{106}$ Idem, ibidem, p. 282.

${ }^{107}$ Idem, ibidem, loc. cit.
} 
A evolução da legislação penal moderna consagrou a análise da personalidade como obrigação do juiz, como parte do processo de individualização da pena. Conforme ressalta o autor, a necessidade de integrar o estudo da personalidade no processo penal ganhou codificação no Código Penal francês de 1958 (o denominado dossiê de personalidade) ${ }^{108}$. A questão do exame de personalidade também foi objeto de discussão no Ciclo de Estudos organizado pelas Nações Unidas em Bruxelas, em 1951. Alguns criminalistas da Bélgica e da França, anota o autor, chegaram a reclamar a divisão do processo em das fases ${ }^{109}$.

\footnotetext{
“A admissão progressiva dessa exigência legal deriva de fato de uma conscientização cada vez mais completa das condições necessárias à sentença individualizada: o que não passava de uma faculdade ou mesmo de uma tolerância torna-se uma obrigação (...) a lei penal entende que doravante a pena não deve ser estabelecida senão após levar em consideração, explícita e justificadamente, um certo número de elementos tidos como indispensáveis ao exercício racional do grande poder de apreciação que os novos códigos atribuem ao juiz penal” ${ }^{110}$.
}

Para Marc Ancel, trata-se de uma política criminal deliberadamente adotada com vistas a assegurar uma mais eficiente reação social contra o crime e que "bastará um desenvolvimento complementar para conduzir à organização do exame médicopsicológico e social e ao dossiê de personalidade: é desnecessário dizer que nos situamos aqui dentro da própria corrente de ideias da nova defesa social” ${ }^{111}$.

\subsection{A influência do positivismo criminológico e da defesa social nas legislações e no pensamento jurídico-penal}

\footnotetext{
${ }^{108}$ Conforme afirma o autor, "Na França, em seguida a uma notável decisão do Tribunal de Sena de 6 de março de 1956, os tribunais, em certos casos, especialmente em se tratando de acusado passível de pena de relegação ou, por outra, suscetível de se beneficiar da suspensão condicional da pena, admitem ser possível determinar que peritos examinem a personalidade delinquente e opinem sobre sua eventual periculosidade e perspectivas de reinserção social, antes da decisão judiciária. Em Strasbourg, em 1957, a V Jornada Francesa de Defesa Social estudava por sua vez o dossiê de personalidade, e a Fundação Internacional Penal e Penitenciária consagrava em 1959 um importante Ciclo de estudos à observação dos delinquentes". Op. cit., p.284-285.

${ }^{109}$ Idem, ibidem, p. 289.

${ }^{110}$ Idem, ibidem, p.161.

${ }^{111}$ Idem, ibidem, p.163.
} 
O triunfo da Criminologia Positivista sobre os enunciados da Escola Clássica permeou a dogmática jurídico-penal e influenciou a elaboração das leis penais do início do século XX de forma decisiva.

É inegável que a profusão das ideias da Escola Positivista, sobretudo nas primeiras décadas do século XX, levou a resultados visíveis no campo legislativo e doutrinário ${ }^{112}$.

Também conquistaram espaço as medidas assecurativas contra os delinquentes moralmente irresponsáveis, inclusive os habituais, e a pena por tempo indeterminado.

Dentre as ideias da Escola Positivista, Ferri propôs - e obteve considerável sucesso na repercussão dessas ideias - a independência da justiça penal com relação à ideia do livre-arbítrio; a defesa social como razão da justiça punitiva; as três ordens de fatores do delito (fatores individuais, físicos e sociais); as cinco categorias de delinquentes (nato, louco, habitual, ocasional e passional); os substitutivos penais como atuação da defesa preventiva indireta; o critério dos motivos determinantes na interpretação das leis vigentes; as colônias agrícolas substitutivas do isolamento celular diurno; a segregação por tempo indeterminado substitutiva da dosimetria penal com termo fixo; a necessidade de manicômios criminais; o ressarcimento do dano como sanção de direito público e, sobretudo, a necessidade do método (para o científico, para o legislador e para o juiz) de considerar-se o delito no delinquente ${ }^{113}$.

Todas essas premissas, com exceção do critério da responsabilidade legal, lograram ingressar no pensamento jurídico-penal e nas legislações do século $\mathrm{XX}^{114}$.

E, ainda que as teorias antropológico-causais da Escola Positivista e da Escola da Defesa Social não tenham penetrado os Códigos Penais exatamente na forma como

\footnotetext{
${ }^{112}$ Nesse sentido, Víctor Gómez Martín cita como exemplos de incorporações legislativas influenciadas por considerações criminológicas aquelas referidas à perigosidade do delinquente, como a circunstância agravante da reincidência, alguns critérios legais de determinação da pena, as regras especiais para cumprimento da pena privativa de liberdade, as medidas de segurança e, no que respeita ao Direito Penal alemão, os princípios de determinação da pena previstos no §46 [2] StGb . Op. cit., p. 81.

${ }^{113}$ ANCEL, Marc. Op. cit., p. 53-54.

${ }^{114}$ Importa observar que o Código Penal Russo de 1927 admitiu o critério da responsabilidade legal e o projeto para o Código Penal de Cuba, de 1926 propunha a norma básica da responsabilidade legal para todos os delinquentes. Idem, ibidem, p. 59.
} 
concebidas, o fato é que "muito ficou e muito perdura ainda da sua herança: não tanto no que toca aos parâmetros metodológicos, quanto no que respeita às linhas de força da sua ideologia político-criminal” 115.

Como bem adverte o professor português, a chamada ideologia do tratamento está longe de poder ser considerada superada e seus perigos estão longe de se poderem considerar neutralizados $^{116}$. A ideologia de tratamento e suas concepções de política criminal constituem, para ele, o essencial do positivismo:

\footnotetext{
“Estas, na verdade, como que inverteram o sentido da escola clássica: em vez do recuo do poder sancionatório da sociedade, em nome da expansão dos direitos dos indivíduos, preconizavam a ampliação das exigências e direitos da sociedade sobre o delinquente; à ideia de responsabilidade pessoal faziam suceder a da responsabilidade social; não cuidavam de punir segundo a gravidade da culpa, mas de reforçar a defesa da sociedade; não reconheciam, por isso, à reação criminal outra medida que não a da necessidade em função da ameaça temebilitá (Garófalo) ou da periculosità (Ferri) - do delinquente”117.
}

Instrumento decisivo para a consolidação e difusão da Criminologia como ciência, em nível internacional, foram a criação e a institucionalização de organizações internacionais que buscavam desenvolver normas universais para o enfrentamento dos problemas delitivos. Inúmeros congressos internacionais de Criminologia e Antropologia Criminal passaram a ser organizados, contando com a presença de penalistas dos mais diversos países.

Rosa del Olmo relata que o I Congresso Internacional de Antropologia Criminal ocorreu em 1885, em Roma, contando com a presença de Garofalo, Ferri e Lombroso. A finalidade dos debates, segundo a autora, foi a discussão mais profunda a respeito das ideias da Escola Positivista italiana e particularmente a teoria de Lombroso sobre o criminoso nato, publicada pela primeira vez em $1876^{118}$.

\footnotetext{
${ }^{115}$ DIAS, Jorge de Figueiredo. Op. cit., p. 18.

${ }^{116}$ Idem, ibidem, loc. cit..

${ }^{117}$ Idem, ibidem, p. 19.

${ }^{118}$ DEL OLMO, Rosa. A América Latina e sua Criminologia, p. 88.
} 
O II Congresso realizou-se em Paris, em 1889, já contando com os oposicionistas a Garofalo, dentre eles Gabriel Tarde, Lacassagne, Manouvier e Topinard, membros da Escola Francesa de Sociologia e defensores do predomínio dos fatores sociais como causas da delinquência.

Lombroso, Ferri e Garofalo reaparecem apenas no IV Congresso Internacional, realizado em Genebra, em 1896. Especial destaque merece o fato de, nesse congresso, Lombroso apresentar algumas reformulações à sua ideia original a respeito do criminoso nato. Ferri, na mesma ocasião, refere-se ao delinquente como um indivíduo dotado de uma personalidade completa, ao mesmo tempo biológica, psicológica e social ${ }^{119}$.

Representantes da América Latina apenas vão comparecer a partir no V Congresso de Antropologia Criminal, ocorrido em Amsterdã, em 1901, com a presença do argentino Norberto Piñero, um dos mais importantes representantes do Positivismo de seu país. Ao VI Congresso de Antropologia Criminal, reunido em Turin, em 1906, foram enviados vários representantes de países latino-americanos, contribuindo para a difusão e internacionalização daqueles trabalhos na América Latina ${ }^{120}$.

As principais conclusões gerais resultantes dos sete congressos de Antropologia Criminal realizados entre 1885 e 1911 versam sobre as características físicas dos delinquentes; a relação entre loucura e delinquência e, particularmente, a relação entre a degeneração física e moral com o crime. Ainda como resultado daqueles debates, passa a ganhar corpo a ideia de possibilidade de tratamento do delinquente, com a ajuda da Antropologia Criminal e da Psiquiatria, abrindo campo para a ideologia de tratamento e da finalidade de prevenção especial da pena ${ }^{121}$.

A União Internacional de Direito Penal também foi fonte de profusão e longos debates daqueles princípios. Embora seus fundadores fossem defensores de tendências ecléticas da Escola Positivista, a Associação defendia ideias fundamentalmente ligadas ao

\footnotetext{
${ }^{119}$ Idem, ibidem, p.91-92.

${ }^{120}$ Idem, ibidem, p. 93-94.

${ }^{121}$ Idem, ibidem, loc. cit..
} 
positivismo criminológico, em especial, o conceito de perigosidade, a aplicação das medidas de segurança e a formação especializada dos juízes penais ${ }^{122}$.

Dentre seus membros representantes, encontravam-se penalistas latino-americanos, como Luis Maria Drago, José N. Matienzo e Norberto Piñero, da Argentina. Do Brasil, o professor de Direito Penal da Faculdade de Direito do Recife, João Vieira Araújo. Do Chile, Aníbal Echeverría y Reyes. Também eram representantes latinos na União Octávio Beeche, da Costa Rica, Agustín Gómez Carrillo, Manuel Echeverría e Baltazar Estupidam, da Guatemala e, da Venezuela, Francisco Ochoa ${ }^{123}$.

A União Internacional de Direito Penal, extinta em 1914, publicou, ao todo, 14 boletins, nos quais se esforçou para criar normas universais de ação contra o delito. Dentre as principais definições estabelecidas, Rosa del Olmo aponta os seguintes princípios:

\footnotetext{
1- O delito não é somente uma entidade abstrata de ordem jurídica, mas também um fenômeno social de caráter patológico influenciado por fatores individuais, congênitos ou adquiridos. A luta deve ser antecipada mediante a investigação científica de tais causas.

2- O direito penal deve estudar os delinquentes em duas categorias: a) os que sucumbem ante poderosas influências exteriores, como a miséria e o alcoolismo; b) os que mantêm hábitos derivados de seu gênero de vida. Os primeiros são os ocasionais; os segundos, os habituais ou de natureza.

3- A pena não é suficiente contra o delito, mas indispensáveis medidas privativas da liberdade devem depender não somente do delito, mas do resultado penitenciário e, no que concerne às de curta duração ou de natureza benigna, podem ser substituídas por medidas equivalentes. Em todo o caso, os incorrigíveis devem ficar o maior tempo possível em situação de não provocar dano, mas é necessário que o regime de prisões responda aos ditames de uma política criminal sã ${ }^{124}$.
}

A influência dessas ideias permeou a produção legislativa de inúmeros países, a partir de fins do século XIX. Esse fato foi assim reconhecido por Anibal Bruno:

\footnotetext{
${ }^{122}$ Cf. BRUNO, Anibal. Direito Penal. Parte Geral. Tomo I, p.120.

${ }^{123}$ Cf. DEL OMO, Rosa. A América latina e sua Criminologia, p.98.

${ }^{124}$ Idem, ibidem, p. 19.
} 
“(...) passaram a fazer penetrar as legislações a consideração da personalidade do criminoso, colocada no centro do sistema, com as consequências que daí podiam derivar para os vários institutos penais. Ao lado da concepção objetiva, à maneira clássica, as novas legislações acolheriam a concepção sintomática do crime, isto é, do crime como sintoma de uma maneira de ser do sujeito, perigosa por si mesma para a convivência social, e contra esse estado mobilizariam as medidas convenientes para dirimir essa perigosidade ou obstar que ela cause dano; em suma, ao lado da culpabilidade, com a consequência da pena retributiva, erigiram o critério da perigosidade criminal, critério de fundo naturalista indisfarçável, como o corolário das medidas de segurança. E esta segunda concepção, que aparece em princípio como acessória, tende a infiltrar-se por todo o resto do sistema, enfraquecendo os pontos tradicionais do Direito Penal, fazendo o acento deslocar-se cada vez mais da repressão para a prevenção, da prevenção geral para a prevenção especial. Na admissão desse novo critério, isto é, nesse dualismo - culpabilidade e perigosidade criminal, e pena e medida de segurança - característico da concorrência dos dois rumos de ideias opostos, classicismo e positivismo, é que está o sinal distintivo das novas legislações”125.

Destarte, o giro subjetivista que marca as novas legislações penais influenciadas pelo positivismo criminológico e pelo movimento de Defesa Social traz como nota marcante a adoção da análise da personalidade do agente, colocada, agora, no centro do sistema penal. De outro lado, o juízo de periculosidade passa a justificar a adoção de medidas distintas da pena e, em alguns casos, orienta a aplicação da própria pena, o que acarreta numa profunda modificação da noção de responsabilidade criminal.

Anibal Bruno afirmava que esse novo modelo de legislações era o “mínimo das aspirações do positivismo, programa a cuja propagação muito serviu a União Internacional de Direito Penal” ${ }^{126}$. Ainda segundo este autor,

\footnotetext{
“Os projetos que alguns penalistas sugerem para um Direito Penal do futuro todos assentam nas ideias centrais do positivismo: na perigosidade criminal, como fundamento da ação do Estado sobre o criminoso, e na medida de defesa social, através da recuperação do delinquente, transformadas as penitenciárias em reformatórios e institutos de preservação e de cura. Assim, ela continua a influir nas legislações e na doutrina, por si ou através de escolas ecléticas, às
}

${ }^{125}$ Direito Penal. Parte Geral. Tomo I, p. 148.
${ }^{126}$ Idem, ibidem, p. 149. 
quais tem comunicado as suas ideias fundamentais, como uma das metades do dualismo sob o qual elas se desenvolvem. Reconhece hoje que a sua função é construir o Direito vigente, pela dogmática, e sugerir reformas oportunas, pela crítica, através da Política Criminal” ${ }^{127}$.

As chamadas medidas de defesa social também foram penetrando as legislações de toda parte do mundo. Marc Ancel aponta que a primeira verdadeira medida de segurança a surgir em legislação, no final do século XIX, foi a relegação francesa, de 1885, imitada em seguida pela lei portuguesa de 1892. Em 1891, a Bélgica retomava antiga noção de que dispunha o Governo para organizar uma proteção mais eficaz contra os vadios, por meio de medidas de segurança. O projeto Stoss, de 1893, trouxe a primeira expressão legislativa completa de um sistema de medidas de segurança e, após sua promulgação com o Código Penal suíço de 1937, inaugurou uma série de códigos penais do século $\mathrm{XX}^{128}$.

As medidas de segurança invadiram as legislações mesmo onde não eram reconhecidas oficialmente sob essa denominação técnica. Na Espanha, no Código de 1928, na Iugoslávia, no Código de 1929. Também nos Códigos penais italiano e dinamarquês, de 1930, o Código polonês de 1932 e o Código cubano de 1936. Na América latina, surgem no Código colombiano de 1936 e no Código Penal brasileiro de 1940.

Mesmo onde a lei não lhes consagra um capítulo à parte, um lugar lhes é reservado, como é o caso do Código penal argentino, de $1922^{129}$. O Código Penal uruguaio, de 1933, elaborado por Irueta Goyena, cedeu à ideia da perigosidade criminal inclusive no domínio da pena.

Além dos Códigos Penais, por toda parte surgem leis especiais, adotando medidas de segurança, como a Suécia, em 1928, Tchecoslováquia, em 1929, Bélgica, em 1930, e a Finlândia, em $1932^{130}$.

\footnotetext{
${ }^{127}$ Idem, ibidem, p. 120.

${ }^{128}$ Cf. MARC, Ancel. A Nova Defesa Social, p. 102.

${ }^{129}$ Idem, ibidem, p. 105.

${ }^{130}$ Idem, ibidem, passim.
} 


\section{SUBJETIVAÇÃO DA LEGISLAÇÃO PENAL BRASILEIRA}

\subsection{A influência do positivismo criminológico e das ideias de defesa social na legislação e no pensamento jurídico-penal brasileiros}

No Brasil, os postulados positivistas, ao contrário do que chegaram a manifestar os próprios penalistas da época ${ }^{131}$, também ingressaram no ordenamento jurídico-penal. A análise da personalidade do agente alcançou, em determinado ponto da evolução da nossa legislação, o posto de elemento principal para fins de aplicação da lei penal. A periculosidade chegou a ter previsão também como medida da pena, e não apenas como pressuposto de aplicação das medidas de segurança.

Tão forte a influência daqueles postulados que, até o momento atual, esses conceitos permanecem previstos em nosso Código Penal, a despeito de terem perdido o vigor entre os doutrinadores, com o advento do finalismo.

Embora sempre marcada por um viés eclético e declaradamente influenciada pela escola técnico-jurídica (Terza Escuola), a produção legislativa brasileira consagrou os postulados da Escola Positivista italiana até a década de 70, com a edição da Lei $n^{0}$ $6.416 / 77^{132}$.

A doutrina jurídico-penal, de outro lado, adotou quase que cegamente a subjetividade inaugurada pela adoção daqueles conceitos pela legislação penal, levando inúmeros penalistas de escol defender a realização de exame pericial antes da sentença ou mesmo a especialização dos juízes criminais para possibilitar a análise da personalidade do

\footnotetext{
${ }^{131}$ Nelson Hungria negava veementemente a adoção das ideias da Escola Positivista italiana por nossa legislação e declarava-se, particularmente, opositor delas. Contraditoriamente, defendeu amplamente a adoção das medidas de segurança baseada na periculosidade, no Código Penal de 1940, do qual participou diretamente como membro da Comissão revisora, além de ter inserido em seu anteprojeto de Código Penal a pena indeterminada e a classificação de criminosos, com inspiração nos moldes da classificação de Enrico Ferri.

${ }^{132}$ A despeito das profundas alterações que trazia a Lei 6416/77, ela não eliminou o sistema do duplo binário e, ainda pior, trouxe como critério de aplicação da pena a periculosidade. A periculosidade, a exemplo do Projeto Nelson Hungria, era o centro do sistema de penas. Na contramão do pilar do Direito Penal do fato, a Lei $n^{0}$ 6416/77 preconizava a realização de estudos de prognose criminal sobre pessoas delinquentes para aferição de sua periculosidade. Mesmo tratando-se de um critério fluido e arbitrário, a periculosidade passou a ser critério de aplicação da pena.
} 
agente, antes da fixação da pena. São relativamente recentes as produções da doutrina penal nessa vertente, o que demonstra a atualidade dessa influência.

Declaração de periculosidade, medidas de segurança para imputáveis e pena indeterminada também foram incorporadas em textos legislativos no nosso ordenamento jurídico-penal.

Entre o final do século XIX até meados da segunda metade do século XX, médicos e juristas brasileiros buscaram consolidar a Criminologia como uma área de conhecimento pretensamente científico ${ }^{133}$. A influência das obras europeias tomou conta da literatura penal brasileira ${ }^{134}$, fato que levou também à reformulação do aparelhamento Judiciário do país ${ }^{135}$.

Nas universidades, as ideias da Antropologia Criminal começam a penetrar no país a partir do final do século XIX, acompanhando a onda cientificista propagada pela assim chamada geração de 1870, sobretudo a partir da Escola de Direito do Recife. João Vieira Araújo é considerado o "primeiro autor a se mostrar informado a respeito das novas teorias criminais, ao comentar as ideias de Lombroso em suas aulas na Faculdade do Recife e também em tetos sobre a legislação criminal do Império” ${ }^{136}$.

Outros juristas, durante a Primeira República, passaram a divulgar as novas abordagens científicas acerca do crime e do criminoso, segundo menciona Marcos Cesar Alvarez: Clovis Bevilaqua, José Higino, Paulo Egídio, Raimundo Pontes de Miranda, Viveiros de Castro, Aurelino Leal, Cândido Mota, Moniz Sodré de Aragão, Evaristo de Moraes, José Tavares Bastos, Esmeraldino Bandeira, Lemos Brito, entre outros, publicam artigos e livros em que são discutidos os principais conceitos e autores da Criminologia e da Escola Penal Positiva ${ }^{137}$.

\footnotetext{
133 ALVAREZ, Marcos Cesar. Apontamentos para uma História da Criminologia no Brasil, p. 137.

134 Dentre os autores brasileiros mais influenciados pelo positivismo, Anibal Bruno elenca João Vieira, Viveiros de Castro, Moniz Sodré, Candido Mota, Filinto Bastos, Evaristo de Moraes e José Higino.

${ }^{135}$ RAUTER, Cristina. Criminologia e Subjetividade no Brasil, p. 24.

${ }^{136}$ Cf. ALVAREZ, Marcos Cesar. Apontamentos para uma História da Criminologia no Brasil, p. 138.

${ }^{137}$ Idem, ibidem, loc. cit..
} 
Anibal Bruno absorve e desenvolve a fundo a teoria do estado perigoso, levando-a às últimas consequências, ao apresentar sua dissertação $A$ perigosidade criminal à Faculdade de Direito do Recife, em $1937^{138}$.

Cândido Mota, formado pela Faculdade de Direito do Largo São Francisco, buscou implementar tais conhecimentos a partir de sua carreira jurídica e política. Integrou a Sociedade de Antropologia Criminal, Psiquiatria e Medicina Legal, criada em 26 de outubro de 1895, ao lado de criminalistas como Brasilio Augusto Machado de Oliveira, Reynaldo Porchat, Antonio Amâncio Pereira de Carvalho e José Alcântara Machado, todos catedráticos da Faculdade de Direito de São Paulo ${ }^{139}$.

Em 1902, foi responsável pela criação do Instituto Disciplinar, instituição voltada para a recuperação de menores moralmente abandonados e delinquentes, inspirada nas novas concepções criminológicas ${ }^{140}$.

Em 1921, foi criada a Sociedade de Medicina Legal e Criminologia de São Paulo, importante marco institucional do desenvolvimento das ideias criminológicas nesse novo contexto político, com a pretensão de ser um espaço voltado para congregar médicos e juristas na discussão das questões referentes ao crime e à criminalidade, incluindo nomes como Oscar Freire, Alcântara Machado, Franco da Rocha, Flamíneo Fávero, Franklin Piza, Alfredo Issa Ássaly, entre muitos outros ${ }^{141}$. Também por influência das ideias criminológicas, foram criados laboratórios de Antropologia Criminal, como o da Polícia e o da Penitenciária do Estado.

\footnotetext{
${ }^{138} \mathrm{O}$ posicionamento de Anibal Bruno em matéria de periculosidade era extremo e ia além da fórmula de Ferri. Ele negava as correntes que defendiam a diversidade de sanções (penas para imputáveis e medidas de segurança a inimputáveis), que julgava inteiramente fora do espírito da teoria do estado perigoso, e entendia que não se poderia distinguir entre imputáveis e inimputáveis, mas sim entre perigosos e não perigosos. Assim, defendia medidas de "profilaxia da criminalidade" pré-delitivas para impedir que o homem viesse a delinquir. No entanto, não distinguia entre perigosidade pré ou pós-delito e o Estado não deveria esperar a ocorrência do delito para iniciar a ação preventiva. Ademais, adotava a perigosidade como critério de aplicação da pena. Num equivocado prognóstico, Anibal Bruno encerra sua obra profetizando "o projeto do Código Brasileiro promove, assim, um passo avançado no sentido dessa legislação do futuro, sem culpabilidade e sem pena, onde o objetivo da defeza social se atinge pelas medidas geraes de prevenção criminal e pela correção medico-pedagogica da personalidade do delinquente". BRUNO, Anibal. A perigosidade criminal, p. 160 (destaques nossos).

${ }^{139}$ Cf. PIMENTEL, Manoel Pedro. Breves notas para a história da Criminologia no Brasil, p. 139.

${ }^{140}$ Cf. ALVAREZ, Marcos Cesar. Op.cit., p. 143.

${ }^{141}$ Idem, ibidem, p. 144.
} 
Mas, é a partir da produção legislativa do início do século XX, que aquelas ideias passam a ganhar corpo. A legislação penal brasileira do século XX foi marcada sempre por um viés eclético, mas não se afastou, de qualquer maneira, dos principais postulados da Escola Positivista italiana e das ideias da Nova Defesa Social. Manteve a responsabilidade fundada no livre-arbítrio como critério de imputabilidade, mas acolheu, por outro lado, a perigosidade como fundamento das medidas de segurança. Com isso, acabou conciliando, a exemplo de outras legislações estrangeiras, os postulados da Escola Clássica com ideias preconizadas pelo positivismo criminológico e, especialmente, com as premissas da Escola da Defesa Social.

A grande marca dessa produção legislativa, no que concerne aos fins da pena e aos critérios de sua aplicação está na necessidade de defesa social contra a má índole do delinquente, ideia que permite que o subjetivismo, consagrado pela adoção da personalidade do agente como critério de aplicação da pena e pelo conceito de periculosidade, seja erigido a critério de incidência da lei penal.

\subsection{Legislação penal brasileira. Escorço histórico}

O Código Penal do Império, aprovado em dezembro de 1830, foi um diploma elaborado ainda sob a influência dos ideais do Iluminismo e da Revolução Francesa.

Segundo Francisco de Assis Toledo, o código de 1830, "ao lado das virtudes inegáveis que o ordenavam, exibia, contudo, alguns resíduos de uma sociedade escravocrata, que não abria mão de certos instrumentos de repressão, utilizados no passado". Dentre eles, a pena de morte pela forca, a pena de galés, o trabalho forçado, a pena de banimento do país, o degredo para lugar determinado e o desterro para fora do lugar do delito ou da principal residência do réu ou do ofendido ${ }^{142}$.

Mas o Código do Império foi motivo de críticas, não por esses aspectos, mas sim pelo seu caráter liberal que "se supunha ser responsável pelo recrudescimento da criminalidade. Assim, não tardou o surgimento de uma reação antiliberal que, durante a

\footnotetext{
${ }^{142}$ TOLEDO, Francisco de Assis. Princípios básicos de Direito Penal, p.59.
} 
vigência do novo estatuto, logrou editar algumas leis de cunho retrógrado, principalmente contra escravos" ${ }^{143}$.

No contexto da abolição da escravidão, do desmoronamento da monarquia e da proclamação da República no Brasil, é editado o Código Penal da República. Elaborado pelo Conselheiro Ministro Campos Sales, do Governo Provisório, foi entregue em outubro de 1890. Mal entrou em vigor, passam a surgir movimentos visando sua reforma. Muitas leis modificativas lhe são apresentadas e, em 1932, são concretizadas na Consolidação das Leis Penais e a ele incorporadas ${ }^{144}$.

Francisco de Assis Toledo aponta esse período como o mais sensível da ciência penal no Brasil, porquanto o país carecia de um bom Código Penal e, principalmente, de uma Ciência Penal que pudesse oferecer os métodos de pesquisa e os fundamentos científicos para a modernização da nossa legislação penal. Essa deficiência começaria a desaparecer "com o surgimento de uma nova plêiade de penalistas, atualizados com os autores italianos e alemães, dentre os quais se destacam, de modo especial, Galdino Siqueira, Costa e Silva e Nelson Hungria” ${ }^{145}$.

O Código de 1890 era de cunho clássico. Pierangeli afirma parecer ser sensível na sua estruturação a influência do Código italiano de 1889, o chamado Código Zanardelli. Esse, por sua vez, também teria sido duramente criticado, sobretudo por Lombroso e outros positivistas, pois, quando entrara em vigor, já se via atacado pelas novas ideias, porquanto era estruturado em princípios democráticos e liberais, fazendo poucas concessões às concepções positivistas ${ }^{146}$.

As tentativas de reforma do Código Penal de 1890 resultaram na elaboração de vários projetos de Código Penal. A necessidade da reforma da legislação penal era fato incontroverso, e as críticas à precariedade da legislação penal em vigor eram severas entre os penalistas ${ }^{147}$.

\footnotetext{
${ }^{143}$ Idem, ibidem, loc. cit..

${ }^{144}$ Idem, ibidem, passim.

${ }^{145}$ Idem, ibidem, passim.

${ }^{146}$ PIRANGELI, José Henrique. Códigos Penais do Brasil, p. 75.

${ }^{147}$ Idem, ibidem, p. 77.
} 
Uma primeira tentativa de reforma deu-se com o Projeto João Vieira Araújo, ainda em 1893. Alvo de inúmeras críticas, foi apresentado à Câmara dos Deputados, onde fora aprovado sem, contudo, obter seguimento no Senado ${ }^{148}$.

Seguiram-se, após cerca de uma década de resistência do Código Republicano, outros tantos projetos de lei, até a efetiva reforma do Código Penal brasileiro, que se daria em $1940^{149}$.

\subsubsection{Projeto Galdino Siqueira}

O Projeto elaborado em 1913 por Galdino Siqueira pretendia atender à já mencionada necessidade de reforma e preencher as lacunas na precisão de tipos penais e adequar a legislação à doutrina jurídico-científica.

A introdução ao Projeto, sob o título "Orientação do projeto - Sistema de classificação” deixava claro o posicionamento crítico com relação às ideias da chamada Escola Clássica, até então inspiradora da quase totalidade das legislações repressivas da época:

\footnotetext{
"Empregando o methodo methapysico, isto é, partindo de certos princípios apriorísticos tidos com verdades inconcussas, irrefragáveis - o livre arbítrio ou indeterminismo psychologico, existente igualmente em todos os homens mentalmente sãos, honestos ou criminosos, a idéa da justiça absoluta, que exige a proporção entre o castigo e o mal cometido, construiu inteiramente abstrata, fora do influxo, das injuncções da vida real. Por isso mesmo que o livre arbítrio, base fundamental da responsabilidade criminal, existe igualmente em todos os
}

\footnotetext{
${ }^{148}$ Idem, ibidem, loc. cit..

${ }^{149}$ Pierangeli anota que, assim como na Itália, “os movimentos positivistas pleiteavam, desde logo, a reforma da legislação, mas, enquanto isso não ocorria, um grande número de leis penais extravagantes foi editado, procurando harmonizar a legislação que se fundamentava na Terza Scuola e na Escola Positivista, que se apresentavam prevalentemente na doutrina. As situações, como se constata, entre as duas legislações guardam grande similitude e, enquanto na Itália o Projeto Ferri, de 1920, também não lograva aprovação, a reforma de 1930, com o Código Rocco, trouxe consigo a vitória de ideias positivistas e idealistas aqui, em 1940, e, como se verá, essas ideias também se tornam vitoriosas, com a edição do novo Código”. Op. cit., p. 77.
} 
homens, a pessoa do delinquente foi posta á margem, convergindo toda a atenção para o crime, erigido, então, em entidade abstracta” ${ }^{150}$.

A ineficácia do método da Escola Clássica estaria explicada em razão de ter erigido o crime em entidade abstrata, fundando a responsabilidade criminal no livre arbítrio e tomando a pena como castigo moral, criando-se, na expressão de Galdino Siqueira, em estética aritmética de penalidade: "É bem de ver que com semelhante intuição, posta a ficção em logar da realidade, que impotentes seriam os esforços empregados para pôr um dique á onda da criminalidade ${ } 151$.

Daí, explica o projeto a necessidade de uma nova orientação que melhor salvaguardasse os interesses sociais em jogo, o que se alcançou com o incremento das ciências naturais e sociais. Galdino Siqueira apontava que a Escola Antropológica, de cunho positivista, inaugurada por Lombroso e desenvolvida por Ferri e Garofalo, contudo, teria incidido no mesmo vício unilateral, "offerecendo solução incompleta ao problema” 152 na medida em que deixava o crime em plano secundário, tido como manifestação do temperamento ou da temibilidade do criminoso, baseada sua responsabilidade no fato de viver em sociedade.

Assim, desde que autor físico da ação criminosa, são ou alienado mental, o delinquente torna-se responsável, independentemente do elemento subjetivo que o orientou na conduta. A pena, na orientação da Escola Antropológica, seria um meio defensivo da sociedade ${ }^{153}$.

E essa orientação era objeto de crítica no Projeto Galdino Siqueira:

\footnotetext{
“Evidentemente, assentando a responsabilidade penal somente sobre o elemento objetivo, o facto da convivência social, a escola anthropologica fére fundo a consciencia jurídica da actualidade, que vê na culpa, isto é, na responsabilidade
}

\footnotetext{
${ }^{150}$ Projeto de Código Penal Brazileiro, p. 10.

${ }^{151}$ Idem, ibidem, loc. cit..

${ }^{152}$ Idem, ibidem, p. 11.

${ }^{153}$ Idem, ibidem, loc. cit..
} 
pelo resultado produzido, a condição primordial da repressão. Além disso, torna assás precária a liberdade individual, sujeita ao arbítrio administrativo” ${ }^{154}$.

Também eram objeto de crítica as conclusões dos trabalhos de Lombroso a respeito do tipo do delinquente nato e os chamados aspectos antropométricos e os exageros a que chegou a doutrina do psiquiatra italiano. Não escaparam da critica de Galdino Siqueira o desenvolvimento daquela doutrina por Ferri, também crítico do trabalho de Lombroso.

Galdino criticou, ainda, o arbítrio administrativo, a supressão dos meios de defesa do processo criminal, o sistema de provas e as violações à liberdade individual decorrentes do método inaugurado pela Sociologia Criminal.

Como resposta a mais essa solução unilateral e subjetiva, comprometedora da liberdade individual, surgiria, então, uma necessária reação, representada, segundo Galdino Siqueira, pela União Internacional de Direito Penal, que preconizava, adotando um posicionamento moderado comparado ao dos criminólogos da Escola Positivista italiana, como baluarte da liberdade individual, o princípio nullum crimen sine lege. Além disso, investigando as causas do crime e mantendo o método técnico-jurídico da ciência dogmática do direito penal, teria "ligado a ciência do passado à do futuro, por uma transformação evolutiva" ${ }^{155}$.

A responsabilidade criminal, segundo essa orientação, estaria fundada na culpa, e não na responsabilidade social. A culpa pressupõe imputabilidade do agente e imputação do resultado. Além disso, não seria necessário admitir-se como pressuposto necessário o livre arbítrio.

De outro lado, a nova orientação da doutrina penal, ao observar o delinquente, o faz não partindo de um tipo antropológico, mas a partir de categorias de delinquentes, se não assinaláveis por seus caracteres físicos, ao menos por seus atos e tendências: criminosos momentâneos e criminosos por natureza, ou índole. Nota-se, já aqui, a marca subjetivista desse posicionamento.

\footnotetext{
${ }^{154}$ Idem, ibidem, loc. cit..

${ }^{155}$ Idem, ibidem, loc. cit..
} 
Assim os distinguia o autor do Projeto

“Os primeiros são aquelles cuja individualidade não se distingue essencialmente da média dos homens, e são levados à pratica do crime pelas circumstancias exteriores (criminalidade aguda). A inesperada miseria economica e os males que della resultam para a família, um lucro attractivo e uma occasião favorável (furto), a vergonha (infanticidio), uma injuria cruel (homicídio da esposa adultera), a excitação proveniente do abuso do alcool, podem levar ao crime indivíduos até então honestos. Os segundos são aquelles cuja individualidade, pelo contrario, prepondera sobre as circumstancias exteriores (criminalidade chronica). O crime resulta da indole, das disposições arraigadas do delinquente e nos revela a sua natureza intima: rudeza brutal, crueldade destituida de toda a sensibilidade, estupido fanatismo, descuidosa leviandade, invencível repugnancia ao trabalho, desregrada sensualidade, levam o agente por numerosas phases de transição a situações indubitavelmente psychopathicas”156.

Além disso, os criminosos por índole, segundo sua capacidade de cura, seriam divididos em corrigíveis e incorrigíveis. Essa distinção terá fundamental importância para a legislação penal, que aí encontraria os elementos necessários para individualizar a pena, ou adaptá-la precisamente aos diferentes delinquentes.

Também aqui se nota que a individualização da pena deverá tomar em conta, antes de tudo, o caráter do criminoso, com vistas à sua cura ou correção.

Nos termos do Projeto, as penas teriam finalidades distintas, conforme a categoria de delinquentes: aos criminosos ocasionais, apenas o efeito intimidativo (prevenção especial); ao criminoso por índole e corrigível, as penas de correção (casa de correção, multas, penas concernentes a direitos cívicos) e penas de segurança aos incorrigíveis (deportação, prisão perpétua ou por tempo indeterminado): “como se vê, todo o systema da execução penal assenta sobre a classificação dos delinquentes, individualizando-se a pena, de sorte a adaptá-la às categorias de delinquentes” ${ }^{157}$.

\footnotetext{
${ }^{156}$ Idem, ibidem, p. 17.

${ }^{157}$ Idem, ibidem, p. 18.
} 
O Projeto também pretendia a aplicação da sentença criminal indeterminada, absoluta ou relativamente, segundo se tratassem de delinquentes de índole incorrigíveis ou não.

Importante tema presente no Projeto Galdino Siqueira era a questão da reincidência. Nos termos do Projeto, a reincidência era sinal do caráter do criminoso e, destarte, poderia demonstrar um caráter mais temível, mais perigoso, como poderia demonstrar o contrário. Caberia, portanto, examinar em cada caso se a recaída no delito seria resultado das tendências, do hábito ou se, ao contrário, seria resultado de circunstâncias alheias. Não passavam despercebidas para o autor que as condições socioeconômicas se constituíam em fato gerador da reincidência. De outro lado, as tendências más do condenado e sua índole poderiam também constituir sua causa.

O Projeto não admitia a obrigatoriedade do agravamento da pena em razão da reincidência, que apenas seria considerada caracterizada, autorizando penalidade especial, desde que o agente, depois de sentença transitada em julgado, cometesse outro crime e viesse a mostrar-se perigoso de modo especial à ordem pública e à segurança das pessoas.

A atualidade do Projeto Galdino Siqueira é notável, se observar-se que foi elaborado ainda em época na qual as ideias da Escola Positivista italiana frutificavam nas legislações penais dos mais diversos países. Mesmo inserido naquele contexto histórico, o autor do Projeto não se distanciou dos princípios da Escola Clássica, muito por conta do posicionamento da Escola de Von Liszt, que assumiu ter adotado.

Contudo, fica claro das linhas do Projeto o seu corte subjetivista. A índole do acusado foi erigida a fator que explica a prática do crime. Seu caráter assume relevada importância para o ajustamento da pena, que deveria ser aplicada segundo critérios de possibilidade de cura e correção do delinquente. Todo o sistema encontra-se ancorado na classificação de delinquentes, segundo sua maior ou menor tendência para delinquir. Sua perigosidade ganha especial importância para fins de reincidência.

O Projeto Galdino Siqueira não chegou a ser objeto de deliberação pelo Poder Legislativo. 


\subsubsection{Projeto Virgílio de Sá Pereira}

Após nova tentativa fracassada de reformar o Código Penal em vigor por meio do Instituto da Ordem dos Advogados do Brasil, em 1916, o Governo Arthur Bernardes incumbiu o desembargador Virgílio de Sá Pereira da elaboração de um novo projeto. A parte Geral do Projeto foi publicada em 10 de novembro de 1927 e, em 23 de dezembro de 1928, foi apresentado o Projeto completo ${ }^{158}$.

O retrocesso com relação ao projeto de Galdino Siqueira nota-se desde a falta de precisão de conceitos e da precariedade de exposição das ideias, à concepção de responsabilidade criminal e imputabilidade - tema tão lucidamente tratado pelo autor do projeto anterior - passando por inúmeras discussões confusas e carentes de tecnicidade, como a discussão a respeito da punibilidade da tentativa.

Para Sá Pereira, imputáveis e inimputáveis deveriam ser igualmente apenados, baseando-se nos princípios de defesa social:

\footnotetext{
"Sob o ponto de vista da defesa social, a razão que há para sujeitar à repressão os imputáveis é a mesma que impõe a prevenção aos inimputáveis. (...) A necessidade de defesa é a mesma nos dous casos, os meios de executá-la é que variam. Para uns, a repressão, para outros, a prevenção, mas ambas, dentro no direito penal, porque a função preventiva não repugna à natureza da pena” ${ }^{159}$.
}

Assim justificada na necessidade de defesa social, a internação do louco, para Sá Pereira, deveria ser compulsória na hipótese de ter cometido algum crime. Já para os casos de responsabilidade restrita ou diminuída não se justificava a diminuição da pena:

\footnotetext{
"Seria um contrassenso diminuil-a quando todos reconhecem tratar-se, justamente, sob o ponto de vista da defesa social, dos delinquentes mais perigosos. Nem seria justo fazel-o em atenção á sua anormalidade, porque estas não os priva da faculdade de determinar-se por motivos razoáveis, apenas a diminue ou debilita; nem os inibe de realizar o processo mental de associação
}

\footnotetext{
158 PIERANGELI, José Henrique. Op. cit., p.76.

${ }^{159}$ Projeto de Codigo Penal Brasileiro. Exposição de Motivos sobre a Parte Geral, p. 65.
} 
das idéas segundo o qual, a seu crime, como causa, se ligará a pena, como effeito $^{160}$.

Em seu projeto previa-se, ainda, a pena de relegação:

\begin{abstract}
“Em todo código deve haver, ao menos, uma pena eliminatória. Da única que realmente é - a de morte - não temos que cogitar, porque a Constituição no-lo veda. Restariam as penas perpetuas. Num systema, como o do projecto, em que se tenha na devida conta a personalidade do delinquente, somente aos incorrigíveis taes penas poderiam ser impostas" ${ }^{161}$.
\end{abstract}

O Projeto trazia a pena de relegação condicional (com encaminhamento às colônias penais) imposta ao criminoso por tendência, e o agravamento da pena para o reincidente. Também, juntamente com a pena de prisão superior a cinco anos, estava prevista a relegação:

\footnotetext{
"Se, da natureza do crime, das condições em que elle se commeteu, e da personalidade do delinquente se patenteia a sua temibilidade, o juiz togado, na mesma sentença, em que condemnar á prisão por mais de cinco anos, também o condemnará á relegação condicional. Este limite de tempo é desnecessário, tratando-se de reincidentes ou habituaes” ${ }^{162}$.
}

Os critérios para fixação da pena adotados pelo Projeto permitem reconhecer a adoção da finalidade de defesa social e a finalidade preventiva especial da pena. Surge, pela primeira vez, como critério subjetivo de aplicação da pena, a personalidade do agente:

\footnotetext{
Art. 129 - Attenderá o juiz, fixando a pena:

$1^{\circ}$ - á gravidade do crime e ao abalo social que elle causa;

$2^{\circ}$ - ao damno material e moral que produz;

$3^{\circ}$ - á personalidade do delinquente e ao perigo social que ella exprime;

$4^{\mathrm{o}}$ - aos motivos que o determinaram;

$5^{0}$ á importância de sua participação no crime.
}

\footnotetext{
${ }^{160}$ Idem, ibidem, p. 78.

${ }^{161}$ Idem, ibidem, p. 104.

${ }^{162}$ Idem, ibidem, p. 105.
} 
Os critérios objetivos e subjetivos adotados para a fixação da pena (personalidade e perigosidade), segundo o autor do Projeto, justificavam-se pela recusa em adotar-se um critério exclusivo. Contudo, Sá Pereira deixa claro que a recusa em adotar a personalidade como critério exclusivo de fixação da pena deve-se menos ao seu posicionamento pessoal, que à “repugnância da consciência popular pela predominância deste critério”:

\footnotetext{
“Estaríamos no terreno clássico, tradicional, popular, quando exclusivamente bitolássemos a pena pela gravidade objetiva do crime, mas a defesa social teria sido sacrificada; a esta atenderíamos quando elegêssemos por critério exclusivo a personalidade do delinquente, mas inútil insistir sobre a repugnância da consciência popular pela predominância deste critério” ${ }^{\text {163 }}$.
}

O Projeto seguiu, declaradamente, o modelo do Projeto Rocco italiano, de 1927, cujo art. 134 preconizava medir-se a pena não só pela gravita del reato, como pela malvagità e periculosità del colpevole.

Não se extrai da redação do Projeto uma expressa predileção por uma escola ou uma corrente penal, mas antes uma evidente confusão decorrente da adoção de conceitos, muitas vezes conflitantes, de uma e outra escola.

De qualquer forma, não são poucas as menções à ideia de defesa social, temibilidade, perigo social e à personalidade do criminoso, o que nos leva a concluir que os preceitos que mais inspiraram Virgilio de Sá Pereira foram os da Escola Positivista italiana e da Defesa Social.

O subjetivismo também parecia muito mais claro e absorvido pelo projeto do que no lúcido Projeto Galdino Siqueira e ganha especial relevância no que atinge às circunstâncias modificadoras da pena, que seriam sempre de caráter subjetivo:

\footnotetext{
“As circunstâncias modificadoras da pena são em geral de caracter subjetivo, o que conforma com a orientação geral do Projecto impregnado de subjectivismo, e lhe mereceu os louvores de autoridades, como Jiménez de Asúa”164.
}

\footnotetext{
${ }^{163}$ Idem, ibidem, p. 115.

${ }^{164}$ Idem, ibidem, p.117.
} 
É esse subjetivismo que é valorizado na fixação da medida da pena. A personalidade do acusado surge, assim, como critério que, ao lado da gravidade do delito (critério objetivo), deveria orientar o juiz, a quem a legislação deveria outorgar suficiente liberdade de ação para, de acordo com essa personalidade, individualizar a pena:

\begin{abstract}
“As ações humanas, e o crime é uma delas, não se podem apreciar in abstrato, precisamos sempre referil-as à personalidade de quem as cometeu e ás circunstancias em que foram cometidas. Só o juiz tem o caso concreto sob os olhos; soménte elle, portanto, poderá ajustar a pena á personalidade do delinquente. Guiando-se pelo critério subjectivo, elle individualizará a pena que o legislador, guiando-se pelo critério objetivo, havia generalizado”165.
\end{abstract}

A análise subjetiva também funcionava como critério de interpretação para o fenômeno da reincidência. Enquanto que, para os adeptos da Escola Clássica, a reincidência referia-se a um fenômeno extrínseco, que poderia vir a agravar a pena, na concepção do Projeto, Sá Pereira afirmava que a reincidência é circunstancia propriamente intrínseca, que toca ao elemento subjetivo do crime, ao agente mesmo e, por essa razão, aumenta a imputação:

\footnotetext{
"Ella será ou deixará de ser, segundo as circumstancias, reveladora da periculosidade do delinquente. Se não revela maior perigo social, nenhuma influencia deverá exercer para modificar a pena. Para que elle adquira significação expressiva aos olhos do legislador penal, é mister situa-lo no meio das circumstancias em que se consumou e referi-lo á personalidade de quem por sua autoria responde" ${ }^{, 166}$.
}

Os elementos de natureza objetiva serviriam apenas para evidenciar a materialização da reincidência, mas as consequências de sua caracterização no caso concreto estavam condicionadas à constatação de ela ser ou não um índice de maior perigo social. Dessa maneira, o Projeto Sá Pereira consagrava o critério antropológico da reincidência, a exemplo do que ocorria também com o Projeto Rocco italiano.

\footnotetext{
${ }^{165}$ Idem, ibidem, loc. cit..

${ }^{166}$ Idem, ibidem, p. 122.
} 
Assim, a reincidência apenas gerava consequências para o autor desde que, entre o primeiro fato criminoso e o segundo, estivesse presente a mesma predisposição, a mesma tendência inerente à personalidade do delinquente.

O Projeto Sá Pereira foi duramente criticado e também não alcançou aprovação legislativa. Foi submetido à comissão revisora composta pelo próprio autor e Evaristo de Morais e Bulhões Pedreira. Foi apresentado à Câmara dos Deputados, onde chegou a ser aprovado. Ao ser remetido ao Senado, encontrava-se na Comissão de Justiça quando sobreveio uma nova ordem política, o golpe de Estado de 1937.

\subsubsection{Projeto Alcântara Machado}

Com a instalação do chamado "Estado Novo”, em novembro de 1937, confiou-se a Alcântara Machado a incumbência de elaborar um novo projeto de Código Penal. O projeto da parte geral foi entregue pelo professor da Universidade de São Paulo em maio de 1938 e a parte especial, em agosto do mesmo ano ${ }^{167}$.

A Exposição de Motivos do anteprojeto da Parte Geral do Código Criminal Brasileiro elencava os inúmeros motivos que levaram o autor a elaborar um projeto integralmente novo.

A respeito da modificação das circunstâncias sociais da época da elaboração do projeto de Sá Pereira e o que estava a apresentar, Alcântara Machado afirmou:

\footnotetext{
“Os movimentos subversivos de 1935 patentearam a gravidade e a extensão dos perigos a que nos expunha a deficiência do nosso aparelhamento repressivo. A Constituição de 10 de novembro deu nova estrutura ao Estado e novo sentido à política nacional, tornando imperiosa a mudança das diretrizes penais. Reforçar a defesa coletiva contra a criminalidade política são imperativos a que não pode fugir o legislador em paizes organizados da maneira por que atualmente se encontra o nosso" ${ }^{\text {168 }}$.
}

${ }_{168}^{167}$ Cf. TOLEDO, Francisco de Assis. Op. cit., p.62 
A influência da legislação penal italiana é clara nas citações do seu autor, ainda na Exposição de Motivos. Ao mencionar as justificativas para o título “Código Criminal Comum”, menciona as observações de Giavanotich sobre o Código Rocco: a denominação de um “Código Penal” estaria em contradição com o conteúdo, toda vez que as medidas de segurança ocupassem no texto legislativo lugar de importância igual ao das penas: “Antes de tudo, o Código não se ocupa somente de penas, mas também de medidas de segurança que não têm caráter punitivo” ${ }^{169}$.

O título III do anteprojeto, denominado "Do agente”, trazia, além de outras, as penas previstas a diversos tipos de agente distintos, incluindo-se os loucos autores de crimes.

O título também definia os tipos de criminosos, distinguindo o criminoso de ocasião, por tendência, o reincidente e o habitual. Segundo a Exposição de Motivos, mereceria pena agravada aquele que demonstrasse maior tendência para a delinquência, justificada na má índole do agente:

\footnotetext{
"Reincidência, habitualidade e tendência a delinquir são tratadas severamente, por isso que denunciam, no dizer do criminalista famoso, um estado mais profundo, permanente, orgânico do agente. A primeira é de fácil verificação. As outras dependem do estudo minudente e acurado da personalidade do criminoso; e por isso mesmo é preciso cercar de cautelas a sua verificação, dada a gravidade das consequências que resultam da classificação do delinquente em qualquer das mencionadas categorias. Daí a exigência do pronunciamento do tribunal superior, em recurso necessário; daí a exigência de quorum maior para a declaração" ${ }^{170}$.
}

A definição do criminoso por tendência encontrava-se no art. 21 do anteprojeto, assim redigido:

Art. 21 - Haver-se-á como criminoso por tendência aquele que demonstrar notável perversão moral, por seu comportamento anterior, concomitante ou

${ }^{169}$ Ibidem, p. 204.
${ }^{170}$ Ibidem, p. 213. 
subsequente a um crime doloso de perigo comum ou contra a integridade pessoa ou a vida. Não se haverá, todavia, como tal quem tiver cometido o crime nas condições do art. $16 \mathrm{n}$. IV.

Criminoso habitual, nos termos do Projeto, seria aquele que, condenado no Brasil ou no estrangeiro por três ou mais crimes dolosos, cometesse novo crime não culposo, punido com reclusão ou detenção, dentro dos 10 anos seguintes à data do último dos crimes precedentes. Não havia qualquer menção ao trânsito em julgado das condenações, bastando para a constatação da habitualidade a existência de condenação criminal.

Em matéria de pena, o Projeto Alcântara Machado declarava-se adepto do Código Italiano, adotando a concepção dualista, com a adoção de penas e medidas de segurança como institutos diferentes em seus fundamentos, natureza e objetivos. Nesse âmbito, as medidas de segurança seriam adotadas como medidas administrativas que serviriam tão somente para defender a sociedade contra o perigo representado por determinadas pessoas, em razão de suas condições subjetivas. A influência do trabalho de Alfredo Rocco no tema de medidas de segurança é nota literal da Exposição de Motivos.

No que concerne aos fins da pena e à sua aplicação, o Projeto era claro ao enunciar a finalidade de prevenir o crime e tratar o criminoso de acordo com sua maior ou menor periculosidade. E, para a fixação da pena aplicável, o juiz deveria atender, em primeiro lugar, à personalidade do agente:

\footnotetext{
Art.43-(...)

$\S$ único - no exercício desses poderes o juiz atenderá:

I - à personalidade do agente;

II - às circunstâncias que agravam ou atenuam a pena;

III - às causas de aumento ou diminuição.
}

Nenhum outro critério de natureza objetiva relacionado ao fato praticado estava relacionado dente os critérios de fixação da pena. Para individualizá-la à personalidade do criminoso, caberia ao juiz anteder a algumas diretrizes relacionadas à subjetividade do acusado, assim relacionadas no art. 44 do Projeto: 
Art. 44 - Para formar juízo sobre personalidade do agente, o juiz terá em conta: I - a idade, educação e situação econômica do réo, os seus antecedentes judiciais ou penais e procedimento na vida individual, familiar e social;

II - o seu comportamento e estado de ânimo antes, durante e depois do crime;

III - quaisquer outros elementos que contribuam para o conhecimento de seu temperamento e caráter.

Em outros termos, caberia ao juiz, segundo a fórmula do inciso III, do art. 44, avaliar a personalidade do criminoso com base no seu comportamento e no seu caráter, na sua maneira de agir no meio familiar, social e em sua vida particular; investigar seu estado de ânimo antes, durante e depois do crime. Com isso, o Projeto Alcântara Machado consagrou de forma definitiva o subjetivismo que, aos poucos, já vinha ganhando espaço nos Projetos de Código Penal anteriores.

O Projeto, no entanto, veio a ser submetido a um curioso e polêmico processo de revisão, para o qual foi instituída comissão revisora integrada por Vieira Braga, Nelson Hungria, Narcélio de Queiroz e Roberto Lyra.

É notória a discórdia que se estabeleceu entre o autor do Projeto e os membros da comissão de revisão, sobretudo porque foi manifestada pelo próprio professor Alcântara Machado, a respeito das significativas modificações que foram feitas ao texto original e que, segundo o Ministro Francisco Campos, seriam meras alterações, sem a intenção de colaborar mais profundamente na obra realizada por Alcântara.

Uma das maiores críticas de Alcântara foi o fato de ter sido o trabalho de revisão feito a "portas e janelas cerradas”. Foi mantido em segredo por cerca de um ano e lhe veio ao conhecimento a própria existência de uma comissão revisora por meio de comentários da imprensa.

Ao descrever o trabalho realizado pelos membros da comissão revisora, Alcântara Machado anunciava, ironicamente: “veremos oportunamente, como, por um passe de mágica, se transformaram em autores exclusivos os simples colaboradores”. O tom de revolta era notável: 
“O que me foi presente, com o rótulo de 'Código Penal do Brasil', era na realidade um decalque do Código Criminal Brasileiro, projetado por mim. Este reaparecia naquele, por mais que tentasssem refigurá-lo, mediante graves mutilações, enxertos insignificantes e emendas anódinas ou contraproducentes de redação” ${ }^{171}$.

Alcântara alegou que se deu à "trabalheira insana” de analisar todo o substitutivo e compará-lo ao trabalho por ele elaborado, apenas porque o Presidente da República, à época, lhe teria perguntado sobre o andamento do trabalho e incitando-o a prosseguir na tarefa. Após a referida análise, submeteu o texto final desse trabalho comparativo ao Governo, endereçado ao Ministro Francisco Campos. E, apresentando o cotejo que elaborou entre os dois textos, criticou:

"Se vê desde logo pelo simples cotejo dos textos, a revisão obedeceu, toda inteira, à preocupação de mutilar, desfigurar, deturpar o projeto, de maneira a tornar imperceptível a sua influência na futura codificação, e a justificar a informação insistentemente divulgada de que a comissão revisora se transformara ‘ex próprio Marte’ em comissão organizadora da reforma penal”172.

As severas críticas ao substitutivo apresentado pela comissão revisora foram especialmente contundentes a respeito do Capítulo referente à classificação dos criminosos:

\footnotetext{
“Não se contenta o substitutivo com estropiar a linguagem do projeto que, no tocante à correção, clareza e simplicidade, recebeu elogios unânimes dos entendidos. Atacou-lhe a estrutura, mutilando-a, às cegas, no que tinha de melhor. (...)

Suprimiram-se também os dispositivos referentes à classificação dos criminosos, classificação indispensável ao tratamento penal. É postulado moderno che el criterio fundamentale per la sceita dela pena o, píu largamente, del mezzo defensivo idôneo (sanzione criminale) eia quello di ripartire i delinquente in classi, ala atregua dela lero particolare personalitá ( Florian, II, n. 789)”173.
}

\footnotetext{
${ }^{171}$ Para a história da Reforma Penal Brasileira, p. 26.

${ }^{172}$ Idem, ibidem, p. 28.

${ }^{173}$ Idem, ibidem, p. 34.
} 
Entregue o manifesto comparativo de Alcântara Machado ao Ministro Francisco Campos, este solicitou que redigisse novamente o projeto, corrigindo-o nos tópicos que julgasse passíveis de melhoria e aproveitasse o que entendesse conveniente. Assim, Alcântara refundiu a Parte Especial, publicando a "Nova Redação do Projeto do Código Criminal Brasileiro".

Ao final, a comissão novamente reencetou a revisão, também em sigilo, sendo publicado o Código Penal de 1940 com nova Exposição de Motivos, em 31 de dezembro de $1940^{174}$.

\subsubsection{Código Penal de 1940}

Dos trabalhos da revisão do Projeto Alcântara Machado foi editado o novo Código Penal, pelo decreto 2.848, de 07 de dezembro de 1940, que entrou em vigor em janeiro de 1942.

A Exposição de Motivos declarava expressamente a recusa da comissão pela adoção de ideias exclusivas de uma só escola penal, anunciando que "os postulados clássicos fazem causa comum com os princípios da Escola Positiva”.

Contudo, é de se reconhecer que o Código de 1940 "possuía uma maior concessão ao positivismo do que às ideias de Carrara e ao neoclassicismo" ${ }^{175}$. A adoção das

\footnotetext{
${ }^{174}$ Sobre o trabalho da Comissão revisora, Candido Mota Filho manifestou: "Ainda um ponto que o anteprojeto tinha aberto uma vereda para novas conquistas para a ciência criminal e para a eficácia da política criminal: a classificação dos delinquentes. Se é bem certo que já não podíamos ficar nos excessos do positivismo jurídico, quando afirmou que não há delinquência mas delinquentes; se é bem certo, hoje em dia, que o delito é visto através do ato do delinquente; é certo também que não se pode desdenhar uma certa classificação, necessária, indispensável para reduzir às incertezas da pena indeterminada, às distribuições das medidas repressivas e reeducativas para se medir em seu justo sentido aquilo que se entender por individualidade da pena". Alcântara Machado e o novo Código Penal, p. 13.

Fica claro que Candido Mota não se havia entusiasmado com a classificação dada pelo anteprojeto em relação aos criminosos de ocasião e os criminosos por tendência. De qualquer forma, entendeu que a comissão revisora andou mal em retirar a classificação na revisão do projeto. Para ele, uma classificação mínima que fosse deveria ser mantida, pois "uma classificação prática é possível e não se faz política criminal rigorosamente científica sem uma classificação de delinquentes”. Idem, ibidem, p. 19-20.

Ainda segundo Candido Mota, Alcântara Machado justificava a pretensão de denominar o novo Código de "Código Criminal” exatamente porque previa, apoiando-se nos "mestres italianos", as medidas de segurança, que seriam verdadeiras reações contra "os deficientes, os insuficientes e os doentes" que "ameaçam a tranquilidade social”.
} 
medidas de segurança, baseadas na periculosidade e a implementação do sistema do duplo binário garantem a certeza desta afirmação.

A pena foi adotada com finalidade retributiva e intimidante. As medidas de segurança, como medidas de prevenção e assistência social relativamente ao estado perigoso daqueles que, fossem ou não penalmente responsáveis, praticassem ações previstas na lei como crime. A Exposição de Motivos do CP de 1.940 anunciava as razões da adoção das arbitrárias medidas de segurança, revelando os traços das ideias positivistas e de defesa social, já tão difundidas em outras legislações penais à época ${ }^{176}$ :

\begin{abstract}
"É notório que as medidas puramente repressivas e propriamente penais se revelaram insuficientes na luta contra a criminalidade, em particular contra as suas formas habituais. Ao lado disto existe a criminalidade dos doentes mentais perigosos. Estes, isentos de pena, não eram submetidos a nenhuma medida de segurança ou de custódia, senão nos casos de imediata periculosidade. Para corrigir a anomalia, foram instituídas, ao lado das penas, que têm finalidade repressiva e intimidante, as medidas de segurança. Estas, embora aplicáveis em regra post delictum, são essencialmente preventivas, destinadas à segregação, vigilância, reeducação e tratamento dos indivíduos perigosos, ainda que moralmente irresponsáveis” (Exposição de Motivos do Código Penal de 1940).
\end{abstract}

No sistema do novo Código, as medidas de segurança tinham como pressupostos cumulativos a prática de um fato previsto como crime e a periculosidade do agente, sendo

\footnotetext{
${ }^{175}$ PIERANGELLI, José Henrique. Op. cit., p. 81.

${ }^{176}$ As medidas de segurança foram pela primeira vez objeto de sistematização com o anteprojeto de CP suíço (1893). Esse sistema foi adotado, posteriormente, pelo Código Penal Suíço de 1937. As medidas de segurança aparecem na lei portuguesa de 1896, no Código Penal norueguês, de 1902 e no Código Penal argentino, de 1921. Mas foi com o Código Penal italiano, de 1930, que surge na legislação um sistema completo de medidas de segurança que acabou difundindo-se amplamente nos códigos promulgados a partir de então. Cf. FRAGOSO, Heleno Cláudio. Sistema do duplo binário: vida e morte, p. 2-3.

Na Espanha, a Ley de Peligrosidad y Rebabilitación Social (LPRS) estabelecia, em seu artigo 2º a aplicação de medidas de segurança e de reabilitação para aqueles que apresentassem uma "peligrosidad social", incluindo-se, neste conceito, "Ios vagos habituales, los que habitualmente ejerzan, promueven, favorezcan o faciliten la prostituición, así como los dueños, empresarios, gerentes, administradores e encargados de locales o estabecimientos, abiertos o no al público, em los que, com su conocimiento, se realicen indicadas actividades; los que promuevens, favorezcan o faciliten la producción, tráfico, comercio o exhibición de cualquier material pornografico o hagan apología, aós como los que realicen actos de exhibicionismo que atentena la moral, y los dueños, empresarios, gerentes, administradores o encargados de locales o estabelecimientos, abiertos o no al público, em los que, con su conocimientos tengan lugar actividades las expresadas; los mendingos habituales y los que viven de la mendicidad ajena o explotaren com tal fin a menores, enfermos, lisiados o ancianos (...)” DÍAZ-MAROTO Y VILLAREJO. Op. cit., p. 455.
} 
aplicáveis tanto a imputáveis quanto a inimputáveis. Ao imputável, deveriam ser aplicadas após o cumprimento da pena, como medida complementar ressocializadora.

Ao contrário das penas de caráter retributivo e aflitivo, comportavam um sentido de tratamento assistencial, medicinal e pedagógico. As finalidades das medidas de segurança, nesse contexto, eram a recuperação social e a neutralização do criminoso.

Nelson Hungria foi grande defensor das medidas de segurança para os chamados criminosos habituais ${ }^{177}$. Com essa denominação, designava aqueles criminosos que retornavam à criminalidade em razão de sua personalidade deformada, para os quais a reforma por meio da pena (castigo) era precária.

\begin{abstract}
"Inspiradas no correcionalismo de Röder e nas conclusões da Escola Positiva, surgiram, então, no campo da luta contra o crime, as medidas de segurança: ao invés da pena-castigo, ou em complemento a esta, devia-se adotar um sistema de prevenção especial, uma técnica de regeneração ou de cura social, a que deveriam ser submetidos, sem limite apriorístico no tempo, os delinquentes perigosos em geral e, em particular, os habituais” ${ }^{178}$.
\end{abstract}

Hungria procurava ressaltar as diferenças entre penas e medidas de segurança, sobretudo com relação às suas finalidades ${ }^{179}$ :

a) o criminoso habitual deve ser prevenido já no reincidente simples ou mesmo no primário, cuja vida pregressa e a personalidade façam presumir o futuro habitual;

b) não deve ser abolida a sua submissão à pena tradicional, mas esta tem de ser complementada por um regime específico de ressocialização, sem qualquer

\footnotetext{
177 Embora publicamente rejeitasse as ideias lombrosianas sobre a constituição psicobiológica e antropológica do delinquente, não se nega a influência das principais ideias do positivismo de cunho social no pensamento de Nelson Hungria. Ele foi um grande defensor das medidas de segurança como solução da criminalidade, com especial ênfase no seu caráter ressocializador e curativo e, sobretudo, do sistema do duplo binário, no qual enxergava uma medida de complementação da pena com a finalidade da reeducação moral do delinquente, sua preparação moral e material para uma vida digna e útil em sociedade.

${ }^{178}$ Comentários ao Código Penal. Apêndice. Criminosos habituais, p. 354.

${ }^{179}$ Na prática, no entanto, essa diferenciação nunca foi alcançada. Conforme relata Heleno Fragoso, "no Estado de São Paulo foi construído um único estabelecimento para a execução de medidas de segurança detentiva para imputáveis. Em nenhum outro Estado existem tais estabelecimentos, o que significa que as disposições do Código ficaram no papel”. Op. cit., p. 15.
} 
caráter aflitivo (pelo menos do ponto de vista psicológico), em estabelecimentos especiais, inteiramente distintos da penitenciária;

c) para o tratamento individualizado, deve-se distinguir e separar, quando necessário, entre os habituais de fundo psicopático e os de constituição psíquica e normal;

d) a duração do tratamento, adequadamente curativo ou reeducativo, será indefinida, isto é, condicionada à persistência do peculiar estado perigoso dos internados;

e) à desintegração deve seguir-se um regime de provida tutela do indivíduo, até que se possa razoavelmente inferir o seu definitivo ritmo com a pauta normal da vida em sociedade.

A adoção do sistema do duplo binário, caracterizado pela aplicação da medida de segurança complementarmente à aplicação da pena, decorreu da convicção de que, para indivíduos reincidentes ou habituais, a pena retributiva não se mostrava suficiente para os fins de recuperação e defesa da sociedade. Para as exigências da defesa social frente aos delinquentes mais perigosos, a pena não bastava.

O juízo de periculosidade é a questão mais tormentosa relacionada às medidas de segurança. Por tratar-se de um juízo sobre o possível comportamento futuro do indivíduo, não admite critérios nem fórmulas positivas ou científicas. É, a bem da verdade, um juízo de adivinhação. Nas palavras de Heleno Fragoso, “em boa verdade, o juízo de periculosidade é formulado precariamente pelo juiz, de forma empírica, incerta e intuitiva, mais semelhante a uma suspeita que a um diagnóstico positivo (...) a verdade é que ninguém sabe quando a periculosidade existe ou não existe” ${ }^{180}$.

O artigo 77 do Código Penal de 1.940 estabelecia critérios para a avaliação da periculosidade basicamente semelhantes aos critérios para a individualização da pena (personalidade, antecedentes, motivos e circunstâncias do crime), voltados, no entanto, a um juízo de prognóstico de reincidência.

${ }^{180}$ Idem, ibidem, p. 12. 
Mas o Código também previa hipóteses em que a periculosidade era presumida pela lei, prescindindo da já tão frágil análise judicial, cabendo ao juiz impor a medida de segurança quando verificadas uma das hipóteses do artigo 78:

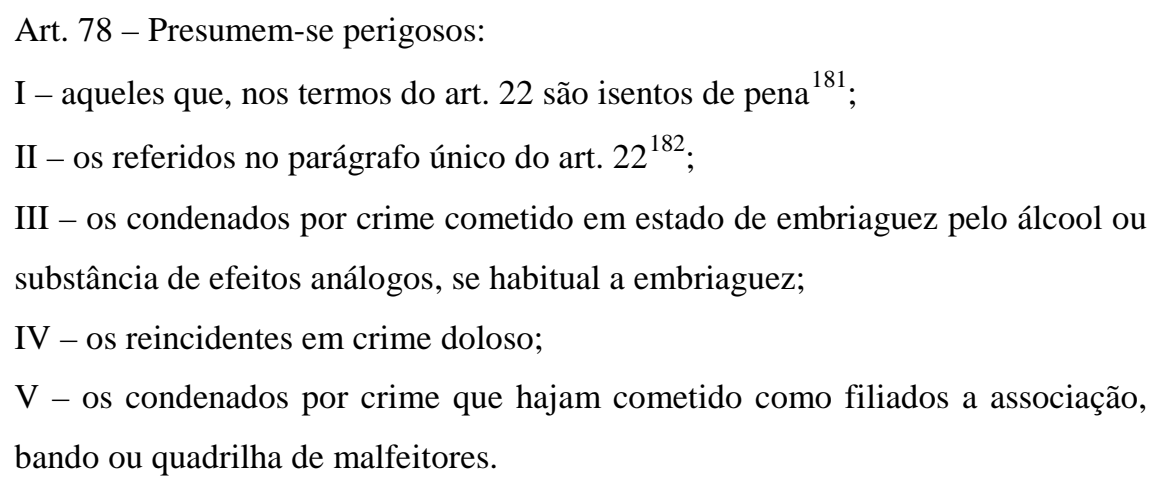

A presunção legal de periculosidade, portanto, permitia a segregação do indivíduo sob o estigma de perigoso, sendo o elemento "reincidência” o grande recordista de indicativo de periculosidade para os fins de aplicação da medida de segurança.

No que se refere à aplicação da pena, a disposição do art. 42 do Código Penal de 1940 viria a traçar o caminho da legislação atual, marcando a lei penal com o traço subjetivista que já vinha se consolidando nos ensaios de Código Penal anteriores ${ }^{183}$.

Pela primeira vez, no Código Penal brasileiro, a personalidade do agente surge como critério de aplicação da pena e, seguindo a linha do pensamento jurídico-penal que vinha se consolidando desde o século XIX, foi interpretada pela grande maioria dos doutrinadores da época como seu principal critério de fixação.

O art. 42 do Código Penal de 1940, quase que com a mesma redação do vigente Código Penal (art. 59) dispunha:

\footnotetext{
${ }^{181}$ Art. 22 - É isento de pena o agente que, por doença mental ou desenvolvimento mental incompleto ou retardado, era, ao tempo da ação ou omissão, inteiramente incapaz de entender o caráter criminoso do fato ou de determinar-se de acordo com esse entendimento.

${ }^{182}$ Parágrafo único. A pena pode ser reduzida de um a dois terços, se o agente, em virtude de perturbação da saúde mental ou por desenvolvimento mental incompleto ou retardado, não possuía, ao tempo da ação ou da omissão, a plena capacidade de entender o caráter criminoso do fato ou de determinar-se de acordo com esse entendimento.

${ }^{183}$ A Exposição de Motivos ressaltava: Na aplicação da pena, o projeto dá ao juiz grande latitude de apreciação. Entre o mínimo e o máximo, ele graduará a quantidade da pena de acordo com a personalidade e os antecedentes do criminoso, os motivos determinantes, as circunstâncias e as consequências do crime.
} 
Art. 42 - Compete ao juiz, atendendo aos antecedentes e à personalidade do agente, à intensidade do dolo ou grau da culpa, aos motivos, às circunstâncias e consequências do crime:

I - determinar a pena aplicável, dentre as cominadas alternativamente;

II - fixar, dentro dos limites legais, a quantidade de pena aplicável.

Os Códigos Penais dos países da América Latina, via de regra, adotaram um modelo legislativo diretamente influenciado pela Escola Positivista italiana, “mais propriamente uma tendência periculosista e defensista" ${ }^{184}$, guiando-se por uma tendência preventivo-especial quanto às finalidades da pena ${ }^{185}$.

Sob tais diretrizes, revela-se um sistema penal cujos critérios de punibilidade - e não apenas de individualização da resposta penal - não se baseiam unicamente no fato praticado, mas no modo de ser do agente, perquirindo de suas condutas anteriores e suas motivações interiores, partindo, fundamentalmente, da ideia do criminoso como ser perigoso.

O conceito de periculosidade criminal e a ideia de necessidade da defesa da sociedade ingressariam, a partir de então, de forma contundente na legislação penal brasileira. A defesa da sociedade contra os delinquentes perigosos e irrecuperáveis serviram de justificativa para a adoção de um sistema que levou a um encarceramento e um rigor repressivo sem precedentes.

O rigor repressivo implementado pelo novo Código também foi assinalado por Assis Toledo, que criticava:

“É um estatuto de caráter nitidamente repressivo, construído sobre a crença da
necessidade e suficiência da pena privativa de liberdade (pena de prisão) para o
controle do crime. A própria medida de segurança que deveria distinguir-se da
pena, outra coisa não tem sido, na prática brasileira, senão privação da liberdade,

${ }^{184}$ BACIGALUPO, Enrique. A personalidade e a culpabilidade na medida da pena, p. 35.

${ }^{185}$ Segundo Roberto Lyra, "O Código, no art. 42, acolheu, em essência, os índices da periculosidade de Ferri ("motivos, antecedentes e personalidade do agente"); motivos e fato criminoso ("circunstâncias e consequências do crime)”. Comentários ao Código Penal, p. 208. 
com todos os aspectos de pena indeterminada e, em alguns casos, de arremedo de prisão perpétua. Essa deturpação, que também se verificou na aplicação de outros institutos, revelou, logo cedo, aos nossos olhos, que a bondade de sua lei está mais na sua eficácia do que nas soluções mais avançadas e pouco factíveis, diante de uma certa realidade socioeconômica” ${ }^{186}$.

A crítica de Assis Toledo versa, exatamente, a respeito da falta de estrutura do país para a construção dos estabelecimentos penais necessários para a implementação das medidas de segurança previstas no novo código (penitenciárias, colônias, casas de custódia e tratamento, institutos de trabalho, reeducação, ensino, cadeias públicas, etc.) e todo o corpo especializado necessário para viabilizar as novas teorias codificadas ${ }^{187}$.

Diante do fracasso estrutural brasileiro para esta finalidade, concluiu Assis Toledo:

\begin{abstract}
“Restou do Código de 1940 apenas o seu lado repressivo, como instrumento de rotulagem e marginalização de grande massa de indivíduos, condenados a penas quase sempre não executadas, mas suficientemente poderosas para colocá-los, como foragidos, na clandestinidade, onde sobreviver significa, em regra, praticar novos delitos ou, no mínimo, passar do rol dos malditos e explorados que, para não serem presos, têm que submeter-se a toda ordem de achaques e humilhações” ${ }^{188}$.
\end{abstract}

\title{
2.2.5. Código Penal de 1969
}

O Governo Jânio Quadros confiou a Nelson Hungria a tarefa de elaborar o anteprojeto de Código Penal, apresentado ao governo e publicado pelo Decreto 1.490, de 08 de dezembro de 1962.

Em 1964, o Ministro Milton Campos designou uma comissão revisora, composta pelo próprio autor do anteprojeto e pelos penalistas Roberto Lyra e Helio Tornaghi. Em 09 de fevereiro de 1965, o próprio Ministro dissolveu essa comissão e designou outra,

186 Op. cit., p. 64.

187 Anota, ainda, Assis Toledo que esse contexto de falência do sistema prisional brasileiro, de superpopulação carcerária e de transformação do cumprimento da pena em fator criminógeno levou o próprio Nelson Hungria a aceitar a incumbência de elaborar um anteprojeto de Código Penal.

${ }^{188}$ PIERANGELI, José Henrique. Op. cit., p. 81. 
formada por Nelson Hungria, Hélio Tornaghi e Heleno Fragoso, sob a presidência de Anibal Bruno. Posteriormente, o anteprojeto foi submetido à nova revisão, agora por nova comissão, formada por Heleno Fragoso, Benjamim de Moraes Filho e Ivo D’aquino, cuja missão era, inclusive, uniformizar os textos dos projetos de Código Penal e de Processo Penal $^{189}$.

O texto original do Projeto, publicado em 1963, assumia como finalidade da pena a ação educacional e a recuperação social do criminoso (art. 35).

As medidas de segurança, previstas no Projeto, possuíam as mesmas finalidades, contudo, sua manutenção como sanção distinta da pena só se justificaria num caso: quando o condenado necessitasse de especial tratamento curativo.

A periculosidade aparecia no Projeto como condição para o cumprimento da pena em regime de semiliberdade. $\mathrm{O}$ art. 37 do Projeto dispunha que a possibilidade de cumprimento da pena de reclusão ou de detenção sob o regime de semiliberdade ficaria condicionada à primariedade do acusado e desde que apresentasse "nenhuma ou escassa periculosidade”.

Já segundo a redação final do Código Penal de 1969, a disposição do artigo 52 determinava que a periculosidade do agente deveria ser declarada na sentença, segundo critérios previamente estabelecidos na lei:

Art. $52(\ldots)$

$\S 1^{\circ} \mathrm{O}$ juiz, na sentença, declarará o grau de periculosidade do condenando, classificando-a de:

I - acentuada, quando:

a) O exame dos elementos e circunstâncias referidos neste artigo indicar que o agente tem inclinação para o crime;

b) tratar-se de criminoso por tendência (art. 64, §3º)

II - escassa, quando o exame dos elementos e circunstâncias referidos neste artigo evidenciar a probabilidade de rápida regeneração do agente, desde que submetido a medida reeducativa.

${ }^{189}$ Idem, ibidem, p. 81-82. 
III - nenhuma, quando o exame dos mesmos elementos e circunstâncias evidenciar a desnecessidade do emprego de medidas reeducativas.

Contrariando seu próprio posicionamento anterior, Nelson Hungria trouxe para o seu anteprojeto a classificação dos criminosos (art. 60), fazendo expressa menção à influência do Código Penal italiano (arts. 102, 103 e 108) e os Códigos iugoslavo e grego, além do anteprojeto argentino (arts. 89 e 90).

Art. 60 - Em se tratando de criminoso habitual ou por tendência, a pena, ou soma de penas, pode ser aumentada até o dobro, salvo o disposto no art. 58.

$\S 1^{\circ}$ Considera-se criminoso habitual aquele que:

a) Reincide pela segunda vez na prática de crime doloso da mesma natureza, punível com pena privativa de liberdade;

b) Embora sem condenação anterior, comete sucessivamente, em período de tempo não superior a cinco anos quatro ou mais crimes da mesma natureza, puníveis com pena privativa de liberdade e demonstra, pelas suas condições de vida e pelas circunstâncias dos fatos apreciados em conjunto, acentuada inclinação para tais crimes.

$\S 2^{\circ}$ Considera-se criminoso por tendência aquele que comete homicídio, tentativa de homicídio ou lesão corporal grave, e pelos motivos determinantes e meios ou modo de execução, revela extraordinária torpeza, perversão ou malvadez.

$\S 3^{\circ}$ Fica ressalvado, em qualquer caso o disposto no art. 89.

Ainda que a classificação contida no Código Penal de 1969 de Hungria fosse relativamente moderada (inclusive, foi criticado por esta característica ${ }^{190}$ ) e orientada não apenas em critérios subjetivos, mas também, em elementos de ordem objetiva, é notável, de qualquer forma, a mudança de posicionamento de Nelson Hungria nesse tema.

\footnotetext{
190 Theodolindo Castiglione aplaudiu a classificação de criminosos consagrada no anteprojeto de 1963, criticando-a, no entanto, por considerá-la ainda insuficiente. Para ele, a solução dada pelo anteprojeto de Hungria não atendia suficientemente às necessidades da sociedade frente à periculosidade apresentada por tais espécies de criminosos. Recomendava que a segregação fosse prolongada, enquanto durasse a “periculosidade” desses criminosos e, mencionando os trabalhos do XII Congresso Penal e Penitenciário de Haia, de 1950, que a declaração do hábito criminoso tivesse o parecer de expertos: "O Estado não pode ficar manietado no tratamento de tais infratores: a sua ação, para recuperá-los, deve ser ampla - moral, pedagógica, social, médica - na persistente tentativa de corrigir e curar. De outro lado, não consulta os interesses coletivos a soltura de delinquentes perigosos, enquanto durar a periculosidade. O tratamento dos criminosos habituais e por tendência deve ser unitário, um todo harmônico com o mesmo objetivo de corrigir, regenerar, curar, reintegrar, em suma, o infrator no ritmo normal da vida coletiva”. Criminosos habituais e por tendência perante o Anteprojeto de Código Penal, de Nelson Hungria, p. 148.
} 
Em 1958, em Conferência realizada em Bauru, São Paulo, ainda sob a vigência do Código de 1940, Hungria declarou-se opositor de uma pretensão de classificação de criminosos. Aliás, o Projeto Alcântara Machado, que previa a classificação de criminosos de ocasião e por tendência, foi revisto pela comissão da qual Nelson Hungria integrou e na qual teve contundente participação, sendo modificado, nesse tema, para excluí-la, dando lugar apenas às categorias de criminosos reincidentes genéricos ou específicos.

Naquela oportunidade, Hungria defendera que a personalidade do delinquente deveria ser entendida como dinâmica, impossível, portanto, de ser classificada aprioristicamente pela letra fria da lei:

\footnotetext{
"Cada delinquente tem a sua psicologia, a sua própria intimidade psíquica, o seu modo de ser em face do mundo objetivo, e somente pode ser considerado e tratado como um 'caso' individuado.

(...) A antiga criminologia de classificação ou de tipologia cedeu o passo, na atualidade, à criminologia de casuística”, ${ }^{291}$.
}

As críticas de Hungria a respeito da classificação de criminosos no Projeto Alcântara Machado, aparentemente, foram esquecidas posteriormente, quando da elaboração de seu Projeto:

\begin{abstract}
"O Projeto Alcântara Machado dividia os delinquentes em quatro categorias: ocasionais, por tendência, reincidentes e habituais. Ora, para a identificação dos ‘tipos’ das duas primeiras categorias, não há seguros critérios objetivos. Não existem características constantes ou indícios infalíveis para diferenciar entre criminosos ou que o sejam per accidens e os que o sejam por tendência. Quanto aos criminosos por tendência, nem mesmo se pode asseverar, incontestavelmente, que existam, isto é, não se pode afirmar que haja uma inclinação especial ou fatalística para o crime; mas, ainda eu se pudesse admitir isso não seria lógico que um Código Penal fundamentalmente informado na liberdade volitiva incluísse entre os inimputáveis o delinquente que o é por irresistível tendência. Quanto aos criminosos habituais, não há razão para destaca-los da família dos reincidentes, uma vez que a esses seja aplicado, como
\end{abstract}

${ }^{191}$ Comentários ao Código Penal. Apêndice. Sobre a qualificação dos criminosos. Conferência realizada em Bauru, em 09 de maio de 1958, p. 397. 
no sistema do projeto, um tratamento especialmente rigoroso (acrescente-se: precavido)" ${ }^{192}$.

Mas não apenas Hungria curvou-se à classificação de criminosos, contrariando seu posicionamento de poucos anos antes, mas previu, para os chamados criminosos habituais ou por tendência, nos termos da redação final do Código Penal de 1969, consequências muito mais severas do que as previstas no seu anteprojeto de 1963 e no próprio Código Penal que em vigor à época: a odiosa pena por tempo indeterminado.

Além disso, abandonando os critérios objetivos antes previstos no anteprojeto, a redação final do Código de 1969 trazia a periculosidade, os motivos determinantes, a torpeza e a malvadeza do réu como critérios de aferição da tendência à delinquência ${ }^{193}$ :

Art. 64 - Tratando-se de criminoso habitual ou por tendência, a pena ser imposta será por tempo indeterminado. O juiz fixará a pena correspondente ao crime cometido, que constituirá a duração mínima da pena privativa de liberdade, não podendo ser inferior à metade da soma do mínimo com o máximo cominados.

(...) $\S 2^{\circ}$ Considera-se criminoso habitual quem:

a) reincide pela segunda vez na prática de crime doloso da mesma natureza, em período de tempo não superior a cinco anos, descontado o que se refere a cumprimento de pena;

b) embora sem condenação anterior, comete sucessivamente, em período de tempo não superior a cinco anos, quatro ou mais crimes da mesma natureza e demonstra, pelas suas condições de vida e pelas circunstâncias dos fatos apreciados em conjunto, acentuada inclinação para o crime.

$\S 3^{\circ}$ Considera-se criminoso por tendência quem, pela sua periculosidade, motivos determinantes e meios ou modo de execução do crime, revela extraordinária torpeza ou malvadez.

Caminhava a legislação penal brasileira para a adoção da periculosidade (um dos critérios mais arbitrários herdados da Escola Positivista) como medida da resposta penal. Presente a periculosidade, ou, em outros termos, sendo positivo o juízo de periculosidade,

${ }^{192}$ Idem, ibidem, loc. cit..

${ }^{193}$ Importa anotar que o próprio Nelson Hungria participou de duas das comissões revisoras de seu Projeto de 1963, sendo que a última delas foi presidida por Anibal Bruno, grande defensor da teoria da perigosidade. 
a consequência prática era semelhante à que se via presente no então vigente Código Penal de 1940 com relação às medidas de segurança - o encarceramento por tempo indeterminado - porém, sob o viés retributivo, e não mais preventivo.

A vigência do Código Penal de 1969, convertido em lei pelo Decreto-Lei no 1.004, de 21 de outubro de 1969, foi adiada inúmeras vezes, até que, durante o Governo Geisel, optou-se pela reforma parcial do Código de 1940 e pela revogação definitiva do Código Penal de 1969, por meio das leis $n^{\circ} 6.416 / 77$ e $6.578 / 78^{194}$.

\subsubsection{A Lei ${ }^{0}$ 6.416/1977}

Em razão dos sucessivos adiamentos da vigência do Código Penal de 1969, este acabou sendo ab-rogado. Em 22 de janeiro de 1977, Armando Falcão, então Ministro da Justiça, remeteu ao Congresso Nacional um projeto de lei que alterava substancialmente o Código Penal, além de prever alterações para o Código Processual Penal e as Leis das Contravenções Penais ${ }^{195}$.

As alterações trazidas pela Lei $n^{0} 6.416 / 77^{196}$ não eliminaram o então vigente sistema do duplo binário. Ainda pior, trouxeram como critério de aplicação da pena a

\footnotetext{
194 Anota Francisco de Assis Toledo que as leis acima referidas serviram de providência urgente e de transição: "se, de um lado, amenizaram o problema da superlotação dos estabelecimentos prisionais, de outro, não poderiam ser tidas como solução definitiva para tal problema e menos ainda considerar-se reforma penal verdadeiramente significativa e profunda. Essa reforma seria, com efeito, encetada em outro Governo, com o Ministro da Justiça Ibrahim Abi-Ackel, conhecedor dos problemas que nos afligem no âmbito da administração da Justiça Criminal, por ter sido Relator, na Câmara dos Deputados, da CPI do Sistema Penitenciário (1976) e do Projeto que se transformou na Lei n. 6.416/77”. Op. cit., p. 66.

${ }^{195}$ Alguns precedentes à edição da Lei $n^{\circ}$ 6.416/77 merecem destaque. Como resultado do Seminário de Direito Penal e Criminologia, realizado em Goiânia (GO), em 1973, elaborou-se a chamada Moção de Goiânia. Esse documento preconizou a necessidade de considerar o Direito Penal como disciplina de defesa social e da recuperação do delinquente, objetivando a prevenção de novos delitos. Em fevereiro de 1975, realizou-se em São Paulo o V Congresso Nacional de Direito Penal e Ciências Afins, que tratou, dentre outros temas, da periculosidade, sua aferição e consequências penais. As conclusões do encontro, no que concerne às penas, se orientaram no sentido da aplicação da pena por tempo indeterminado, quanto ao mínimo, para os criminosos habituais e por tendência. Além disso, reforçou a ideia de que a prisão deve restringir-se aos delinquentes que representam um perigo social. Cf. REALE JÚNIOR, Miguel ... [et al]. Penas e medidas de segurança no Novo Código.

${ }^{196}$ Lei $n^{\circ}$ 6.416/77 - Altera dispositivos do Código Penal (Decreto-lei no 2848, de 7 de dezembro de 1940), do Código de Processo Penal (Decreto-lei $n^{\circ}$ 3.689, de 3 de outubro de 1941), da Lei de Contravenções Penais (Decreto-lei no 3.688, de 3 de outubro de 1941) e dá outras providências.
} 
periculosidade do agente. Esta, a exemplo do Projeto Nelson Hungria, era considerada o centro do sistema de penas.

Assim, na contramão do pilar do Direito Penal do fato, a Lei $n^{\circ}$ 6.416/77 preconizava a realização de estudos de prognose criminal sobre pessoas delinquentes para aferição de sua periculosidade ${ }^{197}$. Mesmo tratando-se de um critério fluido e arbitrário, a periculosidade passou a ser critério de aplicação da pena.

Assim dispunha a Lei $n^{\circ}$ 6.416/77, alterando o teor do art. 77, do Código Penal de 1940:

Art. 77 - Quando a periculosidade não é presumida por lei, deve ser reconhecido perigoso o agente:

I- se seus antecedentes e personalidade, os motivos determinantes e as circunstâncias do fato, os meios empregados e os modos de execução, a intensidade do dolo ou o grau da culpa, autorizam a suposição de que venha ou torne a delinquir;

II - se, na prática do fato, revela torpeza, perversão, malvadez, cupidez ou insensibilidade moral.

$\S 1^{\circ}$ Compete ao juiz que presidir a instrução, salvo os casos de promoção, remoção, transferência ou aposentadoria, para os fins do disposto no §5º , do art. 30, declarar na sentença a periculosidade do réu, valendo-se, para tanto dos elementos de convicção constantes dos autos e podendo determinar diligências. $\S 2^{\circ} \mathrm{O}$ juízo poderá dispor, na forma da lei local, de funcionários para investigar, coletar dados e informações com o fim de instruir o requerimento de verificação de periculosidade.

Fica claro do que até aqui se demonstrou que a legislação penal brasileira, até quase a década de 80, ainda via-se ancorada às já superadas ideias defensistas e aos conceitos positivistas como o de perigosidade — ressalte-se, de quase 100 anos antes—, o que acarretava, na prática, em um desmedido arbítrio, resultando, não raramente, num rigor repressivo e num aumento progressivo do índice de encarceramento.

197 A ideia de exame de personalidade para aplicação da pena já era largamente difundida entre muitos penalistas, sob a vigência do Código de 1940. Personalidade e periculosidade, com a Lei n ${ }^{\circ}$ 6.416/77 fundemse e confundem-se em um só conceito. A personalidade, com o avento da Lei ${ }^{\circ}$ 6.416/77, passa de critério para orientar a aplicação da pena a indicativo de periculosidade do agente, o que parece justificar a previsão de investigação do grau de periculosidade antes da prolação da sentença. 
Sem estrutura penitenciária que pudesse comportar o aumento progressivo do número de condenados ao regime carcerário, o Brasil viu-se diante de uma necessidade premente de reforma desse sistema. Não tanto o pensamento jurídico-penal se alterava, mas a realidade impunha uma profunda modificação, por conta da inegável falência estrutural e penitenciária que o país vivenciava.

A periculosidade, nesse contexto, figurava como o grande vilão dessa pretensão de mudança, porquanto permitia o encarceramento baseado num juízo fluido, impreciso e não menos arbitrário, lastreado na "torpeza, perversão, malvadez, cupidez ou insensibilidade moral" do agente.

\subsubsection{A Reforma da Parte Geral de 1984}

Foi com essa missão que o então Ministro da Justiça Ibrahim Abi-Ackel nomeou, em 27 de novembro de 1980, comissão formada pelos juristas Manoel Pedro Pimentel, Francisco de Assis Toledo, Hélio Fonseca, Francisco Serrano Neves, Miguel Reale Junior, René Ariel Dotti, Ricardo Antunes Andreucci e Rogério Lauria Tucci para a elaboração de reforma da Parte Geral do Código Penal.

Apresentado o Anteprojeto ao Ministério da Justiça, foi publicado para receber críticas e sugestões. Foram realizadas revisões por comissões também nomeadas pelo Ministro da Justiça e, finalmente, foram os trabalhos remetidos ao então Presidente João Batista Figueiredo, vindo a ser publicada a Lei $n^{0}$ 7.209, em 11 de julho de 1984 e entrar em vigor em 13 de janeiro de 1985.

Pierangeli traz o pensamento que orientou a reforma da Parte Geral do Código Penal, extraído das palavras do próprio presidente da Comissão que a realizou. A respeito da aplicação da pena, verifica-se a substancial modificação de seu sentido e finalidade, como ideia da comissão de Reforma: 
“Nos projetos de reforma (agora transformados em lei) a pena criminal adquire, pois, para o direito brasileiro, um novo sentido, ao qual estará indissoluvelmente ligada a mencionada exigência de 'necessidade de pena', com as significativas consequências daí decorrentes. Mas não é só. Adotou-se, igualmente, sem restrições e as reservas do passado, o princípio da culpabilidade. Assim, com a reforma em exame, não se admitirá a aplicação de pena sem que se verifique a culpabilidade do agente por fato doloso ou pelo menos por fato culposo. E dessa tomada de decisão extraíram-se as devidas consequências: aboliu-se a medida de segurança para o imputável (...)

Com isso, conforme tivemos oportunidade de afirmar, adotou-se um direito penal do fato-agente que não descura o agente-fato, num esforço de compatibilização, nos limites do possível, entre as teorias da culpabilidade pela condução de vida e da culpabilidade pelo fato singular, dando-se, não obstante, nítida prevalência à segunda corrente, ou seja, àquela que se traduz em um direito penal do fato" ${ }^{198}$.

O subjetivismo que ancorava o arbitrário e superado sistema repressivo brasileiro, agora dava lugar a um Direito Penal do fato, fundado no princípio da culpabilidade. A periculosidade, como prognóstico de delinquência voltado para o futuro, estava explicitamente abolida da disposição a respeito da fixação da pena, na Parte Geral do Código Penal ${ }^{199}$.

Eis o ponto efetivo da mudança de enfoque, com relação ao Código anterior:

\begin{abstract}
“Na culpabilidade pelo fato é o fato que dará os concretos e definitivos limites para a atuação do Estado na esfera penal. Franz Von Liszt percebeu bem isso quando afirmava que, em sua opinião, por paradoxal que pudesse parecer, 'o Código Penal é a Magna Carta do delinquente, protegendo não a coletividade, mas o indivíduo que contra ela se rebela, ao garantir-lhe o direito de ser castigado só quando ocorrerem os pressupostos legais e dentro dos limites legais.
\end{abstract}

\footnotetext{
${ }^{198}$ Op. cit., p. 87.

${ }^{199}$ Membro da Comissão elaboradora da Reforma da Parte Geral do Código Penal, de 1984, Miguel Reale Junior esclarece que seus integrantes "tinham firmada conviç̧ão de que o Direito Penal fincava alicerces na ideia da Culpa em sentido lato, ou seja, a nulla pena sine culpa. Assim, fosse o fim da pena retributivo ou de prevenção geral, positiva ou negativa, a culpabilidade deveria ser a razão de atribuição da ação típica reprovável ao agente, fundado o juízo de censura na análise das circunstâncias do fato ocorrido e jamais se tendo em vista as possíveis atitudes delituosas futuras. Por esses motivos, eliminou-se da Nova Parte Geral a referência à periculosidade, elegendo-se a culpabilidade como dado revelador do merecimento da pena, a ser individualizada a partir da reprovação, a conduta social e a personalidade do agente (...)”. Tentativa de eliminação do critério de periculosidade...
} 
Ora, esses pressupostos e limites muito pouco valeriam se estivessem referidos a conceitos variáveis, pouco seguros, e não a características objetivas que só podem ser oferecidas pelo fato. Daí a já mencionada tipologia de fatos e não de autores" $^{200}$.

Era da essência da reforma a adoção de um Direito Penal que tivesse como base a culpabilidade pelo fato praticado, erigindo-a ao posto de coluna de sustentação de um sistema de índole democrática. E a redação do art. 59 do Código Penal não poderia deixar de evidenciar essa escolha do legislador, destacando a culpabilidade "como critério básico e principal na aplicação da pena” ${ }^{201}$.

No que se refere às medidas de segurança, diante dos resultados que demonstraram sua inutilidade na prática, foram finalmente excluídas para os imputáveis, mantidas exclusivamente para inimputáveis e semi-imputáveis, com o que a pena absorveu as funções de prevenção e assistência, antes atribuídas às medidas de segurança.

Ocorre que a manutenção da personalidade do agente como um dos critérios para a aplicação da pena não dissolveu a marca de subjetividade que tanto caracterizou o estatuto repressivo anterior. A manutenção dessa circunstância judicial, ao contrário, permitiu que as ideias fixadas no pensamento jurídico-penal daquela época em nada se alterassem ao longo do tempo, a despeito do papel que a culpabilidade assumiu perante a função judiciária de individualização da pena ${ }^{202}$.

A personalidade do agente como critério de fixação da pena ainda em vigor faz perdurar aquele juízo fluído e impreciso, sobretudo porque autoriza o juiz a aumentar, a seu próprio critério, a pena-base aplicável com fundamento em um elemento que, conforme se verá mais adiante, sequer tem condições de auferir.

A prática judiciária, mesmo depois da mudança do enfoque por ocasião da reforma da Parte Geral do Código Penal, manteve o juízo subjetivo a respeito da índole do acusado,

\footnotetext{
${ }^{200}$ PIERANGELI, José Henrique. Ibidem, p.87.

201 JÚNIOR, Miguel Reale. Instituições de Direito Penal, p. 406.

202 O posicionamento da doutrina jurídico-penal no tema de aplicação da pena, sob a vigência do Código Penal de 1940 e da Reforma de 1984 será analisado no Capítulo III.
} 
mantendo aberto o campo para um aumento da reprimenda fundada, não raras vezes, exclusivamente no mau comportamento, na malvadeza, na má índole, na perversidade ou na conduta de vida do réu ${ }^{203}$.

Em outros termos, a ideia já difundida de que a personalidade é o centro da aplicação da pena pouco se alterou, porquanto mantida a referência à análise da intimidade do acusado para fixação da pena.

\subsubsection{O Projeto de Lei $\mathbf{n}^{0} 3.473 / 00$}

O Projeto de Lei elaborado por comissão sob a presidência de Miguel Reale Júnior, por determinação do então Presidente Fernando Henrique Cardoso, propõe a extinção da personalidade do agente dentre as circunstâncias de caráter subjetivo, da disposição do Código a respeito da fixação da pena.

O enunciado do Projeto é expresso em afirmar a impossibilidade de aferição da personalidade do acusado, considerando-a de “improvável aferição”:

\footnotetext{
“Mantém-se o capítulo referente à cominação das penas. O projeto, porém, inova o art. 59, ao alargar as possibilidades de individualização judicial da pena. Das três ordens gerais de fatores sobre as quais repousa a individualização da pena, o projeto mantém as que dizem respeito ao fato e à vítima. Quanto ao agente, ao lado da culpabilidade (mesmo considerando o seu sentido mais abrangente, trazido pela Reforma de 1984) e dos antecedentes, determina que a reincidência deixe de ser considerada circunstância agravante obrigatória e que, nos critérios
}

\footnotetext{
203 É bastante atual a obra de Guilherme de Souza Nucci, jurista de reconhecido sucesso no meio universitário, formador de opinião entre alunos dos cursos de Direito e magistrado atuante na Justiça Criminal. Em obra intitulada Individualização da pena, defende o agravamento da pena em razão do modo de ser e dos sentimentos negativos do réu, tais como "agressividade, preguiça, frieza emocional, insensibilidade acentuada, emotividade desequilibrada, passionalidade exacerbada, maldade, irresponsabilidade no cumprimento das obrigações, distração, inquietude, esnobismo, ambição desenfreada, insinceridade, covardia, desonestidade, imaturidade, impaciência, individualismo, xenofobia, racismo, homofobia, perversidade", que se revelam na prática delitiva. Para ele, "o importante, para a verificação da agressividade destrutiva é detectar se o agente do crime sente-se gratificado por vivenciá-la, impingindo o mal a outrem, especialmente quando essa gratificação o leva ao encorajamento de persistir nessa trilha. Este não é um modo de ser aceitável, componente de uma livre opção de estrutura de caráter, merecendo ser coibida e mais severamente apenada a conduta criminosa”. NUCCI, Guilherme de Souza. Individualização da pena, p. 189.
} 
relativos ao autor, a personalidade, considerada de improvável aferição, e a conduta social, devem ceder lugar às condições pessoais e oportunidades sociais a ele oferecidas. No mais, permanece sem alteração o dispositivo”.

Na redação proposta pelo Projeto de Lei n 3.473/00, o atual art. 59, do Código Penal passaria à seguinte redação:

\author{
Individualização judicial da pena \\ Art. 59. O juiz, atendendo à culpabilidade, antecedentes, reincidência e \\ condições pessoais do acusado ${ }^{204}$, bem como as oportunidades sociais a ele \\ oferecidas, aos motivos, circunstâncias e consequências do crime e ao \\ comportamento da vítima, estabelecerá conforme seja necessário e suficiente à \\ individualização da pena: \\ I - a espécie e a quantidade de pena aplicável; \\ II - o regime fechado ou semi-aberto como etapa inicial de cumprimento da \\ pena; \\ III - a restrição de direito cabível. Parágrafo único. A escolha do regime inicial \\ de cumprimento de pena independe da quantidade fixada, observados os limites \\ máximos previstos no art. 34.
}

Enquanto não aprovada a proposta em andamento, a produção doutrinária e a prática jurisprudencial permanecem imbuídas das mesmas ideias de cunho subjetivista, o que demonstra que o sopro do finalismo, sentido em alguns pontos do Código Penal em vigor, não teve força para superar a tradição positivista de outrora ${ }^{205}$.

\title{
2.2.9. O Projeto de Lei $n^{0}$ 236/12
}

\footnotetext{
${ }^{204}$ A expressão “condições pessoais” também é encontrada no Código Penal português (art. 71, §2º “ $d$ ”), no

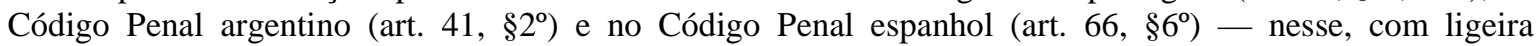
alteração (“circunstâncias pessoais”). Em todos os casos acima, a expressão é empregada como elemento a ser considerado na mensuração da pena pelo juiz ou Tribunal.

${ }^{205}$ A substituição da expressão “personalidade do agente” por “condições pessoais”, no entanto, não está isenta de riscos. Isso, sobretudo, em razão da presença dessa mesma expressão na Lei de Execuções Penais que a traz, em seu artigo 175, para estabelecer os critérios de verificação de cessação da periculosidade: “Art. 175 - A cessação da periculosidade será averiguada no fim do prazo mínimo de duração da medida de segurança, pelo exame das condições pessoais do agente, observando-se o seguinte (...)”.
} 
Em agosto de 2011, o Senador Pedro Taques requereu a criação de Comissão para elaboração de Anteprojeto de Código Penal. Em apenas sete meses de trabalho, a Comissão ${ }^{206}$ apresentou o relatório final do projeto para ser submetido a emendas.

O relatório final apresentado pela Comissão, a exemplo da já mencionada proposta elaborada pela Comissão presidida por Miguel Reale Junior (PL 3.473/00), também retira a circunstância "personalidade do agente” do rol de circunstâncias ${ }^{207}$. Segundo o relatório final apresentado pela Comissão, o critério da personalidade foi retirado do rol de circunstâncias judiciais em razão da necessidade de objetivação das circunstâncias judiciais e da dificuldade de sua aferição por parte dos juízes ${ }^{208}$ :

A objetivação das circunstâncias judiciais.

A proposta retira do espaço de cognição judicial, para fins de dosimetria da pena, aspectos subjetivos como a conduta social e a personalidade do agente. A conduta social porque permitia valorações de cunho moral ou de classe ou estamento social. Já a personalidade do agente se apresentava como de dificílima aferição pelo julgador, pois o processo crime raramente traz tais indicativos psicológicos que permitissem um exame acurado. A retirada destes elementos de grande subjetividade condiz, além de tudo, com o Direito Penal do fato, e não do autor. A proposta é prestigiar as circunstâncias do fato criminoso e a conduta do agente, como grandes elementos para o encontro da pena individual. Daí a menção aos fins, meios, modo de execução e consequências do crime. Isto há de permitir ao julgador exame apropriado da gravidade do fato e da culpabilidade do agente, evitando majorações ou diminuições com base na personalidade ou vida social daquele.

\footnotetext{
${ }^{206}$ Inicialmente formada por Maria Thereza Moura, Antônio Nabor Areias Bulhões, Marcelo Leal Lima Oliveira, Emanuel Messias Oliveira Cacho, Técio Lins e Silva, René Ariel Dotti, Marcelo Leonardo, Gamil Föppel El Hireche, José Muiños Piñeiro Filho, Tiago Ivo Odon, Juliana Garcia Belloque, Luiz Flávio Gomes, Luiza Nagib Eluf, Luiz Carlos dos Santos Gonçalves Marcelo André de Azevedo, Marco Antônio Marques da Silva, a Comissão foi presidida pelo Ministro Gilson Langaro Dipp. A Ministra Maria Thereza Moura e o advogado René Ariel Dotti pediram afastamento da Comissão, logo após o início dos trabalhos.

${ }^{207}$ Segundo o relatório final do PLS 236/12: "Exclusão da personalidade do agente. A única alteração em relação ao texto do Código Penal vigente foi a supressão da 'personalidade do agente', como circunstância preponderante, pelas mesmas razões que presidem sua retirada do cálculo da pena-base: subjetividade e ausência de elementos de aferição nos autos do processo-crime".

${ }^{208}$ A redação do artigo relativo à fixação da pena-base ficou assim disposta no relatório final da Comissão: "Circunstâncias judiciais. Art. 75. O juiz, atendendo à culpabilidade, aos motivos e fins, aos meios e modo de execução, às circunstâncias e consequências do crime, bem como a contribuição da vítima para o fato, estabelecerá, conforme seja necessário e suficiente para reprovação e prevenção do crime (...)”.
} 
A proposta da Comissão de objetivar as circunstâncias judiciais por conta do alto grau de subjetividade contidos nos critérios da "personalidade do agente” e a “conduta social”, a nosso ver, é louvável, porém não está isenta de críticas.

Em primeiro lugar, contrariando o próprio objetivo proposto, a Comissão manteve os critérios “motivos e fins" no referido rol — o que, de acordo com a prática jurisprudencial, representa mais uma porta aberta à análise da subjetividade do agente e a elementos de ordem moral aferíveis por meio da conduta praticada.

Em segundo lugar, a ausência de uma expressão mais restrita no rol de circunstâncias que faça referência ao autor do fato afasta nossa legislação penal da finalidade de individualização da pena, tão almejada e já consolidada por nosso ordenamento jurídico.

O termo utilizado no Projeto de Lei $\mathrm{n}^{\circ}$ 3.473/00 (“condições pessoais do acusado”) ainda nos parece o mais adequado, uma vez que, além de restringir a expressão “personalidade”, evitando um exacerbado grau de subjetivismo a que a jurisprudência frequentemente recorre, permite, de outro lado, considerar aspectos relacionados ao agente que possam indicar ao julgador qual a pena mais adequada do ponto de vista preventivo especial positivo da pena.

\subsection{Primeiras conclusões}

A partir do discurso criminológico, elaborado no contexto das ciências naturais e experimentais, e sob a influência da Psiquiatria como ciência médica, o discurso penal inicia um processo de subjetivação profunda, que se fez sentir na legislação penal produzida a partir do início do século XX.

O positivismo-naturalista, embora nunca tenha sido friamente adotado na legislação penal brasileira, produziu um discurso subjetivista peculiar. Criou uma forma de enxergar o crime e o criminoso e de aplicar a pena que colocou no centro de gravitação da justiça penal a personalidade do delinquente. 
É possível enxergar a influência da Criminologia Positivista na legislação penal brasileira na exploração do conceito da periculosidade, na adoção da personalidade como principal critério para aplicação da pena, na adoção das medidas de segurança segundo o modelo do duplo binário, nos ensaios de classificação de criminosos e na tutela penal da loucura.

Essa influência na legislação penal brasileira e no pensamento jurídico penal de nosso país, no entanto, não foi livre de confusões, equívocos e posicionamentos parciais. Responsabilidade penal, livre-arbítrio e determinismo confundiram-se e, especialmente no Código Penal de 1940, fundiram-se em institutos inconciliáveis, como a adoção da medida de segurança para imputáveis.

A mesma imprecisão de conceitos se fez sentir no natimorto Código Penal de 1969 que previa uma classificação de criminosos voltada apara a aplicação da pena (e não como classificação criminológica), resultando numa solução impensável para um sistema baseado na responsabilidade penal e no caráter retributivo da pena: a pena indeterminada, baseada na periculosidade do agente normal (imputável).

A consagração da periculosidade como centro de sistema de penas deu-se com a Reforma de 1977. A Lei n 6416/77 preconizava o estudo de prognose de periculosidade com fins de aplicação da pena.

Essas confusões influenciaram os penalistas pátrios das mais diversas maneiras e, apenas com o advento da reforma da parte geral de 1984, o Direito Penal brasileiro viu-se livre de alguns elementos mais rigorosos de caráter subjetivista.

No entanto, a evolução do pensamento jurídico-penal e as mudanças legislativas brasileiras não foram suficientes para fazer desaparecer o discurso subjetivista na ciência penal brasileira. Ainda que a culpabilidade tenha assumido posição como critério de aplicação da pena, a personalidade do agente ainda ocupa lugar na legislação penal e, sobretudo, mantem o mesmo sentido de décadas atrás. Mais do que isso, a própria concepção de culpabilidade, na interpretação de boa parte da doutrina e da jurisprudência, 
mantem um sentido de culpabilidade de autor - em suas distintas vertentes de culpabilidade pela condução de vida, da formação da personalidade, da atitude interior como reflexo da ideia de crime como sintoma de uma personalidade anormal ou desviada.

Buscar as origens dessa circunstância judicial aclara a história do caminho subjetivista que a legislação penal brasileira trilhou, a exemplo de muitos outros países influenciados pelos enunciados da Criminologia Positivista e do movimento de Defesa Social.

Desse caminho trilhado, é possível extrair a afirmação de que a análise da personalidade do agente representou o ideal de individualização da pena que o Direito Penal pretendeu alcançar para dar à resposta criminal um caráter utilitarista e mais próximo da realidade social. O combate à criminalidade e a efetiva defesa social, segundo aquelas Escolas, somente seria possível se o Direito Penal se afastasse de premissas abstratas e ideais de justiça e se aproximasse mais da realidade que envolve o crime e o criminoso.

Ao mesmo tempo, a irrupção do conceito de personalidade significou a consagração da função preventivo-especial da pena, também sob a vertente negativa, de necessidade de tratamento e neutralização do delinquente, com o auxílio do discurso médico-psicológico.

Graças à influência de ramos do conhecimento estranhos ao Direito Penal, especialmente a Antropologia Criminal, a Psiquiatria e a Psicologia, a Política Criminal dos mais diversos países alterou-se em busca desse novo ideal, resultando em produções legislativas que consagraram a adoção de um modelo que pudesse auxiliar na busca das causas da criminalidade com a finalidade de dar a resposta adequada ao fenômeno criminoso, defendendo a sociedade e promovendo o tratamento e a ressocialização do delinquente.

Também é possível concluir que a análise de personalidade esteve sempre mais relacionada a um posicionamento determinista do que com a ideia de livre-arbítrio, em matéria de responsabilidade penal. Segundo a tradição do pensamento das escolas penais que a conceberam, o crime é um sintoma da personalidade do agente. Assim, seu modo de ser, sua índole e seu comportamento constituem um determinismo contra o qual a 
sociedade deve defender-se para proteger o corpo social (prevenção especial negativa) e, ao mesmo tempo, promover o tratamento e recuperação do delinquente (prevenção especial positiva em sua concepção antiquada).

Analisadas as bases teóricas que levaram à irrupção do conceito de personalidade na legislação penal, cumpre analisá-la como critério legal de aplicação da pena, à luz da interpretação dada pela doutrina jurídico-penal e pela jurisprudência, analisando suas acepções e verificando seus possíveis critérios de aplicação, assumindo um posicionamento crítico a respeito de sua viabilidade como critério legal de determinação da medida da pena, com atenção aos princípios e garantias constitucionais da dignidade humana e da liberdade de pensamento ${ }^{209}$.

\footnotetext{
${ }^{209}$ Mariângela Gama de Magalhães Gomes ressalta que a atuação do Direito Penal encontra como limites intransponíveis os direitos e garantias individuais elencados pela Constituição Federal. Dessa forma, " $a$ dignidade da pessoa humana, a liberdade e a igualdade assumem no plano constitucional papel de especial relevo quando se tem por objetivo delimitar a atuação do direito penal". Assim, "a eventual incriminação a partir de características pessoais do sujeito também se opõe ao sentido do pluralismo erigido a fundamento da República Federativa do Brasil”. Periculosidade no Direito Penal Contemporâneo, in: Direito Penal Contemporâneo: questões controvertidas, p. 238 e 244.
} 


\section{INDIVIDUALIZAÇÃO JUDICIAL DA PENA}

\subsection{O perfil do art. 59 do Código Penal ${ }^{210}$}

A Reforma da Parte Geral do Código Penal, ocorrida em 1984, alterou significativamente o antigo artigo 42, estabelecendo com precisão "que se deve ter em vista o que se mostra necessário e suficiente para a reprovação e prevenção do crime” ${ }^{211}$.

Segundo os próprios autores do projeto de Reforma da Parte Geral, ocorrida em 1984, o Código Penal assumiu expressamente a finalidade de retribuição com fins de prevenção, que se estabelece segundo sua necessidade e se limita por sua suficiência "através da qualidade, da quantidade e do regime. Trata-se, com a presente fórmula, de viabilizar o princípio da retribuição proporcionada" ${ }^{212}$.

Não obstante a clareza da dicção do dispositivo legal, o sistema de fixação da penabase estabelecido pelo art. 59 tradicionalmente vem sendo manejado pela jurisprudência nacional de forma irracional, violando o dever de respeito à dignidade humana e de proporcionalidade entre o fato e a pena. Constata-se, da experiência prática, uma absoluta arbitrariedade na escolha e avaliação de elementos que supostamente satisfazem o conceito de determinada circunstância judicial - não raras vezes, sequer relacionados com o próprio fato concreto.

É possível afirmar que a presença de elementos subjetivos relacionados ao autor (como a personalidade, os motivos do crime e antecedentes), em certa medida, contribuiu com essa prática, especialmente em razão do caráter "aberto” de tais critérios que, de qualquer forma, o dispositivo legal se limita a elencar, sem apontar para qual direção cada uma delas deve ser tomada no processo de determinação da pena-base.

\footnotetext{
210 Assim prescreve o artigo 59 do Código Penal em vigor: "O juiz, atendendo à culpabilidade, aos antecedentes, à conduta social, à personalidade do agente, aos motivos, às circunstâncias e consequências do crime, bem como ao comportamento da vítima, estabelecerá, conforme seja necessário e suficiente para a reprovação e prevenção do crime: I - as penas aplicáveis dentre as cominadas; II - a quantidade de pena aplicável, dentro dos limites previstos; III - o regime inicial de cumprimento de pena privativa de liberdade IV - a substituição da pena privativa de liberdade aplicada, por outra espécie de pena, se cabível”.

${ }^{211}$ Cf. REALE JÚNIOR, Miguel ... [et al]. Penas e medidas de segurança no novo código, p. 160.

${ }^{212}$ Idem, ibidem, p. 37.
} 
A título de exemplo, cita-se o seguinte caso (HC 200.228/RJ) levado pela Defensoria Pública, por meio de habeas corpus, ao Superior Tribunal de Justiça, com a finalidade de revisão da fixação da pena-base. O paciente, apenado em 8 anos e 8 meses de reclusão, em regime inicial fechado, pela prática dos crimes dos artigos 14 da Lei $\mathrm{n}^{\circ}$. 10.826/2003 e art. 333 do Código Penal, em concurso material, alegou a desproporcionalidade entre o fato praticado e a pena aplicada, fixada em $75 \%$ acima do mínimo legal, sem fundamentação idônea. Além disso, o magistrado sentenciante teria se valido de elementos do próprio tipo penal e da folha de antecedentes criminais do agente para a exasperação da reprimenda.

A seguir, a ementa do acórdão:

"HABEAS CORPUS. PORTE ILEGAL DE ARMA DE FOGO DE USO PERMITIDO E CORRUPÇÃO ATIVA. DOSIMETRIA. PENA-BASE. CULPABILIDADE. ACENTUADA REPROVABILIDADE DA CONDUTA DELITUOSA PRATICADA. ANTECEDENTES E CONDUTA SOCIAL. FUNDAMENTAÇÃO CONCRETA. PERSONALIDADE VOLTADA À PRÁTICA DE DELITOS. NEGATIVIDADE JUSTIFICADA. EXISTÊNCIA DE DIVERSAS CONDENAÇÕES DEFINITIVAS ANTERIORES. ATENUANTE DA CONFISSÃO ESPONTÂNEA. REINCIDÊNCIA. COMPENSAÇÃO. INTELIGÊNCIA DO ART. $67 \quad$ DO $\quad$ CP. CONSTRANGIMENTO ILEGAL EM PARTE EVIDENCIADO. SANÇÃO REDIMENSIONADA. 1. Não há constrangimento ilegal no ponto em que foi realizado o aumento da pena-base em razão da culpabilidade, haja vista a acentuada reprovabilidade da conduta delituosa praticada pelo paciente, tendo em vista que foram apreendidas com ele duas armas de diferentes calibres, bem como considerável quantidade de munição, e também por ter sido abordado 'circulando em um carro com as mencionadas armas, touca ninja e luva'. 2. Não há como afastar a conclusão acerca dos maus antecedentes, da personalidade voltada para a prática de ilícitos e da má conduta social, quando verificada a existência de cinco condenações definitivas anteriores em desfavor do paciente, uma delas inclusive geradora de reincidência, indicativas de que seu envolvimento com o ilícito não é esporádico, a justificar a exasperação da penabase. 3. Consoante entendimento da Sexta Turma deste Tribunal, a atenuante genérica da confissão espontânea, por envolver a personalidade do agente, também é circunstância preponderante, devendo ser compensada com a agravante da reincidência. Inteligência do art. 67 do Código Penal. 4. Ordem 
parcialmente concedida apenas para proceder à compensação entre a agravante da reincidência e a atenuante da confissão espontânea, tornando a reprimenda do paciente definitiva em 7 anos e 6 meses de reclusão e pagamento de 37 diasmulta. (HC 200228/RJ, Rel. Ministro Sebastião Reis Júnior, Sexta Turma, julgado em 17/11/2011, DJe 14/12/2011, destaques nossos).

A fundamentação da fixação da pena pela sentença de primeira instância foi mantida integralmente pelo Tribunal de Justiça do Rio de Janeiro e assim estabelecia:

\footnotetext{
“Do crime previsto no artigo 14, da Lei 10.826/03

Da pena-base

A reprovabilidade do acusado excedeu a normal do tipo. Com efeito, com os acusados foram apreendidas duas armas de diferentes calibres, bem como considerável quantidade de munição. Além do mais, os réus foram abordados circulando em um carro com as mencionadas armas, touca ninja e luva. Ademais, a análise da extensa folha de antecedentes criminais do acusado indica que o mesmo ostenta diversas anotações criminais (DEZ), contando até o momento com quatro condenações definitivas ( $3^{\mathrm{a}}, 4^{\mathrm{a}}, 7^{\mathrm{a}}$ e $8^{\mathrm{a}}$ anotações). Por óbvio, é o acusado portador de maus antecedentes, com personalidade voltada para a marginalidade e contumaz no mundo do crime, bem como ostenta conduta social inteiramente reprovável. [...]”.
}

A culpabilidade, circunstância judicial prevista no art. 59 do Código Penal, foi tratada pelo magistrado como "reprovabilidade". Como elemento do fato concreto utilizado como critério de aferição, o magistrado elegeu o fato de terem sido apreendidas duas armas de distintos calibres, a grande quantidade de munição e o fato de o paciente trazer, no interior veículo, além das armas e munições, uma touca "ninja” e luva. Como elemento do fato utilizado para aferição da personalidade, da conduta social e antecedentes o magistrado elegeu os mesmos fatos: a quantidade de anotações criminais em folha de antecedentes e as condenações definitivas ostentadas.

Importante destacar que o eg. Superior Tribunal de Justiça, para justificar a manutenção da pena fixada pelas demais instâncias, ressaltou que o magistrado sentenciante considerou quatro circunstâncias desfavoráveis, muito embora todas elas refiram-se ao mesmo elemento do fato concreto: 


\begin{abstract}
"Nesse ponto, também não vejo nenhuma ofensa ao princípio da proporcionalidade, tendo em vista que a pena cominada abstratamente ao delito em questão é de 2 a 12 anos e o juiz sentenciante fixou a pena-base do paciente em 4 anos de reclusão, ou seja, em apenas 2 anos cima do mínimo previsto, mesmo tendo verificado que o acusado ostenta quatro circunstâncias judiciais desfavoráveis”.
\end{abstract}

Fica claro, do exemplo acima descrito a liberdade de que se valeu o magistrado para tomar qualquer elemento como critério de avaliação das circunstâncias judiciais, sem que se houvesse uma necessária vinculação do elemento do fato concreto que se relacione ao injusto, à gravidade da lesão ou do perigo de lesão ao bem jurídico ou, ainda, ao desvalor da ação e do resultado ${ }^{213}$.

A falta de uma linha de orientação doutrinária clara a respeito da forma de concretizar a medida da pena com base nos elementos do fato concreto em correspondência com as circunstâncias elencadas no art. 59 do Código Penal, de outro lado, vem levando a jurisprudência a valorar, segundo seu próprio arbítrio, quais são as circunstâncias que reputa relevantes para a dosimetria da pena, muitas vezes, sem atenção à necessidade de proporcionalidade entre a pena e o fato praticado.

Juarez Tavarez adverte para esse fato, reforçando a necessidade de proporcionalidade, ao considerar que "quando o artigo 59 se refere à reprovação, fá-lo no sentido de exigir que a pena aplicada deva ser proporcional ao dano ou ao perigo do bem jurídico" ${ }^{214}$.

Além disso, o autor vê as circunstâncias do artigo 59, do CP, como circunstâncias de ponderação submetidas ao crivo de necessidade e de proporcionalidade ${ }^{215}$. Por tal razão, afirma, apoiando-se no pensamento de Claus Roxin, que se a pena for desnecessária, para

\footnotetext{
${ }^{213}$ Note-se que a culpabilidade, como juízo de reprovabilidade que se faz contra o autor por não orientar sua conduta conforme a norma, foi avaliada, na hipótese, como sendo o próprio fato incriminado: o porte ilegal de arma de uso permitido. A quantidade de armas e munição também foi tomada como critério de aferição de reprovabilidade. $\mathrm{O}$ fato de o apelante portar uma touca e luvas no interior do veículo - fato que, destaquese, sequer se relaciona com o bem jurídico tutelado pelo crime pelo qual o paciente, no caso, foi condenado - também serviu como critério de aferição da culpabilidade e, por consequência, como fundamento do aumento da pena-base.

${ }_{214}^{214}$ TAVAREZ, Juarez. Culpabilidade e individualização da pena, p.124.

${ }^{215}$ Muito embora a redação do art. 59 fale em necessidade e suficiência.
} 
fins preventivos, não deverá ser imposta e, se as condições do art. 59 forem favoráveis ao réu, a medida da pena deve reduzida para aquém dos limites fixados pela culpabilidade.

A culpabilidade, erigida pelo art. 59 a principal critério de fixação da pena, será o limite máximo que o juiz deve observar para, a partir dele, promover as reduções que as circunstâncias do art. 59 venham a autorizar, pois são, segundo aquele autor, critérios complementares que devem ser considerados em favor do réu, e não contra ele: "Se assim não for estar-se-á criando uma pena dissociada do fato e, ademais, introduzindo-se, na sua medida, fatores morais, que não têm a ver com a reprovabilidade jurídica” ${ }^{216}$.

Também, nesse mesmo sentido, se posiciona Paulo José da Costa Jr, para quem as finalidades da pena apontadas expressamente no artigo 59 do Código Penal deverão ser perseguidas observando-se, acima de tudo, a culpabilidade do agente, não podendo o juiz excedê-la na dosimetria da pena. E, adverte:

\begin{abstract}
“Nada impede, porém, que razões de prevenção especial levem o juiz a fixar uma pena abaixo do limite determinado pela retribuição justa da culpabilidade, evitando-se o efeito dessocializador que a pena privativa de liberdade possa exercer, substituindo-a então por medidas alternativas” ${ }^{217}$.
\end{abstract}

\title{
3.1.1. A subjetividade como característica marcante do modelo brasileiro
}

A Reforma da Parte Geral do Código Penal de 1984, não obstante tenha trazido para o processo de individualização da pena uma profunda transformação ao estabelecer os limites da "necessidade" e "suficiência", bem como ao inserir a culpabilidade dentre as circunstâncias judiciais, não perdeu sua marca tradicional de subjetividade.

A doutrina reconhece a prevalência dos elementos subjetivos, especialmente a personalidade do agente, sobre os demais elementos para a fixação judicial da pena, o que

\footnotetext{
${ }^{216}$ Ibidem, p. 129. Na contramão desse entendimento, a maior parte da jurisprudência consultada utiliza-se das circunstâncias judiciais como elementos de exasperação, e não de diminuição da pena-base.

${ }^{217}$ COSTA JUNIOR, Paulo José da. Código Penal Comentado, p. 198.
} 
colaborou para que, na jurisprudência, os critérios subjetivos tenham se tornado fatores de predileção para o cálculo da pena-base ${ }^{218}$.

A própria orientação do Código Penal é nesse sentido. O art. 67 prescreve expressamente: "No concurso de agravantes e atenuantes, a pena deve aproximar-se do limite indicado pelas circunstâncias preponderantes, entendendo-se como tais as que resultam dos motivos determinantes do crime, da personalidade do agente e da reincidência” ${ }^{219}$.

Os riscos de uma prevalência pelos elementos subjetivos na fixação da pena, sem que estejam fundamentalmente atrelados tão somente à perspectiva da prevenção especial positiva, mas relacionados à culpabilidade, são vários. Sobretudo, residem na permissão de exasperação da pena fundada em elementos não relacionados ao fato e de uma indevida análise de periculosidade, mesmo já tendo sido expressamente abolida do ordenamento jurídico-penal como critério de fixação de pena.

É o que se pode constatar no pensamento de José Frederico Marques que, confundindo a extinta análise de periculosidade com o conceito de personalidade mantido no art. 59 do Código Penal, assevera: "não se pode desprezar a periculosidade como fator de graduação da pena” 220 .

Nota-se, assim, certa persistência na análise da periculosidade do agente, mesmo diante de um novo sistema no qual as medidas de segurança e a aferição da periculosidade

\footnotetext{
${ }^{218}$ Nesse sentido, José Frederico Marques: “As circunstâncias preponderantes, quer judiciais, quer legais, são aquelas que dizem respeito à personalidade do agente. (...) Conclui-se, segundo se vê, que o legislador deu prevalência, na individualização da pena, aos elementos de ordem subjetiva. Os fatores de natureza objetiva, ou elementos resultantes da gravidade do crime ficam em segundo plano". MARQUES, José Frederico. Tratado de Direito Penal, p. 324. No mesmo sentido, Silva Franco: "A enumeração destas circunstâncias indica que o legislador de 84 deu primazia às circunstâncias de conotação subjetiva, em detrimento das de caráter objetivo, numa posição, aliás, coerente com o princípio do direito penal da culpa que informou toda a reformulação da Parte Geral do Código Penal” FRANCO, Alberto Silva. Código Penal e sua interpretação, p. 379. Vale notar, no entanto, que discordamos do referido autor quanto à afirmação de que a prevalência dos elementos subjetivos justifica-se no princípio do Direito Penal da culpa, pois apenas um Direito Penal da culpa pela conduta de vida ou pela formação da personalidade justifica a prevalência da subjetividade, em detrimento dos elementos objetivos relacionados ao fato.

${ }^{219}$ Ainda segundo Frederico Marques: "A personalidade do criminoso, os motivos determinantes do crime, a periculosidade do agente, alguns elementos subjetivos do fato típico, — tudo isso são fatores de graduação da pena ou de aplicabilidade de medidas de segurança, presos ao modo de ser do autor, em que se verifica a existência de indisfarçável conteúdo criminológico". Tratado de Direito Penal, p. 84.

${ }^{220}$ Idem, ibidem, loc. cit..
} 
estão reservadas, tão somente, aos inimputáveis ${ }^{221}$. A “solução” encontrada pelo referido autor é a seguinte:

\begin{abstract}
“Todavia, ante o nosso sistema dualístico de pena e medidas de segurança, hoje unitário, pois a medida de segurança não serve mais a imputáveis, a apreciação da periculosidade deve ser feita, no juízo de culpabilidade sobre a conduta de vida, não só para aumentar a sanção punitiva de privação de liberdade, como ainda para estabelecer, em certos casos, um equilíbrio justo entre a pena a ser aplicada e a medida de segurança que deve ser imposta” ${ }^{222}$.
\end{abstract}

Conforme se verá mais adiante, a vertente da culpabilidade pela formação da personalidade e pela conduta de vida (mesmo em seus matizes mais moderados), como critério de aplicação da pena é o que doutrina penal alemã hoje designa de "concepção antiquada da culpabilidade”. É com o auxílio dessa concepção que encontram espaço no processo de dosimetria da pena os elementos de ordem subjetiva, com prevalência irrestrita sobre os demais, mesmo quando não atrelados ao fim de prevenção especial positiva.

Como já dito anteriormente, a jurisprudência revela essa predileção conduzindo-se numa direção perigosa voltada para o aumento da pena-base com o auxílio predominante do critério da "personalidade do agente", seja como circunstância de aferição do grau de reprovação do autor, seja como circunstância judicial própria.

Também a título de exemplo, observe-se o seguinte julgado de lavra do Tribunal de Justiça de São Paulo (Apelação Criminal 0011354-24.2002.8.26.0011, da 16 ${ }^{\text {a }}$ Câmara Criminal, julgado em 10 de janeiro de 2012). A decisão do Tribunal reforma a sentença condenatória que agravou a pena com fundamento na "personalidade voltada para o crime” baseando-se em crime posterior. Contudo, embora o acórdão discorde da interpretação do

${ }^{221}$ Na jurisprudência recente também se encontram exemplos de dosimetria da pena fundamentada na periculosidade do agente. Nesse sentido, acórdão do Tribunal de Justiça de São Paulo, em julgamento de Revisão Criminal ajuizada com a finalidade de redução da sanção. O Des. Relator fundamentou que a pena aplicada (26 anos e oito meses de reclusão) não merecia redução maior que oito meses, pela prática do crime do art. $157, \S 3^{\circ}$, terceira parte, na forma continuada, em razão da periculosidade do agente (tratada como circunstância judicial de fixação da pena-base). Do voto do relator: “(...) Maior redução, data venia, seria desconsiderar as demais circunstâncias judiciais destacadas, motivadamente, na dosimetria da pena, no entendimento da maioria, muito mais graves que a simples reincidência em face da extremada periculosidade do peticionário, especialmente" (RC 228.676-3, $1^{\circ}$ Grupo de Câmaras Criminais, rel. Andrade Cavalcanti, j. 18.05.98).

${ }^{222}$ Idem, ibidem, loc. cit.. 
magistrado sentenciante, de outro lado, reafirma a ideia de que o subjetivismo conferido pela lei ao magistrado é necessário para a individualização, inclusive para o aumento da pena-base. Eis a ementa do acórdão:

\begin{abstract}
"Homicídio duplamente qualificado tentado. Apelação que alega ser o veredicto frontalmente oposto às provas dos autos. Art. 593, inciso III, alínea d, do CPP. Impossibilidade. Análise da culpabilidade limitada à sustentabilidade da decisão dos juízes leigos face às interpretações probatórias constantes dos autos. Caso em que a decisão dos jurados, valorando livremente as provas produzidas, concluiu pela condenação. Depoimento da vítima confirmado por sua namorada que, confrontado com a negativa do apelante em desencontro com as testemunhas de defesa, possibilita a conclusão dos Juízes leigos. Veredicto em harmonia com as provas dos autos. Fixação da pena que merece reparo. Penabase fixada em patamar acima do mínimo com fulcro na suposta personalidade criminosa do apelante. Personalidade aferida apenas com base em condenação sem comprovação de trânsito em julgado de delito que teria sido praticado após a tentativa de homicídio. Impossibilidade. Apelo parcialmente provido apenas para reduzir a reprimenda a oito anos de reclusão”.
\end{abstract}

O réu, condenado a 9 anos e 4 meses de reclusão — a pena-base foi fixada 1/6 acima do mínimo - a serem cumpridos em regime inicial fechado pela tentativa de homicídio qualificado, ofereceu recurso pleiteando a reforma da sentença, dentre outros motivos, para reduzir a sanção.

Do voto do relator Des. Almeida Toledo, extraem-se os seguintes trechos, fundamentos da reforma:

\footnotetext{
"A dose de subjetivismo conferida pela Lei ao Magistrado na apreciação das circunstâncias judiciais é imprescindível para a individualização da pena, garantida pela Carta da República a todos os cidadãos. Apesar disso, considerar que conduta mais recente possa elevar a pena de delito cometido anteriormente em razão da demonstração de personalidade voltada para o crime é prática que muito se aproxima da ideia de direito penal do inimigo, teorizado por Jakobs (...) Como é possível que o Magistrado entenda que a pena do agente deve ser majorada por ostentar personalidade criminosa depois do delito? A Lei permite que se puna com maior gravidade o criminoso de personalidade deturpada
} 
justamente porque esse a transgressão da lei teria sido facilitada por essa característica. No momento da tentativa de homicídio, LUCAS era primário e ostentava bons antecedentes. Os fatos ocorridos em sua vida após aquele delito só poderão ser analisados em eventuais crimes posteriores. O Tribunal do Júri Popular, em sessão realizada em 14 de janeiro de 2011 (fls. 552/555), julgava o LUCAS de fevereiro de 2002, quando disparou contra a vítima. A personalidade que demonstrou ostentar mais tarde pode não ser a mesma do momento da condenação e provavelmente difere daquela do momento dos fatos”.

Do caso em análise, tiram-se duas conclusões: em primeiro lugar, a sentença de primeira instância demonstra que um crime posterior ao em julgamento foi utilizado como critério para aferição de personalidade e fundamento do aumento da pena, o que afronta o Direito Penal do fato e demonstra o absoluto descaso do julgador com a relação fato/pena.

Em segundo lugar, o acórdão do TJSP demonstra que, mesmo tendo reformado a sentença condenatória com base na mencionada impropriedade da sentença, o Tribunal convalida a ideia de que é legítimo o aumento de pena fundado na análise de personalidade — especialmente porque a personalidade “deturpada” facilita a prática criminosa — o que revela a adoção de um entendimento no sentido de apenar-se o agente pelo que ele é ou pela personalidade que ostenta. Por fim, demonstra que, para o d. Relator, o subjetivismo é o meio “imprescindível” para a individualização da pena, ideia central herdada do Positivismo Criminológico.

Ambas as decisões, a nosso ver, são exemplos do caráter subjetivista da lei penal em matéria de fixação da pena e ferem de modos distintos tanto o princípio da proporcionalidade entre o fato praticado e a pena aplicável, afastando-se, cada qual, de uma orientação da culpabilidade pelo fato.

\subsubsection{A individualização da pena no modelo brasileiro}

O tão almejado fim de individualização da pena, já tratado detalhadamente nos capítulos iniciais, como bem relembra Luiz Regis Prado, foi solidificado por Saleilles como 
“(...) missão a ser desempenhada de modo complementar pelo legislador, pelo juiz e pela administração penitenciária com vistas a um sistema de responsabilidade verdadeira, de responsabilidade concreta, apreciada individualmente, em cada individuo, em cada caso particular, em lugar de uma responsabilidade em bloco, fictícia e abstrata, invocada contra cada um e contra todos em virtude de uma mesma fórmula jurídica” ${ }^{223}$.

No entanto, o objetivo de individualização da pena, alçado a garantia fundamental pela Constituição Federal, na história do nosso ordenamento jurídico, como bem ressalta Regis Prado, acabou dando lugar à defesa de sentenças absoluta ou relativamente indeterminadas, como forma de atendimento às exigências de prevenção especial e, especialmente, como forma de defesa da sociedade ${ }^{224}$.

Não obstante as modificações que a lei penal brasileira sofreu com a Reforma da Parte Geral do Código Penal de 1984, especialmente a abolição do critério da periculosidade e da sentença indeterminada, é inquestionável que o perfil subjetivista do estatuto repressivo colaborou em boa medida para o insucesso do objetivo de individualização judicial da pena. De fato, o que se constata da experiência é exatamente o contrário do fim de individualização.

Lei, doutrina e jurisprudência compartilham, ainda hoje, a visão subjetivista arraigada em nosso sistema penal de fixação judicial da pena. Quanto mais a subjetividade do autor importa para o processo de dosimetria, mais o objetivo de individualização distancia-se da realidade possível, submetendo o agente, na prática, a uma pena arbitrária e dissociada do fato praticado.

Por outro lado, é indiscutível que a atuação intuitiva dos juízes, à mingua de critérios normativos de individualização e graduação das circunstâncias judiciais, leva a um sistema irracional de aplicação da pena, o que impossibilita uma legítima e adequada individualização judicial. Some-se a isso o fato de a aferição dos elementos subjetivos por parte do magistrado, especialmente a respeito do critério "personalidade do agente",

\footnotetext{
${ }^{223}$ PRADO, Luiz Regis. Curso de Direito Penal Brasileiro, p. 627.

${ }^{224}$ Ibidem, loc. cit..
} 
segundo a experiência demonstra, carece de critérios adequados e de um mínimo de segurança jurídica, conforme se verá mais adiante.

\subsection{Teorias sobre a individualização judicial da pena}

\subsubsection{A necessidade de racionalização do processo de determinação judicial da pena}

Tal como nos países europeus que, mais atualmente, avançaram no desenvolvimento de uma teoria da determinação da pena ${ }^{225}$, quase nada se produziu na doutrina nacional em matéria de individualização judicial da pena.

A carência de uma teoria da determinação da pena ou da elaboração teórica de critérios racionais para o processo de fixação da pena pelo juiz levou nossa jurisprudência a um absoluto desconcerto orientado por uma irracionalidade discricionária na avaliação de elementos relacionados ao crime e ao criminoso, e na sua valoração como critérios de relevância para a mensuração da pena final ${ }^{226}$.

Aliado a isso, o modelo subjetivista do Código Penal brasileiro enfatizou a finalidade de prevenção especial negativa e o fim de tratamento do delinquente, desprezando o papel da valoração do injusto, a necessidade da não dessocialização do apenado (prevenção especial positiva em sua concepção mais moderna) e a necessária proporcionalidade entre a pena e o fato praticado como base fundamental do processo de determinação da medida da pena.

\footnotetext{
${ }^{225}$ Merecem destaque a doutrina alemã e a espanhola a respeito do tema.

${ }^{226}$ A mesma deficiência é referida por Bernardo Feijoo Sánchez a respeito do sistema penal espanhol: "Chamam a atenção as escassas contribuições da doutrina espanhola a este debate internacional e a escassa ressonância do mesmo a nível interno. Ainda que seja evidente a importância desta questão em países nos quais os órgãos judiciais gozam de uma ampla margem de decisão com respeito à concretização da pena, inclusive os sistemas que, como o nosso, se caracterizam por uma maior desconfiança do legislador para o órgão jurisdicional à hora de determinar a pena concreta (...)”. Tradução livre. SÁNCHEZ, Bernardo Feijoo. Individualización de la pena y teoría de la pena proporcional al hecho, p. 3.

Também, nesse sentido, a crítica de Bernd Schünemann: "A ciência penal alemã, reconhecida mundialmente por seus resultados na sistematização dos pressupostos de punibilidade, os quais em grande medida foram aceitos, tem descuidado por completo durante décadas do campo da medição da pena, apesar de que para o acusado - em muitos casos - a pergunta acerca da determinação da pena é a decisão judicial mais importante(...)" Tradução livre. In: HÖRNLE, Tatjana. Determinación de la pena y culpabilidad. Prólogo, p. 17.
} 
A tudo isso se deve, como já dito, a desmedida discricionariedade dos juízes na prolação de sentenças criminais, que é exatamente o momento mais importante do processo de persecução penal, sob a perspectiva do acusado.

Nesse âmbito, a crítica de Patricia Ziffer deve ser destacada. Para a autora, é nada menos que desconcertante a enorme preocupação por fixar um sistema dogmático de alta precisão quando se trata de estabelecer o sim ou não da aplicação de uma consequência penal, entre outras razões, para se evitar que o autor fique sujeito ao arbítrio judicial, mas de outro lado, considerar esse mesmo arbítrio como um valor intangível, inerente à natureza da mensuração da pena. Isso é contraditório não apenas se se vê na teoria do delito fundamentalmente uma garantia frente à discricionariedade estatal, senão também, e especialmente, se se admite como a expressão da necessidade de racionalidade das decisões $^{227}$.

\footnotetext{
"Se todos aqueles princípios (legalidade, fato, culpabilidade,) tão zelosamente conservados ao elaborar o esquema da teoria do delito podem ser deixados de lado sem mais nem mais ao graduar a sanção, ficam quando menos parcialmente desqualificados todos os esforços teóricos realizados até ali, dado que tudo aquilo que foi rechaçado incondicionalmente antes poderá agora ingressar na análise sem maiores questionamentos (p.e.: perigosidade do autor, sua conduta durante o processo, etc.) ${ }^{, 228}$.
}

Ainda, para a autora, se se parte da necessidade de que as decisões tenham fundamentos explícitos a respeito dos quais seja possível uma discussão racional como meio de controle dessas decisões, é necessário estabelecer pautas teóricas mais ou menos firmes que guiem o processo de individualização da pena e circunscrever os limites que não é possível ultrapassar ${ }^{229}$.

\footnotetext{
${ }^{227}$ ZIFFER, Patricia S. Consideraciones acerca de la problemática de la individualización de la pena, p. 48. ${ }^{228}$ Tradução livre. Idem, ibidem, loc.cit..

${ }^{229}$ Idem, ibidem, p. 49.
} 
Com essa finalidade, algumas teorias vêm sendo desenvolvidas já há algumas décadas em países europeus, mas que ainda não se reproduziram na produção doutrinária brasileira $^{230}$.

Conforme aponta Demetrio Crespo, o problema da individualização judicial da pena é eleger a pena justa a partir do marco penal típico concretamente determinado, o que supõe não só a fixação da classe e quantidade de pena aplicável ao caso concreto, senão também, eventualmente, a decisão sobre aplicação ou não de substitutivos penais. Em sentido estrito, a individualização judicial da pena é a decisão sobre o tipo e a quantidade da pena que corresponde aplicar ao autor de um fato delitivo pela transgressão culpável de um preceito penal, decisão na qual o primeiro passo lógico é a eleição entre a pena privativa de liberdade e a pena de multa ${ }^{231}$.

$\mathrm{O}$ ato de individualização, afirma aquele autor, tem sido qualificado como um ato de discricionariedade jurídica vinculada. Assim, o juiz pode mover-se livremente a partir do princípio do marco legal previamente estabelecido pelo legislador para determinado crime e àquele corresponde a missão de concretizar a cominação penal da lei para o caso concreto, mas sempre orientado por alguns princípios que haverão de se extrair das declarações expressas em lei, ou dos fins do Direito Penal em seu conjunto ou, ainda, dos fins da pena ${ }^{232}$.

Independentemente dos critérios-guia próprios de cada ordenamento jurídico que servem de orientação para a determinação da medida da pena, o autor afirma que a individualização judicial da pena constitui um momento da intervenção do sistema penal que não pode relegar-se à intuição, senão a um processo determinado de racionalização.

Sem qualquer pretensão de se esgotar o tema das teorias da determinação da pena, cumpre esboçar suas principais elaborações doutrinárias, de forma a contribuir para uma análise mais racional das balizas propostas pelo art. 59 do Código Penal brasileiro e do papel da personalidade como critério subjetivo no processo de fixação judicial da pena,

\footnotetext{
${ }^{230}$ Importante excepcionar a doutrina de Juarez Tavares que tratou o tema com alguma profundidade na obra consultada.

${ }^{231}$ DEMETRIO CRESPO, Eduardo. Notas sobre la dogmática de la individualización de la pena, p. 22.

${ }^{232}$ Idem, ibidem, loc. cit..
} 
propondo-se uma racionalização baseada em critérios possíveis e aferíveis a partir dos elementos fornecidos pelo fato concreto ${ }^{233}$.

\subsubsection{Alguns modelos teóricos do debate europeu}

\subsubsection{Teoria da proporcionalidade pelo fato ou da pena proporcional ao fato}

É pertinente que esta exposição se inicie com a apresentação de um modelo de teoria de determinação da pena que representa uma direta oposição à tendência de enfatizar a prevenção especial, que, por sua vez, ressalta os elementos subjetivos relacionados ao autor do fato.

A teoria da proporcionalidade pelo fato ou da pena proporcional ao fato, de origem anglo-saxã, segundo Feijoo Sánchez, é uma das teorias que mais influência teórica e prática vem exercendo sobre o Direito comparado, produzindo um debate profundo sobre os modelos de determinação da pena em outros países do âmbito continental, como na Alemanha ${ }^{234}$.

A teoria da pena proporcional surgiu, ainda segundo aquele autor, em um contexto de oposição teórica aos “efeitos perniciosos” de uma prática judicial orientada à prevenção especial $^{235}$. O fracasso das práticas ressocializadoras em países escandinavos, como Suécia

${ }^{233}$ Demetrio Crespo faz referência ao posicionamento crítico de Bruckmann. Afirma que o Código Penal alemão é defeituoso e, no que se refere à individualização da pena, é inconstitucional, pois faz alusão a diversas circunstâncias que deverão ser tidas em conta pelo juiz na individualização da pena, mas que supõem um campo demasiado extenso para poder ser abarcado pelo juiz e, de outro lado, não indica nem a medida em que cada uma dessas circunstâncias deve influir na quantidade de pena, nem as relações que devem estabelecer-se entre elas, ao que soma a circunstância de que algumas delas podem jogar tanto em sentido agravatório, como em sentido atenuatório. Por tudo isso, Bruckmann chega à conclusão de que, em definitivo, a lei não regula o direito da individualização da pena posto que dele não resulta uma indicação válida para proceder na prática. Apud DEMETRIO CRESPO, Op. cit., p. 28, destaques nossos.

${ }^{234}$ SÁNCHEZ, Bernardo Feijoo. Individualización de la pena y teoria de la pena proporcional al hecho, p. 5.

${ }^{235}$ O autor anota que a expressão "nothing works" ficou conhecida por meio do americano Robert Martinson, representante do movimento crítico ocorrido nos anos setenta contra o modelo orientado à prevenção especial, dominante naquela época. O mencionado autor publicou o trabalho: What Works - questions and answers about prision reform (1974) e analisou 231 estudos de avaliação de internos de prisões norteamericanas, chegando à conclusão de que "nada funciona" no que se refere à reabilitação pela prisão. O trabalho de Robert Martinson é uma crítica severa à ideologia de tratamento e à visão do crime como uma doença, que nega a normalidade do crime na sociedade. Tais tratamentos, segundo o autor americano, acabam tornando-se tão draconianos que chegam a ofender a ordem moral de uma sociedade democrática. 
e Noruega e, ainda, nos Estados Unidos, deu ensejo ao aparecimento de uma corrente doutrinária com posteriores triunfos legislativos no sentido do abandono da ideologia ressocializadora como função exclusiva do Direito Penal e de recuperação de um sistema tradicional garantista que se definiu como "neoclássico". Trata-se de uma tentativa de retomar uma vinculação com os princípios liberais clássicos (vinculados tradicionalmente à teoria da prevenção geral) de previsibilidade, segurança jurídica, igualdade e estrita proporcionalidade que a ideologia ressocializadora havia colocado em questão ${ }^{236}$.

Afirma Sánchez que, dentre os inúmeros autores ${ }^{237}$ que se englobam sob a chamada corrente neoclássica, todos trazem em comum a tentativa de combater a ideia de que a medida da pena se possa ver incrementada em função dos prognósticos que se possa fazer sobre os sucessos e evoluções futuras com base no tratamento do delinquente.

\footnotetext{
“Os autores denominados neoclássicos ou proporcionalistas têm propugnado uma concretização nas características do fato à hora de determinar a pena porque entenderam que as tendências preventivo-especiais existentes até os anos setenta e oitenta em países como os EUA, Suécia ou Finlândia concediam ao órgão judicial uma discricionariedade excessiva que estava conduzindo a uma aplicação desigual do ordenamento jurídico-penal e a um trato discriminatório de determinados indivíduos ou tipos de indivíduos” ${ }^{238}$.
}

A ideia central da teoria da pena proporcional ao fato é relacionar a medida da pena com base na ideia de prevenção geral limitada pela culpabilidade e a proporcionalidade com o fato delitivo. Orienta-se, assim, retrospectivamente - e não para o futuro (como no modelo de ênfase preventiva especial e suas asserções sobre a análise da periculosidade do delinquente). Nas palavras de Feijoo Sánchez:

\footnotetext{
“A ideia essencial é que se trata de buscar qual é a pena justa que o autor deve suportar por seu fato mais que centrar em buscar com a pena influências no próprio autor ou em terceiros” 239 .
}

Vide MARTINSON, Robert. What Works? - questions and answers about prision reform. Disponível em: www.nationalaffairs.com.

${ }^{236}$ Cf. SÁNCHEZ, Bernardo Feijoo. Op. cit., p. 5-6.

${ }^{237}$ Especialmente os trabalhos de Von Hircsh e os desenvolvimentos ulteriores de Tatjana Hörnle.

${ }^{238}$ Idem, ibidem, p. 6.

${ }^{239}$ Idem, ibidem, p. 7. 
Tatjana Hörnle, em seus desenvolvimentos sobre uma teoria da pena proporcional, propõe a eliminação de critérios relacionados à prevenção especial e à personalidade do autor $^{240}$. As críticas da autora voltam-se, sobretudo, ao aumento irresponsável da pena com base em elementos relacionados ao agente. Sob o pretexto da prevenção especial, afirma, as cortes apenam muito mais severamente:

\begin{abstract}
"Quando se valora a biografia do delinquente, as cortes põem dura ênfase nos antecedentes e incrementam as penas de acordo com isso. As penas mais altas para reincidentes, provavelmente são, em certa medida, uma expressão de desamparo, mas também parte de uma estratégia de neutralização, isto é, de prevenção especial: delinquentes reincidentes recebem substancialmente tempos mais longos de encarceramento para 'mantê-los encerrados por segurança'. Isso é particularmente problemático quando o crime pelo qual condenam o delinquente não é um delito sério, somente a repetição de um delito de relativamente menor importância que, em si mesmo, não justificaria um longo prazo de encarceramento. Com o princípio da proporcionalidade, o papel tão dominante dos antecedentes pode ser desafiado. Se o delinquente foi condenado previamente, isto pode ser tido em conta (principalmente podem dar-se castigos mais leves aos delinquentes principiantes ou aqueles que o fazem pela segunda vez) mas não conduzirá a aumentos drásticos no castigo”241.
\end{abstract}

Hörnle, rechaçando o mandato da prevenção especial como única forma de humanizar o sistema de penas, admite ser possível prestar atenção a certas circunstâncias especiais na vida do delinquente e do delito, porém, dentro de uma teoria da proporcionalidade $^{242}$.

Sua conclusão é no sentido de que a teoria da determinação da pena, por muito tempo, omitiu-se em expressar claramente qual o castigo justo para um delito específico, porque a prevenção foi considerada como o elemento morigerador da pena real. Dessa

\footnotetext{
${ }^{240}$ Mais precisamente, a autora deixa em aberto a possibilidade da utilização de elementos de prevenção especial, sobretudo em casos nos quais se propõem penas leves, fixadas abaixo das chamadas "penas proporcionadas". Essencialmente, a autora parte de uma ideia de proporcionalidade com a gravidade do delito, mediante a substituição do foco sobre a "culpabilidade" para a "gravidade do fato": “(...) a noção de proporcionalidade tem que ser o ponto de partida. Unicamente quando se tem uma ideia de qual deveria ser a pena proporcional é que se pode discutir se e por que se pode ir e quanto, por abaixo desta". Tradução livre. Op. cit., p. 36.

${ }^{241}$ HÖRNLE, Tatjana. Tradução livre. Op. cit., p. 33.

${ }^{242}$ Idem, ibidem, p. 31.
} 
forma, propõe o estabelecimento de critérios mais específicos para uma sentença “justa”, uma vez que, para a prática judiciária, os juízes necessitam de critérios a respeito de quais circunstâncias do crime tornam cada um dos delitos mais ou menos graves ${ }^{243}$.

O que, para a autora, faltava na Alemanha era uma aproximação da ideia de “sentença justa” em forma de princípios, porquanto a literatura leiga durante muito tempo limitou-se a reproduzir a teoria do espaço de jogo, da qual trataremos em seguida.

A ênfase a ser dada no processo de determinação da pena, segundo os desenvolvimentos de Hörnle, está na perspectiva da vítima. Para aferir a gravidade do delito, a perspectiva da vítima facilita a valoração racional da severidade do delito. Por razões práticas e conceituais, é preferível basear as decisões ao sentenciar na perspectiva da vítima, em lugar de utilizar imprecisas noções de comunidade ou ordem legal ${ }^{244}$.

Esta decisão sobre quais são os fatores determinantes no processo de sentenciar deve ser encarada sob uma perspectiva, o que induz à seguinte pergunta: perspectiva de quem? Da comunidade ou da vítima? Para a autora, um ponto de vista coletivo seria difícil de aplicar na prática porque “é impossível medir o grau em que o delito perturba a ordem social e legal”245. Além disso, é difícil definir o conceito de comunidade, especialmente dentro de uma população com diferentes interesses e opiniões.

A ideia de Hörnle é de que uma importante função da condenação se relaciona com sua mensagem para a vítima: o maior receptor com interesse na declaração da responsabilidade é a pessoa afetada mediante o delito ${ }^{246}$.

Ademais disso, a perspectiva da vítima para a análise do dano atuaria como uma ferramenta valiosa para analisar a valoração intuitiva da severidade dos delitos contra os

\footnotetext{
243 "Ao ditar sentenças, tem de se decidir se, por exemplo, o homicídio negligente é pior, igual ou menos mal que o lesionar intencionalmente alguém”. Tradução livre. Ibidem, p. 34.

${ }^{244}$ Idem, ibidem, p. 90.

245 Tradução livre. Idem, ibidem, p. 85-86.

${ }^{246}$ Idem, ibidem, p. 88. Importa destacar a distinção que a autora faz entre responsabilidade e culpabilidade. A responsabilidade estaria referida ao fato criminal, sua antijuridicidade e suas consequências, julgadas de uma perspectiva exterior. A culpabilidade significa avaliar as deficiências pessoais do delinquente desde uma perspectiva interna. Assim, a autora entende que uma avaliação da vítima é relevante para a valoração do grau de responsabilidade (aspecto externo do fato).
} 
indivíduos. Para tanto, aponta que é necessário um critério comum para medir o dano dentro de uma categoria homogênea na classificação de delitos, segundo sua gravidade ${ }^{247}$. No entanto, esse critério não deve ser individual, ou seja, uma avaliação subjetiva da vítima, mas um critério normatizado, a respeito dos recursos que influam na qualidade de vida.

A perspectiva da vítima também serve, de acordo com Hörnle, para clarificar as circunstâncias ditadas pela lei penal. Assim, a concreta colocação da vida da vítima em perigo incrementa o dano, assim como a conduta especialmente violenta contra a vítima ${ }^{248}$.

Critérios, comumente vistos nas sentenças judiciais sob a denominação de "energia criminal”, também podem ser esclarecidos desde uma perspectiva da vítima. Se o agente atuou premeditadamente ou demonstrando maior audácia por atuar em plena luz do dia, nenhuma diferença deve fazer com relação à severidade da pena, posto que, sob o ponto de vista da vítima, não exerceu nenhum papel para elevar a severidade do delito ${ }^{249}$. O mesmo se diga com relação à conduta do delinquente de ocultar suas ações depois de cometido o delito. A conduta do autor para a vítima é irrelevante e, nas palavras de Hörnle, " $a$ responsabilidade do fato finaliza quando o fato finaliza" ${ }^{250}$.

Também problemática é a questão do apenamento mais severo com base em condenações anteriores. Para a autora, não fica claro por que razão condenações anteriores ou do crime cometido por organizações criminosas devem importar para a fixação da pena: “Desde a perspectiva da vítima”, afirma, “as condenações prévias importam tão pouco como o estado organizacional do delinquente” ${ }^{251}$.

\footnotetext{
${ }^{247}$ Como exemplo, cita a sugestão de Von Hirsch do critério da qualidade de vida, que ele divide em quatro níveis: mera subsistência, bem estar mínimo, bem estar adequado e bem estar intensificado. "Dentro deste marco, a gravidade de um delito depende de seu impacto sobre as condições essenciais para a qualidade de vida da vítima”. Tradução livre. Ibidem, p. 95-96.

${ }^{248}$ Idem, ibidem, p. 104.

249 Ainda a respeito da premeditação, a autora acrescenta: "Se o planejamento ocorre na esfera interna do delinquente, que é, se ele descobre e muda de planos em sua mente sem tocar a esfera da vítima na etapa pré-delitual, a responsabilidade não está intensificada”. Tradução livre. Idem, ibidem, p. 107.

${ }^{250}$ Trad. livre. Idem, ibidem, p. 108.

${ }^{251}$ Trad. livre. Idem, ibidem, p. 111.
} 
A teoria da proporcionalidade pelo fato e, especialmente, o posicionamento de Hörnle, não estão isentos de críticas e objeções da doutrina ${ }^{252}$. Conforme aponta Feijoo Sánchez, as principais críticas que se podem formular à denominada teoria “neoclassicista”, ulteriormente desenvolvida por Hörnle, estão em seu caráter extremamente individualista ao tomar em consideração para a determinação da pena só a perspectiva da vítima, descuidando da dimensão do fato para a ordem social ${ }^{253}$.

Além disso, falta-lhe a sustentação de uma teoria sobre a função social da pena. A crítica de Feijoo Sánchez reside exatamente no fato de não ser possível determinar a medida da pena se esta não se encontra referida a um fim: "A determinação ou a individualização judicial da pena não deixa de ser uma concretização da teoria dos fins ou dos critérios gerais de legitimação da pena" ${ }^{254}$.

No entanto, o "neo-proporcionalismo" apresenta aspectos positivos que merecem destaque e que, para Feijoo, podem contribuir para o desenvolvimento de uma teoria da individualização da pena útil, especialmente para a prática forense espanhola. Em primeiro lugar, ela elimina a arbitrariedade ao vincular os critérios de determinação da pena aos mesmos critérios que servem para decidir se se impõe a própria pena. Dessa forma, os fatores que servirão para a determinação da pena estarão vinculados ao conceito material de delito ${ }^{255}$.

A teoria da determinação da pena de Hörnle estabelece uma orientação da determinação da pena à teoria do injusto ou ao injusto culpável, considerando que a determinação da pena deve fazer-se depender só da gravidade do fato, é dizer, da dimensão do desvalor do fato. O decisivo passa a ser, assim, identificar os fatores que em casos concretos permitem realizar adequadamente o desvalor do fato delitivo ${ }^{256}$.

\footnotetext{
${ }^{252}$ E também a Von Hirsch e Bernd Schünemann, defensores da teoria proporcional ao fato.

253 "A teoria da proporcionalidade pelo fato, ao conceder-lhe um peso excessivo à afetação de interesses individuais, não pode explicar muitos fatores de determinação da pena existentes em nosso ordenamento nem fatores que resultam decisivos na prática judicial e aos quais parece que não se deve renunciar". Tradução livre. Op. cit., p. 9.

${ }^{254}$ Trad. livre. Idem, ibidem, p. 8.

${ }^{255}$ Idem, ibidem, p. 8.

${ }^{256}$ Cf. SÁNCHEZ, Bernardo Feijoo. Tradução livre. Op. cit., p. 8.
} 
Em resumo, esta teoria permite excluir fatores de incremento da pena que carecem de vinculação normativa com o injusto ou o culpável, racionalizando a atividade de determinação da pena e permitindo uma melhor comparação entre casos para tentar evitar a arbitrariedade e a insegurança, assegurando um maior controle desse aspecto por parte dos Tribunais Superiores ${ }^{257}$.

Não obstante, a crítica de Feijoo Sánchez persiste tanto quanto ao conceito material de delito para Hörnle, quanto com relação à sua dependência excessiva do desvalor do resultado, reduzindo a gravidade do fato à gravidade do resultado. Por essa razão, o autor entende ser preciso desenvolver, em paralelo, “as linhas fundamentais da teoria jurídica do delito e da teoria da determinação da pena na medida em que esta não é mais que uma diferenciação gradual dos diversos aspectos relevantes daquela” ${ }^{258}$.

No que se refere aos aspectos preventivos especiais, Feijoo Sánchez está de acordo com sua utilização apenas para o fim de permitir a substituição ou suspensão da pena, mas não como critério de determinação da medida da pena em sentido amplo ${ }^{259}$. Essa é, também, a ideia proposta pela teoria do valor de posição ou do emprego, que será tratada a seguir.

\subsubsection{Teoria do valor de emprego}

Se a teoria da pena proporcional ao fato prescinde do enfrentamento da discussão a respeito dos fins da pena, o mesmo não ocorre com as demais teorias formuladas sobre a matéria.

A necessidade desse enfrentamento se atribui ao fato de o Código Penal alemão (§46, StGb) prescrever que, no momento de aplicar a pena, o juiz deverá levar em conta

\footnotetext{
257 "A orientação ao sistema do delito a) facilita teoricamente a fundamentação de por que um determinado fato de determinação da pena deve ser introduzido no catálogo dos dados a tomar em consideração, b) permite a normativização dos fatores de determinação da pena e c) ademais, ajuda a aproveitar o grau de desenvolvimento que alcançou a teoria jurídica do delito". Tradução livre. Idem, ibidem, p. 9.

${ }^{258}$ Tradução livre. Idem, ibidem, p. 10.

259 Aspecto no qual coincide com a teoria da pena exata ou teoria do valor posicional, sobre a qual discorreremos mais adiante.
} 
tanto o ponto de vista da culpabilidade, como o da prevenção. No entanto, o próprio Código não resolve a antinomia dos fins da pena ${ }^{260}$.

Frente a esse problema, a teoria do valor de emprego ${ }^{261}$ propôs elaborar um sistema interpretativo que pudesse reunir coerentemente as duas pretensões legais. O processo de determinação da sanção seria dividido em dois níveis: o juiz, em primeiro lugar, converte o ilícito culpável em um quantum de pena, determina sua duração e gravidade. Reflexões relacionadas com razões de prevenção geral ou especial só poderiam introduzir-se em um segundo passo, em um momento em que o juiz estabelece que tipo de pena deve-se impor e seu modo de cumprimento, pois só se poderia perseguir fins preventivos uma vez que se tenha estabelecido que tipo de pena deve cumprir o autor ${ }^{262}$.

Para Roxin, a teoria do valor de emprego traz uma solução para a antinomia dos fins da pena exatamente por pretender dar conta tanto do ponto de vista da retribuição da culpabilidade, como da prevenção, mas atribuindo a cada um desses elementos um valor de emprego na lei completamente diferente:

\footnotetext{
"A determinação judicial da pena, ou seja, a determinação da magnitude da pena, conforme o art. 46, deve levar-se conforme o grau de culpabilidade, enquanto que a determinação da pena em sentido amplo, ou seja, a decisão sobre a pena privativa de liberdade ou de multa, sobre a suspensão condicional da pena e a liberdade condicional, sobre a admoestação com reserva de pena e a dispensa de pena deve ser fixada igualmente de um modo exclusivo, só por considerações preventivas. Retribuição da culpabilidade e prevenção aparecem, aqui, portanto, como graus sucessivos e independentes da determinação ${ }^{263, "}$
}

Contudo, algumas objeções são oponíveis à teoria do valor de emprego, como refere o próprio autor ${ }^{264}$. Em primeiro lugar, segundo a legislação alemã, na magnitude da

\footnotetext{
${ }^{260}$ Cf. ROXIN, Claus. Prevención y determinación de la pena, p. 239.

${ }^{261}$ Roxin aponta como fundador da teoria do valor de emprego Heinrich Henkel e como atual defensor, Horn. Idem, Ibidem, p. 241.

${ }^{262}$ Cf. ZIFFER, Patricia. Consideraciones acerca de la problemática de la individualización de la pena, p. 42.

${ }^{263}$ ROXIN, Claus. Op. cit., p. 241-242.

${ }^{264}$ Cumpre apontar a advertência de Roxin de que a fórmula da teoria do valor de emprego surgiu como resultado de uma interpretação do direito então vigente, antes da reforma do Projeto Alternativo o que, segundo ele, impede utilizá-la hoje com base do direito vigente. Idem, ibidem, p. 243.
} 
pena também devem desempenhar um papel outros pontos de vista que só podem ter natureza preventiva. Do contrário, o legislador teria dito, por exemplo, que a pena se determinará com atenção à culpabilidade do réu e nada mais. Assim, afirma, "está fora de toda dúvida que a intenção do legislador era deixar certo espaço, com a ajuda de uma fórmula básica eleita, as considerações preventivas na hora de determinar a magnitude da pena" ${ }^{265}$.

Ademais, tendo em vista que a lei alemã dispõe que o juiz deve ter em conta na hora de determinar a pena os efeitos que cabem esperar para a vida futura do réu em sociedade, a prescrição legal não se mostra compatível com uma fórmula que prescinda desses efeitos na hora de determinar a magnitude da pena ${ }^{266}$.

Por fim, o autor menciona uma objeção teleológica: se a determinação da pena se rege pelos fins da pena, não há nenhum critério valorativo evidente que possa justificar que esses fins se determinem de modo completamente distinto para distintas fases, já que em todos os casos se trata, na mesma medida, de determinação da pena ${ }^{267}$.

Por essa razão, conclui que somente por meio da culpabilidade é impossível alcançar-se uma magnitude exata da pena. Se se renuncia a completá-la com finalidades preventivas, então a magnitude concreta da pena só pode fixar-se arbitrariamente, o que seria pior do que a solução orientada por critérios preventivos, mesmo que sejam também critérios inseguros. Para ele, determinar a magnitude exata da pena exclusivamente pela culpabilidade é irrealizável ante a inexistência de uma correspondência exata entre pena e culpabilidade $^{268}$.

\footnotetext{
${ }^{265}$ Dentre os fatores mencionados pelo § 46 [2], StGB, estão elencadas as seguintes circunstâncias: os motivos e fins do réu, a atitude que deriva do fato e a vontade emprega nele, o grau de infração ao dever, a classe de execução e os efeitos culpáveis do fato, a vida anterior do réu anterior à comissão do fato, suas circunstâncias pessoais e econômicas, assim como seu comportamento após o fato, especialmente seus esforços por reparar o dano causado. Tradução livre. Idem, ibidem, p. 239 e 243.

266 "Entre os fatores de determinação da pena (as chamadas causas 'reais' de determinação da pena) que o parágrafo $2^{\circ}$ contém, cita-se uma série completa de circunstâncias que não determinam exclusivamente a magnitude da culpabilidade, senão que em todo ou em parte se orientam em necessidades preventivas, então não é compatível com esse preceito uma concepção que priva a prevenção de toda a significação à hora de determinar a magnitude da pena, pois o catálogo contido no parágrafo segundo se refere inequivocamente à determinação da pena contida no parágrafo primeiro". Tradução livre. Idem, ibidem, p. 246 (destaques nossos).

${ }^{267}$ Idem, ibidem, p. 247.

${ }^{268}$ Idem, ibidem, p. 249.
} 
Não obstante, Roxin afirma, com apoio em Bruns, que não se deve rechaçar de todo a teoria do valor de emprego, pois ela contém dados importantes que vão mais além do que aceita a doutrina dominante, podendo conseguir-se, em virtude dela, um modelo das causas finais da determinação da pena capaz de alcançar um consenso geral ${ }^{269}$. Em primeiro lugar, porque considera absolutamente correto que, ao determinar a pena em sentido amplo, não devem desempenhar qualquer papel os pontos de vista da retribuição da culpabilidade, uma vez que são irrelevantes, segundo o autor, as considerações extraídas da culpabilidade nas decisões tomadas para a liberdade condicional, dispensa de pena e admoestação com reserva de pena ${ }^{270}$.

Em segundo lugar, porque a teoria do valor de emprego exclui qualquer consideração de prevenção geral independente da culpabilidade, quando essas considerações conduzam a uma agravação da pena ${ }^{271}$. Assim, a teoria do valor de emprego tem razão quanto à afirmação de que a prevenção geral não tem uma significação autônoma na hora de determinar a pena.

O autor, que se declara abertamente partidário da teoria do espaço de jogo ou da margem de liberdade pretende demonstrar que a consideração dos interesses preventivos especiais na determinação da magnitude da pena (hipótese que a teoria do valor de emprego rejeita), em virtude dos conhecimentos criminológicos existentes até agora, é absolutamente praticável e lógica ${ }^{272}$.

“Certamente, a função limitadora do princípio da culpabilidade proíbe que se
possa impor por razões de prevenção especial uma pena superior a que permite o
marco da culpabilidade; mas este marco mesmo sim pode ser completado com

${ }^{269}$ Idem, ibidem, p. 250.

270 "Seria inadmissível interpretar com a ajuda de considerações extraídas do âmbito da culpabilidade a 'defesa do ordenamento jurídico', cuja necessidade possa impedir que uma pena privativa de liberdade se transforme numa multa”. Tradução livre. Idem, ibidem, p. 250.

${ }^{271}$ Importa anotar que Roxin não vê inconstitucionalidade alguma em se estabelecer um agravamento de pena motivado por razões de prevenção geral, desde que se mantenha o marco correspondente à culpabilidade. Por outro lado, ele vê nisso uma infração à própria lei, em razão do que foi introduzido no Código Penal alemão. Quando o § 46, StGB prescreve expressamente ter-se em conta as necessidades de prevenção especial e não menciona, em troca, nada a respeito da prevenção geral, isso só permitiria a interpretação de que na determinação da pena correspondente à culpabilidade já não se deve ter em conta as necessidades de prevenção geral. Idem, ibidem, p. 254.

${ }_{272}$ Roxin interpreta a culpabilidade como fundamento da determinação da pena de tal forma que o marco para a determinação concreta da pena se forma pela culpabilidade e, dentro da margem de liberdade, decidam as considerações preventivas sobre a magnitude da pena. 
critérios preventivos especiais e é também criminologicamente desejável e juridicamente admissível impor uma pena orientada pela prevenção especial, inferior à que corresponderia pela culpabilidade ${ }^{273,}$.

Assim, resume suas considerações a respeito da prevenção na determinação da pena em uma concepção que qualifica como "uma teoria do valor de emprego modificada pela prevenção especial” ${ }^{274}$ :

\footnotetext{
"A modificação consiste em reconhecer num marco de culpabilidade na determinação da pena conforme o §46, StGB, mas esse marco se completa, dentro do possível, por necessidades preventivas especiais" ${ }^{275}$.
}

Este, para ele, seria o inicio do esboço de um modelo das causas finais da determinação da pena, além de servir de base aos partidários da teoria da margem de liberdade e da teoria do valor de emprego. E com essas premissas, adiantam-se as formulações básicas da chamada teoria do espaço de jogo (ou teoria da margem de liberdade) originada da jurisprudência alemã e fecundamente desenvolvida por autores europeus, conforme se verá a seguir.

\subsubsection{Teoria do espaço de jogo ou da margem de liberdade}

A teoria do espaço de jogo foi desenvolvida pela jurisprudência alemã a partir da atual redação do § 46, StGB. A corte Suprema alemã declarou, em decisão tomada em 1954, que não é possível determinar com precisão que pena é proporcional à culpabilidade do delinquente:

\footnotetext{
"Existe sempre uma gama de possibilidades para determinar a entidade da culpabilidade que se adequa a cada crime em particular. O juiz deve individualizar a pena, dentro desse marco global. Para realizar essa determinação, o juiz pode utilizar critérios preventivos” 276.
}

${ }^{273}$ Tradução livre. Idem, ibidem, p. 255.
${ }^{274}$ Idem, ibidem, loc. cit..
${ }^{275}$ Tradução livre. Idem, ibidem, p. 236.
${ }^{276}$ Cf. ZIFFER, Patricia. Trad. livre. Op. cit., p. 24. 
Para Patricia Ziffer, o que manifestou esse precedente foi que a prevenção e a justiça podem ser valoradas ao condenar, e que tomar a prevenção em conta é compatível com apenar, baseando-se na culpabilidade do delinquente ${ }^{277}$.

A conceituação da teoria do espaço de jogo por Martín Hernandez parece ser a que melhor a define:

\begin{abstract}
“(...) em essência, supõe que o juiz deve determinar uma pena adequada à culpabilidade do autor, que se materializa em um espectro, espaço ou âmbito de possíveis penas que abarca desde uma pena já adequada à culpabilidade até uma pena ainda adequada à culpabilidade. Dentro do dito ‘espaço de jogo' o juiz deve logo fixar a quantia de pena específica sobre a base de considerações preventivas, sem transbordar para cima nem para baixo os limites estabelecidos em virtude da medida da culpabilidade”278.
\end{abstract}

Não é raro, contudo, encontrar defensores da teoria do espaço de jogo que, sobretudo em virtude do que dispõe o Código Penal alemão, admitem a fixação da pena para abaixo do marco da pena já adequada à culpabilidade, em razão de critérios preventivo-especiais $^{279}$. Tal ocorreria quando, por exemplo, a fixação da pena correspondente à culpabilidade pudesse ter um efeito contrário à socialização do agente ${ }^{280}$.

Questão tormentosa na teoria da margem de liberdade - que é a teoria que vem sendo defendida pela generalidade da doutrina alemã — é o conceito da culpabilidade para fins de medida da pena ${ }^{281}$. Não apenas com relação ao seu conceito material, mas também

\footnotetext{
${ }^{277}$ Idem, ibidem, loc. cit..

278 Tradução livre. HERNÁNDEZ, Martín Besio. Los criterios legales y judiciales de individualización de la pena, p. 138.

${ }^{279}$ O $\S 46$, StGB aduz que: “1) A culpabilidade do réu é fundamento da determinação da pena. Devem terse em conta os efeitos que cabe esperar tenha a pena para a vida futura do réu na sociedade”. Nesse sentido, ROXIN, Claus. Op. cit., p. 240.

${ }^{280}$ Conforme será esclarecido mais adiante, a prevenção especial, hoje em dia, "é entendida majoritariamente em sua vertente positiva, isto é, associada às ideias de ressocialização, reabilitação, readaptação ou similares”, muito embora, tecnicamente, a prevenção especial cumpra três tarefas distintas: a intimidação pessoal, a inocuização (ambos integrantes da prevenção especial negativa) e a ressocialização (prevenção especial positiva). Cf. HERNÁNDEZ, Martín Besio. Op. cit., p. 78.

${ }^{281}$ Conforme a crítica de Tatjana Hörnle, “(...) falta um debate de anos sobre o conceito de culpabilidade doß 46, I, StGb que possa comparar-se à discussão do conceito de culpabilidade na teoria da delito”.
} 
com relação aos elementos que devem ser tomados em conta ou que têm relevância para a valoração dessa circunstância.

Para alguns autores (dentre os quais, elegemos Figueiredo Dias como representante), a culpabilidade da medida da pena é a mesma culpabilidade da teoria do delito $^{282}$. A culpa relevante para a medição da pena haverá de ser exatamente aquela mesma culpa que releva na determinação do sentido e dos fins da pena e da sua aplicação $^{283}$.

Para o referido autor, a culpa fornece apenas um limite máximo de pena que não pode ser ultrapassado; a medida da pena vem antes a ser determinada em último termo por considerações de prevenção, sendo por essa via que se torna também possível (e necessário) dar relevo a muitos fatores relacionados com o tipo de ilícito.

Criticando o posicionamento majoritário da doutrina penal alemã, Figueiredo Dias afirma que em todas as teorias alemãs sobre a determinação da pena radica "o mesmo erro básico e passível, por isso, da mesma crítica de fundo":

\footnotetext{
"O que sucede é que qualquer delas se nutre da ideia de que o critério único, ou em todo o caso, verdadeiramente essencial e decisivo, de medição da pena é a culpa do agente, enquanto considerações de prevenção assumem apenas um relevo secundário ou consequencial naquele processo. E se uma tal posição não deve surpreender quando proveniente de todos aqueles que continuam a ver na retribuição ou compensação da culpa uma das finalidades, ou mesmo a finalidade por excelência da pena, já ela não deixa de constituir uma íntima contradição,284.
}

Em sentido oposto, Tatjana Hörnle afirma que a culpabilidade da teoria do delito nada tem em comum com a culpabilidade para a medida da pena. Para ela, no momento de

Tradução livre. La concepción anticuada de la culpabilidad en la jurisprudencia y doctrina tradicionales de la medicón de la pena, p. 401-402.

${ }^{282}$ É importante mencionar que o art. 71 do Código Penal português prescreve: "A determinação da medida da pena, dentro dos limites definidos na lei, é feita em função da culpa da agente e das exigências de prevenção". Assim, ressalvadas as diferenças, culpa e prevenção estão presentes tanto no Código Penal alemão, como no Código Penal português.

${ }^{283}$ DIAS, Jorge de Figueiredo. Sobre o modelo de determinação da medida da pena, p. 218.

${ }^{284}$ Idem, ibidem, loc. cit.. 
concretizar o conteúdo semântico do §46, StGB, há que se ressaltar, antes de tudo, uma constatação essencial: a adesão a uma valoração retrospectiva do fato como fundamento da medição da pena e jamais partir-se de considerações preventivas ${ }^{285}$.

Para Hörnle, hoje é indiscutível que, no referido artigo do Código Penal alemão, não se pode entender como uma referência direta exclusiva à categoria "culpabilidade” no sentido do sistema do delito: a chamada culpabilidade na medição da pena não é idêntica à culpabilidade como fundamento da pena: "A pena adequada à culpabilidade tem que orientar-se à gravidade do fato e ao grau de culpabilidade pessoal do autor" ${ }^{286}$.

Independentemente das finalidades da pena que um determinado ordenamento jurídico adote (e mesmo dos distintos critérios de aferição da culpabilidade, seja como retribuição, seja como prevenção geral), importa concluir que, para a teoria do espaço de jogo, a culpabilidade (pelo fato) estabelece um marco mínimo e máximo, dentro do marco legal, definindo dois limites: o de uma pena já adequada à culpabilidade e o de uma pena ainda adequada à culpabilidade.

Dentro desse espaço ou espectro fornecido pela culpabilidade, irão “jogar” elementos relacionados à prevenção que, por sua vez, devem respeitar aqueles limites mínimo e máximo fornecidos pela culpabilidade.

Não obstante, conforme se verá mais adiante, em virtude de finalidades preventivoespeciais (sobretudo para evitar a não dessocialização do agente), admite-se que a pena venha a ser fixada aquém do limite mínimo da culpabilidade. No entanto, nenhum elemento relacionado a finalidades preventivo-especiais — segundo uma concepção moderna da culpabilidade — poderá ser utilizado como critério de medida da culpa ${ }^{287}$.

\footnotetext{
${ }^{285}$ Por tal razão, afirma que a valoração retrospectiva do fato poderia ter sido formulada pelo legislador de outra maneira, por exemplo, mediante uma referência à gravidade do fato. Tradução livre. HÖRNLE, Tatjana. Op. cit., p. 46. O mesmo se pode dizer a respeito do modelo de determinação da pena brasileiro que não faz qualquer referência à gravidade do fato e deixa o julgador livre para inserir sob o conceito de "culpabilidade" elementos, mais das vezes, relacionados com aspectos de valoração moral ou relativos à personalidade do agente.

${ }^{286}$ Idem, ibidem, p. 49.

${ }^{287}$ Nesse sentido, concorda também Anabela Miranda: “Uma correta colocação dos termos da problemática só se conseguirá, entretanto, quando, por um lado, não se continuar apegado a uma fundamentação $e$ sentido do direito penal que vê na culpa e na sua retribuição a sua finalidade básica essencial e que coloca este entendimento na base do processo de determinação da medida da pena, e por outro lado, quando se
} 
Também a teoria da margem de liberdade recebe críticas doutrinárias. Em especial, de Anabela Miranda, cujo posicionamento em termos de determinação da pena é da prevenção geral positiva.

Para a autora, a teoria da margem de liberdade pode ser uma "pura fórmula vazia de conteúdo" que apenas aparentemente encontrou uma solução para a antinomia dos fins da pena. Afirma que a teoria não explica por qual razão a retribuição da culpa fornece uma moldura e, por outro lado, deixa ainda para resolver, em um segundo momento, duas ordens de questões: como se ordenam os fins preventivos no âmbito da moldura da culpa e como se deve preencher a moldura da culpa quando não há que se considerar qualquer fim da pena ${ }^{288}$.

A isso se pode acrescentar que a teoria da margem de liberdade não resolve a questão relativa aos critérios que devem ser recolhidos do fato e que serão relevantes para o estabelecimento da moldura da culpa. A falta de critérios que possam ser manejados pelo juiz é o maior problema da teoria da determinação da pena, e que mantem a prática da individualização da pena ainda carente de uma racionalidade mínima que afaste a arbitrariedade e a intuição dos juízes.

Nessa direção também caminha a crítica de Demetrio Crespo, para quem, o juiz, frente a uma operação extremamente complexa, deveria poder discernir entre a numerosa quantidade de circunstâncias do fato, quais e com que peso determinaria a medida da culpabilidade. Além disso, essas mesmas circunstâncias seriam em boa parte relevantes para determinar que influência preventiva-especial frente ao autor estaria indicada no caso concreto e que perigos existiriam para sua dessocialização. Por último, haveria que se considerar ditas circunstâncias desde a perspectiva de evitar lesar a confiança jurídica da população ${ }^{289}$.

levar às últimas consequências o abandono da teoria tradicional das circunstâncias. Se assim for, nada impedirá que relevem para a determinação da medida da pena muitos factores, não pela via da culpa, mas pela via da prevenção". A determinação da medida da pena privativa da liberdade, p. 515.

${ }^{288}$ Idem, ibidem, p. 541.

289 DEMETRIO CRESPO, Eduardo. Notas sobre la dogmática de la individualización de la pena, p. 38. 
Afirma, por fim, que o problema fundamental da teoria do espaço de jogo é a determinação dos critérios que devam entrar em consideração para dotar de conteúdo essa margem de liberdade. Para ele, parece claro que deverão ser critérios de prevenção especial majoritariamente ${ }^{290}$.

Uma racionalização na utilização dos critérios legais (inclusive da culpabilidade), especialmente os de natureza preventivo-especial, será objeto de análise mais minuciosa no item 3.3 deste Capítulo.

\subsubsection{Teoria da pena exata ou pontual}

Para a teoria da pena exata existe uma única pena completamente delimitada que corresponde à culpabilidade do autor. Essa teoria nega, portanto, o conceito de um espaço de jogo, porque entende que existe uma única pena justa e adequada à culpabilidade ${ }^{291}$.

A pena deve ser exclusivamente fixada pela medida da culpa, cuja valoração se dá em uma medida de pena rigorosamente fixada em um ponto definido da moldura penal abstrata (marcos mínimo e máximo). As considerações preventivas, de caráter meramente marginal para esse processo, são realizadas dentro desse âmbito, de acordo com o ponto de vista da culpa. Daí porque algumas críticas versem no sentido de que essa teoria e a teoria da margem de liberdade acabam resultando na mesma coisa.

Os partidários da pena exata, diante da disposição do §46, I, StGB, terão de admitir, na prática, o mesmo resultado a que chega a teoria da margem de liberdade, uma vez que, não obstante se admitisse que a culpa fornece uma medida da pena fixa, sempre teriam de se admitir variações para acima ou para baixo desse ponto, provocadas pelas exigências de prevenção ${ }^{292}$.

\footnotetext{
${ }^{290}$ Idem, ibidem, loc. cit..

${ }^{291}$ Demetrio Crespo anota que, sobre a teoria da pena exata, se diz constituir uma ficção jurídica, já que, devido à insuficiência da capacidade humana de conhecimento, tal pena não pode ser determinada exatamente. Para o autor, não se trata de haver uma falta de conhecimento a respeito da magnitude da culpabilidade, mas que tal magnitude exata não existe em absoluto. Op. cit., p. 34.

${ }^{292}$ Cf. RODRIGUES, Anabela Miranda. Op. cit. p. 498. A anotação da autora é de Roxin. Op. cit, p. 240.
} 
A principal crítica apontada por Anabela Miranda à teoria da pena pontual é a de que, na medida em que ela parte de uma ideia de culpa “ideal”, encontra limites no próprio conhecimento humano. Além disso, a autora entende, com Roxin, que para a teoria da pena exata ou pontual tem importância uma “concepção retributiva da culpa, afastada da atual compreensão do direito penal, e que por isso não tem lugar na determinação da medida da pena" 293.

“A objeção fundamental a levantar-se é a de que ela coloca na base da determinação da pena a compensação da culpa — que (mesmo desprovida de raízes mais ou menos metafísicas) não ocupa mais o lugar de fundamento no moderno direito penal de prevenção - e, assim, uma concepção da pena retributiva" $^{294}$.

\subsubsection{Outros posicionamentos}

O presente trabalho não tem como escopo esgotar a matéria a respeito das teorias da determinação da pena. Como já inicialmente exposto, a análise das principais premissas em que se baseiam as teorias que vêm se desenvolvendo na Alemanha e na Espanha (por exemplo), importa para colaborar para uma maior racionalização do nosso sistema de aplicação da pena.

Nessa medida, impõe-se mencionar ainda alguns outros posicionamentos que não se encaixam exatamente nas teorias antes detalhadas, mas que, evidentemente, guardam relação direta daqueles trabalhos ou desenvolveram-se a partir deles.

\subsection{O sistema dogmático de determinação da pena de Silva Sánchez}

É um exemplo de algumas posturas "heterodoxas” o entendimento de Jesús María Silva Sanchez, para quem, para evitar-se a arbitrariedade ou o puro "decisionismo" judicial, é necessário que a política criminal que se realiza no processo de determinação da

\footnotetext{
${ }^{293}$ Idem, ibidem, p. 500.

${ }^{294}$ Idem, ibidem, loc. cit..
} 
pena se dê por vias dogmáticas. Sob essa premissa, propõe um modelo de teoria da determinação da pena equivalente à dimensão quantitativa de um sistema da teoria do delito, que prescinde da aplicação dos fins do Direito Penal na individualização judicial da pena.

Para esse fim, sustenta que os elementos dogmáticos da teoria do delito devem estabelecer uma relação direta com os critérios a serem utilizados na determinação da pena. Como consequência, elementos alheios ao suporte categorial da teoria do delito deveriam ser eliminados nesse processo.

A busca da pena adequada à culpabilidade, para ele, é uma prossecução da qualificação do fato como delito e, portanto, depende das categorias do injusto objetivo (da ação e do resultado), do injusto subjetivo e da culpabilidade. Como são polêmicas essas próprias categorias da teoria do delito, o método de quantificação do injusto dependerá do conceito de injusto de que se parta ${ }^{295}$.

A respeito do juízo de culpabilidade, Silva Sanchez adverte que não poderá levar a um incremento de pena já alcançado com a realização do fato. Isso porque, segundo afirma, hoje, majoritariamente, estão abandonadas as teorias da culpabilidade centradas na reprovação do caráter ou da atitude interna do agente. O juízo de culpabilidade, entendida como culpabilidade pelo fato, não poderá incrementar o merecimento de pena já alcançado com a própria realização do fato ${ }^{296}$.

Da mesma forma, circunstâncias do fato que não guardam correspondência categorial com a teoria do delito, não deveriam ser relevantes para a individualização da pena (como comportamentos posteriores ao fato, nível de sensibilidade à pena, etc.) ${ }^{297}$.

A complexa proposta de Silva Sanchez busca a elaboração de uma escala quantitativa de subtipos (classes de realizações típicas), que estejam ordenadas em função

\footnotetext{
${ }^{295}$ SILVA SÁNCHEZ, Jesús María. La teoria de la determinación de la pena como sistema (dogmático): un primer esbozo, p. 8.

${ }^{296}$ Idem, ibidem, loc. cit..

${ }^{297}$ Idem, ibidem, loc. cit..
} 
de sua gravidade às diversas formas de realização de um mesmo tipo ${ }^{298}$. Injusto, culpabilidade e punibilidade constituem grandezas graduáveis. Assim, a determinação judicial da pena deve traduzir em uma medida específica de pena o conteúdo de injusto, culpabilidade e punibilidade de um fato determinado ${ }^{299}$. E tal processo deverá se dar mediante a adoção de critérios de valoração e ordenação que examinam os casos a partir da adoção de uma determinada perspectiva ou nível de análise.

A aplicação sistemática dos critérios de valoração permitiria a obtenção de um esquema de análise dos casos que, a sua vez, tornaria possível a ordenação de ditos casos segundo valores idealmente numéricos ${ }^{300}$.

Conforme esclarece Martín Hernández, a proposta de Silva Sánchez constitui, em última análise:

\footnotetext{
“(...) um esquema dogmático de análise da medição da pena de caráter neutro, que dependerá necessariamente dos fins do Direito Penal que incidam na configuração das categorias da teoria do delito. Assim, a determinação da pena só se encarrega de traduzir em uma medida concreta de sanção as categorias dogmáticas da teoria do delito, a configuração destas últimas sob um esquema preventivo ou retributivo influirá necessariamente na medição penal, mas isso é completamente alheio ao labor do juiz e ao esquema metodológico de individualização que se propõe” ${ }^{301}$.
}

\subsection{O sistema normativo de determinação da pena de Patricia Ziffer}

Partindo de um pressuposto estritamente legalista, Patricia Ziffer defende que o princípio da legalidade impõe que, no processo de determinação da pena, somente sejam considerados fatores que surjam de uma valoração coerente das normas jurídicas, o que exclui, desde o princípio, valorações morais acerca dos motivos ou móveis do agente ${ }^{302}$. A

\footnotetext{
${ }^{298}$ Idem, ibidem, p. 10.

${ }^{299}$ Cf. HERNÁNDEZ, Martín Besio. Op. cit., p. 87.

${ }^{300}$ SILVA SÁNCHEZ, Jesús María. Op. cit., p. 10.

${ }^{301}$ HERNÁNDEZ, Martín Besio. Op. cit., p. 88.

302 ZIFFER, Patricia. Op. cit., p.59.
} 
desconsideração de fatores morais parece ser a solução mais adequada também em respeito ao princípio do fato.

Porém, a problemática se instala quando é a própria lei que introduz circunstâncias (p.e.: motivos do crime) as quais só poderiam valorar-se desde um ponto de vista ético, como é o caso de algumas circunstâncias judiciais presentes no nosso art. 59, do CP brasileiro.

Para a autora, parece difícil poder graduar a pena evitando toda valoração moral, mas tampouco lhe parece possível permitir ao juiz que possa introduzir suas próprias pautas éticas. A saída da autora é a seguinte:

\footnotetext{
“O ordenamento jurídico constitui a única pauta a que se pode recorrer, já que é o que reúne os modelos de conduta que podem exigir-se do autor. E para o ordenamento jurídico, uma conduta que está orientada a salvaguardar um bem jurídico não é idêntica àquela que não está. Ainda quando uma conduta não chegue a estar coberta por uma causa de justificação ou de desculpa, se a situação pode ser analogada às previstas por essas causas, resultarão menos graves que se isso não é possível” ${ }^{303}$.
}

Quanto à impossibilidade de tradução em magnitudes fixas dos conceitos valorativos da culpabilidade, a autora defende que isso não justifica que o juiz possa decidir discricionariamente: “O fato de a individualização da pena não poder ser um procedimento racionalizável de forma geométrica não o libera da necessidade que os fundamentos da determinação estejam decididos sem contradições em suas concreções" ${ }^{304}$.

Dessa forma, "se o sistema pressupõe o princípio da culpabilidade em nível constitucional, todo o demais deve ser uma concreção desse princípio” 305.

\footnotetext{
${ }^{303}$ Idem, ibidem, p. 60.

${ }^{304}$ Trad. livre. Idem, ibidem, loc. cit..

305 Trad. livre. Idem, ibidem, loc. cit..
} 
Dentro das diretrizes de medição da pena, a autora aponta, em primeiro lugar, a possibilidade do juiz de ir contra o marco penal abstrato, quando houver evidente inconstitucionalidade na própria lei, afinal, a valoração jurídica do juiz contra o marco penal estará apoiada na interpretação do ordenamento jurídico sendo, portanto, válida.

Em segundo lugar, afirma a proibição de bis in idem: o juiz não poderá tomar em conta na pena em concreto um elemento que já tenha sido tomado em conta "em abstrato" pela lei para qualificar a gravidade do ilícito. O mesmo afirma com relação a valorações preventivas, pois já foram consideradas no marco penal e, se não foram, ficariam fora do âmbito da valoração judicial, pois resultam de considerações estranhas ao fato, pelas quais o autor não pode ser responsabilizado - como no caso do aumento de incidência na sociedade de um determinado delito ${ }^{306}$.

Um dos grandes problemas que a autora aponta nos sistemas legais alemão e argentino (e que se verifica também no sistema de penas brasileiro) é que a lei enumera os fatores que devem ser tidos em conta ao graduar a pena sem dizer se a agravam ou atenuam. A isso se soma que tampouco é evidente em que direção se deve efetuar a valoração e, ademais, é possível imaginar situações em que as mesmas circunstâncias possam agravar ou atenuar a pena, segundo o ponto de vista que se tome ou o delito de que se trate. Para a autora, a decisão não pode tomar outro ponto de apoio que o próprio ordenamento jurídico e argumentar a partir dele ${ }^{307}$.

Além disso, frente aos marcos penais mínimo e máximo, para se escolher a partir de que ponto deverá o juiz agravar ou atenuar a pena, deve-se estabelecer um critério comparativo, ou seja, um caso que sirva de base de comparação. Na Alemanha, para dar solução a esse problema, recorreu-se ao chamado "caso regra”, denominação com a qual se designa o grupo de casos que, segundo a experiência, sempre se repetem. Para os casos de baixo grau de gravidade, seria possível localizar a magnitude do desvalor característico do caso regra no terço inferior da escala penal. Nos casos de gravidade média, a magnitude do

\footnotetext{
${ }^{306}$ Idem, ibidem, passim.

${ }^{307}$ Idem, ibidem, p. 63.
} 
desvalor estaria situada na metade aritmética da escala. Para a autora, a imprecisão desses conceitos é evidente ${ }^{308}$.

Ziffer conclui que o processo de medição da pena pode ser entendido como um processo de

$$
\begin{aligned}
& \text { “(...) elaboração e classificação de informações de distinta classe. Nesse processo } \\
& \text { haverá que definir quais são os fatores relevantes para graduar a pena, determinar } \\
& \text { porque constituem atenuantes ou agravantes frente ao caso concreto e formular a } \\
& \text { classificação desses fatores tendo em conta sua relação com os princípios gerais } \\
& \text { (culpabilidade, fato, legalidade) e finalidade que devem cumprir dentro do } \\
& \text { ordenamento jurídico”309. }
\end{aligned}
$$

Para a autora, que estabelece um sistema que se poderia chamar de "normativo", a determinação da pena deve se dar partindo do marco legal e orientar-se ao encontro de circunstâncias do fato que guardem similitude com a estrutura dos elementos do tipo (que fundamentam ou agravam o ilícito) quando se trata de atribuir-lhes um efeito agravatório e a circunstâncias que guardem similitude com a estrutura das causas de justificação ou exculpantes, quando se trate de atribuir-lhes um efeito atenuante ${ }^{310}$.

\subsection{A prevalência das finalidades de prevenção geral positiva ou a teoria da moldura de prevenção de Anabela Miranda Rodrigues}

Em seu substancioso trabalho de doutoramento, Anabela Miranda Rodrigues analisa com profundidade a questão da determinação da medida da pena. Para o modelo que propõe, parte da premissa de que as finalidades da pena são, primordialmente, a tutela de bens jurídicos e, "na medida do possível”, a reinserção do agente na comunidade ${ }^{311}$. A determinação da pena, portanto, deverá seguir a realização dessas finalidades, sem que ultrapasse a medida da culpa.

\footnotetext{
${ }^{308}$ Idem, ibidem, p. 64

${ }^{309}$ Idem, ibidem, p. 65.

${ }^{310}$ Idem, ibidem, loc. cit..

311 É o que expressamente manifesta o art. 40, 1, do Código Penal português: “A aplicação de penas e medidas de segurança visa à proteção de bens jurídicos e à reintegração do agente na sociedade”.
} 
Seu posicionamento é no sentido da prevalência da prevenção geral positiva também na determinação da pena, entendida esta como a manutenção da confiança na validade da norma jurídica violada ${ }^{312}$. Afirma que a defesa de bens jurídicos não se pode operar por meio da socialização, mas sim, "primordialmente conseguindo o afastamento de outros da prática de crimes” ${ }^{313}$.

Para a autora, a prevenção geral positiva legitima-se na medida em que "a relação inversa a estabelecer entre a pena e a taxa de criminalidade tem a ver sobretudo com o fator certeza da punição e não a sua severidade, por aqui é exatamente o efeito preventivo geral positivo a receber uma comprovação empírica"314.

Estabelecida a primazia da prevenção geral positiva na determinação da pena, a moldura de pena será estabelecida de acordo com a gravidade do fato praticado, esse próprio vinculado diretamente ao abalo produzido sobre as expectativas da comunidade. A moldura de pena (portanto, não uma pena exata) será assim formulada a partir do que a comunidade entende como necessário à tutela das suas expectativas na validade das normas jurídicas (limite máximo). Abaixo dessa medida, outras ainda serão consideradas suficientes pela comunidade para proteger as expectativas de validade das normas (limite mínimo) e incidirão as considerações de prevenção especial voltadas à socialização, as quais somente encontrarão um limite ou no ponto ótimo da realização das finalidades de prevenção geral, ou no limiar mínimo de defesa da ordem jurídica, respectivamente nos casos de carência de socialização ou de não carência de socialização ${ }^{315}$.

Importa advertir com a própria autora que, segundo esse esquema, a pena não tem como coincidir necessariamente com a pena da culpa $^{316}$. Contraditoriamente, afirma que a culpa "será chamada a desempenhar o papel para que está vocacionada num direito penal

\footnotetext{
${ }^{312}$ A justificativa da autora por essa opção é tanto em razão do "renascimento" da prevenção geral positiva entre os autores europeus, como em razão da impossibilidade de intervenção coativa do Estado na esfera individual, o que constituiria um óbice à predileção pela prevenção especial.

${ }^{313}$ Idem, ibidem, p. 547.

${ }^{314}$ Idem, ibidem, p. 554.

315 "O que se observa é que, nesta construção, a pena é efetivamente medida pelo juiz em função das exigências de proteção das expectativas comunitárias na validade da norma jurídica violada - e que tem no processo, como já dissemos, papel primordial”. Idem, ibidem, p. 572.

316 "Consequência que julgamos ser neste momento por demais evidente, conferido que é à prevenção geral positiva um conteúdo próprio, distinto do da culpa”. Idem, ibidem, p. 573.
} 
preventivo em que a pena é efetivamente medida em função das exigências de prevenção - o papel de incontestável limite da pena assim encontrada, que não pode, em caso algum, ultrapassar a medida da culpa”317.

Da mesma forma, os limites da pena definida pela necessidade de proteção de bens jurídicos também não podem ser desrespeitados em nome da realização da finalidade da prevenção especial:

\begin{abstract}
"O desvalor do fato é agora aferido perante um substrato de medida da pena fixado também tendo em conta unicamente a necessidade de pena, pelas exigências individuais e concretas de socialização do agente, sendo certo que na determinação de uma medida de pena socializadora há que entrar em linha de conta com que se deve evitar a dessocialização do agente” ${ }^{318}$.
\end{abstract}

Não nos parece racional um sistema de determinação da pena que, embora parta de considerações preventivo-gerais, relegando a medida da culpa a um papel secundário, possa, para evitar conflitos resultantes da exigência de se atender ao abalo causado à comunidade com a necessária medida da culpa, novamente recorrer àquela culpa inicialmente relegada a segundo plano — para, mais uma vez, transformá-la em principal fator limitador da pena. Ou bem se parte da culpa como limite máximo instransponível e, a partir daí, são tomadas em conta finalidades preventivas como forma de individualização da pena, ou bem se abandona a medida da culpa para privilegiar outras finalidades no processo de medição da sanção.

O modelo de moldura de pena de Anabela Miranda (que acompanha o pensamento de Figueiredo Dias ${ }^{319}$ ) nos parece demasiadamente criticável e inconsistente quando se pensa que, na determinação da medida da pena, os fatores de prevenção geral já foram

${ }^{317}$ Idem, ibidem, p. 574.

${ }^{318}$ Idem, ibidem, loc. cit..

319 Também para Figueiredo Dias, a culpa fornece apenas um limite máximo de pena que não pode ser ultrapassado; a medida da pena vem antes a ser determinada em último termo por considerações de prevenção, sendo por essa via que se torna também possível (e necessário) dar relevo a muitos fatores relacionados com o tipo de ilícito. O autor também refuta a tese de que na culpa para efeito de medida da pena tenham que ser expurgados todos os fatores relacionados com a personalidade do agente, os quais só poderiam relevar para a medida da pena pela via da prevenção. Para ele, "é referindo a culpa à personalidade do agente - através da 'atitude pessoal' manifestada no fato e que o fundamenta - que o conceito se torna do mesmo passo prestável e necessário para as tarefas de medição da pena”. Igualmente nesse ponto, também discordamos do referido autor. DIAS, Jorge de Figueiredo, Op. cit., p. 220. 
considerados pelo próprio legislador ao estabelecer o marco penal abstrato e, portanto, apenas devem ser consideradas finalidades retributivas (da culpa) e/ou preventivas especiais, como forma de se alcançar um mínimo de racionalidade no processo de individualização judicial da pena. Afinal, a pena não se aplica à comunidade abalada pela gravidade do fato (ou pelo menos, não primordialmente a ela), mas ao autor do delito, que é exatamente quem sofrerá a restrição de sua liberdade individual.

Ao pretender o processo inverso, submete-se o agente a um verdadeiro processo de instrumentalização em prol de objetivos de política-criminal não relacionados diretamente com o fato por ele praticado.

\subsection{Critérios e princípios na graduação da pena}

Conforme já se apresentou inicialmente, no nosso sistema penal falta ao julgador um direcionamento racional no que diz respeito à determinação judicial da medida da pena. Ademais, faltam uma clara referência legal e um desenvolvimento teórico consistente a respeito dos critérios que devem ser considerados no momento da determinação da medida da pena. Mas, mais do que isso, falta uma orientação clara a respeito de quais elementos relacionados ao fato possuem relevância para a valoração daqueles critérios para que, então, o julgador possa dar a essa medida um correspondente quantitativo e qualitativo de pena.

Acima de tudo isso, é fundamental, ainda, que se assuma em nosso sistema jurídico-penal, definitivamente, o princípio da culpabilidade pelo fato, deixando-se de lado qualquer resquício de uma culpabilidade de autor em quaisquer de suas versões.

Mesmo as vertentes mais moderadas de uma culpabilidade de autor, ainda presentes em nossa doutrina, não têm como seguir insistindo em um conceito de culpabilidade ultrapassado e claramente ligado àquelas ideias subjetivistas que permearam nossa legislação e doutrina jurídico-penal de elementos relacionados à intimidade do agente, “cegando”, da mesma forma, a correta análise da culpabilidade. 
E, para que isso seja possível, as próprias circunstâncias judiciais de determinação da pena, prescritas na lei penal, merecem ser questionadas e, até onde for possível, reinterpretadas sob um ponto de vista distinto.

A proposta que ora se passará a expor carece de um desenvolvimento ulterior mais profundo. Tanto porque em nossa doutrina ainda predomina o que Tatjana Hörnle irá chamar de "concepção antiquada da culpabilidade" ou “conceito personalizado de culpabilidade" ${ }^{320}$, quanto em razão da insistência de nossa jurisprudência em dar relevo à subjetividade do agente e a um equivocado — e indevido — relacionamento dela com o conceito de culpabilidade para a medida da pena.

Portanto, a pretensão deste trabalho é, por ora, colocar o problema e apresentar possíveis alternativas à mudança que se pretende e se impõe como necessária.

\subsubsection{Culpabilidade e gravidade do injusto ${ }^{321}$}

Uma concepção moderna da culpabilidade deve ser entendida como "um processo de atribuição normativa do fato ao seu autor”, constituindo, assim, um juízo de imputação que é pressuposto da pena. Assim entendida a culpabilidade, é forçoso concluir que ela carece de funcionalidade direta para obrar como parâmetro de quantificação da sanção ${ }^{322}$.

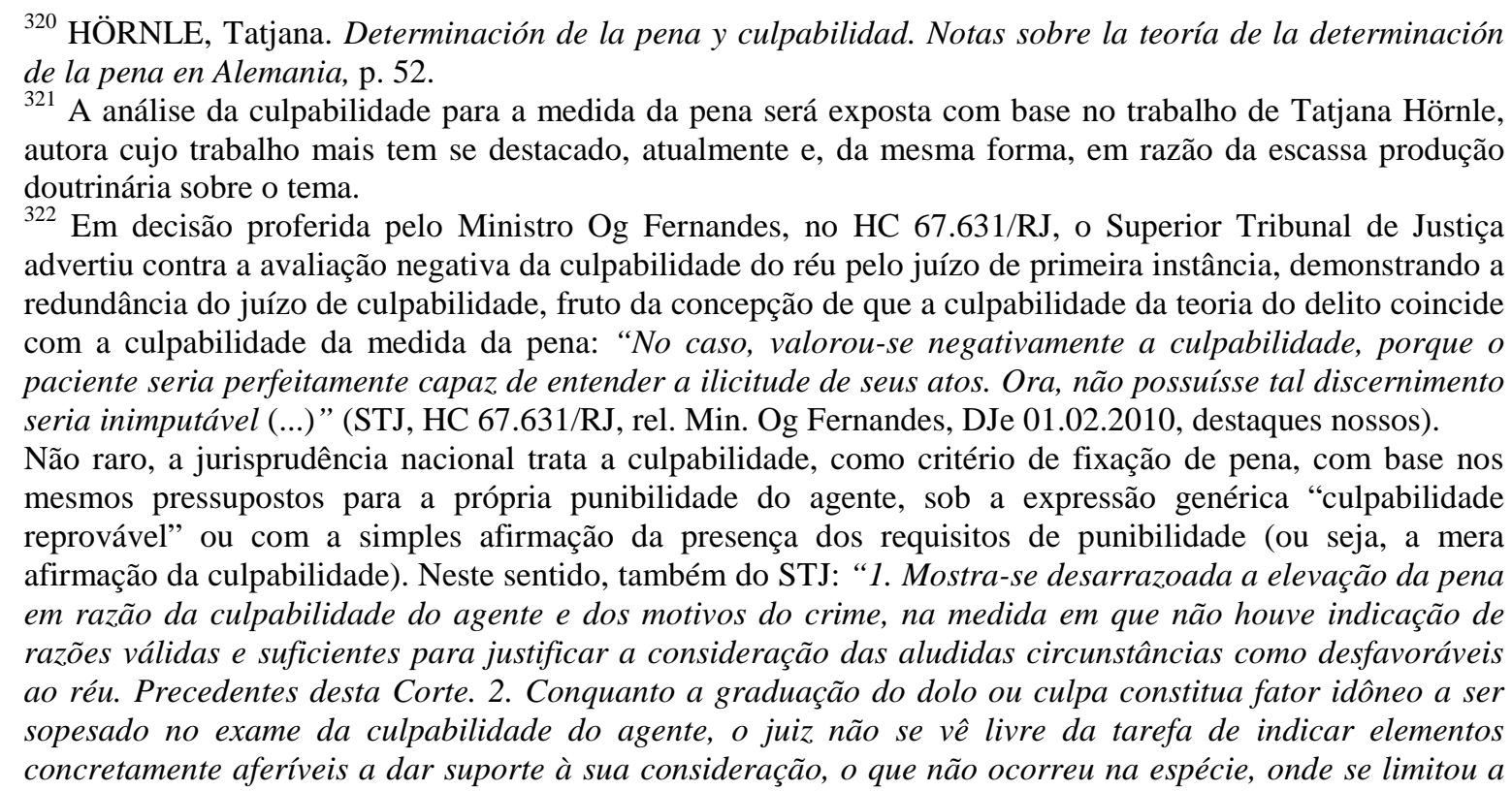


Martín Besio Hernández clarifica essa ideia nos seguintes termos:

\begin{abstract}
"Em definitivo, a culpabilidade careceria de gravidade que possa servir para sua transformação em medida de pena, pois toda a gravidade do delito se encontra no injusto penal que é atribuído - mediante o juízo de culpabilidade — a seu autor e, nessa tarefa, garantirá sua plena atribuição, sua atribuição parcial ou impediria sua atribuição” ${ }^{323}$.
\end{abstract}

Portanto, afirma-se que a culpabilidade constitui um pressuposto da pena, mas não é “suscetível de erigir-se a um critério de medição da sanção” ${ }^{324}$. Daí a afirmação de que "a culpabilidade é só uma peneira pela qual tem que passar em seu caminho à medida da culpabilidade, o quantum - único relevante — do injusto” ${ }^{325}$.

Tatjana Hörnle afirma que, no momento de concretizar o conteúdo semântico da culpabilidade (conforme determina o $\$ 46,1^{\circ}, \mathrm{I}, \mathrm{StGb}$ ), é necessária a adesão a uma valoração retrospectiva do fato como fundamento da medição da pena e, acima de tudo, que o ponto de partida da determinação da pena não esteja determinado por considerações preventivas. Aliás, a autora refere que a valoração retrospectiva do fato poderia ter sido formulada pelo legislador de outra maneira, por exemplo, mediante uma referência à gravidade do fato ${ }^{326}$.

Dessa maneira, não se pode entender a culpabilidade como uma referência direta exclusiva à categoria culpabilidade no sentido do sistema do delito. A chamada culpabilidade na medição da pena não é idêntica à culpabilidade como fundamento da pena: “a pena adequada à culpabilidade tem que orientar-se à gravidade do fato e ao grau de culpabilidade pessoal do autor" ${ }^{327}$.

ressaltar, de forma genérica, ser o réu possuidor de potencial consciência da ilicitude" (STJ, HC 104.686/MG, rel. Min. Laurita Vaz, DJe 15.06.2009, destaques nossos). Ainda: "O conhecimento da ilicitude do fato é pressuposto da culpabilidade, não servindo para exasperar a reprimenda na primeira fase da dosimetria da pena". (STJ, HC 84.179/MS, rel. Min. Maria Thereza de Assis Moura, DJe 24.05.2010, destaques nossos).

${ }^{323}$ HENÁNDEZ, Martín Besio. Los criterios legales y judiciales de individualización de la pena, p. 248.

${ }^{324}$ Idem, ibidem, passim.

${ }^{325}$ HORN, Apud HERNÁNDEZ, Martín Besio. Ibidem, p. 248.

${ }^{326}$ HÖRNLE, Tatjana. Op. cit., p. 46.

${ }^{327}$ Idem, ibidem, p. 48-49. 
Na doutrina brasileira encontramos, de forma semelhante, o pensamento de Juarez Tavarez. Para ele, que se afasta, em parte, da teoria proposta por aqueles que pretendem dissociar os momentos da culpabilidade (como pressuposto e como limite da pena), tal qual Von Hirsch - que separa os momentos de afirmação da culpabilidade e de imposição da pena - o correto seria produzir-se uma firme associação entre esses elementos ${ }^{328}$.

Para o processo de dosimetria da pena, Juarez Tavarez propõe que o juízo da culpabilidade não deva ser entendido de um ponto de vista positivo, mas sim, como um juízo negativo de capacidade de motivação. E esse processo deve ser dar sempre por um viés jurídico, e não moral.

Como o juízo de culpabilidade, para o autor, é uma etapa protetiva do autor contra o arbítrio do Estado, o conteúdo da culpabilidade não pode ser composto, exclusivamente, de elementos abstratos que conduzam a um puro juízo hipotético de poder atuar de outro modo. Deve estar constituído de elementos que sejam capazes de refutação

\footnotetext{
“(...) e isso só será possível quando se mesclem nesses elementos características objetivas, apreensíveis não apenas por juízos aléticos, mas também por referências normativas, capazes de revestir o empírico de uma roupagem adequada a uma ordem jurídica assentada na defesa da pessoa e de seus direitos” 329 .
}

O meio para isso seria referir a culpabilidade ao desvalor do fato e ao desvalor do resultado, o que implicaria em obedecer fielmente ao princípio da proporcionalidade entre fato e pena. Dessa forma - à semelhança da ideia de Hörnle - a culpabilidade seria medida conforme elementos do próprio injusto em função do agente ${ }^{330}$.

Ademais, a avaliação da culpabilidade pela gravidade do fato, segundo o autor, deve pautar-se na concretização do resultado de lesão ou de perigo de lesão:

\footnotetext{
${ }^{328}$ TAVAREZ, Juarez. Culpabilidade e individualização da pena, p. 128.

${ }^{329}$ Idem, ibidem, p. 134.

${ }^{330}$ Idem, ibidem, p. 135.
} 
“Uma vez assentada a relação entre culpabilidade e lesão de bem jurídico, podese admitir que esse critério atende, de certo modo, ao princípio da proporcionalidade e limita a intervenção penal do Estado. Ao exigir-se que a pena não possa ser desproporcional ao injusto realizado, evita-se, assim, que, por lesões insignificantes, autores reincidentes sejam reprimidos mais rigorosamente tão somente em face de sua condição especial” ${ }^{331}$.

Além desse critério, o autor defende que a autonomia do autor para realização do fato também deve servir para a avaliação da culpabilidade com o fato concreto ${ }^{332}$.

Em conclusão, a individualização da pena-base se daria em conformidade com o grau de autonomia do sujeito e a dosagem da gravidade pelo resultado de lesão ou perigo de lesão ao bem jurídico. Contudo, ressalta que, para a aferição da gravidade do injusto, há que se enfrentar certa dificuldade, na medida em que se trata de avaliar objetivamente a lesão ou perigo de lesão de bem jurídico no contexto da autonomia do sujeito.

Em primeiro lugar, recomenda que se separe definitivamente lesão ao bem jurídico das consequências pessoais ou sociais do crime:

\footnotetext{
“Essa precisa identificação da qualidade da lesão, traduzida em lesão de bem jurídico, e não em lesão de interesses sociais genéricos, é uma consequência necessária do princípio de legalidade, que só pode admitir uma criminalização quando a conduta vedada possa ser perfeitamente identificada tanto no processo de seu desenvolvimento quanto no resultado vinculado ao respectivo tipo de delito" 333 .
}

Conclui, assim que, “com base nesses fatores objetivos, conjugados com aqueles relacionados à autonomia do autor, pode-se obter uma aproximação do grau de culpabilidade e se determinar a fixação do limite máximo da pena” ${ }^{334}$.

\footnotetext{
${ }^{331}$ Idem, ibidem, p. 139.

332 No que se refere à autonomia do sujeito para avaliação da culpabilidade, o autor refere que deverão ser considerados elementos do contexto individual e social que tenham limitado sua autonomia. "Se ao sujeito fosse absolutamente fácil seguir sua vida normal, sem realizar o fato, poder-se-ia concluir que sua culpabilidade não é diminuta”. Ibidem, p. 143.

${ }^{333}$ Idem, ibidem, p. 416.

${ }^{334}$ Idem, ibidem, p. 147.
} 
O autor brasileiro ressalta, entretanto, que todos esses fatores devem influir tão somente na dosimetria da culpabilidade se, efetivamente, houverem influenciado a constituição do injusto, evitando que idiossincrasias ou impressões subjetivas do julgador influam na apreciação da culpabilidade.

A questão fundamental passa a ser a de selecionar quais critérios devem ser valorados para a graduação do injusto de resultado e do injusto de ação. Para Hörnle, isso ainda depende de um desenvolvimento teórico ulterior:

\begin{abstract}
"Tarefa essencial de um Direito moderno de medição da pena é o ulterior desenvolvimento e pontualização deste dado. Devem se desenvolver critérios para averiguar a medida do injusto de resultado e quais facetas da conduta do autor influem no injusto de ação. Especialmente neste último ponto contem uma grande quantidade de questões concretas problemáticas, cuja clarificação é indispensável para standards precisos de medição de pena. Até agora, no Direito de medição da pena não se discutiu com precisão sobre quais fatores que conformam a extensão do injusto de ação. Precisamente por isso, existe o perigo de que se faça passar, de forma irreflexiva ou decorativa, considerações preventivas como valorações do injusto”,335
\end{abstract}

As teorias "antigas” da culpabilidade, diferentemente da moderna teoria do delito, faziam incidir a reprovação da culpabilidade por meio de critérios próprios ${ }^{336}$. Como já se referiram inicialmente, as principais teorias sobre a culpabilidade desenvolvidas nas primeiras décadas do século XX tinham como característica a concepção — denominada por Hörnle de "caracterológicas" — de que a medida da culpabilidade só pode ser constatada em cada caso se se conhece a atitude interna individual do autor.

Trata-se das versões de culpabilidade pela conduta de vida ou da atitude interior que "se desprendem completamente de uma valoração do fato" e que influíram sensivelmente a compreensão da culpabilidade na época ${ }^{337}$.

\footnotetext{
${ }^{335}$ HÖRNLE, Tatjana. Op. cit., p. 50. O alerta da autora é o mesmo no que se refere à culpabilidade pessoal do autor do fato, já que "a valoração não só se determina pelo resultado do fato e as circunstâncias concomitantes que conformam o injusto de ação, senão também e de maneira essencial, pelo conteúdo semântico e a importância que se atribua à 'culpabilidade pessoal do autor'”. Trad. livre. Idem, p. 51.

${ }^{336}$ Sobre um desvio de conduta pessoal ou uma atitude interna defeituosa do agente.

${ }^{337}$ Cf. HÖRLE, Tatjana. Ibidem, p.56.
} 
Explica Víctor Gómez Martin que, para as concepções sintomáticas do delito, o fato delitivo não deve ser desvalorado por sua repercussão no mundo exterior, senão porque revela que seu autor representa uma personalidade desviada. O fato é tão somente um sintoma da culpabilidade de seu autor, em seu sentido de "vontade antissocial” ou “antissociabilidade”. A preocupação com a personalidade do autor constituiu, em suma, a essência das concepções sintomáticas do delito ${ }^{338}$.

O fato delitivo expressaria o caráter ou a personalidade do delinquente e a culpabilidade do autor consistiria na responsabilidade pelo caráter, de modo que a perigosidade do delinquente, condicionada por sua personalidade, se apresentaria aos olhos dessa concepção como um elemento da culpabilidade.

Tendo em vista que a punibilidade deveria ter como pressuposto o fato, mas, de outro lado, o fato mesmo seria expressão da personalidade do autor e que esta representaria propriamente o objeto mesmo da culpabilidade, a esta última circunstância dever-se-ia reconhecer alguma relevância. Segundo Von Liszt e a concepção sintomática do delito, a concepção caracterológica da culpabilidade também considerou que a sede mais adequada para dar-se tal relevância seria a da determinação da pena ${ }^{339}$.

Na esteira do que vimos dito desde os primeiros capítulos, é importante observar a afirmação de Víctor Gómez no sentido de que a direção sintomatológica, encontrada nas teorias de Tesar e Kollmann

“(...) deve ser contemplada como uma consequência circunscrita a uma época
dominada pelo auge do positivismo empírico que influenciou decisivamente em
todas as disciplinas que integravam a criminologia em sentido amplo, entre as
que se encontrava a Psicologia Criminal. (...) Deve reconhecer-se que a
concepção que agora nos ocupa tomou como ponto de partida uma ideia que,
desde o ponto de vista da Psicologia Criminal, dificilmente pode ser objeto de

${ }^{338}$ MARTIN, Víctor Gómez. El derecho penal del autor, p. 103. Ainda de acordo com o autor, na Alemanha, os dois principais representantes da concepção sintomática do delito são discípulos de Von Liszt: Tesar e Kollman. Além deles, Radbruch representou a linha de pensamento representada pela chamada "concepção caracterológica da culpabilidade”.

${ }^{339}$ Idem, ibidem, p. 110. 
discussão: o delito constitui um sintoma, é revelador da personalidade do sujeito que o comete" ${ }^{340}$.

No entanto, na atualidade, a opção por quaisquer dessas vertentes não tem como fundamentar a necessidade ou o merecimento da pena. Seja a partir de um conceito causal ou realístico, seja a partir de um ponto de vista sintomatológico ou a partir de um conceito misto que combine ambos os fundamentos. Nas palavras daquele autor, "frente a todos estes fundamentos se considera preferível optar por um que contemple o delito como um comportamento que lesiona ou põe em perigo interesses sociais sem os quais seria impossível o correto funcionamento social” ${ }^{341}$.

Isso porque tal entendimento da culpabilidade vai de encontro com o pensamento do crime como "sintoma" de uma personalidade defeituosa que se expressa no fato criminoso (ou que se deve evitar, antes mesmo que o agente cometa o crime). É o que Hörnle denomina de concepção “personalizada da culpabilidade” ${ }^{342}$.

Em definitivo, trata-se de uma concepção de culpabilidade que se vale da personalidade do agente e de outros critérios subjetivos (como os antecedentes e a conduta do agente após o delito) para dar-lhe a exata medida. Uma verdadeira herança do positivismo criminológico o século XX. Nas palavras de Bettiol:

"Foram as tendências subjetivistas e a concepção ética do direito penal que permitiram vislumbrar a psique do sujeito ativo para individuar a forma de

\footnotetext{
${ }^{340}$ Idem, ibidem, loc. cit..

${ }^{341}$ Idem, ibidem, p. 111.

${ }^{342}$ Parece-nos desnecessário discorrer longamente a respeito da concepção da culpabilidade como expressão da personalidade do agente, uma vez que essa tem sido a vertente mais comumente adotada por nossa doutrina nacional. A título de exemplo e para fins de conceituação, vale destacar o entendimento do penalista italiano Giuseppe Bettiol, que adotou o que se pode chamar de uma posição "moderada" ou "existencialista" da concepção antiquada da culpabilidade. Bettiol afirma que, na "culpa de autor", não se pretende castigar a pessoa como é, seu modo de ser sobre o qual não tem controle ou possibilidade de resistir. Esse, afirma, seria o campo da periculosidade e não da culpabilidade. Defende que, na esfera da culpabilidade, pune-se aquela inclinação à qual o sujeito imprimiu livremente determinado rumo à própria vida: "Foi elucidado por Mezger que uma culpa pela conduta de vida pode subsistir tão-só enquanto estiver no 'poder do agente' assumir o seu particular modo de ser, devendo-se realmente distinguir no âmbito da personalidade empírica diversos componentes, tais sejam aqueles que podem ser superados pelo sujeito e aqueles aos quais o próprio sujeito se submete”. BETTIOL, Giuseppe. Direito Penal, p. 25.
} 
culpabilidade que até então escapara aos juristas, ao passo que em seu derredor já existia rica literatura dos moralistas” ${ }^{343}$.

A medida da culpabilidade, segundo a vertente da culpabilidade pela condução de vida, dá-se por meio da censura não apenas do ato praticado pelo agente, "mas a todas as ações precedentes que determinaram uma inclinação no ânimo do réu” ${ }^{344}$.

Até hoje, afirma Hörnle, a teoria majoritária da medição da pena não questionou o papel dominante da personalidade do autor: “(...) nela prevalecem exposições que partem de um componente 'caracterológico do conceito de culpabilidade' e que consideram os fatores pessoais como relevantes para a medida de culpabilidade na medição da pena” ${ }^{345}$.

O fator preocupante na insistência de uma concepção da culpabilidade assim delimitada é que uma censura orientada ao caráter ou à atitude interna admite um aumento de pena ilimitado, que não guarda proporção com a gravidade do fato ou com qualquer outro critério relacionado ao injusto:

\footnotetext{
"Se a censura da culpabilidade se baseia em um modelo de diferença, que indaga se as atitudes internas se afastam de um tipo ideal - como quer que se determine — isto implica a possibilidade ilimitada de quantificar essa diferença. O desvio é graduável em ambas as direções, até para baixo até a ausência de culpabilidade passando pelo estado da culpabilidade diminuída; mas sobretudo, não se estabelece nenhum limite para cima à reprovabilidade da atitude interna” ${ }^{346}$.
}

Ainda segundo Hörnle, o Tribunal Federal de Justiça da Alemanha (BGH), em uma jurisprudência constante, parte da ideia de que para a medição da pena é indispensável a

\footnotetext{
${ }^{343}$ BETTIOL, Giuseppe. Direito Penal, p. 23.

${ }^{344}$ Idem, ibidem, loc. cit. Ainda segundo Bettiol, a reincidência justifica também o agravamento da pena exatamente porque “(...) se reprova no agente todo um teor de vida determinado, toda uma repetição de ações delituosas que lhe deixaram como que um sulco doloroso de inclinação ao crime". E, ainda, "É esta quem, através da pena agravada, deve ser 'purgada'. Se a pena pressupõe a culpabilidade, uma pena que supere as exigências de expiação de uma ação delituosa singular só pode ter presente um tipo de culpabilidade que ultrapasse a ação individualmente considerada. A reprovação atém-se a toda a personalidade" (Ibidem, p. 24).

${ }^{345}$ HÖRLE, Tatjana. Trad. livre. Op. cit., p. 56.

${ }^{346}$ Trad. livre. Idem, ibidem, p. 57.
} 
apreciação das circunstâncias pessoais do autor, mas não apenas para assegurar as considerações preventivo-especiais, "mas para constatar a culpabilidade pessoal”347.

Segundo a autora, na teoria dominante da medição da pena e na jurisprudência não fica claro por que as circunstâncias pessoais do autor devem ser relevantes para a culpabilidade:

\begin{abstract}
"Tal base teórica só existiria nas teorias da culpabilidade pelo caráter ou pela condução de vida, difundidas à época nacional socialista e nos primeiros anos do pós-guerra (...) As teses particulares de cada autor se distinguem, entre outras coisas, no que atine com a culpabilidade (Verschulden) do sujeito pela formação de seu caráter ou de sua personalidade. Alguns exigem do autor 'fazer-se responsável pelo que é, sem ter em conta por que múltiplas causas se converteram no que é'. Outras teses, no entanto, constroem uma culpabilidade do sujeito pela evolução de sua personalidade e de sua posição vital, ainda que por isso o requisito da culpabilidade se maneja em parte formalmente, enquanto que o poder ser de outro modo se contempla como uma função estatal necessária”,348.
\end{abstract}

Já a jurisprudência alemã moderna, afirma a autora, se distancia das teorias da culpabilidade pelo caráter ou pela condução de vida e os próprios tribunais de primeira instância são criticados em modernas decisões da jurisprudência dos Tribunais Superiores, quando apelam à condução de vida do autor como fator de medição da pena:

\begin{abstract}
“Tampouco na literatura contemporânea se pode encontrar já defensores das teorias da culpabilidade pelo caráter ou pela condução de vida. Com isso falta uma conexão consistente entre uma concepção personalizada da culpabilidade e uma teoria útil como tese explicativa” ${ }^{349}$.
\end{abstract}

É importante que se deixe claro que a consideração das circunstâncias pessoais do agente não deve ser rejeitada de modo absoluto. De fato, conforme se verá mais adiante,

\footnotetext{
${ }^{347}$ Na jurisprudência brasileira, tal proceder chega a ser a regra que, em raras vezes, comporta alguma exceção.

${ }_{348}^{34 d e m, ~ i b i d e m, ~ p . ~} 60$.

${ }^{349}$ Idem, ibidem, p. 61. Não obstante, a autora lamenta que mesmo com o abandono das teorias da culpabilidade pelo caráter e pela condução de vida, não se tenham extraído conclusões sobre a concepção da culpabilidade na medição da pena. Chama a atenção a ela o vetusto estado da teoria da medição da pena quando, apesar de uma tomada de posição crítica a respeito do conceito de culpabilidade orientado à atitude interna, na medição da pena volte-se a colher, sem mais, a valoração da atitude interna do autor.
} 
elas são relevantes sob um ponto de vista de prevenção especial positiva (mas, advirta-se: não quando atreladas à análise da própria culpabilidade) — sobretudo quando se trata de evitar a dessocialização do agente ${ }^{350}$.

O que se pode concluir desse modelo de orientação é que o conceito de culpabilidade para a medida da pena, segundo a concepção moderna de culpabilidade, pouco importa para a individualização judicial da sanção. Ao se partir da valoração do injusto (e sua gravidade mensurável), numa perspectiva retroativa ao fato, a culpabilidade acaba se vendo reduzida a sinônimo da gravidade do fato ou da gravidade do injusto culpável $^{351}$. Assim postas as coisas, fica assegurado o princípio da culpabilidade pelo fato.

Segundo as conclusões da autora, o exame da culpabilidade deve assemelhar-se a um “filtro" ${ }^{352}$. Em casos normais, ausentes causas que diminuam a culpabilidade, o peso do fato se determinada exclusivamente pelo injusto do fato. Ao contrário, se a culpabilidade estiver diminuída, nem todo o peso do injusto chega a ser eficaz para a medição da pena. E, ao contrário, uma elevação da pena como consequência do exame de culpabilidade estará excluída, porque não há circunstâncias que incrementem a culpabilidade $^{353}$.

O autor espanhol Demetrio Crespo chega a conclusões semelhantes no que toca aos critérios de determinação da pena, segundo as prescrições do Código Penal espanhol ${ }^{354}$.

\footnotetext{
${ }^{350}$ A autora, nesse ponto, admite também a consideração das circunstâncias pessoais do agente em sede de culpabilidade quando sejam capazes de reduzir a pena por razões que, embora não constituam causas excludentes de culpabilidade, possam ser consideradas análogas àquelas e tenham influído negativamente na capacidade de compreender e comportar-se perante o fato, como por exemplo, no caso de uma situação de necessidade econômica do autor. Dessa forma, a autora admite que as circunstâncias pessoais possam ser relevantes para a medida da pena, mas não sob uma perspectiva atrelada à concepção personalizada da culpabilidade. Ibidem, p. 63.

351 À expressão "pena adequada à culpabilidade" a autora prefere a substituição pela expressão "pena adequada ao injusto e à culpabilidade”. Ibidem, p. 70.

${ }^{352}$ A autora utiliza a expressão de Horn.

353 Idem, ibidem, p. 68. Não é possível, em especial, admitir o incremento da medida da pena sob o fundamento da culpabilidade elevada por razões referidas à personalidade do autor. "É difícil fundamentar que no último estágio da imposição de normas jurídico-penais deva ter lugar um deslocamento do peso destas formas de comportamento externo a uma valoração introspectiva da personalidade do autor". Ibidem, p. 69.

354 O Código Penal espanhol (art. 66, 6º indica que a aplicação da pena quando não concorram circunstâncias agravantes ou atenuantes deverá ser determinada, considerando-se as "circunstâncias pessoais" do delinquente e "a maior ou menor gravidade do fato".
} 
Conforme o modelo espanhol atual deveria estar já superada, em razão da disposição da própria lei penal, a discussão a respeito do papel da culpabilidade na determinação da pena, porquanto os critérios a serem aferidos pelo juiz limitam-se às “circunstâncias pessoais do réu” e à “maior ou menor gravidade do fato”355.

No que toca à mensuração da gravidade do injusto, Crespo parte, como premissa principal, da necessidade de determinação do fim da pena. A partir desse ponto é que passam a ser valorados os fatores reais a se ter em conta na individualização da sanção ${ }^{356}$.

O autor deixa claro que uma interpretação do processo de individualização judicial da pena que se guie e fundamente no critério da gravidade do fato, interpretado sob o ponto de vista da retribuição da culpa não é compatível com a regulação dos Códigos Penais alemão e espanhol:

\begin{abstract}
“(...) os critérios para a interpretação da reprovabilidade do fato, com o correspondente aumento ou diminuição da culpabilidade, já foram selecionados pelo legislador no nosso ordenamento jurídico em um amplo catálogo de circunstâncias atenuantes e agravantes, que jogam como catálogo incompleto de fatores reais da individualização judicial da pena previstos legalmente” 357 .
\end{abstract}

Já sob uma perspectiva preventivo-geral, aduz que o critério da gravidade do fato na individualização judicial da pena possui um papel tanto de limite à prevenção geral

\footnotetext{
${ }^{355}$ Nesse ponto, o código espanhol parece mais avançado no sentido de uma racionalidade na determinação da pena, já que o critério da culpabilidade já está “substituído” pelo da "gravidade do fato”, o que autoriza o autor a elaborar a seguinte crítica: "A afirmação relativa a que a medida da culpabilidade pelo fato depende do conteúdo de injusto do fato penal individual e de que a quantidade de pena adequada ao injusto se mede de acordo à gravidade do injusto individual parece clara. No entanto, por si mesma, não passa de uma mera declaração de princípios”. DEMETRIO CRESPO, Eduardo. Análisis de los criterios de la individualización judicial de la pena en el nuevo código penal español de 1995, p. 332.

Não obstante, Martín Besio pondera que a forma de levar a cabo a operação de individualização da pena segundo o modelo espanhol está longe de ser unívoca e que na individualização da pena é generalizado o entendimento segundo o qual o juiz deve estabelecer a medida da pena que seja proporcional ao desvalor do injusto concretamente executado pelo autor e adequada à culpabilidade. Op. cit., p. 297.

356 “Na medida em que o legislador não informa se a gravidade do fato deverá medir-se conforme o fim da pena de retribuição, ou de prevenção geral ou especial, um mesmo fato haverá de ser medido de forma diferente segundo se entenda que dita medição serve à retribuição da culpabilidade, à produção de confiança nos cidadãos sobre o ordenamento jurídico ou à prevenção da reincidência” DEMETRIO CRESPO, Eduardo. Op. cit., p. 334.

${ }^{357}$ Idem, ibidem, p. 337.
} 
como também é um fim do Direito Penal e da pena, além de um limite à própria individualização judicial da pena derivado do Estado de Direito ${ }^{358}$. Em conclusão:

\begin{abstract}
“A gravidade do fato deveria considerar-se como limite máximo da quantia da pena, o qual constitui, a meu modo de ver, uma garantia para o indivíduo que se deriva do princípio de culpabilidade como princípio constitucional derivado do Estado de Direito, que não pode ser excedido em nenhum caso, nem por razões de prevenção geral, nem por razões de prevenção especial, e que coincide basicamente com as exigências da "culpabilidade pelo fato" ${ }^{359}$.
\end{abstract}

Diante do que ora se expôs — porém longe de se assumir um posicionamento definitivo a respeito dos fins da pena no Direito Penal brasileiro para fins de determinação da sanção penal — resta concluir que uma racionalização do processo de individualização da pena não depende, apenas, da elaboração de critérios claros relacionados com o injusto do fato, mas também da uma mudança na concepção da culpabilidade e do seu papel na determinação da pena. É forçoso concluir que uma culpabilidade da atitude interior ou pela condução de vida é incompatível com a moderna teoria do delito, além de macular de inconstitucionalidade o processo de individualização da pena.

A ênfase desse processo de fundamental importância para o acusado há de se voltar para a gravidade do fato, seja sob qual finalidade da pena se o entenda. Não obstante, os fatores reais da aferição da gravidade do injusto a partir do fato praticado (de ação e de resultado) é outra questão a se desenvolver, que ultrapassaria os limites deste trabalho.

\title{
3.3.2. Critérios subjetivos
}

Com essas bases, cumpre discutir o papel que os critérios subjetivos devem exercer para a determinação da medida da pena.

\footnotetext{
${ }^{358}$ Crespo rechaça a finalidade preventiva geral como fator final da individualização judicial da pena (o que não significa negar essa função à pena, pelo contrário: a imposição da pena pelo juiz confirma dita função). $\mathrm{O}$ que importa para ele são as consequências dogmáticas de uma interpretação preventiva geral do fator real "gravidade do fato" e essas não são outras que a admissão do critério interpretativo do "perigo de difusão do delito" ou da "real difusão do delito". Esses critérios constituem a desculpa para satisfazer necessidades preventivo gerais (normalmente ao abrigo da culpabilidade). Idem, ibidem, p. 340.

${ }^{359}$ Idem, ibidem, loc. cit..
} 
Muito embora o presente trabalho esteja voltado ao critério subjetivo “personalidade do agente”, algumas considerações podem ser feitas, de maneira geral, a respeito de outros elementos relacionados à intimidade do autor que igualmente se inserem na categoria de critérios subjetivos relevantes para a determinação final da pena e que são objeto de profundos questionamentos, especialmente na doutrina espanhola.

\subsubsection{O papel dos critérios subjetivos na determinação da pena e sua ligação com o fim de prevenção especial positiva}

De acordo com Martín Besio Hernández, em todos os modelos dogmáticos espanhóis a prevenção especial é um fim do Direito Penal que incide na individualização da pena e, portanto, constitui fator final de medição da sanção. Segundo afirma, em todos esses modelos verifica-se a exigência de proporcionalidade entre a pena e a gravidade do fato, imposição que é erigida a critério limitador de exigências de corte preventivo que pretendam impor uma quantia de pena superior ao limite máximo marcado pela proporcionalidade com a gravidade do fato ${ }^{360}$.

De outro lado, também se aceita que, no momento de quantificação da pena específica a impor, sua magnitude pode ser reduzida abaixo do limite mínimo demarcado e exigido pelo parâmetro da proporcionalidade com a gravidade do fato, em função da adequação desta aos critérios político-criminais de prevenção especial. Por fim, sustentase majoritariamente que a proporcionalidade com a gravidade do fato impõe um limite máximo aos interesses de prevenção especial. Assim, entre esse intervalo de pena são os critérios de prevenção especial, ou seja, aqueles critérios de caráter subjetivo relacionados ao agente, que irão decidir, quase que exclusivamente, a quantia concreta de sanção ${ }^{361}$.

A prevenção especial, ainda segundo Martín Hernández, atualmente é majoritariamente entendida sob o ponto de vista do intento de evitar que o indivíduo que já tenha cometido um delito volte a fazê-lo, isto é, assume o objetivo específico de evitar a

\footnotetext{
${ }^{360}$ Op. cit., p. 135.

${ }^{361}$ Idem, ibidem, loc. cit..
} 
reincidência. Opera, portanto, não sobre a comunidade, senão sobre o individuo que haja delinquido ${ }^{362}$.

No entanto, em sua versão original, sobretudo a preconizada pelo pensamento de Von Lizst, a prevenção especial importa diferentes conteúdos associados cada um deles à diferente categoria de individuo concreto objeto da sanção criminal: intimidação individual, ressocialização e inocuização. Como bem identifica aquele autor, não há como se refutar que atualmente os aspectos que integrariam a parte negativa da tarefa preventivoespecial (intimidação e inocuização) parecem haver perdido na dogmática uma função lícita específica desse fim da pena, existindo um certo consenso em se atribuir à prevenção especial uma tarefa única positiva de ressocialização ${ }^{363}$.

Além disso, Hernández adota um posicionamento — no qual é acompanhado por outros, dentre eles, Demétrio Crespo $^{364}$ — no sentido de que a prevenção especial na medição quantitativa da pena só pode operar entendida como pretensão de não dessocialização do delinquente em termos tais que só seja possível diminuir a quantia de pena assinalada ao delito, e nunca aumentada ${ }^{365}$.

\footnotetext{
"Entendo em definitivo que na individualização da pena as considerações de prevenção especial (incluídas na cláusula legal de circunstâncias pessoais do delinquente) admitem a valoração de todas aquelas razões que permitam ao juiz diminuir a pena assinalada ao delito com o objetivo específico de evitar na
}

\footnotetext{
${ }^{362}$ Idem, ibidem, p. 77.

${ }^{363}$ Idem, ibidem, p. 78.

364 “A pena deve individualizar-se, a meu modo de ver, seguindo para isso critérios de prevenção especial positiva favoráveis que persigam acima de tudo a maximização do fim de não dessocialização do réu, assim como a consecução das máximas cotas de ressocialização sempre que isso seja possível”. Análisis de los critérios, p. 358. Dentre as principais críticas colhidas da doutrina sobre a ressocialização por meio do encarceramento, está a afirmação no sentido de que as penas possuem, incontestavelmente, um caráter criminógeno, ou seja, exercem um papel de dessocialização do agente e levam à incitação de novos delitos. É nesse caminho que se afirma que, atualmente, a ideia ressocializadora se substitui pela pretensão de evitar, sobretudo no âmbito da individualização da pena, os efeitos dessocializadores que poderiam acarretar a imposição de uma pena privativa de liberdade. Nessa direção, ver Martín Besio Hernández, Op. cit., p. 80. Também partilha da mesma ideia Patricia Ziffer, entendendo que a prevenção especial pode constituir um argumento plausível para afastar aquelas penas que poderiam ter como consequência uma definitiva dessocialização. Permitiria, portanto, definir o montante que a pena não deve ultrapassar. ZIFFER, Patricia. Op. cit., p.51.
}

${ }^{365}$ HERNÁNDEZ, Martín Besio, p. 197. 
medida do possível a dessocialização do autor por meio da pena de prisão; ou, em seu caso, que possibilitem a não imposição da pena de prisão” ${ }^{366}$.

Essa perspectiva, afirma o autor, parece consistente com a lógica utilitarista da intervenção mínima, pois a fixação da menor pena que seja possível não redunda em uma diminuição do efeito preventivo especial negativo associado à fase de determinação da pena, porquanto os marcos assinalados em sede legislativa a cada tipo penal já conteriam a quantidade de pena que é necessária para a produção de efeitos dissuasivos:

\footnotetext{
“(...) se se admitir que as exigências preventivo-especiais associadas à evitação da comissão de novos delitos (de ressocialização, de inocuização ou de intimidação individual) possam fundar uma maior quantia de sanção, se utilizará o delinquente como um meio para a consecução de fins a ele heterônomos, dado que a justificativa da maior quantidade de pena se vincula a uma maior proteção de terceiros, isto é, de outros” ${ }^{367}$.
}

Acompanhando o excerto acima apresentado, entendemos que, uma vez assentada a premissa de que a fixação da pena deve se efetuar, primeiramente, com base na gravidade do fato, o processo de individualização da pena irá operar-se, finalmente, por meio da consideração de elementos relacionados à prevenção especial positiva, respeitando-se o limite máximo fixado pela proporcionalidade com a gravidade do fato e com vistas ao fim de não dessocialização do agente.

Para tanto, os elementos de caráter subjetivo relacionados ao autor, elencados na lei, irão adquirir um caráter funcional, de forma a justificar a diminuição da quantidade da sanção, ou a substituição da pena privativa de liberdade, sob a base de uma menor necessidade preventivo-especial da pena ${ }^{368}$.

\footnotetext{
${ }^{366}$. Idem, ibidem, p. 200.

${ }^{367}$ Idem, ibidem, p.199-200.

${ }^{368}$ Idem, ibidem, p. 205. No mesmo sentido, entre nós, o posicionamento de Juarez Tavarez:

"Uma vez reconhecida a culpabilidade em sua completude, tem-se que o injusto foi integralmente realizado e que, portanto, a pena não poderá ser superior ao que resulte da avaliação nele refutada (... ) Em qualquer caso, elementos subjetivos relacionados ao autor só podem ser invocados em seu prejuízo se tiverem influenciado, previamente, o desvalor da ação. Todos os demais fatores - como as circunstâncias contidas no artigo 59 do CP — só devem ser usados em favor do autor. Fatores morais ou outros relacionados à suposta má conduta do autor são estranhos ao processo de individualização e devem, desse modo, ficar de fora de qualquer avaliação”. Op. cit., p. 135.
} 
Elementos subjetivos elencados na lei, tal como a motivação do agente, não obstante sejam erigidos como um critério geralmente aceito tanto pela doutrina como pela jurisprudência, sua valoração (como agravante da pena), mostra-se ilícita sob a ótica de um modelo de Estado liberal que renuncia à sanção de foro interno dos indivíduos e só admite a imposição de uma pena sobre a base da conduta externa que ele executa:

\footnotetext{
"As razões pelas quais um sujeito comete um delito resultam irrelevantes para fundamentar a pena ou sua agravação em um Direito Penal garantista que não assume como função a educação dos cidadãos por meio da força” ${ }^{369}$.
}

De tudo que se expôs inicialmente a respeito dos objetivos de defesa social e da individualização da pena como meio de contenção da perigosidade do agente, por meio da análise de elementos relacionados ao autor e, sobretudo, pela análise de sua personalidade, é possível afirmar que a doutrina e a jurisprudência brasileiras tradicionalmente baseiam o juízo de necessidade de ressocialização em função de sua perigosidade, revelada no fato cometido e que deve ser analisada pelo juiz com base em elementos subjetivos a ela relacionados.

Como afirma o autor espanhol, é a partir do componente estritamente pessoal do indivíduo (p.e., sua situação profissional, familiar, intelectual, sua personalidade e vida anterior ao delito) que seria possível, segundo a prática judiciária tradicional, prognosticar um comportamento provável associado ou não à comissão de delitos, em termos tais que o resultado dessa projeção ao futuro permitiria, então, na fase de individualização judicial, determinar uma maior quantidade de pena pelo delito cometido ${ }^{370}$.

É impossível negar que a valoração preventivo-especial, assim entendida, constitui essencialmente uma valoração própria de um Direito Penal de Autor: a pretensão de estabelecimento de responsabilidade penal, não em razão do fato cometido, senão em função do que o individuo é (ou tenha feito antes do fato), a saber, em função de seu modo de ser ou da forma como tenha conduzido sua vida ${ }^{371}$.

\footnotetext{
369 HERNÁNDEZ, Martín Besio. Op. cit., p. 350.

${ }^{370}$ Idem, ibidem, p. 412.

${ }^{371}$ Na doutrina brasileira, admitindo essa espécie de valoração, encontra-se o entendimento de Guilherme de Souza Nucci, para quem: “A personalidade deve ser, sim, avaliada pelo juiz, sem necessidade de apoio pericial, pois a finalidade é a aplicação da pena e não de medida de segurança. Há que se visualizá-la em seus aspectos positivos e negativos, de acordo com o crime cometido, buscando-se na visão do direito penal
} 
A censura legal, nesse tipo de estrutura punitiva, se encerra sobre o individuo e não sobre a conduta externa que tenha executado, em contraposição à valoração inerente ao Direito Penal de fato. Por essa razão, o autor espanhol entende que é necessário assumir que a ponderação do componente individual do delinquente para os efeitos da atribuição de uma maior responsabilidade criminal (de um aumento de pena) importa diretamente em um juízo próprio de um Direito Penal de Autor ${ }^{372}$.

A imprecisão a respeito da probabilidade de voltar a delinquir é uma das principais razões para rechaçar a consideração de circunstâncias pessoais para fins de aumento da pena. É difícil, afirma o autor espanhol, adivinhar qual vai ser o comportamento de um sujeito sem conhecer - porque impossível - a infinidade de fatores exógenos que no futuro podem condicionar sua conduta ou as oportunidades que vai encontrar em sua vida ${ }^{373}$.

Nessa direção, critérios ou elementos subjetivos devem ser considerados na determinação da pena como forma de possibilitar a adequação da sanção final sempre em vista da não dessocialização do agente. Para tanto, devem referir-se mais precisamente a fatores pessoais que possam indicar a quantidade ou a forma de cumprimento de pena que seja mais adequada às suas condições econômicas, profissionais, familiares e pessoais ${ }^{374}$.

Demetrio Crespo, sempre mantendo uma visão no sentido da prevenção especial positiva, adverte sobre os efeitos perniciosos da execução de penas curtas privativas de liberdade no plano pessoal: separa o réu de sua família e de seu posto de trabalho e lhe

do fato, apenar-se o acusado mais gravemente se o que ele fez coaduna-se com característica negativa de sua personalidade, vale dizer, se o seu desvio de personalidade levou-o exatamente àquele crime”. Seu posicionamento, ao final, somente acaba por camuflar um verdadeiro Direito Penal de autor. Se contam, para a determinação da pena, elementos subjetivos relacionados ao autor no sentido que operam negativamente para reprovar mais quanto mais esses elementos se expressem no fato, então o que se está valorando (apenando) é o modo de ser e não o a conduta criminosa exteriorizada. (Tratado jurisprudencial $e$ doutrinário, p. 882).

${ }^{372}$ HERNÁNDEZ, Martín Besio. Op. cit., p. 412.

${ }^{373}$ Idem, ibidem, loc. cit..

${ }^{374}$ Importa destacar que há posicionamentos, como o de José Peralta, negando qualquer papel aos elementos de ordem subjetiva na medição da pena. Para esse autor, uma teoria da pena coerente com uma teoria liberal do delito não permite considerar relevante para a dosimetria nenhum motivo elemento subjetivo que transcenda o aspecto cognitivo. Segundo defende, se para a configuração do tipo penal a motivação do autor ou sua intimada não exerce qualquer papel, com muito mais razão não podem exercer para a mensuração da sanção. Afirma que em um Direito Penal cujo objetivo radica unicamente na proteção de bens jurídicos, a intenção do agente não deve exercer qualquer papel. (Elementos subjetivos del ilícito). 
impede durante o tempo de sua duração ocupar-se de sua família e reparar o dano causado. Ademais, implica perigo do chamado contágio criminal. Tudo isso ele também objeta com relação à pena privativa de liberdade de maior duração ${ }^{375}$.

As circunstâncias de caráter econômico, por sua vez, também são vistas por ele sob um ponto de vista preventivo especial positivo, pois penas de multa muito altas deixam o réu em situação de desamparo, o que pode, inclusive, constituir um fator criminógeno.

A respeito das circunstâncias de caráter profissional, assinala o autor que o Tribunal Supremo alemão já apontou a necessidade de considerar na individualização judicial da pena as consequências da imposição da pena para o futuro profissional do réu, sobretudo para funcionários para quem a imposição da pena implica perda definitiva de sua condição de empregado ou de soldados, que, se despedidos, perdem direito a indenização, ou ainda de outros profissionais que podem vir a ter suas licenças profissionais cassadas comprometendo seu futuro profissional ${ }^{376}$.

Também há que se considerar a sensibilidade e a suscetibilidade do autor à pena. Demetrio Crespo traz que sob tais denominações a doutrina alemã sobre a individualização judicial da pena vem aludindo há algum tempo a outro aspecto que se tem em conta sob pontos de vista preventivo especiais em relação à personalidade do delinquente, que, igual às circunstâncias de tipo familiar, profissional ou econômico não guardam conexão nem com a gravidade do injusto, nem com a culpabilidade, mas que constituem um fator real da individualização da pena especialmente importante ${ }^{377}$.

Sensibilidade à pena, segundo explana, significa que uma pessoa padece mais do que outra com a imposição da mesma sanção. Já suscetibilidade à pena implica que o efeito positivo ou negativo da mesma pena pode ser distinto segundo o réu, entendendo que o primeiro aspecto relaciona-se à imposição da pena mais justa no caso concreto, e o

\footnotetext{
${ }^{375}$ DEMETRIO CRESPO, Eduardo. Análisis de los criterios de la individuación judicial de la pena en el nuevo código penal español de 1995, p. 354.

${ }^{376}$ Idem, ibidem, p. 355.

${ }^{377}$ Ibidem, p. 355.
} 
segundo àquela que é necessária para demover o autor da comissão de novos delitos futuros ${ }^{378}$.

\begin{abstract}
"O elemento de sensibilidade à pena joga com o caráter atenuatório da individualização da pena e tem sido considerado na jurisprudência alemã com relação a casos de idade avançada ou de enfermidades graves, sobretudo se tem tratado de argumentar em casos de AIDS por esta via. Pelo contrário, uma valoração agravatória de uma escassa suscetibilidade da pena está proibida pelo princípio do Estado de Direito da proporcionalidade da pena com a gravidade do fato e a culpabilidade do autor" ${ }^{379}$.
\end{abstract}

É nesse sentido que o autor afirma que "um maior grau de sensibilidade à pena pode ver-se correspondido com uma diminuição do nível da intervenção penal” com vistas a uma maior humanização do Direito Penal, “sem afetar por isso a efetividade da luta contra o delito" 380

Em conclusão, afirma que "O princípio da culpabilidade não indica como deve ser penalizado o autor, senão como não pode ser penalizado. Para o 'como' da determinação da pena a acessibilidade à pena é um dos fatores decisivos no âmbito preventivo" ${ }^{381}$.

É nesse âmbito que se pode afirmar que os elementos subjetivos elencados no art. 59 do Código Penal devem ser sopesados na dosimetria da pena sob uma perspectiva de prevenção especial positiva com enfoque na não dessocialização do agente. Mais do que isso, devem servir tão somente para orientar o magistrado, dentro do marco da pena proporcional ao delito - após sopesados os critérios da culpabilidade e da gravidade do injusto - com o objetivo de determinar a pena mais adequada às condições pessoais (econômicas, familiares e sociais do agente), evitando-se, o quanto possível, o encarceramento, em busca de uma pena mais humana.

\footnotetext{
${ }^{378}$ Idem, ibidem, loc. cit..

${ }^{379}$ Idem ibidem, p. 355-356. É especialmente alarmante a jurisprudência nacional no que se refere à análise de suscetibilidade do agente à pena. É quase unânime entre os julgados consultados a prescrição de aumento de pena sob a justificativa de que condenações anteriores não foram suficientes para dissuadir o agente da comissão de novos delitos.

${ }^{380}$ Idem, ibidem, p. 356.

${ }^{381}$ Idem, ibidem, loc. cit..
} 
Nesses termos é possível afirmar que os antecedentes, a conduta social, a personalidade e os motivos do crime deverão ser avaliados pelo juiz para orientar à evitação da dessocialização do agente e nunca para fundamentar um agravamento da pena, porquanto já fixada dentro do marco da proporcionalidade ao fato cometido.

\subsubsection{Personalidade do agente}

Nessa linha de ideias, a circunstância personalidade do agente deve ser encarada sob uma ótica restritiva e garantista. Demetrio Crespo aborda o tema, partindo da premissa de que “Ao Direito Penal devem interessar, fundamentalmente, o conjunto de fatores existenciais que configuram sua atitude ante o protegido pelo direito penal porque só assim se pode avançar na averiguação da necessidade preventivo especial e da reação penal mais adequada para cumprir tal efeito" 382.

Aduzindo a sentenças do Tribunal Supremo Espanhol, Crespo afirma que a personalidade do delinquente representa uma apreciação complexa integrada por elementos psicológicos e a análise de sua projeção social, devendo ponderar-se suas condições pessoais de educação, entorno familiar, ofício, situação profissional ou econômica, valorando sua possível sensibilidade frente à pena e os efeitos dessa sobre sua vida ${ }^{383}$.

\footnotetext{
“Convém, em qualquer caso, afirmar que esse critério não pode conduzir a uma pena superior que a considere adequada à gravidade do fato (ademais, na determinação desta última, não cabe incluir as características pessoais do autor, o grau de sua oposição ao direito, nem outras características já existentes com anterioridade ao delito), senão que terá que jogar para baixo da pena adequada ao injusto culpável indicando se uma pena inferior é suficiente para produzir o efeito contramotivador que se persegue e evitar a dessocialização do réu. O campo que pode oferecer maior jogo a um critério individualizador preventivoespecial favorável ao réu é o dos substitutos penais” ${ }^{384}$.
}

\footnotetext{
${ }^{382}$ Idem, ibidem, p. 347.

${ }^{383}$ Idem, ibidem, loc. cit.. Diferente do que ocorre na jurisprudência brasileira, de onde se colhe com frequência um aumento de pena com base na personalidade do agente, após já ter sido sopesada a gravidade do fato, conforme se verá no Capítulo seguinte.

${ }^{384}$ Idem, ibidem, p. 347-348. Trad. livre.
} 
E, nesse caminho, concorda o autor que não é possível um aumento de pena com base na personalidade, por meio de uma maior censura da culpabilidade, sobretudo porque o injusto do fato não se vê influenciado de forma alguma pela personalidade. E adverte: “Além disso, isso seria o álibi perfeito para uma concepção moralizante, que transpassa a fronteira no sentido de uma culpabilidade pela condução de vida" ${ }^{385}$.

É por essa razão que afirma que a análise de personalidade pode assumir diferentes consequências, a depender do filtro por que passe segundo as diferentes funções da pena. Sob uma visão retributivista, a personalidade se atrela à culpabilidade e, com isso, castigase não o fato, mas seu autor. A pena justa e correta somente pode encontrar-se por meio da adequação de sua medida à personalidade do autor. "Dessa forma, diferentes autores cometendo o mesmo delito recebem penas diferentes segundo sua personalidade, sob o ponto de vista do princípio da culpabilidade/expiação" ${ }^{386}$.

De outro lado, sob o ponto de vista da prevenção especial positiva, é possível interpretar-se a personalidade sob a perspectiva da consideração das consequências da pena para a vida futura do réu, elegendo-se a pena que melhor proporcione ao agente menores chances de dessocialização.

A seguir, serão abordados os conceitos de personalidade do agente na doutrina e jurisprudência nacionais, suas acepções mais recorrentes e, por fim, a proposta de substituição do termo por outro que melhor expresse a ideia acima defendida.

\footnotetext{
${ }^{385}$ Idem, ibidem, p. 348. Trad. livre.

${ }^{386}$ Idem, ibidem, p. 349. Trad. livre.
} 


\section{PERSONALIDADE DO AGENTE E FIXAÇÃO DA PENA}

\subsection{O estudo da personalidade criminosa}

Conforme já se observou inicialmente, a Antropologia Criminal e a Criminologia, particularmente a Positivista, colocaram-se a serviço do Direito Penal com o fim de atender à nova ideologia da individualização da pena pelo estudo da personalidade do delinquente ${ }^{387}$.

Sob as mesmas premissas da ideologia de tratamento e de defesa da sociedade que inspiraram as alterações legislativas nos mais diversos países, a Antropologia Criminal perseguiu o mesmo objetivo, dedicando-se, com profundidade, ao estudo da personalidade do delinquente com a pretensão de auxiliar a Justiça Criminal.

O estudo do crime e do criminoso que se iniciou ainda com Lombroso desenvolveu-se em ramos específicos de conhecimento, passando por inúmeras modificações de enfoque ao longo dos séculos XIX e $\mathrm{XX}^{388}$.

O aprofundamento desses estudos, no entanto, não encontrou reflexos diretos na prática judiciária. A exigência de especialização de juízes e a necessidade de perícia antes da prolação da sentença são as duas principais conclusões a que se chega ao se confrontar os trabalhos desenvolvidos no campo da Antropologia Criminal e da Criminologia Clínica com a recomendação do art. 59, do Código Penal.

\footnotetext{
${ }^{387}$ A produção teórica e técnica nesse campo - cuja denominação mais adequada para os tempos atuais é Criminologia Clínica - é vasta e altamente especializada. Não é objeto deste trabalho o estudo da personalidade delinquencial, sobretudo o estudo técnico e especializado que a Criminologia Clínica desenvolve nesse campo, mas sim o estudo do conceito "personalidade" dentro do campo específico de aplicação da pena.

${ }^{388}$ É tormentosa a questão a respeito de qual seria a mais adequada denominação do ramo de conhecimento dedicado ao estudo do delinquente, com ênfase no estudo de personalidade. O mesmo objeto de estudo é abordado pelas mais variadas ciências e os próprios autores não são claros em definir um campo único de conhecimento sobre o tema. Assim, é possível que se encontrem estudos a respeito da personalidade do delinquente em obras da Antropologia Criminal, assim como em trabalhos da Criminologia Clínica ou Psicopatologia Criminal.
} 
Como exemplo, citam-se os trabalhos de Benigno Di Tullio, representante da Criminologia Clínica de viés médico-psicológico que se dedicou ao estudo de personalidade, particularmente sob a ideologia do tratamento e da defesa social.

A Antropologia Criminal, tida para ele como uma ciência total que engloba noções de Antropologia, Psicologia e Psicopatologia Geral, tem como papel estudar a personalidade do delinquente em todas as suas manifestações, de forma abrangente e completa, com a finalidade de colaborar com o Direito Penal:

\footnotetext{
"Sendo a Antropologia Criminal a disciplina chamada a ocupar-se, de maneira específica, do problema da criminalidade, considerada do ponto de vista biológico e social, em suas relações com as instituições sociais, de polícia, penais e penitenciárias, deve necessariamente valorar o conhecimento dos vários princípios e métodos científicos que pertencem aquelas outras disciplinas que se apresentam de maior interesse para o estudo das causas da criminalidade, para o exame da personalidade do delinquente, para o conhecimento da dinâmica criminal, para a valoração da capacidade para delinquir e da perigosidade criminal e para a aplicação de meios profiláticos e terapêuticos destinados seja a necessidade da defesa social contra a criminalidade que ao melhoramento físico e moral da nação" ${ }^{389}$.
}

Para Di Tullio, o juiz, para promover a individualização da pena e para atender à determinação da lei de precisar os móveis do delito, o caráter, os precedentes sociais e pessoais do réu, seu comportamento antes e depois do delito e sua perigosidade "deve conhecer necessariamente todos os importantes capítulos da Antropologia Criminal” ${ }^{390}$.

Sob uma abordagem fundamentalmente constitucionalista e biotipológica, Di Tullio propõe um estudo da personalidade que contemple os aspectos morfológico (desde a análise racial à medição de membros e partes do corpo), funcional (com exames de todos os aparelhos e sistemas do corpo humano), psicológico (incluindo exames de afetividade, vontade e moralidade) e ambiental (familiar e social) ${ }^{391}$.

${ }^{389}$ DI TULLIO, Benigno. Tratado de Antropologia Criminal, p. 32. Tradução livre.

${ }^{390}$ Idem, ibidem, p. 36.

${ }^{391}$ Di Tullio afirma haver um conjunto particular de características constitucionais que se podem considerar como indispensáveis ao desenvolvimento dos comuns fenômenos criminológicos, sintomáticos de uma verdadeira perigosidade social e criminal, à qual ele denomina de constituição delinquencial. Assim, a 
Ocorre que tal aprofundamento no estudo da personalidade do delinquente, sobretudo nos moldes experimentalistas das ideologias que o reclamavam, não poderia prescindir de campo e espaço próprios para sua realização ${ }^{392}$. A falta de adoção de medidas práticas nesse sentido pelo nosso ordenamento jurídico acabou por frustrar a pretensão de um estudo deste cariz ${ }^{393}$.

Por outro lado, o estudo da criminalidade e, particularmente, da personalidade delinquencial, aprofundou-se e ampliou-se largamente com reflexos diretos no campo da execução da pena. O modelo inicial médico-psicológico inaugurado pelos estudos de Lombroso modificou-se significativamente. Do determinismo biológico do homem atávico, a Criminologia passou, sucessivamente, para um determinismo psicológico e social e, finalmente, para uma visão multifatorial do criminoso ${ }^{394}$.

Assim, coube à doutrina e à jurisprudência, exclusivamente, a árdua tarefa de interpretar o conceito de personalidade do agente presente no rol de circunstâncias judiciais elencadas para a fixação judicial da pena.

\title{
4.2. O posicionamento da doutrina jurídico-penal brasileira
}

\begin{abstract}
presença de determinadas características físico-psíquicas seriam capazes de favorecer o desenvolvimento de reações criminosas, em razão de uma predisposição biológica. Idem, ibidem, p. 56.

392 É o que propõe o próprio autor, ao final de seu Tratado, sugerindo a especialização dos juízes (matéria amplamente debatida em nível internacional, como já visto inicialmente) ou a obrigatoriedade de perícias técnicas no curso da instrução processual.

393 Muitos autores entendem necessária a adoção do exame criminológico antes da sentença no nosso ordenamento penal. Zaffaroni e Pierangelli, embora tenham esse mesmo entendimento, advertem a respeito da inconstitucionalidade de tal medida: “(...) é de se insistir na necessidade de um estudo ou informe criminológico. Não obstante, o princípio constitucional de inocência impede - na nossa maneira de ver - a realização do informe criminológico de um processado. Cremos que, se efetivamente se quisesse implantar esse informe, se faria mister dividir o processo, ou juízo, em duas partes - como sucede, algumas vezes, nos Estados Unidos: na primeira se estabelecendo a autoria e a classificação legal do fato, e, numa segunda etapa, procede-se à individualização da pena. De outra maneira, pretender realizar um informe criminológico de um processado é penetrar no âmbito de privacidade e intimidade de uma pessoa, que a lei presume inocente, e que de modo algum autorizam os mais elementares princípios do Estado de Direito" (destaques nossos). ZAFARONI, Eugenio Raúl, PIERANGELI, José Henrique. Manual de Direito Penal Brasileiro, p. 710. Sob a mesma ótica, conferir ainda FRAGOSO, Heleno Cláudio. Lições de Direito Penal, p. 314 e NORONHA. E. Magalhães. A classificação de delinquentes no Novo Direito Penal, p. 99.

${ }^{394}$ Para uma abordagem profunda e completa sobre os modelos de Criminologia Clínica e um resumo das principais teorias de seus maiores representantes, bem como sua evolução no campo da execução penal, ver: SÁ, Alvino Augusto de. Criminologia Clínica e Execução Penal.
\end{abstract}


É possível afirmar que o termo “personalidade do agente” como elemento normativo não encontrou na doutrina penal brasileira e na jurisprudência de nossos tribunais um significado único. O tema é poroso e a própria aferição da personalidade, na prática judiciária, revela o distanciamento existente entre a interpretação dada pelos operadores do Direito e o conceito e sentido técnico próprios que possui no ramo específico de conhecimento a que pertence.

Isso porque o juiz, não sendo um especialista em Psicologia, na prática judiciária, acaba por aferir a personalidade do agente, no caso concreto, segundo seus próprios critérios subjetivos e impressões particulares. O termo acabou tomando na dogmática penal e na jurisprudência suas feições próprias, por meio das mais diversas formas de interpretação e adoção de distintos elementos relacionados à subjetividade do agente.

Não raro, encontra-se entre os doutrinadores penais nacionais e em alguns julgados de nossos tribunais a afirmação no sentido da impossibilidade de aferição da personalidade do agente por parte do juiz, por faltar-lhe conhecimento técnico ${ }^{395}$. De outro lado, também se encontram afirmações no sentido da prescindibilidade de tal conhecimento para que o julgador possa manejar referida circunstância no momento da aplicação da pena ${ }^{396}$.

Assim, não obstante a importância que o critério da personalidade assumiu perante nossa legislação penal e para a doutrina penal de fins do século XIX e início do século XX, especialmente sob a vigência do Código Penal de 1940, o conceito não encontrou um significado sólido nem uma definição definitiva.

\footnotetext{
${ }^{395}$ Importante a esse respeito a posição de Salo de Carvalho que adverte que a análise da personalidade pelo juiz não apresenta, no modelo garantista que defende, possibilidades de verificabilidade processual pelo juiz e pelas partes. Citando Paganella Boschi, afirma: "Definir a personalidade não é algo tão simples como pode parecer, sendo especialmente ao juiz muito mais tormentosa a questão, seja porque ele não domina conteúdos de psicologia, antropologia ou psiquiatria, seja porque possui, como todo indivíduo, atributos próprios de sua personalidade. Por isso, contata-se, na experiência cotidiana, que a valoração da personalidade do acusado, nas sentenças criminais, é quase sempre precária, imprecisa, incompleta, superficial, limitada a afirmações genéricas do tipo 'personalidade ajustada', 'desajustada', 'agressiva', 'impulsiva', 'boa', 'má', que, do ponto de vista técnico, nada dizem”. Apud DE CARVALHO, Salo. Aplicação da pena e garantismo, p. 54.

${ }^{396}$ Dentre os penalistas brasileiros da atualidade, Guilherme de Souza Nucci assim se posiciona: “O juiz não precisa ser um técnico para avaliar a personalidade bastando o seu natural bom senso, utilizado, inclusive e sempre, para descobrir a própria culpa do réu. Inexiste julgamento perfeito, infalível, pois sempre se trata de simples justiça entre seres humanos, de modo que o critério para analisar o modo de ser e agir de alguém constitui parte das provas indispensáveis que o magistrado deve recolher”. NUCCI, Guilherme de Souza. Individualização da pena, p. 192.
} 
Contudo, é majoritário na doutrina penal brasileira o estabelecimento de uma relação direta entre o conceito de personalidade e uma visão da culpabilidade derivada da culpabilidade pela conduta de vida ou pela formação da personalidade.

Francisco Toledo de Assis, opondo-se ao posicionamento majoritário, adverte para o perigo da adoção das concepções da culpabilidade derivadas de uma culpabilidade de autor (cujas denominações são várias: culpabilidade pelo caráter, culpabilidade pela conduta de vida, culpabilidade pela decisão de vida, culpabilidade pela formação da personalidade e culpabilidade da pessoa) ${ }^{397}$.

Afirma que as correntes mais importantes que se situam na linha de uma culpabilidade de autor (ainda que não expressamente assim assumidas) admitem o fato praticado como necessário "somente para a fixação do momento da exteriorização do caráter ou da personalidade censuráveis”, ou como pressuposto para a aplicação da lei ${ }^{398}$.

Adverte que, assim como se mostra impossível aferir a liberdade de agir de outro modo (principal justificativa dentre os que adotam a linha da culpabilidade de autor para rechaçar uma culpabilidade exclusivamente do “ato”), é igualmente impossível para o juiz identificar e apreender a liberdade do indivíduo de conduzir a própria vida ou de construir a própria personalidade ${ }^{399}$. A isso acrescenta a seguinte crítica, referindo-se às pesquisas desenvolvidas na área criminológica por Sheldon e Eleanor Glueck:

\footnotetext{
"O desenvolvimento anormal do caráter e da personalidade de um grande número de delinquentes pesquisados remonta à mais tenra infância e se explica por meio de fatores que de nenhum modo podem ser atribuídos aos seus portadores. Neste terreno, corre-se o risco de acabar-se com o conceito de culpabilidade penal e de transformar-se o direito penal em uma espécie de terapêutica psicológica, ou psiquiátrica. A toga seria substituída pelo avental branco" $^{400}$.
}

\footnotetext{
${ }^{397}$ Cf. TOLEDO, Francisco de Assis. Princípios básicos de direito penal, p. 242.

${ }^{398}$ Idem. Ibidem, loc. cit..

${ }^{399}$ Cf. TOLEDO, Francisco de Assis, ibidem, p. 244.

${ }^{400}$ Idem, ibidem, p. 246.
} 
O autor rejeita categoricamente qualquer pretensão de se tomar por base a personalidade do agente como forma de lhe mensurar a culpabilidade (censura):

\footnotetext{
"Seria, pois, perda de tempo (mais que isso, arbitrário) tentar apontar, na 'história da experiencial total' do indivíduo, que se entende vergado por toda uma série de fatores genéticos e ambientais algo que se lhe pudesse censurar a título de culpa. Com isso, retornamos ao conceito de culpabilidade do fato, esta sim, a nosso ver, a única capaz de fundamentar, no atual estágio de nossa cultura, um direito penal de culpa" ${ }^{401}$.
}

A doutrina majoritária, no entanto, conforme já se falou, relaciona a personalidade do agente na fixação da pena como elemento de aferição da culpabilidade. Ainda que se possa afirmar a adoção de uma linha moderada de culpabilidade de autor ou mesmo a prevalência de uma culpabilidade normativa de fato e de autor na doutrina nacional, a circunstância "personalidade”, via de regra, não se dissocia da ideia de análise da formação da personalidade ou da forma de condução de vida ${ }^{402}$.

Assim, constata-se a prevalência por uma interpretação da personalidade como sinônimo de caráter, de valores morais assumidos pelo agente, de sua forma de se comportar ou de se conduzir na vida e, especialmente, como expressão dos seus sentimentos manifestados no fato criminoso.

Mesmo dentre os penalistas brasileiros de maior importância na doutrina jurídicopenal as definições do termo "personalidade do agente" não se mostram precisas, apresentando-se, na maior parte das vezes, como conceitos vagos, incapazes de conferir a necessária segurança e racionalidade que um critério de fixação da pena deve oferecer ao operador da lei.

\footnotetext{
${ }^{401}$ Idem, ibidem, p. 250.

${ }^{402}$ Como exemplo de exceção, o posicionamento de José Frederico Marques, para quem a circunstância personalidade deve ser manejada exclusivamente como fator de individualização da pena, e não como fator mensurador da culpabilidade. $\mathrm{O}$ autor ainda critica os posicionamentos na doutrina penal que adotam as vertentes da culpabilidade pela formação da personalidade ou pela conduta de vida. Contudo, retrocede ao aproximar os conceitos de "personalidade" e "periculosidade", afirmando que a personalidade, na fixação da pena, é "objeto precípuo do juízo de periculosidade, para que se verifique da probabilidade de novo crime". MARQUES, José Frederico. Tratado de Direito Penal, p. 93.
} 
Anibal Bruno, interpretando o art. 42 do Código Penal de 1940, definiu o conceito de personalidade nos seguintes termos:

\begin{abstract}
"Personalidade é o todo complexo, porção herdada e porção adquirida, com o jogo de todas as forças que determinam ou influenciam o comportamento humano. A personalidade é uma realidade naturalística, cuja compreensão os dados antropológicos, em largo sentido, concorrem para esclarecer” ${ }^{403}$.
\end{abstract}

Para esse autor, a investigação do juiz não pode estar apartada dos conhecimentos técnicos e científicos:

\begin{abstract}
"Seria absurdo que este se pusesse a decidir em matéria de tamanha relevância, pondo deliberadamente de parte as contribuições com que aquelas ciências, que constituem um setor tão importante da nossa cultura, tentam a aproximação desse mundo íntimo e dificilmente abordável, que é a personalidade humana” ${ }^{404}$.
\end{abstract}

Além desses conhecimentos, Anibal Bruno defende que o juiz deve utilizar-se da análise do seu mundo circundante, seus antecedentes (na medida em que contribuiriam para lhe definir a personalidade, a forma normal de seu comportamento), as reações que costuma opor às provocações do ambiente e que seriam sinais reveladores da sua maneira de ser, seus hábitos no seio familiar, social, além de seus antecedentes penais e judiciais ${ }^{405}$.

O renomado autor deixa claro que, na análise da personalidade do agente, deve-se identificar o quanto de sua esfera íntima está presente no fato praticado, ou seja, o quanto aquele ato é a própria expressão de sua personalidade, deixando clara a ideia de que a reprovabilidade recai sobre a subjetividade do autor, exteriorizada no fato praticado:

\footnotetext{
“Será em todo caso importante determinar se o fato punível é expressão autêntica da personalidade do autor ou um extravio insólito da sua linha de conduta habitual, condicionado decisivamente por influências estranhas à sua própria natureza. E o peso da reprovabilidade será tanto mais forte quanto maior for a cota do pessoal e íntimo do agente na determinação do seu ato, isto é,
}

\footnotetext{
${ }^{403}$ Direito Penal. Parte Geral. Forense, Rio de Janeiro, 1978, p. 154. Essa definição se vê repetidamente reproduzida entre os mais diversos doutrinadores, até o momento atual.

${ }^{404}$ Idem, ibidem, p. 155.

${ }^{405}$ Idem, ibidem, loc. cit..
} 
quanto mais profundamente mergulharam as raízes do crime na sua personalidade. Mas tudo isso o juiz fará na medida em que for necessário e lhe seja possível entregar”406.

Em uma elaboração mais ampla do conceito, Nelson Hungria acrescenta outros elementos à formação da personalidade que, no seu entender, não se restringe às influências dos fatores endógenos e ao meio circundante. Para ele, “a personalidade não é simples conjugação de tendências inatas e pressões mesológicas, pois entre tais fatores sempre evolui a vontade livre, com sua atividade própria, e precisamente esse quantum de liberdade volitiva é que torna relativa a estabilidade do modo de ser habitual” ${ }^{407 .}$

Hungria critica a forma como a Criminologia Positivista procurou estudar a personalidade do delinquente, pois levou à criação de uma tipologia de criminosos. Sua concepção parte de um conceito dinâmico da personalidade e, por isso, defende uma “nova” Criminologia a que denomina de “Criminologia de casuística”. Nessa vertente, afirma que a análise da personalidade pelo magistrado deve perder seu caráter científico e renunciar a concepções generalizadoras:

\footnotetext{
“O que é necessário fazer, em lugar de classificações abstratas e precárias, é procurar retraçar, em cada caso corrente, dentro das possibilidades práticas, a personalidade individual concreta do criminoso, mediante a elucidação do seu curriculum desde a infância, no lar, na escola, no grupo social a que pertence, no ambiente em que viveu" ${ }^{408}$.
}

Para Heleno Cláudio Fragoso, a personalidade é o elemento que mais se destaca dentre aqueles que deverão ser analisados pelo juiz na fixação da pena: “O juiz ajusta $a$ pena ao autor concreto do crime, atendendo às particularidades de sua personalidade moral (caráter) e examinando se a conduta delituosa constituiu fator acidental ou se é expressão da maneira de ser que o acusado apresenta” ${ }^{409}$. Como critério de aferição da personalidade, o autor afirma que o juiz deverá considerar os antecedentes, ou seja, o comportamento anterior do acusado.

\footnotetext{
${ }^{406}$ BRUNO, Anibal. Direito Penal. Parte Geral, p. 155.

${ }^{407}$ HUNGRIA, Nelson. Comentários ao Código Penal. Apêndice - A classificação dos criminosos, p. 400.

${ }^{408}$ Idem, ibidem, p. 399-400.

${ }^{409}$ FRAGOSO, Heleno Cláudio. Lições de Direito Penal. Parte Geral, p. 314.
} 
José Frederico Marques, adotando um conceito de personalidade mais próximo do pensamento antropológico, entende a personalidade de forma ampla e complexa. Na sua definição:

\begin{abstract}
“A personalidade do homem é a síntese dos elementos biopsíquicos que o compõem. O homem, lembra Gemelli, é um microcosmo. Nele reúnem-se, num todo perfeitamente composto e conjugado, as propriedades da matéria, os graus inferiores da vida manifestados na atividade sensória e nos instintos, de par com as exteriorizações mais altas de faculdades superiores como a inteligência, a vontade e os sentimentos. Cimentados em sólida e viva unidade, esses elementos não se encontram, por isso mesmo, dispersos e justapostos.: há uma interpenetração de todas as atividades que o ser humano desenvolve, que vai da vida orgânica à vida dos sentidos, da vida dos instintos, hábitos, inclinações à superestrutura fundamental da inteligência e do querer. Por mais heterogênea que pareçam, não passam, todas essas atividades, de funções de uma única vida humana. Daí a conclusão de Gemelli, de que um quadro completo do ser humano concreto e vivo é constituído tanto pelo organismo corporal, como pela vida interior, conjugados em um todo de unidade incindível resultante da integração de suas múltiplas partes e segmentos, cuja culminância se encontra em um vértice que é ao mesmo tempo o resumo de seus diversos elementos: a personalidade, ${ }^{410}$.
\end{abstract}

Julio Fabrini Mirabete também entende a personalidade como sinônimo de caráter e dos valores morais do agente: “Quanto à personalidade, registrem-se as qualidades morais, a boa ou má índole, o sentido moral do criminoso, bem como sua agressividade $e$ o antagonismo com a ordem social, intrínseco a seu temperamento" ${ }^{411}$.

Paulo José da Costa Junior vincula o sentido do termo personalidade à conduta do agente. Para ele, a personalidade está intimamente ligada à conduta e, portanto, não poderá ser analisada separadamente pelo juiz ${ }^{412}$.

${ }^{410}$ Exatamente em razão do caráter complexo da personalidade, o autor entende que “(...) não se pode estudar o delinquente, para situá-lo no plano normativo do Direito Penal, sem um complexo exame de todos os elementos que o compõem". Op. cit., p. 90.

${ }^{411}$ MIRABETE, Julio Fabrini. Manual de Direito Penal, p. 285.

${ }^{412}$ Uma interpretação desse molde restringe a análise da personalidade ao fato praticado e, portanto, confere maior segurança e racionalidade ao processo de dosimetria da pena, na medida em que se limita a avaliar a personalidade exteriorizada naquele fato específico, e não no modo do agente de ser e de se conduzir na vida, tampouco pelos de seus antecedentes. Contudo, também para esse autor a avaliação da personalidade carrega 
Dentre os autores modernos, o conceito de personalidade, contrariando a doutrina tradicional sobre o tema, recebe um tratamento distinto, sob um viés crítico.

Juarez Cirino dos Santos aponta que o conceito de personalidade é controverso, tanto para o Direito Penal como para a Psicologia e a Psiquiatria, em razão de seus limites imprecisos. Em razão disso, o autor posiciona seu entendimento de forma crítica, ressaltando que a interpretação do conceito de personalidade para a doutrina e a jurisprudência acaba se resumindo nas impressões pessoais do intérprete da lei:

\footnotetext{
"Os operadores do sistema de justiça criminal não possuem formação acadêmica em Psicologia ou Psiquiatria para decidir sobre o complexo conteúdo do conceito de personalidade, e por essa razão, a jurisprudência brasileira tem atribuído um significado leigo ao conceito, como conjunto de sentimentos/emoções pessoais distribuídos entre os pólos emotividade/agressividade, que pouco indicam sobre a personalidade do condenado - um resultado agravado pela ausência do princípio da identidade física do juiz no processo penal, com interrogatório realizado por um e a sentença proferida por outro juiz criminal”413.
}

Também sob um viés crítico, Juarez Tavarez ressalta que é bastante comum, em razão do disposto no art. 67 do $\mathrm{CP}$, que a personalidade seja utilizada como fator preponderante entre as circunstâncias agravantes e atenuantes e como instrumento definitivo para contornar os limites da culpabilidade e impor ao infrator uma pena fora da proporcionalidade para com o fato por ele praticado ${ }^{414}$.

A esse respeito, o autor afirma que, em primeiro lugar, a personalidade como critério de prevenção geral e especial não pode implicar a fixação da pena além dos limites impostos pela culpabilidade, pois isso importaria em violação aos princípios objetivos da legalidade e da proporcionalidade. Trata-se de uma orientação que contraria o entendimento da doutrina majoritária e tradicional:

um sentido moral e ético, pois, para ele, se o agente revelar, por exemplo, “acentuada indiferença afetiva” no fato criminoso deverá ser mais severamente punido e, se não demonstrar ódio pela vítima, nem brutalidade ou violência poderá receber tratamento menos rigoroso. Cf. COSTA JUNIOR, Paulo José da. Op. cit., p. 201. ${ }^{413}$ SANTOS, Juarez Cirino dos. Teoria da pena: fundamentos políticos e aplicação judicial, p. 113.

414 TAVAREZ, Juarez. Culpabilidade e individualização da pena, p. 149. 
"De diferente modo do que se propunha no começo do século XX, as qualidades da personalidade não se concentram no caráter da pessoa, nem em sua constituição, e, sim, nas disposições relativamente duradouras que se manifestam em diversas situações e durante algum lapso de tempo, de modo a indicar se aquela pessoa estaria condicionada ou livre para realizar determinado comportamento. Normalmente, a aferição da personalidade é conduzida sobre elementos da percepção diária, levada a efeito pelas manifestações da pessoa em seu ambiente. Segundo as dificuldades na coleta dos dados dessa percepção, é comum mesclarem-se a isso todos os preconceitos, estereótipos e juízos negativos que não lhe pertencem e, sim, aos conceitos morais, nem sempre correspondentes ao ambiente real da manifestação personalista. A afirmação no sentido de que o autor tem personalidade voltada para o crime, diapasão básico das sentenças criminais, inclui-se no âmbito desses preconceitos ou esteriótipos, pertencendo, assim, a um juízo moral negativo, que nada tem a ver com a avaliação efetiva da personalidade, ou da vida mental do sujeito, em confronto com a sua forma de adaptação ao ambiente” ${ }^{415}$.

O autor entende a personalidade referida no artigo 59, do CP, como "manifestação da decisão autônoma do sujeito para a realização da conduta” e, dessa forma, deve ser entendida como um processo mental de produção e delimitação da autonomia do sujeito (muito embora seja de difícil aferição no caso concreto) ${ }^{416}$.

No seu entendimento, a personalidade estaria mais ligada à sua capacidade de autodeterminação frente à norma do que a um condicionamento, desvalor moral ou sentimento do agente que o levam à prática delitiva. Tavarez defende que a "personalidade se baseia na autonomia do sujeito em se integrar ao ambiente, em um processo de comunicação. Se ele não puder se integrar ao ambiente, em virtude de déficit considerável de socialização, para o qual não tenha contribuído, e dessa forma, não for capaz de se motivar conforme os apelos da norma, sua responsabilidade deverá ser limitada” ${ }^{417}$.

Nessa perspectiva, conclui:

\footnotetext{
${ }^{415}$.Idem, ibidem, loc. cit..

${ }^{416}$ Idem, ibidem, passim.

417 Idem, ibidem, p. 150. Parece-nos que esse conceito, portanto, está concebido como critério da própria culpabilidade da teoria do delito, e não como elemento de prevenção especial, uma vez que o autor não o menciona como fator de determinação da pena, mas sim como fator de redução da própria reprovabilidade da conduta.
} 


\begin{abstract}
"A personalidade, ao contrário do que se afirma comumente nas sentenças criminais, funciona, assim, como um instrumento de limitação da responsabilidade. Na medida em que se reconheça no sujeito uma personalidade, pode ele ser responsabilizado; se ocorrer um distúrbio da personalidade, esse fato implica o reconhecimento de um problema de socialização, que pode conduzir a uma atenuação da pena (...) A consideração da personalidade em função da autonomia do sujeito, e sua repercussão na individualização da pena, como fator de limitação, corresponde também, em certa medida, ao proposto pela moderna teoria do injusto culpável, de não admitir que a pena possa ser exasperada por circunstâncias estranhas àquelas que fundaram o desvalor do fato típico e antijurídico e que deram lugar ao conteúdo da culpabilidade” ${ }^{\text {} 418}$.
\end{abstract}

Contrariando a tendência mais moderna da doutrina, que se volta a um posicionamento crítico a respeito da legitimidade da personalidade do agente como circunstância judicial para fixação judicial da pena, Guilherme de Souza Nucci compartilha o antigo posicionamento da doutrina tradicional.

Para esse autor, as circunstâncias subjetivas devem sempre prevalecer sobre as objetivas no caso de confronto, conforme prescreve o artigo 67 do Código Penal. Justifica a necessidade de valorizarem-se os aspectos subjetivos relacionados ao agente (e não apenas a personalidade) porque “julgar não é tarefa de matemáticos nem de computadores, sendo deplorável a (nem sempre incomum) pena padrão, que elimina as evidentes diversidades entre os réus" ${ }^{419}$.

Define o conceito de personalidade como "o conjunto de caracteres exclusivos de uma pessoa, parte herdada, parte adquirida" ${ }^{420}$. Cita, como exemplos de elementos da personalidade que podem ser buscados na análise do modo de ser do agente, os seguintes:

\footnotetext{
${ }^{418}$ Idem, ibidem, p. 151.

${ }^{419}$ NUCCI, Guilherme de Souza. Individualização da pena, p. 174-175. O autor reconhece expressamente que a subjetividade presente na legislação brasileira possui inegável influência da Escola Positiva. Segundo ele: "O que de útil nos legou a Escola Antropológica do Direito Penal é justamente a constatação de que não se pode igualar o desigual e que, se a pena busca a regeneração como um dos seus fins, não se pode afastar a matéria extrapenal desse processo. A missão do julgador na avaliação subjetiva do réu, longe de representar desapego à legalidade, insegurança para o acusado, fomento à discricionariedade exagerada ou mesmo incremento do abuso punitivo, representa seu dever legal e constitucional”. Op. cit., p. 176-177. ${ }^{420}$ Idem, ibidem, p. 186.
} 
“a) aspectos positivos: bondade, alegria, persistência, responsabilidade nos afazeres, franqueza, honestidade, coragem, calma, paciência, amabilidade, maturidade, sensibilidade, bom-humor, compreensão, simpatia, tolerância, especialmente à liberdade de ação, expressão e opinião alheias; b) aspectos negativos: agressividade, preguiça, frieza emocional, insensibilidade acentuada, emotividade desequilibrada, passionalidade exacerbada, maldade, irresponsabilidade no cumprimento de obrigações, distração, inquietude, esnobismo, ambição desenfreada, insinceridade, covardia, desonestidade, imaturidade, impaciência, individualismo exagerado, hostilidade no trato, soberba, inveja, intolerância, xenofobia, racismo, homofobia, perversidade” ${ }^{421}$.

Tais fatores, segundo o autor, devem ser considerados no contexto do fato praticado, e não como fatos isolados ou quando não repercutem no desrespeito ao direito de terceiros. Para Nucci, se alguma das características negativas elencadas for o móvel propulsor do crime, tal elemento deverá ser tomado em conta para o estabelecimento da pena $^{422}$.

A jurisprudência nacional mostra-se bastante divergente a respeito do conceito de personalidade e quanto à eleição de critérios materiais de aferição. Ainda que se admita, conforme afirma Paulo José da Costa Junior, que em função da personalidade o juiz poderá tanto exacerbar como atenuar a pena, na maior parte das vezes, segundo a jurisprudência selecionada, a personalidade e outros elementos subjetivos relacionados ao agente servem recorrentemente como porta aberta para um aumento de pena desproporcional ao fato praticado $^{423}$.

A seguir, serão apresentados alguns exemplos extraídos da jurisprudência que revelam a interpretação do conceito de personalidade e os critérios utilizados para sua aferição.

\footnotetext{
${ }^{421}$ Idem, ibidem, p. 187

${ }^{422}$ Idem, ibidem, loc. cit.. Ainda que se considerem os elementos tidos como "negativos" da personalidade apenas relacionando-os ao fato criminoso praticado, não é possível concordar com o autor que tais aspectos devam importar para a fixação da pena, especialmente porque o resultado final desse processo seria o mesmo que apenar mais gravemente o agente em razão de suas características pessoais e da sua subjetividade. Ademais, a dificuldade em se avaliar com a necessária segurança a efetiva presença ou ausência de tais características na subjetividade do acusado torna tal pretensão impossível de se adotar no processo criminal, além de afrontar a liberdade individual de cada indivíduo, que tem o direito de sentir, ser e pensar como quiser.

${ }^{423}$ Cf. COSTA JUNIOR, Paulo José da. Op. cit., p. 201.
} 


\title{
4.3. Acepções do termo e critérios de aferição segundo a jurisprudência brasileira
}

A jurisprudência brasileira revela uma surpreendente irracionalidade em matéria de fixação da pena e de análise da personalidade como circunstância judicial. Se a intenção do legislador com a inserção da personalidade do agente como fator de fixação da sanção penal foi permitir a individualização da pena ao autor, limitando o juiz por uma discricionariedade vinculada, não é o que se pode observar da experiência jurisprudencial.

Em Penas e medidas de segurança, Miguel Reale Junior, dentre outros autores que participaram da Reforma da Parte Geral do Código Penal, de 1984, ressaltam que a Nova Parte Geral do CP tornou mais amplo o poder discricionário do juiz, acentuando a cada passo a tarefa de individualização da sanção penal, tornando um verdadeiro mote a referência às circunstâncias, às quais o juiz deve recorrer, tanto para escolher esta ou aquela modalidade e quantidade de pena, como para optar entre um ou outro regime de cumprimento.

O móvel da Reforma era fornecer um maior leque de opções ao juiz, que passaria a contar com maiores condições e subsídios para optar por outras medidas que não exclusivamente a pena privativa de liberdade:

\begin{abstract}
“(...) o alargamento do poder discricionário do magistrado é ,aliás, decorrência obrigatória da criação de um leque de opções graças às penas substitutivas, a exemplo do que ocorreu com a Lei de novembro de 1981, Lei ${ }^{\circ}$ 689, considerando o mestre Nuvolone ser 'uma nota característica desta reforma a ampliação do poder discricionário do juiz, uma discricionariedade vinculada” ${ }^{424}$.
\end{abstract}

Contrariando a expectativa da Reforma, o que é possível verificar da experiência jurisprudencial é um verdadeiro descaso para com a regra da discricionariedade vinculada. Como bem ressalta Paulo José da Costa Junior, não são suficientes, no processo de individualização da pena “(...) aquelas fórmulas rituais e preguiçosas: 'entende-se equânime a pena', 'adequada ao fato e à personalidade', 'levando-se em conta os

${ }^{424}$ REALE JÚNIOR, Miguel ... [et al.]. Penas e medidas de segurança no novo código, p. 159. 
elementos do art. 59', etc. A adoção dessas fórmulas significa o arbítrio, jamais a discricionariedade ${ }^{425}$. No entanto, isso é o que recorrentemente se colhe da jurisprudência.

Ademais, diversas acepções e critérios de aferição distintos são tomados pelos julgadores para dar sentido ao termo "personalidade", sem que tenham necessariamente alguma relação com o fato praticado pelo agente e com o conteúdo das provas colhidas no processo. A aferição da personalidade, em última instância, fica a cargo da intuição dos juízes, segundo um enredo que não necessariamente se revela pelo conteúdo do processo.

Sem esgotar todas as acepções e critérios de aferição que podem ser encontrados na jurisprudência, as mais recorrentes serão elencadas exemplificativamente a seguir.

\subsubsection{Personalidade como sentimentos e valores morais negativos}

A concepção de personalidade como sinônimo de valor moral ou dos sentimentos negativos do agente aparece majoritariamente na jurisprudência como fator de agravamento da pena. A seguir, alguns exemplos colhidos da jurisprudência.

O Tribunal Regional Federal da $3^{\mathrm{a}}$ Região, em Apelação Criminal interposta pelos réus, para justificar a manutenção da reprimenda fixada em primeira instância, ressaltou o aspecto negativo das personalidades dos acusados, considerando-as como sinônimo dos sentimentos dos réus manifestados no delito - no caso, "ambição desmedida $e$ oportunismo exacerbado" — revelando também um significado relacionado aos seus (supostos) valores morais. Do voto vencedor extrai-se o seguinte trecho:

\footnotetext{
“Trata-se, na verdade, de pessoas inescrupulosas, egoístas e arrogantes, não podendo o julgador ignorar o conjunto dos fatos apresentados pela acusação, do qual se pode perceber claramente que possuem personalidade voltada para a busca de lucro fácil, denotando total desprezo pelo ente público que acolheu as acusadas em seu quadro de funcionários. No caso dos autos, restou patente que a conduta social inadequada, a personalidade deturpada das acusadas e as
}

${ }^{425}$ Op. cit., p. 198. 
circunstâncias nefastas do crime, além da culpabilidade exacerbada, por terem elas se aproveitado do fato de serem funcionárias do Instituto Nacional do Seguro Social para fraudar, de forma sistemática, a previdência social brasileira, determinam que a resposta estatal seja exercida de forma mais rigorosa” ${ }^{426}$.

Em julgamento de habeas corpus pelo Superior Tribunal de Justiça, o entendimento vertido no acórdão também foi em sentido similar. A Corte Superior considerou que a personalidade deve ser entendida como sinônimo dos sentimentos negativos que o agente manifesta na prática do crime. Fundamentando seu voto no entendimento doutrinário de Guilherme de Souza Nucci, a Ministra relatora afirmou que a personalidade “(...) deve ser entendida como a agressividade, a insensibilidade acentuada, a maldade, a ambição, a desonestidade e perversidade demonstrada e utilizada pelo criminoso na consecução do delito" ${ }^{427}$.

Também da Corte Superior de Justiça colhe-se decisão que entendeu a personalidade como sinônimo das qualidades morais e sentimentos do criminoso, com a ressalva de que devem ser consideradas também as condições pessoais de vida do réu, ainda que em menor medida:

\footnotetext{
“Quanto à personalidade, devem ser lembradas as qualidades morais do agente, a sua boa ou a má índole, o sentido moral do criminoso, bem como sua agressividade e o antagonismo em relação à ordem social e seu temperamento, também não devendo ser desprezadas as oportunidades que teve ao longo de sua vida e consideradas em seu favor uma vida miserável, reduzida instrução e deficiências pessoais que tenham impedido o desenvolvimento harmonioso da sua personalidade. Ademais, o conceito de personalidade como circunstância judicial diz respeito ao temperamento do agente, não se confundindo com os antecedentes criminais" ${ }^{428}$.
}

O Tribunal de Justiça da Bahia, em julgamento de Apelação Criminal, reafirmou a sentença de primeira instância, na qual a personalidade do réu foi tida como

\footnotetext{
${ }^{426}$ TRF3, AC-0002017-37.2001.4.03.6181/SP, Rel. Des. Ramza Tartuce, DJe 18.11.11.

${ }^{427}$ STJ, HC 50.331/PB, Rel. Min. Laurita Vaz, DJ 06/08/2007.

${ }^{428}$ STJ, HC 107.795, Rel. Min. Og Fernandes, Rel. p/ acórdão Min. Jane Silva, DJe 02/03/2009. A definição é de Julio Fabrini Mirabete, embora não tenha sido citado no corpo do acórdão.
} 
“descontrolada e malvada, ausentes aí, todos os preceitos morais necessários ao pleno exercício da cidadania”.

A condenação de primeira instância havia justificado a exacerbação da pena-base substancialmente com fundamento em características subjetivas do acusado, deduzidas pelo magistrado a partir das circunstâncias do fato - não necessariamente comprovadas nos autos. Da sentença, o trecho sobre a dosimetria da pena-base:

\footnotetext{
“Iniludível a intensidade do dolo com que agiu o réu, manifestada através de sua conduta desequilibrada e indigna, inteiramente concentrada e dirigida contra um cidadão indefeso, com 65 anos de idade, cerca de $50 \mathrm{~kg}$, atrocidade, por incrível que pareça, dentro de uma Clinica, nesta Capital. A arrogância como cometeu o homicídio, que premeditou com ódio extremado, e revelador que o Réu tem uma personalidade descontrolada e malvada, ausentes ai, todos os preceitos morais necessários ao pleno exercício da cidadania. Revela comportamento intranquilo, prenhe de instabilidade, embora esboce conduta social relativamente normal. Agiu com acentuado dolo, que encontrou base na sua natureza violenta e perversa, fruto de uma estrutura que o acompanha, de prepotência e arrogância, aliada à delirante vaidade e lastimável falta de respeito para com seus semelhantes" ${ }^{429}$.
}

A concepção da personalidade como sinônimo de valores morais ou dos sentimentos do acusado, ora destacada nos julgados selecionados, parece-nos das mais perigosas formas de interpretação dessa circunstância judicial.

Em primeiro lugar, porque a impossibilidade de se aferir por meios seguros e legítimos quais valores ou sentimentos do acusado estiveram presentes na prática do delito acarreta a consequência nefasta de deixar a cargo da impressão pessoal do julgador essa tarefa. A forma como o magistrado enxerga a prática do delito não necessariamente corresponde ao que efetivamente foi sentido e pensado pelo agente, nem aos valores que por ventura carrega consigo e que estiveram presentes na prática do fato criminoso.

${ }^{429}$ TJBA, AC 29958-9/2008, Rel. Des. Lourival Almeida Trindade, j. 19/05/2009. O Tribunal de Justiça da Bahia negou provimento ao apelo do réu e considerou que a fixação da pena-base pelo magistrado de primeira instância foi “satisfatoriamente fundamentada”. A condenação a 21 (vinte e um) anos de reclusão (sem direito a recorrer em liberdade) foi mantida. 
Em segundo lugar, há que se destacar que, na linha do que vimos defendendo no presente trabalho, os sentimentos e os valores morais do acusado não devem ter relevância para a determinação da pena, sobretudo se não tiveram relevância para o grau de desvalor da ação. A proporcionalidade da pena com o fato, como já se disse, deve servir de limite à discricionariedade do juiz, e os elementos subjetivos devem atuar apenas para atenuar a pena ou para fornecer opções ao magistrado de alternativas à pena privativa de liberdade, quando assim se mostrar suficiente para seus fins de reprovação e prevenção.

\subsubsection{Personalidade como expressão do modo de ser, do comportamento pessoal e da conduta de vida}

Na doutrina brasileira a personalidade entendida como expressão do modo de ser do agente tem predileção entre os autores. Também na jurisprudência, e com apoio na doutrina tradicional, colhem-se inúmeros julgados relacionando a personalidade do agente ao seu comportamento, expressado no fato ou não. Abaixo, alguns julgados selecionados da jurisprudência dos mais diversos tribunais nacionais.

O Supremo Tribunal Federal, instado a manifestar-se em sede de habeas corpus sobre a pena aplicada pela primeira instância, posteriormente confirmada pelo Tribunal de Justiça de Minas Gerais, manteve condenação fixada no dobro do mínimo para réus primários e de bons antecedentes.

A justificativa para o aumento de pena vertido na sentença aduzia tão somente às personalidades dos agentes, avaliadas negativamente pelo magistrado sentenciante em razão do comportamento dos acusados.

A personalidade foi aferida no caso concreto pela consideração do "contato anterior com o mundo do tráfico ilícito", muito embora a sentença tenha reconhecido expressamente a primariedade dos réus e a presença de bons antecedentes. Afirmou-se, 
ainda, que os acusados "são dados à mentira, sofrem de péssima memória e não revelam temor ou censura que os impeçam viver do crime" ${ }^{430}$.

O D. Ministro relator entendeu o processo de dosimetria como razoável e manteve a condenação nos moldes da sentença por não vislumbrar ausência de fundamentação: “Assim, não se pode dizer da ausência de fundamentação. A fixação da pena-base ocorreu, é certo, com algum rigor, mas sem discrepar da ordem jurídica, a ponto de ter-se como configurado o constrangimento" ${ }^{431}$.

Do Tribunal de Justiça de São Paulo colhe-se julgamento no qual a personalidade havia sido avaliada pelo juiz de primeira instância com o auxílio de laudo de Avaliação de Personalidade e Estudo Social. Baseando-se em alguns trechos do referido laudo, o magistrado sentenciante, ao dosar a pena, considerou a personalidade do réu negativamente, fundamentando o aumento de pena em patamar distante do mínimo legal com base em elementos comportamentais do agente:

\begin{abstract}
“Como afirma o próprio laudo de Avaliação Psicológica de fls. 174/175, o réu possui '... personalidade ainda imatura e deficiências no aspecto afetivo emocional que podem levá-lo a descontroles no comportamento... ' (sic). No mesmo sentido, o laudo de Estudo Social de fls. 170/171 afirma que: ‘... colegas revelam que tem o hábito de, nas conversas, sempre levar o assunto para o lado sexual, alardeando suas conquistas neste aspecto e, por causa disso, é considerado uma pessoa cansativa, inconveniente e imatura...'(sic)” ${ }^{432}$.
\end{abstract}

A pena e seus fundamentos de fixação foram mantidos integralmente em segunda instância.

Em ambos os exemplos citados constata-se que a justificativa para o aumento da pena faz referência a aspectos relacionados ao agente que não guardam relação imediata com o fato praticado e também não podem ser considerados como sendo de seu domínio pessoal. As características apontadas nas sentenças constituem a própria maneira de ser do

\footnotetext{
${ }^{430}$ Não se pode deixar de criticar a análise do julgador que, ao fundamentar o aumento no dobro da pena mínima prevista para o crime, o fez com fundamento em critérios fluídos e imprecisos, como, por exemplo, o fato de "serem dados à mentira". Ao assim proceder, o magistrado sentenciante acabou por dissociar a pena aplicada do fato praticado.

${ }^{431}$ STF, HC 74.139-8/MG, Rel. Min. Marco Aurélio, DJ 21.02.97.

${ }^{432}$ TJSP - AC 261.4913 - Rel. Antonio Manssur, j. 04.10.99.
} 
réu, o seu comportamento pessoal ${ }^{433}$. Assim, é possível afirmar que os réus daqueles processos foram mais severamente apenados pela maneira como se comportam, e não em razão de elementos diretamente relacionados com os fatos pelos quais foram julgados.

A personalidade também é frequentemente avaliada pela jurisprudência como base no comportamento do agente em momento posterior ao delito, servindo, da mesma forma, como fundamento de aumento de pena.

O Juízo Criminal da Comarca Birigui/SP, em julgamento de crime de roubo de cento e cinquenta reais em dinheiro, apenou o réu em 7 (sete) anos, 3 (três) meses e 3 (três) dias, em regime inicial fechado. A pena-base foi aumentada de 1/6 em razão da "personalidade voltada para o crime”. O fundamento da sentença para aferição da personalidade criminosa, no entanto, faz referência a crimes praticados após o cometimento do delito:

“O acusado é reincidente (fl. 09 do apenso de certidões), além do que responde a outros dois processos criminais em andamento, um pela prática de roubos e outro porte de arma de fogo e receptação, ambos já com condenação em primeira instância (fls. 11 e 15 do respectivo apenso), evidenciando-se, pois, que possui personalidade totalmente voltada para a prática de roubos e outros delitos patrimoniais, razão pela qual as circunstâncias do artigo 59 do Código Penal não lhes são favoráveis” ${ }^{434}$.

A $16^{\text {a }}$ Câmara Criminal do Tribunal de Justiça de São Paulo reformou a sentença nesse ponto, reduzindo a pena-base ao mínimo legal. $\mathrm{O}$ d. relator assim fundamentou seu voto:

“(...) considerar que conduta mais recente possa elevar a pena de delito cometido anteriormente em razão da demonstração de personalidade voltada para o crime é

\footnotetext{
${ }^{433}$ No último exemplo, a imaturidade da personalidade, as deficiências emocionais, o fato de haver relatos no sentido de ser uma pessoa "cansativa”, "inconveniente” e "imatura” constituem seu modo de ser e não agravaram, de outro lado, o fato praticado. Nessa medida, não se pode afirmar que exerceram relevância para um maior ou menor desvalor da ação, nem incidiram sobre a gravidade do fato.

434 Segundo o acórdão proferido pelo Tribunal de Justiça de São Paulo, “(...) as certidões mencionadas tratam de delitos praticados em datas posteriores ao crime em questão (30/12/2009 e 20/04/2009, fls. 11 e 15)" (destacamos). O crime de roubo deu-se em 28 de dezembro de 2008. (TJSP, 16 ${ }^{\text {a }}$ Câmara Criminal, AC0008866-48.2009.8.26.0077, Rel. Des. Otávio de Almeida Toledo, j. 10.01.12).
} 
prática que muito se aproxima da ideia de Direito penal do Inimigo, teorizado por Jakobs. Ensina o professor Antonio García-Pablos de Molina, em obra organizada por Luiz Flávio Gomes: ‘O que Jakobs denomina de Direito Penal do inimigo, como bem sublinhou Cancio Meliá (Derecho penal del enemigo, cit., p. 59 e ss), nada mais é que um conjunto normativo que retrata uma nova modal, que pune o sujeito pelo que ele 'é' (criminoso habitual, profissional, organizado, que refuta a legitimidade do ordenamento jurídico de modo permanente), não pelo que fez; cuida-se de um direito que faz oposição ao Direito Penal do fato, que pune o agente pelo que ele 'fez' (não pelo que 'é', ou pelo que ele pensa etc.)' (Direito Penal v.1 Introdução e princípios fundamentais, Coordenação Luiz Flávio Gomes, RT, $1^{\text {a }}$ ed., p. 299)”“335.

De outro lado, aquela mesma $16^{\mathrm{a}}$ Col. Câmara, julgando Apelação Criminal interposta pelo Ministério Público com a finalidade de majorar a pena aplicada pelo Tribunal do Júri de Diadema/SP, deu provimento ao recurso e considerou para a exasperação da sanção — com base na personalidade do agente - fatos posteriores ao cometimento delito ${ }^{436}$ :

“(...) Da análise dos autos, constata-se que restou comprovado ter o apelado 'personalidade' que comporta maior grau de reprovação, diante do fato frisado pelo próprio Juízo de que quando preso pelo delito destes autos, constrangeu detento com o qual coabitava na cela e foi ao Fórum em seu lugar, vindo a ser libertado por engano, evadindo-se do distrito da culpa, foragido que está até hoje. Também revela o apelado 'personalidade' merecedora de maior reprovação por ter, após a prática do homicídio, ameaçado os familiares da vítima” ${ }^{437}$.

Como se pode constatar dos exemplos destacados, a aferição da personalidade por meio da avaliação do comportamento do acusado, seu modo de ser e de comportar-se, na maior parte das vezes, conta com uma análise personalíssima do magistrado, que enxerga o fato e os elementos comportamentais manifestados pelo réu segundo sua própria formação

\footnotetext{
435 Trecho extraído do v. acórdão de nº 2012.0000002213, p. 7.

${ }^{436} \mathrm{O}$ julgamento de ambos os recursos ocorreu na mesma data, 10.01.12.

${ }^{437} \mathrm{O}$ acórdão elevou a pena-base em 1/5, fixando-a definitivamente em 7 (sete) anos, 2 (dois) meses e 12 (doze) dias, fixando, ainda, o regime inicial fechado para cumprimento. Segundo o d. relator, não apenas a quantidade de pena deve servir de fundamento para a fixação do regime, mas também outras circunstâncias, no caso, a reincidência, a despeito de ter anotado expressamente estarem “ausentes agravantes (...)" (destacamos). TJSP, 16 a Câmara Criminal, AC 300322-45.1998.8.26..0161, Rel. Newton Neves, j. 10.01.12.
} 
ética e moral. Ademais, constata-se que tais elementos ou características do agente, em sua maioria, encontram-se dissociados do fato praticado.

Quanto à avaliação de fatos e comportamentos posteriores ao delito como critérios materiais de aferição da personalidade é possível afirmar que tal recurso mostra-se ainda mais temeroso e reprovável do que a consideração de fatos ou comportamentos anteriores ou da análise dos antecedentes criminais do réu, porquanto completamente dissociados do fato. Este último recurso, conforme se verá a seguir, ainda é recorrentemente utilizado pela jurisprudência como critério de avaliação da personalidade.

\subsubsection{Personalidade e antecedentes}

É farta a jurisprudência que admite a consideração dos antecedentes criminais como critério de avaliação da personalidade "voltada para o crime” e, nessa medida, como fundamento do aumento de pena. Dentre inúmeros julgados, colhem-se dos Tribunais Superiores os seguintes precedentes:

\footnotetext{
"(...) Ainda quanto não se possam considerar como antecedentes os atos infracionais praticados pelo menor, tratando-se de réu dotado de personalidade especificamente voltada para o crime, com base, inclusive, na multiplicidade desses atos, pode caracterizar-se a circunstância judicial da má personalidade do agente a justificar o aumento da pena-base” (STF, Rel. Moreira Alves, j. 11.12.98, RT 764/499)”.

"Inexiste constrangimento ilegal na fixação da pena-base pouco acima do mínimo legal quando se constata que as circunstâncias judiciais do réu não eram favoráveis. Ademais, é lícito ao Juiz reconhecer a existência de maus antecedentes e personalidade distorcida e afeita ao crime para a fixação da penabase além do mínimo legal e, ainda, seu agravamento pela reincidência, quando o acusado ostenta folha penal extensa, com várias condenações transitadas em julgado e, ainda, processos em andamento. Recurso desprovido." (STJ, RHC 13909/RJ, $5^{a}$ Turma, Rel. Min. Jorge Scartezzini, DJU 29.09.03).
}

Ainda no mesmo sentido, dos Tribunais Regionais das $4^{\mathrm{a}}$ e $5^{\mathrm{a}}$ Regiões, os seguintes exemplos: 
“Para a aplicação da pena no tocante à personalidade (maneira de sentir e agir relativa ao caráter do agente) não é necessária a análise de dados psicológicos, antropológicos e psiquiátricos do Apelante. É suficiente que, da análise dos autos, o Julgador constate que o Agente é contumaz na prática delituosa, aplicando golpes de forma reiterada, o que revela a personalidade voltada para o crime; e isto apenas pode ser constatado se ele confessar voluntariamente sua condição de criminoso contumaz, o que ocorreu no caso sob exame interrogatório de fls. 103/104- ou mediante a análise dos respectivos antecedentes criminais” (TRF5 ${ }^{\mathrm{a}} \mathrm{R}$, AC 2007.83.00.020810-9, Rel. Geraldo Apoliano, j.23.04.09).

“(...) 3. Desde que não sejam tomados como parâmetro os mesmos fatos delitivos, não há irregularidade alguma em considerar os diversos crimes constantes na folha corrida do meliante na aferição dos antecedentes, da personalidade e da reincidência.(...)" (TRF4 ${ }^{\mathrm{a}}$, AC 2001.04.01.085243-1, $8^{\mathrm{a}}$ Turma, Relator Des. Federal Luiz Fernando Wowk Penteado, DJU 23.06.04)

“(...) Havendo nos autos notícias de que o condenado responde a inquéritos policiais e ações penais por diversos crimes, em várias cidades e na Justiça Federal e Estadual, revela-se oportuna a remessa de cópia de acórdão que confirmou sentença condenatória às Autoridades Judiciárias, a fim de que possam bem avaliar a sua personalidade(...)" (TRF4ªR, AC 2000.04.01.0564410, $7^{\mathrm{a}}$ Turma, Relator Des. Federal Vladimir Freitas, DJU 25.06.02).

Tal entendimento, além de ferir o princípio da presunção de inocência, em se tratando de inquéritos ou processos em andamento, viola igualmente a proibição de bis in idem, já que o artigo 59, do CP, prevê dentre as circunstâncias judiciais também especificamente os “antecedentes” do réu.

De outro lado, parte do pressuposto de que o réu "conduz sua vida na criminalidade" de forma voluntária, desprezando o fato de as circunstâncias pessoais e ambientais que envolveram a formação de sua personalidade também merecerem consideração como elementos que eventualmente tenham influenciado seu entendimento e a formação de sua vontade $\mathrm{e}^{438}$. ${ }^{438}$ Nesse sentido, julgado do Tribunal de Justiça de São Paulo que negou pedido do Ministério Público de
aumento de pena em razão da "má personalidade" do agente. O relator do acórdão ponderou que a
personalidade deve ser aferida pelas condições pessoais de vida do agente e, nesse âmbito, considerou que as 
O Superior Tribunal de Justiça, consolidando reiterado entendimento, editou a Súmula 444, vedando a utilização de inquéritos policiais e ações penais em curso para agravar a pena base. O entendimento da Corte Superior já vinha se consolidando também no mesmo sentido com respeito ao critério da personalidade. Em reiterados julgados daquele Tribunal Superior encontram-se decisões, afirmando a impossibilidade de serem os antecedentes considerados como critério material de avaliação da personalidade e, nessa medida, como fundamento de exasperação da pena:

\footnotetext{
“(...) Ora, se é pacífica a compreensão desta Corte no sentido de que inquéritos e ações penais em curso não podem ser considerados para se firmar um juízo negativo sobre os antecedentes do acusado, o mesmo raciocínio deve ser adotado relativamente à circunstância personalidade, pois se não o são para a circunstância que lhes é própria, ainda com mais razão não poderiam ser para matéria que não é pertinente ao exame da matéria”439.
}

Com base no entendimento firmado pelo Superior Tribunal de Justiça, compreendemos que os antecedentes criminais não podem servir como critério de avaliação da personalidade, especialmente com o fim de justificar seu aumento, ultrapassando a medida da culpabilidade. Em primeiro lugar, porque tal entendimento alinha-se à vertente da culpabilidade pela condução de vida ou pela formação da personalidade, que rechaçamos desde o princípio. De outro lado, porque fere o princípio da presunção de inocência, motivo pelo qual a própria circunstância “antecedentes”, prevista na redação do artigo 59, do CP, mereceria questionamento próprio sobre sua legitimidade como circunstância judicial a ser sopesada no processo de dosimetria da pena.

\subsubsection{Outros critérios}

dificuldades de vida sofridas pelo acusado denotam que sua personalidade é reflexo dos problemas que enfrenta no cotidiano. Não o fez a ponto de reduzir a pena fixada, nem para justificar o comportamento criminoso, mas de modo a demonstrar que a personalidade assume o significado de um conjunto de circunstâncias pessoais que devem ser consideradas para a análise da circunstância judicial: “(...) Ora, saltam aos olhos, in casu, as dificuldades pelas quais passa o réu-apelante em seu dia a dia (...) Nada evidentemente, a justificar o seu comportamento criminoso. Denota-se, no entanto, que sua personalidade é reflexo dos problemas que enfrenta no cotidiano” (TJSP, AC 344.364/3, Rel. Jarbas Mazzoni, j. 01.04.02).

439 HC 174.760/MG, Rel. Min. Maria Thereza de Assis Moura, DJe 19.09.11. No mesmo sentido: HC 116901/SP, Rel. Min. Maria Thereza de Assis Moura, DJe 22.06.11; HC 103020/DF, Rel. Min. Jorge Mussi, DJe 03.08.09; HC 90630/DF, Rel. Min. Jane Silva (desembargadora convocada do TJ/MG), DJ 12.11.07; REsp 930376/RS, Rel. Min. Felix Fischer, DJe 03.08.09, dentre outros. 
Colhe-se da jurisprudência outros tantos critérios para avaliação da personalidade que, a exemplo dos demais, não necessariamente estão vinculados ao fato praticado.

Os motivos do crime, embora constituam circunstância judicial autônoma no artigo 59 do Código Penal, recorrentemente são tomados pela jurisprudência como critério de avaliação da personalidade. Nos crimes de tráfico de entorpecentes, não raro encontram-se julgados relacionando a quantidade de droga ao grau de "periculosidade" do agente, utilizando-se desse critério para avaliação da personalidade do réu ${ }^{440}$.

No exemplo abaixo destacado, é possível constatar a carência de critérios seguros para aferição da personalidade. Fatores como o fato do réu ser "desocupado", estar foragido da Justiça, dentre “tantos outros fatores” denotam a falta de racionalidade quanto à eleição dos critérios de avaliação do critério da personalidade, bem como escancaram o fato de que, em última instância, qualquer elemento da vida do acusado pode ser tomado negativamente com a finalidade de aumentar a pena, se assim entender razoável o magistrado sentenciante:

\footnotetext{
"Em relação ao art. 12, atento aos ditames do art. 59 do CP, observadas as circunstâncias, o local dos fatos, a culpabilidade do agente, aquele que desrespeita as leis de maneira reiteradas, possuindo condenação criminal grave e outros processos, uma recente pena por tráfico de drogas em outra comarca(fls. 352), ações policiais e judiciais, essas que não serviram como retribuição, nem para fins de prevenção e ressocialização do incorrigível réu, ele que demonstra personalidade intensamente tendente para o mundo do crime, o fato de ser desocupado a pretexto de borracheiro, estando foragido da Justiça, com três ordens de prisão diferentes, todas por tráfico de drogas, dentre tantos outros fatores, fixo a pena base acima do mínimo legal observados os parâmetros legais entre 3 e 15 anos de reclusão, em 6 anos de reclusão e 100 dias-multa”" ${ }^{441}$.
}

\footnotetext{
440 Nestes dois sentidos, o já mencionado acórdão do Tribunal de Justiça do Rio Grande do Sul (AC70022258867, Rel. Marco Aurélio de Oliveira Canosa, j. 13.08.09.: "A personalidade apresenta-se deformada. Há circunstâncias que permitem tal conclusão. Com efeito, o móvel do delito - lucro fácil em detrimento da saúde pública - está a indicar nota-anti-social. Lembra-se, neste passo, a lição do mestre HUNGRIA. Além disso, a quantidade da droga esta a apontar para o grau de envolvimento do infrator com o odioso comércio, indicando a medida de sua personalidade perigosa e voltada para a prática criminosa". ${ }^{441}$ TJSP, HC 345.658-3, Rel. Marcos Zanuzzi, j. 16.05.01.
} 
De fato, a jurisprudência majoritária entende que a personalidade deve ser aferida pelo juiz sem tecnicismo, prescindindo de qualquer rigor científico. Nesse sentido, julgado do Tribunal Regional da $4^{\text {a }}$ Região, de cujo voto condutor extraem-se os seguintes trechos:

“Com a devida vênia aos que pensam o contrário, entendo que a vetorial da 'personalidade do agente' prescinde do rigor científico preconizado no voto vencido, havendo, por conseguinte, a possibilidade de o operador do Direito chegar a uma conclusão adequada no campo da dosimetria da pena por meio de determinadas manifestações comportamentais do denunciado que reflitam algum desvirtuamento em seu caráter. Formulo meu posicionamento com fundamento em uma interpretação teleológica e também sistemática do termo 'personalidade do agente' enquanto determinante legal da pena-base. Sob o prisma finalístico, descabido imaginar que ao incluir a presente circunstância judicial dentre os elementos quantitativos da sanção penal o legislador criminal pressupunha contar com um nível de conhecimento psicológico, médico e antropológico dos magistrados capaz de delimitar, com precisão científica, a precisa amplitude da expressão 'personalidade’. De fato, consabido que em nosso país os currículos dos cursos universitários destinados à formação jurídica abrangem, quando muito, algumas disciplinas referentes à criminologia e à medicina legal. Todavia, a profundidade com que tais assuntos são abordados nos bancos acadêmicos está longe de permitir a interpretação utópica de que o legislador penal contava, ao estabelecer a vetorial da 'personalidade do agente', com uma formação acurada dos aplicadores da lei a respeito das variadas particularidades de ordem psicológica, social, comportamental e até mesmo patológica que permeiam uma definição rigorosa da personalidade do indivíduo. A opinião dos doutrinadores criminalistas reforça o entendimento de que a 'personalidade do agente' consiste numa vetorial dirigida aos juízes, advogados, promotores e demais operadores do Direito, sem desconsiderar a condição de ‘homem-médio’ dos mesmos em áreas do conhecimento não afeitas à ciência jurídica. (...) exige-se que o magistrado avalie o comportamento do acusado a partir daquelas manifestações $\underline{\text { de vontade }}$ cotidianas da pessoa, aptas a informarem o grau de importância e respeito conferido aos bens jurídicos tidos por mais valiosos à vida em comunidade. Em suma, pautado em um exame pragmático das relações sociais travadas pelo réu, compete ao julgador definir se o crime cometido representa um fato isolado na sua vida ou se significa mais uma expressão de um caráter mal formado que, além de não refletir sobre os efeitos socialmente negativos decorrentes dos seus atos, volta a produzi-los em flagrante expressão de seu modus vivendi. (...) Por fim, incabível supor que a falta de um parecer médico ou psicológico para 
constatação da 'personalidade do agente' viole a garantia constitucional da individualização da pena, porquanto a própria Carta Magna remete à regulamentação legislativa - Código Penal - o procedimento de dosimetria das reprimendas.” $^{442}$.

Os argumentos colhidos do julgado acima destacado possibilitam entender as razões pelas quais, na prática jurisprudencial, constata-se, com alarmante frequência, a aferição da personalidade com base em critérios imprecisos, selecionados de acordo com a sensibilidade do magistrado, o que se justifica, segundo tais argumentos, na desnecessidade de se conferir à análise da personalidade um caráter científico.

Com vistas nos dados levantados na doutrina e colhidos da jurisprudência a respeito da personalidade como critério de fixação judicial da pena, cabe, a seguir, tecer alguns argumentos a respeito de sua legitimidade como critério judicial de fixação judicial da sanção.

\subsection{Legitimidade da consideração da personalidade como critério judicial de individualização da pena}

Vários e relevantes são os argumentos em defesa da ilegitimidade dessa circunstância que merecem ser destacados. De fato, a mera presença do critério da personalidade dentre o rol de circunstâncias judiciais elencados no Código Penal não constitui argumento suficiente para afirmar a sua recepção pela Constituição Federal.

Do ponto de vista processual, tomada em conta a vagueza do conceito de personalidade, já ressaltada nos itens anteriores, assim como a fluidez dos critérios materiais com que a jurisprudência a avalia, é forçoso concluir, com reforço no pensamento de Salo de Carvalho, que dito critério "não apresenta, desde o modelo acusatório, possibilidade de verificabilidade processual pelo magistrado e pelas partes ${ }^{443}$.

De fato, como bem ressalta o autor, para poder fundamentar o juízo sobre a personalidade do réu, o juiz deveria indicar qual o conceito de personalidade em que se 
baseou para a tarefa, qual a metodologia utilizada, quais os critérios que seguiu e em qual momento processual foi-lhe possibilitada sua averiguação ${ }^{444}$. É nesse sentido que conclui que "não basta, pois, o magistrado suscitar um elemento categórico, encobrindo-o por termos vagos e imprecisos. O requisito constitucional da fundamentação das decisões impõe a explicitação dos critérios, métodos e conceitos utilizados” ${ }^{445}$.

Parece-nos inquestionável a impossibilidade de refutação do fundamento do critério da personalidade por parte do acusado. Como bem salienta o já mencionado autor, “(...) $a$ noção de personalidade auferida pelos magistrados padece de profunda anemia significativa, conformando o substrato de decisões infundadas, sem o mínimo controle técnico, ferindo, pois, o princípio da ampla defesa e da estrita jurisdicionalidade” ${ }^{446}$. Como consequência, acaba-se impondo ao acusado o cerceamento de sua defesa processual, especialmente no que toca à possibilidade de discutir, em outras instâncias, os fundamentos racionais utilizados pela sentença condenatória que fundamentou a imposição da pena com base nesse critério.

De outro lado, é irrefutável a falta de preparo técnico do magistrado para operar com o conceito de personalidade na prática judiciária.

José Pagnella Boschi argumenta que nem tanto a falta de preparo técnico dos juízes para a avaliação da personalidade do réu representa o maior problema relacionado ao tema, mas, sim, a própria legitimidade do critério da personalidade como circunstância judicial.

Na linha do que vimos defendendo, o autor questiona qual a justificativa para a invasão discricionária pelo Estado na esfera de intimidade da pessoa. E, aqui, retomam-se os temas da culpabilidade e da legitimidade da sanção aplicada com fundamento nos aspectos subjetivos do réu, ainda que supostamente tenham se exteriorizado no fato:

\footnotetext{
“Ora, os indivíduos devem ser punidos pelos atos ilegais que praticarem, e não pelo que são ou pensam que são, para não termos que renegar a evolução do
}

\footnotetext{
${ }^{444}$ Cf. DE CARVALHO, Salo. Ibidem, p. 55.

${ }^{445}$ Idem, ibidem, p. 56.

${ }^{446}$ Idem, ibidem, p. 57.
} 
direito penal e retornarmos ao medievo, cujos tribunais os executavam porque pensavam, e não porque haviam feito algo" ${ }^{447}$.

A jurisprudência também diverge quanto à legitimidade da personalidade do agente como circunstância judicial, especialmente como fundamento de exasperação da sanção.

De um lado, encontram-se argumentos que correspondem ao entendimento tradicional de nossa doutrina, afirmando a legitimidade da análise da personalidade pelo juiz, de acordo com os mais variados critérios materiais de aferição. De outro, já se encontram julgados críticos, afirmando a inconstitucionalidade da avaliação da personalidade.

A título de exemplo, colhem-se do mesmo Tribunal de Justiça do Rio Grande do Sul julgados, defendendo os dois entendimentos.

Em acórdão proferido pela $2^{a}$ Câmara Criminal, o TJRS reformou sentença que afastava a avaliação da personalidade como fundamento da majoração da pena-base por entender que tal circunstância, tal como a conduta social, "tão-somente se prestam a favorecer o acusado, jamais para asseverar-lhe a pena. Trata-se da adoção do princípio da secularização, do qual impende a observância da separação entre o direito e a moral”, ressaltando que “os juízes não estão tecnicamente habilitados a perquirir sobre questões de personalidade, mormente quando o caderno processual não oferece elemento algum a esse respeito" ${ }^{448 .}$.

O Tribunal, no entanto, reformou a sentença, provendo o recurso do Ministério Público para afastar a pena do mínimo legal. Dentre outros argumentos, o fundamento do v. acórdão baseou-se na análise da personalidade do acusado, sob os seguintes fundamentos:

\footnotetext{
${ }^{447}$ BOSCHI, José Antonio Pagnella. Das penas e seus critérios de aferiação, p. 175. Também nesse sentido Salo de Carvalho adverte: “(...) mesmo que o magistrado fosse apto a realizar tal tarefa, o juízo sobre a personalidade do sujeito seria ilegítimo, visto estar assentado em valoração estritamente moral sobre o 'ser' do acusado. A propósito, esta é a indicação presente na dogmática tradicional. (...) A questão que se coloca repetimos, não é nem se existem ou não condições mínimas de o julgador estabelecer este juízo, cuja resposta já afirmamos negativamente dada a deficiente formação (trans) disciplinar do operador jurídico. $O$ problema que levantamos é que, mesmo que houvesse condições, esta avaliação seria ilegítima sob o prisma de um direito penal balizado pelo princípio da secularização”. Op. cit., p. 59.

${ }^{448}$ Trecho da sentença relatado pelo v. acórdão do TJRS, $2^{\mathrm{a}}$ Câmara Criminal, AC 70022258867, Rel. Marco Aurelio de Oliveira Canosa, j. 13.08.09.
} 
“A personalidade apresenta-se deformada. Há circunstâncias que permitem tal conclusão. Com efeito, o móvel do delito - lucro fácil em detrimento da saúde pública - está a indicar nota anti-social. Lembra-se, neste passo, a lição do mestre Hungria (Comentários ao Código Penal, volume V, Forense, 1981): ‘Os motivos determinantes constituem, no direito penal moderno, a pedra de toque do crime. Não há crime gratuito ou sem motivo e é no motivo que reside a significação mesma do crime. O motivo é o “adjetivo” do elemento moral do crime. É através do 'porquê' do crime, principalmente, que se pode rastrear a personalidade do criminoso, e identificar a sua maior ou menor antisociabilidade’ (fls. 123). Além disso, a quantidade da droga esta a apontar 'para o grau de envolvimento do infrator com o odioso comércio, indicando a medida de sua personalidade perigosa e voltada para a prática criminosa’ (passagem da ementa do HC 18940/RJ, Relator: Ministro José Arnaldo da Fonseca, Órgão Julgador: Quinta Turma; Data do Julgamento: 05/03/2002)”.

Noutra oportunidade, o mesmo Tribunal de Justiça, por sua $7^{\mathrm{a}}$ Câmara Criminal, afirmou a inconstitucionalidade da análise de personalidade por violar a garantia constitucional da liberdade individual, o princípio da secularização e o princípio da taxatividade penal — segundo o qual só será punível a conduta taxativamente prevista como crime pelo ordenamento jurídico. Do brilhante voto de lavra do Des. Sylvio Baptista Neto colhem-se os principais fundamentos para o provimento do recurso e redução da pena-base:

“A punição tem que levar em conta a culpabilidade, os antecedentes, os motivos, as circunstâncias e consequências do crime. Excepcionalmente, minorando-a face à boa conduta e/ou a boa personalidade do agente. Em primeiro lugar, tal posição decorre da garantia constitucional da liberdade, prevista no artigo $5^{\circ}$ da Constituição Federal. Se é assegurado ao cidadão apresentar qualquer comportamento (liberdade individual), só responderá por ele, se a sua conduta (lato senso) for ilícita. Ainda que sua personalidade ou conduta social não se enquadrem no pensamento médio da sociedade em que vive, mas seus atos são legais, elas não podem ser utilizadas para o efeito de aumentar sua pena, prejudicando-o. (...) O rompimento dos vínculos entre direito e moral passa a ser conditio sine qua non na formação dos modelos constitucionais (garantistas) de direito penal e de direito processual penal. Diferentemente do pensador porteño, entendemos estar o princípio da secularização incorporado na Constituição 
Federal de 1988, não consistindo apenas uma meta-garantia, mas uma garantia positivada sob o signo dos princípios da inviolabilidade da intimidade e do respeito à vida privada $\left(\operatorname{art} .5^{\circ}, \mathrm{X}\right)$, do resguardo da liberdade de manifestação de pensamento (art. $5^{\circ}, \mathrm{IV}$ ), da liberdade de consciência e crença religiosa (art. $5^{\circ}$, VI), da liberdade de convicção filosófica ou política (art. $5^{\circ}$, VIII), da garantia de livre manifestação do pensar (art. 5º IX), do direito de reunião (art. 5º, XVI) e do direito de associação (art. 50, XVII e XVIII). Ferrajoli (Ferrajoli, Diritto e ragione: teoria del garantismo penal, p. 207/09) sustenta que a adoção do princípio da secularização implica três conseqüências axiológicas ao direito penal e processual penal. Em relação ao delito estabelece que o direito penal deve apenas impedir condutas danosas (dano concreto) para terceiros. Quanto ao processo e à jurisdição, exige que o juízo não verse sobre a moralidade, caráter ou outros aspectos substanciais da personalidade do réu, mas somente acerca dos fatos penalmente proibidos que lhes são imputados e que podem, por outra parte, ser empiricamente provados pela acusação e refutados pela defesa. Quanto à pena e seu modo de execução, o princípio limita a sanção penal em não poder adquirir conteúdo ou fim moral. Assim, '(...) a interioridade de uma pessoa - o seu caráter, a sua moralidade, os seus antecedentes criminais, as suas inclinações psicofísicas - não deve interessar ao Direito Penal senão para deduzir o grau de culpabilidade de suas ações. Se entende que não existe espaço, em um sistema garantista assim configurado, para categorias de periculosidade nem qualquer outra tipologia subjetivista ou de autor elaborada pela criminologia antropológica e eticista, como capacidade criminal, reincidência, tendências criminosas, imoralidade, infidelidade e similares’ (Ferrajoli, op. cit., p. 505).As normas que estatuem juízos subjetivados sobre o autor, como a reincidência, são normas penais constitutivas, i.e., normas que não vetam condutas lesivas, mas que castigam imediatamente; normas que não proíbem atuar, mas ser. São normas que configuram hipóteses de desvio que não consistem necessariamente fatos e que carecem do elemento materialidade, como normalmente são as figuras de perigo social (hediondos, perigosos, vagabundos, subversivos, hereges et coetera).” (Jurisprudência Comentada, Revista da Ajuris, vol. II (nova série), págs. 750/755)”449.

Prosseguindo, o D. relator ressaltou que a indefinição do conceito de personalidade, como vimos afirmando desde o princípio, constitui fator de insegurança jurídica e viola o princípio da legalidade, tratando-se de um processo que resulta da impressão pessoal do operador do Direito:

${ }^{449}$ TJRS, 7ª Câmara Criminal, AC 7003735268, Rel. Sylvio Baptista Neto, j. 29.07.10. 
“(...) Em primeiro lugar, a conceituação do 'mau sujeito', familiar e socialmente, repito, é muito vago. Eu até diria: extremamente vago. O que significa 'um mau pai, um mau marido, mau filho, mau vizinho, mau colega, mau companheiro etc.'? Se algumas situações são fáceis de enquadrar nos conceitos anteriores, outras tantas não o são. A configuração fica na dependência de variantes, de condicionantes dos juízes, dos promotores, defensores etc. De mentes influenciadas pelo passado, pela educação, pelos traumas etc. Determinado comportamento pode ser irrelevante para um juiz, mas não para outro, que o considera grave. É improvável que se encontre duas pessoas que coincidam no pensamento do que seria má ou boa personalidade, má ou boa conduta social, baseando-se em aspectos familiar e social do acusado. Esta indefinição fere de morte o princípio da legalidade, pois as margens do apenamento tornam-se muito elásticas, impossibilitando determinar o quantum aplicável ao condenado. Lembro que, no sistema trifásico, as circunstâncias do art. 59 do CP têm grande influência na pena-base, criando uma incerteza para o acusado sobre o tempo de privação de sua liberdade. Em segundo lugar, volto ao início de meu voto, onde afirmo que é assegurado ao cidadão ter qualquer comportamento, respondendo penalmente por ele, apenas se a conduta for ilícita. O que importa ao Direito Penal ou mais precisamente para a imposição de uma pena justa (necessária e suficiente para a reprovação e prevenção do crime), o fato do réu não conviver com os filhos ou com os pais (mau pai ou filho), atrasar seus compromissos (mau devedor), não compartilhar os trabalhos comunitários (mau vizinho, mau cidadão) etc.? São atitudes reprováveis, mas permitidas pela Constituição. Dirse-á que ele não é uma boa pessoa (personalidade), tem uma má conduta social. Porém isto não pode ter nenhuma influência no momento da punição, pois tais comportamentos fazem parte de algo maior, mais importante democraticamente, que é a liberdade individual. Ele tem o direito de usá-la (liberdade de pensamento e de comportamento) erradamente, desde que não de forma ilícita. Portanto, insisto, utilizar a personalidade e a conduta social, para agravar a pena, fere as garantias constitucionais da liberdade e legalidade. É ilegal aumentar a punição do agente em um, dois, três etc., meses, porque o réu ‘não é bom’ ” .

Nesse mesmo sentido, o Superior Tribunal de Justiça vem se manifestando criticamente quanto à própria legitimidade da personalidade como critério de fixação da pena, afirmando sua impossibilidade de aferição no caso concreto, sobretudo, como 
fundamento de aumento da sanção, bem como a falta de preparo técnico dos juízes para seu manejo:

\begin{abstract}
“A pena-base foi majorada, dentre outras, com base na personalidade do agente. Ocorre que é lamentável que a personalidade ainda conste do rol das circunstâncias judiciais do art. 59, do CP, pois se trata, na verdade, de resquício do Direito Penal de Autor. Além do mais, dificilmente constam dos autos elementos suficientes para que o julgador (que, de regra, não é psiquiatra e nem psicólogo - não sendo, portanto, expert) possa chegar a uma conclusão cientificamente sustentável. Por conseguinte, não havendo dados suficientes para a aferição da personalidade do agente, mostra-se incorreta sua valoração negativa a fim de supedanear o aumento da pena-base" ${ }^{450}$.
\end{abstract}

Em conclusão, entendemos que o critério da personalidade, por não contar com uma definição pacificada do ponto de vista dogmático, por ser aferida por meio de critérios materiais diversos — na maior parte das vezes, inconsistentes - e, sobretudo, por ser um elemento da subjetividade do acusado, não tem legitimidade para fixar a pena acima do limite da culpabilidade e da proporcionalidade com o fato. Contudo, a depender das circunstâncias do caso concreto, se sua aferição mostrar-se fundamentada em elementos refutáveis pelas partes, poderá, eventualmente, servir para atenuar a sanção.

Concluímos, com respaldo no pensamento de Franciso de Assis Toledo:

\begin{abstract}
"Embora o direito penal esteja chamado a fortalecer a ordem moral, sob pena de incorrer em erro oposto (mas não menos grave) do da corrente que pretendeu reduzi-lo às ciências auxiliares, não pode ter pretensões de transformar-se em uma espécie de 'teologia moral’. Se o fizer, não alcançará a grandiosidade de uma autêntica teologia moral e perderá seu limitado sentido pragmático de proteção de vida comunitária do homem na sociedade, mediante a tutela de determinados bens jurídicos (...) Um direito penal que pretenda modelar o homem correrá o risco de cair na indigência, com todo o seu excesso de penas, para usar uma imagem de Welzel. Não pode, pois, ter pretensões de modelar, sob
\end{abstract}

${ }^{450}$ STJ, HC 136.685, Rel. Min. Felix Fischer, DJe 07.12.09. No mesmo sentido, de mesma relatoria, os seguintes precedentes da Corte Superior: RESP 745530/RS, DJU 12.06.06; RESP 732857/RS, , DJU 12.12.05. 
cominação de pena, o 'ser existencial' do homem. Essa missão não lhe compete" $^{451}$.

\section{5. “Condições pessoais do réu”: uma significação restritiva possível}

\subsubsection{O modelo espanhol}

O termo “circunstâncias pessoais do réu” foi introduzido no Código Penal espanhol em 1995, em substituição ao termo "personalidade do agente" (antes contido no art, 61.41C do Código Penal de 1973) ${ }^{452}$. A atual redação do artigo vem assim estabelecida:

\footnotetext{
Artículo 66: 1. En la aplicación de la pena, tratándose de delitos dolosos, los Jueces o Tribunales observarán, según haya o no circunstancias atenuantes o agravantes, las siguientes reglas (...)

$6^{a}$. Cuando no concurran atenuantes ni agravantes aplicarán la pena establecida por la Ley para el delito cometido, en la extensión que estimen adecuada, en atención a las circunstancias personales del delincuente y a la mayor o menor gravedad del hecho.
}

Em todas as previsões em que o termo é empregado na legislação penal espanhola, a expressão legal supõe, necessariamente, um juízo valorativo associado à pessoa do sujeito.

Martín Besio Hernádez afirma que não existe absoluta clareza na dogmática penal espanhola acerca do sentido normativo específico e o conteúdo concreto que cabe atribuir à cláusula geral “circunstâncias pessoais do delinquente”, em que pese seja possível constatar alguns consensos gerais.

Duas são as aproximações dogmáticas que aponta em referência ao seu significado jurídico-penal: a primeira, majoritária, entende que dita cláusula incorpora explicitamente uma referência direta ao fim preventivo-especial na fase de individualização da pena. A segunda tendência doutrinal alinha-se no sentido de entender que a referência legislativa às

451 TOLEDO, Franciso de Assis. Op. cit., p. 247.

${ }^{452}$ Cf. BESIO, Martín Hernandez. Op. cit., p.405. 
circunstâncias pessoais do autor importa uma alusão não já diretamente ou unicamente a fins preventivo-especiais, senão que a outros tipos de considerações político-criminais ou dogmáticas, como a categoria da culpabilidade.

Seja qual for a posição adotada, afirma, mantém-se, de todas as formas, a indeterminação de seu conteúdo específico, pois o próprio sentido da prevenção especial como fim do Direito Penal é controvertido e, ademais, a referência legal às circunstâncias pessoais do delinquente constitui, para ele, uma expressão demasiadamente genérica e abstrata que é necessário aterrissar por meio de critérios concretos de valoração, uma vez que o próprio legislador não apontou as circunstâncias ou elementos que devem ser considerados para sua aferição ${ }^{453}$.

Por essa razão, o autor entende que o sentido a ser dado à clausula das circunstâncias pessoais do autor dependerá do sentido específico que cabe atribuir à função preventivo-especial na determinação da pena ${ }^{454}$.

Partindo do sentido de prevenção especial positiva já apontado anteriormente e, afastando qualquer possibilidade de consideração das circunstâncias pessoais para aferição de um juízo de perigosidade do agente, o autor espanhol admite a análise das circunstâncias pessoais do autor como critério para fundar exclusivamente a diminuição da magnitude da pena.

Mas adverte que a cláusula das circunstâncias pessoais do delinquente constitui uma estrutura aberta que permitiria abranger uma série de elementos de referência de ponderação do objetivo preventivo-especial. O problema surge, segundo ele, a partir da concreção de tais parâmetros ao caso particular e à hora de justificar (ou legitimar) por eles uma decisão de aumento da condenação sobre a base da perigosidade que, em ditos critérios, estariam destinados a avaliar.

\footnotetext{
453 Já Demetrio Crespo entende que a expressão “circunstâncias pessoais do delinquente” é mais ampla. Para o autor, a nova expressão comporta tanto a personalidade como outra série de fatores. Nesse ponto, o autor entende que a nova expressão do CP reduz o arbítrio do juiz, pois o obriga a tomar em consideração um maior número de questões. Análisis de los criterios de la individualización judicial de la pena en el nuevo código penal español de 1995, p. 346.

${ }^{454}$ BESIO, Martín Hernandez, Op. cit., p. 409-410.
} 
É nesse sentido que alerta para o risco de boa parte dos parâmetros pessoais (como por exemplo: o baixo grau de instrução, sua estrutura familiar, etc.) serem suscetíveis de fundamentar tanto um aumento como uma diminuição da pena: sempre será possível argumentar num ou noutro sentido, utilizando-se o mesmo parâmetro "objetivo", o que importa que, ao final das contas, a decisão dependerá inevitavelmente da subjetividade do intérprete ${ }^{455}$.

Para o autor, o argumento definitivo encontra-se na ilegitimidade de utilização desses parâmetros para aumentar a quantidade da pena, isto é, o seu manejo em prejuízo do acusado, pois se tratam de aspectos que não guardam relação nenhuma com o fato executado: o único que o Direito Penal pretende e pode prevenir licitamente.

A respeito da ponderação das circunstâncias pessoais do delinquente por meio do fato delitivo, o autor reconhece uma certa tendência na jurisprudência espanhola de vincular diretamente a valoração de ditas circunstâncias pessoais com o delito propriamente executado, extraindo a partir do fato uma prognose de periculosidade do delinquente, perdendo, por isso, autonomia a consideração de forma independente de suas circunstâncias pessoais.

Para o autor, a pretensão de avaliar a personalidade do delinquente à luz da forma de execução do delito, no sentido de se esta resulta ser mais ou menos reprovável, só resulta compatível com uma estrutura punitiva associada ao Direito Penal de autor e da culpabilidade pela forma de vida, que, no sentido que se vem argumentando, deve ser tida como inadmissível ${ }^{456}$.

Assim, assevera que, por serem fatores autônomos e distintos, o fator gravidade do fato e circunstâncias pessoais do réu devem ser valorados de forma independente e, por isso, as circunstâncias pessoais do réu não poderão modificar a gravidade do fato, e viceversa.

${ }^{455}$ Idem, ibidem, p. 422.
${ }^{456}$ Idem, ibidem, p. 433. 
Exemplificativamente, as condições familiares do réu poderão apontar uma contraindicação da pena privativa de liberdade, assim como a sensibilidade do autor à pena poderá contraindicar, por razões de humanidade, seu contato com o cárcere, em razão, por exemplo, de uma enfermidade terminal ${ }^{457}$.

O mesmo se pode argumentar quanto aos antecedentes criminais como critério real de aferição das circunstâncias pessoais do delinquente — cuja legitimidade como agravante vem sendo questionada por tendências recentes na dogmática espanhola. Os antecedentes deverão ser avaliados positivamente. Ou seja, a ausência de condenações penais anteriores poderia levar a uma diminuição da quantidade da pena, sob o fundamento de uma menor necessidade de prevenção especial, na medida em que, de um réu primário não há razões de se esperar o cometimento de novos delitos - ideia que está em consonância com uma explicação preventivo-especial razoável e, sobretudo, de acordo com a pretensão de não dessocialização do delinquente.

É nesse sentido que concluímos que a saída dogmática que se vislumbra como possível será substituir, a exemplo do Código Penal espanhol - e conforme já prevê o Projeto de Lei $\mathrm{n}^{\circ}$. 3.473/00 — o termo “personalidade”, poroso e de difícil aferição, pelo termo “condições pessoais" ${ }^{458}$, cuja aferição e manejo na individualização da pena deverá estar sempre relacionado a critérios objetivos relacionados ao autor (seu grau de educação, situação familiar, profissional e econômica, bem como ao grau de sensibilidade à pena) com vistas à não dessocialização do réu.

Entende-se que, dessa maneira, estará salvaguardado o princípio da proporcionalidade com o fato e a medida da culpabilidade, sem se desprezar por completo a figura do agente do delito, respeitados, ainda, os princípios próprios de um Direito Penal de Estado de Direito, em especial o direito à intimidade, à liberdade de pensamento e de expressão e os princípios da legalidade e da taxatividade.

\footnotetext{
${ }^{457}$ Idem, ibidem, loc. cit..

458 Optamos pela expressão “condições” em lugar do termo “circunstâncias”, previsto na legislação espanhola, não apenas em razão da previsão daquele termo no Projeto de Lei $n^{\circ}$. 3.473/00, mas porque sugere um significado mais relacionado àquilo que se impõe sobre a individualidade do sujeito, determinando seu estado e situação atual. Entendemos que o termo “condições pessoais” permite relacioná-lo com os mais diversos aspectos da vida do acusado: seu estado de saúde, sua condição social, econômica e profissional, sua formação escolar, estrutura familiar, grau de desenvolvimento cognitivo, etc.
} 


\section{CONCLUSÕES}

A partir do século XIX, a Ciência Penal viu-se invadida por um discurso subjetivista peculiar, próprio das ideologias de defesa social e do positivismo criminológico. Colaborou diretamente para esse processo a produção doutrinária dos membros da Escola Criminológica Positivista italiana. Tal discurso criou uma nova forma de se enxergar o crime e o criminoso e, especialmente, de dar resposta ao crime.

As mais diversas legislações penais influenciadas por essa tendência passaram a adotar o critério da "personalidade do delinquente" como elemento central no processo de aplicação da pena. No Brasil, da mesma forma, a doutrina penal reforçou esse entendimento, reproduzindo o discurso subjetivista que alcançou a prática judiciária e a própria produção legislativa: o conceito de periculosidade, a adoção da personalidade como principal critério para aplicação da pena, a adoção das medidas de segurança segundo o modelo do duplo binário, a classificação de criminosos e o maior apenamento de réus reincidentes são provas de que a legislação brasileira submeteu-se profundamente a esse processo de subjetivação.

A evolução do pensamento jurídico-penal brasileiro e as transformações na legislação brasileira não foram suficientes para fazer desaparecer o discurso subjetivista da ciência penal brasileira na atualidade. Permanece arraigada na nossa doutrina tradicional e na jurisprudência a visão subjetivista do processo de aplicação da pena, para o qual o critério da personalidade serve como porta aberta a um sem número de interpretações que, na maior parte das vezes, levam a um aumento de pena que supera a própria proporcionalidade com o fato praticado e a medida da culpabilidade.

As teorias que vêm sendo formuladas nas últimas três décadas em países como a Espanha e a Alemanha demonstram que o processo de determinação da pena necessita de maior racionalização entre a doutrina, com o especial fim de orientar a prática judiciária, evitando a prolação de decisões violadoras de direitos fundamentais. 
É necessário, para esse processo de racionalização, rever o conceito de culpabilidade para a medida da pena, afastando-se qualquer resquício de uma culpabilidade de autor. Da mesma forma, é necessário retirar a carga subjetivista contida no art. 59 do Código Penal, trazendo, para o processo de determinação da pena-base, elementos relacionados ao autor que não se refiram à sua subjetividade, mas sim à sua realidade palpável.

Para tanto, entende-se como uma saída possível a substituição do critério da personalidade pelo termo "condições pessoais do acusado", a exemplo do que ocorreu com o Código Penal espanhol e do que prevê o Projeto de Lei $\mathrm{n}^{\circ}$. 3.473/00, desde que manejado de acordo com a finalidade preventiva especial da pena, entendida como não dessocialização do réu. 


\section{BIBLIOGRAFIA}

Alcântara Machado e o novo Código Penal. Revista Penal e Penitenciária. São Paulo, Ano II, vol. II, fasc. 1/2, 1941.

ALVAREZ, Marcos César. Apontamentos para uma história da criminologia no Brasil. In: KOERNER, Andrei (Org.). História da justiça penal no Brasil: pesquisas e análises. São Paulo: IBCCRIM - Instituto Brasileiro de Ciências Criminais, 2006. v. 40. p. 129-151.

ANCEL, Marc. A Nova Defesa Social. Rio de Janeiro: Forense, 1979.

ANITUA, Gabriel Ignacio. Historias de los pensamentos criminologicos. Buenos Aires: Del Puerto, 2005.

BACIGALUPO ZAPATER, Enrique. A personalidade e a culpabilidade na medida da pena. Revista de Direito Penal, Rio de Janeiro, n. 15/16, jul./dez. 1.974.

Principio de culpabilidad e individualización de la pena. In: CEREZO MIR, José ... [et al]. El nuevo código penal: presupuestos y fundamentos: libro homenaje al professor doctor Don Ángel Torío López. Granada: Comares, p. 33-48, 1999.

BARBOSA, Ruy. A obra de Ruy Barbosa em criminologia e direito penal. Rio de Janeiro: Escola Nacional de Direito, 1952.

BETTIOL, Giuseppe. Direito Penal. Tradução de Paulo José da Costa Júnior e Alberto Silva Franco. São Paulo: Revista dos Tribunais, 1976.

Sobre o Direito Penal da atitude interior. Revista dos Tribunais. RT 442/1972, ago. 1972.

BOSCHI, José Antonio Paganella. Das penas e seus critérios de aplicação. Porto Alegre: Livraria do Advogado, 2000. 
BRUNO, Anibal. Direito Penal. Parte Geral. Rio de Janeiro: Forense, 1978.

A perigosidade criminal. Dissertação apresentada à Faculdade de Direito do Recife, 1937.

CASTIGLIONE, Theodolindo. Lombroso perante a Criminologia Contemporânea. São Paulo: Saraiva, 1962.

. Criminosos habituais e por tendência perante o anteprojeto de código penal, de Nélson Hungria. Revista Brasileira de Criminologia e Direito Penal, Rio de Janeiro, v. 1, n. 2, p.133-152, jul./set.1963.

CEREZO MIR, José. Culpabilidad y pena. Anuario de derecho penal y ciencias penales, Madrid, v. 33, n. 2, p.347-365, mai./ago. 1980.

CHAVES CAMARGO, Antonio Luis. Sistema de Penas, Dogmática jurídico-penal e Política Criminal. São Paulo: Universidade de São Paulo, 2001.

COSTA JUNIOR, Paulo José da. Código Penal Comentado. São Paulo: DPJ Editora, 2005.

CUESTA AGUADO, Paz. M. de La. Culpabilidad: exigibilidad y razones para la exculpación. Madrid: Editorial Dykinson, 2003.

DA COSTA, Álvaro Mayrinck. Exame criminológico. São Paulo: Jurídica e Universitária, 1972.

DE CARVAlHO, Amilton Bueno; DE CARVAlHO, Salo. Aplicação da pena $e$ garantismo. Rio de Janeiro: Lumen Juris, 2008.

DE MATTOS, Virgilio. Crimes e psiquiatria. Uma saída. Rio de Janeiro: Revan, 2006.

DEL OMO, Rosa. A América latina e sua Criminologia. Rio de Janeiro: Revan, 2004. 
DEMETRIO CRESPO, Eduardo. Análisis de los critérios de la individualización judicial de la pena en el nuevo codigo penal español de 1995. Anuario de derecho penal y ciencias penales. Madrid, v. 50, único, p. 323-362, jan./dez. 1997.

. Notas sobre la dogmática de la individualización de la pena. Nueva Doctrina Penal, Buenos Aires, p. 19-39, 1998.

DI TULLIO, Benigno. Tratado de Antropologia Criminal. Buenos Aires, 1950.

DIAS, Jorge de Figueiredo. Criminologia. O homem delinquente e a sociedade criminógena. Coimbra: Coimbra, 1997.

Culpa y personalidad: para una reconstrucción ético-jurídica del concepto de culpabilidad en derecho penal. Cuadernos de Política Criminal, Madrid, n. 31, p. 5-38, 1987.

Os Novos Rumos de Politica Criminal e o Direito Penal Português do Futuro. Revista da Ordem dos Advogados, Lisboa, n. 43, p. 5-40, 1983.

Questões fundamentais revisitadas. São Paulo: Revista dos Tribunais, 1999.

. Sobre o modelo de determinação da medida da pena. in Notáveis do direito penal: livro em homenagem ao emérito Professor Doutor René Ariel Dotti. Brasília: Consulex, 2006, p.215-229.

Temas básicos da Doutrina Penal. Coimbra: Coimbra, 2001.

DÍAZ-MAROTO Y VILLAREJO, Julio. Las medidas de seguridad y correción. Actualidad Penal, Madrid, v. 2, 27/48, 1991, p. 450.

DOTTI, René Ariel. Curso de Direito Penal. Parte Geral. São Paulo: Editora Revista dos Tribunais, 2012. 
FEIJOO SÁNCHEZ, Bernardo. Individualización de la pena y teoria de la pena proporcional al hecho. El debate europeo sobre los modelos de derterminación de la pena. Disponível em: www.indret.com. Acesso em: 15/04/2012.

FERRAJOLI, Luigi. Direito e Razão. Teoria do garantismo penal. São Paulo: Revista dos Tribunais, 2006.

FERRI, Enrico; CAPITANIO, Paolo (trad.). Princípios de direito criminal: o criminoso e o crime. Campinas: Bookseller, 1996.

FOUCAULT, Michael. A História da loucura na idade clássica. São Paulo: Perspectiva, 2008.

Os anormais. São Paulo: Martins Fontes, 2010.

FRAGOSO, Heleno Cláudio. Sistema do duplo binário: vida e morte. Revista de Direito Penal. Rio de Janeiro, n. 32, p. 5-21, jul./dez. 1981.

Lições de Direito Penal. Parte Geral. Rio de Janeiro: Forense, 1983.

GOULART, Henny. A individualização da pena no Direito Brasileiro. Dissertação para concurso à livre-docência de Direito Penal da Faculdade de Direito da Universidade de São Paulo. São Paulo, 1970.

GRAMATICA, Filippo. Principios de Defensa Social. Madrid: Montecorvo, 1974. Principios de Derecho Penal Subjetivo. Madrid: Instituto Editorial Reus, 1941.

HERNÁNDEZ, Martín Besio. Los criterios legales y judiciales de individualización de la pena. Valencia: Tirant lo Blanch, 2011. 
HÖRNLE, Tatjana. Determinación de la pena y culpabilidad. Notas sobre la Teoría de la Determinación de la Pena en Alemania. Buenos Aires: Di Placido, 2003.

. La concepción anticuada de la culpabilidad en la jurisprudencia y doctrina tradicionales de la medicón de la pena. Anuario de derecho penal y ciencias penales, Madrid, v. 54, p.401-429, jan./dez. 2001.

HUNGRIA, Nelson. Comentários ao Código Penal. Rio de Janeiro: Forense, 1958.

JIMÉNEZ DE ASÚA, Luis. O estado perigoso. São Paulo: Edições e Publicações Brasil, 1933.

LYRA, Roberto. Comentários ao Código Penal. Rio de Janeiro: Revista Forense, 1955.

MACHADO, Alcântara. Para a história da reforma penal brasileira. Direito. Rio de Janeiro, Editora Freitas Bastos, Ano II, v. 8, mar./abr. 1941, p. 09-42.

MAÍLLO, Alfonso Serrano; PRADO, Luiz Regis (trad.). Introdução à Criminologia. São Paulo: Revista dos Tribunais, 2007.

MANITA, Celina. O conceito de perigosidade. Sub judice. Justiça e sociedade. Coimbra, fasc. 22/23, jul./dez. 2001.

Personalidade criminal e perigosidade: da perigosidade do sujeito criminoso ao(s) perigo(s) de se tornar objecto duma personalidade criminal. Revista do Ministério Público de Lisboa, Lisboa, v. 18, n. 69, p.55-80, jan./mar. 1997.

MARQUES, José Frederico. Tratado de Direito Penal, vol III. Campinas: Millennium Editora, 1999.

MARTÍN, Victor Gómez. El derecho penal del autor: desde la visión criminológica tradicional hasta las actuales propuestas de Derecho penal de varias velocidades. Valencia: Tirant lo Blanch, 2007. 
MARTINSON, Robert. What works? - questions and answers about prison reform. Disponível em: www.nationalaffairs.com. Acesso em: 17/07/2012.

MASSUD, Leonardo. Da Pena e sua fixação: finalidades, circunstâncias judiciais $e$ apontamentos para o fim do minimo legal. São Paulo: DPJ Editora, 2009.

MENDES, Gilmar Ferreira; BOTTINI, Pierpaolo Cruz; PACELLI, Eugenio (coord.). Direito Penal Contemporâneo: questões controvertidas. São Paulo: Editora Saraiva, 2011.

MIRABETE, Julio Fabrini. Manual de Direito Penal. Parte Geral. São Paulo: Editora Atlas, 1985.

NORONHA, E. Magalhães. A classificação de delinquentes no Novo Direito Penal. Revista Brasileira de Criminologia e Direito Penal. Ano IV, $\mathrm{n}^{\circ} .14$, jul./set. 1966, p. 95104.

NUCCI, Guilherme de Souza. Individualização da pena. São Paulo: Revista dos Tribunais, 2009.

PERALTA, José. Elementos subjetivos del ilícito en la determinación de la pena. Anuario de derecho penal y ciencia penales. Madrid, v. 63, Único, p. 251-275, 2011.

PIERANGELI, José Henrique. Códigos Penais do Brasil. Evolução histórica. São Paulo: Revista dos Tribunais, 2001.

PIMENTEL, Manoel Pedro. Breves notas para a história da Criminologia no Brasil. Ciência Penal, Ano V, nº. 2, p. 37-49, 1979.

PRADO, Luiz Regis. Curso de Direito Penal Brasileiro. Volume 1. São Paulo: Editora Revista dos Tribunais, 2006.

Projeto do Codigo Criminal Brasileiro por Alcântara Machado. São Paulo, 1938. 
Projeto de Código Penal Brasileiro. Exposição de Motivos sobre a Parte Geral. Rio de Janeiro: Imprensa Nacional, 1930.

Projeto de Código Penal Brazileiro. Rio de Janeiro: Offs. Grahs. do Jornal do Brasil e da Revista da Semana, 1913.

RAUTER, Cristina. Criminologia e subjetividade no Brasil. Rio de Janeiro: Revan, 2003.

REALE JÚNIOR, Miguel. Instituições de Direito Penal. Rio de Janeiro: Forense, 2009. ... [et al]. Penas e medidas de segurança no novo código. Rio de Janeiro: Forense, 1987. . Tentativa de eliminação do critério da periculosidade. Boletim IBCCRIM, São Paulo, v. 12, 140 Esp, p.2-3, jul. 2004.

RODRIGUES, Anabela Miranda. A determinação da medida da pena privativa de liberdade. Os critérios da culpa e da prevenção. Coimbra: Coimbra, 1995.

ROXIN, Claus. Derecho Penal. Parte General. Madrid: Civitas, 1997. . Estudos de Direito Penal. Tradução de Luís Greco. Rio de Janeiro: Renovar, 2006. Prevención y determinación de la pena. Doctrina Penal: Teoría y prática en las ciencias penales, Buenos Aires, v. 3, 9/12, p.239-263, 1980.

RUIZ, José Ramón Casabó. El fundamento de las medidas de seguridad. Peligrosidad Social y Medidas de Seguridad. Universidad de Valencia, 1974, p. 37-60.

SÁ, Alvino Augusto de. Criminologia clínica e psicologia criminal. São Paulo: Editora Revista dos Tribunais, 2007. 
SANTOS, Juarez Cirino dos. Teoria da pena: fundamentos políticos e aplicação judicial. Curitiba: Lumen Juris, 2005.

SILVA SÁNCHEZ, Jesús María. La teoria de la determinación de la pena como sistema (dogmático): un primer esbozo. Disponível em: www.indret.com. Acesso em 05/05/2011.

TANGERINO, David de Paiva Costa. Culpabilidade. Rio de Janeiro: Elsevier, 2011.

TAVAREZ, Juarez. Culpabilidade e individualização da pena. in Cem anos de reprovação. Uma contribuição transdisciplinar para a crise da culpabilidade. Rio de Janeiro: Revan, 2011.

TOLEDO, Francisco de Assis. Aspectos da aplicação da pena no anteprojeto de Reforma do Código Penal. Ciência Penal. Rio de Janeiro, Forense, Ano VII, n. 1, p. 20-31, 1982.

. Princípios Básicos de Direito Penal. São Paulo: Saraiva, 2010.

ZAFARONI, Eugenio Raul; ALAGIA, Alejandro; SLOKAR, Alejandro. Derecho Penal. Parte General. Buenos Aires: Ediar, 2000.

ZAFARONI, Eugenio Raul. Criminología y psiquiatria: el trauma del primer encuentro. Revista Magister de Direito Penal e Procesual Penal. Ano V, n. 28, p.. 69-85, fev/mar. 2009. . Manual de Direito Penal Brasileiro. São Paulo: Editora Revista dos Tribunais, 2007.

Principio de la Culpabilidad e individualización de la pena. in El nuevo Código Penal: pressupuestos y fundamentos. Granada, 1999. . Tratado de Derecho Penal. Buenos Aires: Ediar, 1995. 
ZIFFER, Patricia S. Consideraciones acerca de la problemática de la individualización de la pena. Derecho penal y criminología, Santa Fé, v. 15, n. 51, p. 44-65, set./dez, 1993.

ZIPF, Heinz. Principios fundamentales de la determinación de la pena. Cuadernos de Política Criminal, Madrid, n. 17, p. 353-359, 1982. 


\section{RESUMO}

A personalidade do agente está relacionada entre os critérios de individualização judicial da pena previstos no artigo 59 do Código Penal brasileiro o qual, tal como muitos outros estatutos repressivos penais, privilegiou algumas das principais ideias defendidas pela Escola da Criminologia Positivista italiana e da Defesa Social.

No curso da história da legislação penal brasileira é possível observar como a subjetividade do réu passou a ganhar importância progressivamente, chegando a tornar-se, em determinado momento, o principal foco de atenção.

Influenciaram esse processo de "subjetivação" da lei penal outros ramos do conhecimento, em especial, a Psicologia, a Psiquiatria e a Antropologia Criminal que, com a irrupção da Ciência Positivista experimentalista acabaram ganharam legitimidade para influenciar diretamente as Ciências Jurídicas, inaugurando, consequentemente, uma nova fase na história do Direito Penal.

Conceitos e institutos típicos dessa fase foram assimilados pela nossa legislação e amplamente defendidos por autores brasileiros do início do século XX. Nossa jurisprudência nacional, da mesma forma, viu-se diretamente influenciada pela tendência subjetivista então inaugurada e assim permanece, em certa medida, até os tempos atuais.

O presente trabalho busca a origem dessas influências, analisa o caminho que ela percorreu em nossa legislação e doutrina penais e visa buscar uma solução garantista e compatível com um Estado Democrático de Direito para o espinhoso problema do critério da personalidade: conceito poroso e de duvidosa possibilidade de aferição.

Para tanto, fundamenta-se nos principais modelos teóricos de determinação da pena que vêm se desenvolvendo na Alemanha e na Espanha com a finalidade de esclarecer qual o papel dogmático dos critérios subjetivos no processo de individualização judicial da sanção. 
Finalmente, procura analisar o conceito de personalidade para a doutrina brasileira e para a jurisprudência, apontando as principais deficiências e dificuldades que este critério acarreta para o operador do Direito, propondo, ao final, uma interpretação possível para aquele conceito. 


\begin{abstract}
The personality of the defendant is listed among the criteria for penalty individualizing provided for article 59 of the Brazilian Penal Code which, like many other repressive penal statutes is focused on some of the main ideas defended by the Italian school of Positivist Criminology and Social protection school.
\end{abstract}

In the course of the history of Brazilian criminal law is possible to observe how the subjectivity of the defendant went on to gain gradually importance, going so far as to become, at given time, the main focus of attention.

Other fields of knowledge, influenced this process of "subjectivation”, in particular, Psychology, Psychiatry and Criminal Anthropology of the criminal law. With the irruption of the Positivist sciences they gained legitimacy to directly influence the legal sciences, inaugurating, consequently, a new phase of criminal law.

Concepts and typical institutes of this phase were assimilated by our legislation and widely advocated by brazilian authors of the early 20th century. Our national case-law, likewise, was directly influenced by the subjectivist trend then opened and remains, to some extent, up to the present time.

The present paper seeks the origin of these influences, analyzes the path that it traveled in our legislation and penal doctrine and aims to seek a solution conformable to a democratic State of law to the thorny problem of the criterion of personality: a porous concept and of doubtful possibility of admeasurement.

To this end, is based on the main theoretical models of penalty determination that have been developing in Germany and in Spain in order to clarify what dogmatic role the subjective criteria play in the process of individualization of judicial sanction. 
Finally, it seeks to analyze the concept of personality to the Brazilian doctrine and jurisprudence, pointing the main shortcomings and difficulties that entails for the law's operators, proposing, at the end, a possible interpretation to that concept. 